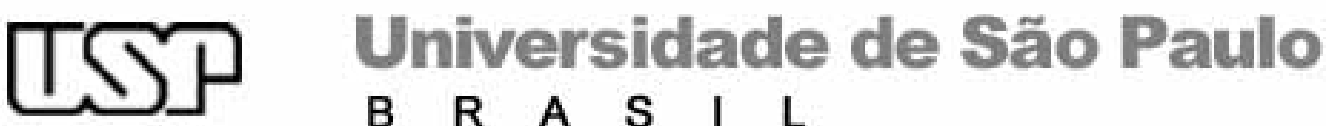

B $\quad$ R $\quad A \quad S \quad I \quad L$

FACULDADE DE FILOSOFIA, LETRAS E CIÊNCIAS HUMANAS DEPARTAMENTO DE LETRAS MODERNAS

PROGRAMA DO CURSO DE PÓS-GRADUAÇÃO DE ESTUDOS LINGÜÍSTICOS E

LITERÁRIOS EM INGLÊS

\title{
A Questão da Avaliação da Aprendizagem de Língua Inglesa Segundo as Teorias de Letramentos
}

\section{Ana Paula Martinez Duboc}

\begin{abstract}
Dissertação apresentada ao Programa de Pós-Graduação em Estudos Lingüísticos e Literários em Inglês, do Departamento de Letras Modernas da Faculdade de Filosofia, Letras e Ciências Humanas da Universidade de São Paulo para obtenção do título de mestre em Letras.
\end{abstract}

São Paulo

2007 


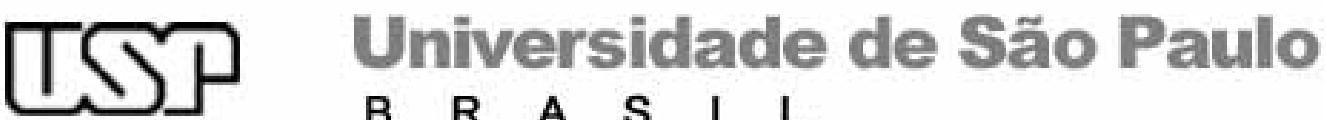

B $R$ A $S$ I L

FACULDADE DE FILOSOFIA, LETRAS E CIÊNCIAS HUMANAS DEPARTAMENTO DE LETRAS MODERNAS

PROGRAMA DO CURSO DE PÓS-GRADUAÇÃO DE ESTUDOS LINGÜÍSTICOS E

LITERÁRIOS EM INGLÊS

\title{
A Questão da Avaliação da Aprendizagem de Língua Inglesa Segundo as Teorias de Letramentos
}

\author{
Ana Paula Martinez Duboc
}

Orientação: Profa. Dra. Walkyria Monte Mór

Dissertação de Mestrado apresentada à Banca Examinadora da Universidade de São Paulo como exigência parcial para obtenção do título de mestre em Letras.

Agência Financiadora: CAPES

São Paulo 
Aos meus pais, Álvaro Salvador Martinez e Veraniz Lucas Martinez, por terem me dado o presente da vida e com ela toda uma trajetória de aprendizados. 


\section{Agradecimentos}

Agradeço à colaboração das professoras participantes da pesquisa, sem a qual o trabalho não poderia ter sido realizado.

Minha gratidão à Profa. Dra. Walkyria Monte Mór, pela excelente orientação, confiança em meu trabalho e por sua paciência e compreensão quanto às mudanças de enfoques e rumos no decorrer da pesquisa.

Agradeço também, aos professores doutores Anna Maria G. Carmagnani e Lynn Mario T. Menezes de Souza pelas preciosas sugestões durante o Exame de Qualificação.

Um agradecimento especial ao meu marido, Nicolai M. Duboc Natal, com quem aprendi que o ensino significativo se faz presente no dia-a-dia, numa relação dialógica constante, possibilitando-nos o crescimento pessoal.

Obrigada, também, aos colegas e funcionários da Área, em especial, às amigas Renata M. Rodrigues Quirino de Sousa, pela ajuda constante, e Taíse Figueira Motta, pelos longos e instigantes diálogos.

Agradeço, ainda, a CAPES, pelo apoio financeiro durante a realização da pesquisa. 
BANCA EXAMINADORA 


\section{Resumo}

Este trabalho apresenta uma investigação sobre as concepções e práticas referentes à avaliação da aprendizagem de língua inglesa em comunidades do Ensino Fundamental. Os registros dessa investigação são aqui analisados e servem como ponto de partida para uma discussão sobre o tema segundo a perspectiva das teorias de letramentos predominantes nas últimas décadas. Trata-se de uma pesquisa qualitativa-interpretativa de caráter etnográfico (André, 2003), cujas perguntas direcionadoras são:

I. Como se caracteriza hoje a avaliação da aprendizagem nas aulas de inglês em algumas comunidades do Ensino Fundamental?

II. Como pensar a concepção de avaliação da aprendizagem de línguas sob a perspectiva dos novos estudos de letramento?

Diante das observações de aulas, das entrevistas com as professoras e da análise dos documentos, pudemos identificar a recorrência de uma concepção de avaliação pautada no paradigma da modernidade, cujos problemas mais evidenciados foram seu entendimento como sinônimo de mensuração, a ênfase ao ensino de conteúdos objetivos e estáveis e ainda a prioridade do uso de provas escritas.

Tais evidências, porém, não se fizeram de modo linear e homogêneo, uma vez que as narrativas e práticas pedagógicas dos sujeitos de pesquisa mostraram-se descontínuas e contraditórias. Assim é que pudemos curiosamente identificar concepções estruturalistas de língua acompanhadas de uma prática avaliativa formativa e concepções progressistas de ensino ao lado de uma concepção convencional de avaliação.

No que diz respeito à discussão da avaliação de línguas diante das transformações epistemológicas assinaladas pelos novos estudos de letramento, concluímos que sua reconceituação deverá abarcar elementos até então negligenciados pela concepção convencional de educação. Trata-se, pois, de uma re-conceituação em curso e que requererá maior expansão de conhecimento por meio de pesquisas acadêmicas.

Palavras-chave: ensino de línguas, avaliação da aprendizagem de línguas, teorias de letramentos, multiletramentos, letramento crítico. 


\begin{abstract}
The aim of this study is to investigate both conceptions and practices regarding English language assessment in some Elementary School communities. The reports of this investigation are then analyzed and serve as a starting point for a discussion about the theme from the perspective of the prevailing new literacy studies in the last decades. It is an interpretative-qualitative research, with ethnographic aspects (André, 2003), whose guiding questions are:
\end{abstract}

I. How does language assessment evolve in English classes in some Elementary School communities?

II. What would the conception of language assessment be like from the perspective of the new literacy studies?

Through research field, interviews with teachers and documentation analysis, we could identify a recurring conception of evaluation based on the paradigm of Modernity, whose most evident problems were its interpretation as measurement, the emphasis on objective and stable contents, and also the predominant use of written assessments.

These findings, however, did not occur in a linear and homogeneous way, since both narratives and teaching practices appeared to be discontinuous and contradictory. Thus, we could curiously notice language structuralist conceptions together with formative evaluation and progressist views of language beside a more conventional evaluation concept.

Regarding the discussion of language assessment towards the epistemological transformations signaled by the new literacy studies, we come to the conclusion that its re-conceptualization should enclose certain elements hitherto neglected by a conventional education conception. This, therefore, refers to a current reconceptualization, which will demand more academic research outcomes.

Key words: language teaching, language assessment, new literacy studies, multiliteracies, critical literacy. 


\section{SUMÁRIO}

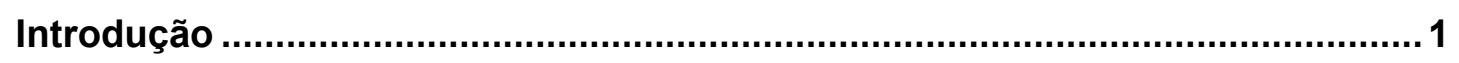

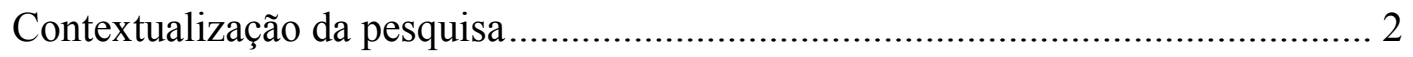

Considerações acerca da escolha metodológica .................................................. 7

Descrição das comunidades........................................................................... 10

1. 0 ensino de língua inglesa: três contextos............................................... 13

1.1 As concepções de língua e a prática pedagógica: descontinuidades ................ 13

1.2 Retratos do modelo neoliberal de educação e o poder de agência ................... 41

2. Problemas da avaliação da aprendizagem no paradigma da modernidade .54

2.1 As bases epistemológicas constituintes da avaliação ..................................... 54

2.1.1 Problema 1: Avaliação como sinônimo de mensuração ............................. 57

2.1.2 Problema 2: A ênfase a conteúdos objetivos e estáveis............................. 63

2.1.3 Problema 3: A prova escrita em seu pedestal .......................................... 69

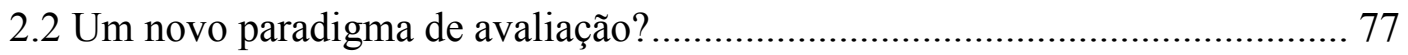

2.3 Avaliação e os modelos de ensino de línguas: outras descontinuidades .......... 83

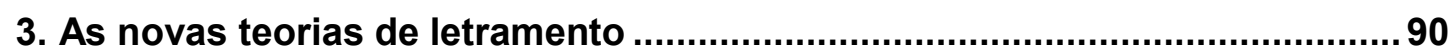

3.1 Uma nova base epistemológica de educação................................................ 90

3.2 Repensar a avaliação sob a perspectiva dos letramentos.............................. 100

3.2.1 A re-significação do conteúdo a ser avaliado ........................................ 102

3.2.2 Características da avaliação segundo os letramentos ............................ 109

3.2.3 Redesenhando algumas modalidades da avaliação ................................ 111

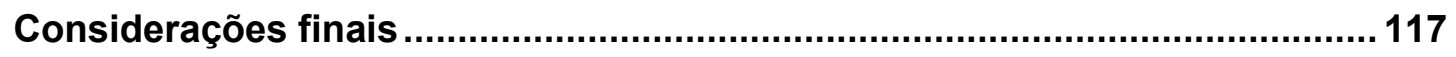

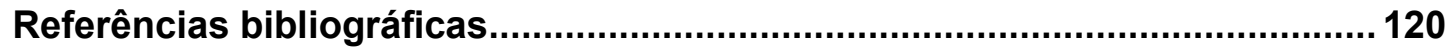

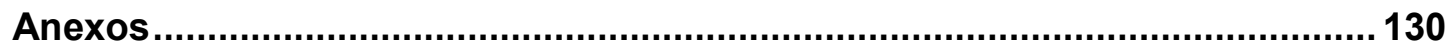

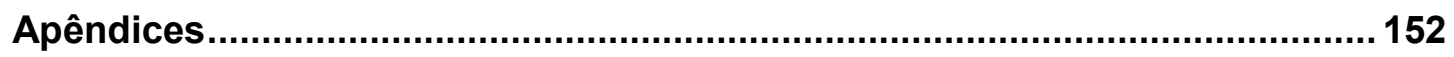




\section{Introdução}

Titã, a cujos olhos imortais

As dores dos mortais

Mostram-se em sua crua realidade,

Como algo que os próprios deuses vêem,

Que prêmio mereceu tua piedade?

Um profundo e silente sofrimento,

O abutre, a corrente, a rocha,

E o orgulho de sofrer sem um lamento.

SHELLEY

No mito da criação do mundo, a decisão de Prometeu, "o ladrão do fogo celestial" nas palavras de Byron, em prol da civilização humana provocou a fúria de Zeus, o qual determinou que o titã tivesse seu fígado eternamente devorado por um abutre. Assim, o que parecia justo, bom ou natural para Prometeu e os homens, a Zeus pareceram atitudes desobedientes e errôneas.

Embora diante de um mito, a história de Prometeu nos convida à difícil tarefa de julgar quem teria agido corretamente e de buscar a compreensão do que vem a constituir o certo e o errado, o justo e o injusto. Trata-se de um momento de avaliação, atividade de grande relevância no processo do desenvolvimento humano na medida em que "saberes, fazeres, regras, normas, proibições, estratégias, crenças, idéias, valores e mitos" perpassam inevitavelmente o homem e a sociedade (Rosati, 2005: 78), donde, tal como afirma a autora (ibidem):

Avaliar-se é perceber-se, identificando-se na história, na leitura do contexto, nas reais necessidades e ter acesso às informações sobre o mundo e à possibilidade de articulálas e organizá-las.

Broadfoot (1996: 03) igualmente assume a avaliação como ação fortemente presente nas relações humanas, situada no cerne da vida social: 
Assessment is a central feature of social life. Passing judgment on people, on things, on ideas, on values is part of the process of making sense of reality and where we stand in any given situation.

Ao assumir a avaliação como atividade cultural e presente nos diferentes contextos sociais, a socióloga faz referência a dois tipos de avaliação: a avaliação informal, que permeia toda e qualquer relação humana; e a avaliação formal, que se caracteriza pela exigência da apresentação de evidências que possam comprovar o julgamento de um determinado evento.

$\mathrm{Na}$ medida em que este trabalho compartilha das idéias de Broadfoot (op.cit.) quando esta confere à avaliação um aspecto central nas relações sociais, investigar seu espaço na educação e principalmente sua re-conceitução diante de propostas pedagógicas contemporâneas torna-se imprescindível.

\section{Contextualização da pesquisa}

A análise que este trabalho julga pertinente diz respeito às conceituações e características da avaliação da aprendizagem de língua inglesa no dia-a-dia escolar, seja ela de natureza formal ou informal, bem como às implicações dessas representações e práticas da avaliação para o próprio processo de ensino e aprendizagem e, ao longo prazo, para a formação do aluno enquanto sujeito inserido numa determinada comunidade.

Compartilhando dessas mesmas preocupações, ainda que situados em outros tempos, muitos trabalhos têm assinalado a cultura de avaliar classificatória e meritocrática na educação básica brasileira, quaisquer que sejam as áreas de conhecimento. Esse "discurso de denúncia" acentuou-se na década de 80 e perpassou toda a década de 90 de forma bastante incisiva dada a relevância com que o tema da avaliação educacional passou a ser tratado (Sousa, 1995). Desde então, diversos trabalhos acadêmicos têm sido publicados com o intuito de desvelar o modus operandis da avaliação escolar, usualmente caracterizado como mecanismo de seleção (Candau e Oswald, 1995), e principalmente oferecer subsídios teórico-metodológicos que possibilitassem a mudança da prática avaliativa. 
A importância com que esta pesquisa trata as questões referentes à avaliação educacional é fruto de minhas próprias experiências profissionais. ${ }^{1}$ Comecei a trabalhar como professora de inglês em 1999, em uma escola de idiomas localizada no município de São Carlos, onde permaneci cinco anos lecionando na própria escola de idiomas, em um colégio particular para o qual a escola de línguas oferecia seus serviços em sistema de terceirização ou parcerias, e ainda em uma das empresas da cidade, em sistema incompany. Os treinamentos pedagógicos oferecidos pela escola em geral priorizavam questões de metodologia de ensino e planejamento de cursos, aulas e atividades, negligenciando, no entanto, o aspecto da avaliação, a qual era sempre tratada no último dia da semana de planejamento, quando grupos de professores se reuniam para elaborar provas escritas, as quais seriam padronizadas e utilizadas ao longo do ano letivo por todos os professores.

Àquela época, posso dizer que não dispunha de discernimento ou consciência quanto ao papel da avaliação na educação. Ao delegarem a responsabilidade de elaborar provas escritas ou temas para avaliações orais, sentia-me entediada e cumpria com meu dever de maneira bastante mecanicista, recorrendo às pastas de modelos de provas. Àquela época, vale ressaltar, minha representação de avaliação ainda estava pautada em mensuração de conhecimentos por meio da aplicação de provas ao longo do período letivo.

Durante o meu processo de formação na graduação em Letras em uma instituição pública, o que ocorreu entre 1997 e 2001, não tive a oportunidade de discutir explicitamente conceitos referentes à avaliação, suas origens, seus diferentes propósitos e as implicações para o ensino e para a sociedade. Somente mais tarde, na condição de professora-substituta na mesma instituição, acabei por questionar os efeitos que tanto o modo de avaliar dos docentes quanto a forma como tratam a questão da avaliação poderiam trazer aos alunos-futuros professores. No que se refere ao curso de Licenciatura, os alunos cursam em geral disciplinas como Didática, Metodologia de

\footnotetext{
${ }^{1}$ Entendemos ser apropriado o uso da $1^{\mathrm{a}}$ pessoa do singular neste trecho por tratar de descrição da trajetória pessoal da pesquisadora.
} 
Ensino, Estágio Supervisionado ou Prática de Ensino, Lingüística Aplicada ${ }^{2}$. Porém, quais disciplinas contemplam a questão da avaliação educacional como importante aspecto do ensino? Que concepções teórico-metodológicas da avaliação da aprendizagem são discutidas e o quão articulado encontra-se este debate com o que se tem produzido nas pesquisas acadêmicas do campo de conhecimento no qual estamos inseridos e ainda com as políticas educacionais implementadas?

É curioso, portanto, notar que meu interesse em avaliação não surgiu de meus primeiros anos de experiência profissional, na escola de idiomas, mas apenas em 2003, quando tive a oportunidade de lecionar em um curso de formação de professores. Assim, naquele mesmo ano, decidi dar início a uma fase de auto-estudo sobre avaliação educacional, com leituras específicas sugeridas por ex-professores da faculdade e cursos de extensão. Ainda àquela época, planejava investigar o tratamento da avaliação em cursos de Licenciatura, pois foi nesta esfera em que me senti instigada a buscar respostas acerca do tema. Mais tarde, porém, as leituras realizadas no programa de PósGraduação em que me inseri bem como a própria necessidade de re-investigar a avaliação na Educação Básica diante de novas bases epistemológicas educacionais deste início do século fizeram-me repensar os rumos antes estabelecidos. Passei, então, a dedicar-me à tarefa de investigar as práticas avaliativas da língua inglesa de determinados contextos do Ensino Básico.

Um leitor que se interesse pelo tema da avaliação e que tenha realizado muitas leituras na área poderá, no entanto, questionar-se: "Mais uma pesquisa sobre avaliação da aprendizagem?" Justifico a opção do tema explicitando que o presente trabalho lança-se à tarefa de não somente investigar a ação avaliativa que perpassa a prática escolar da educação básica per se, assinalada ad nauseum por muitos pesquisadores, mas de promover a investigação articulada com os novos estudos de letramento, buscando sinalizar a importância de re-conceituar a avaliação educacional sob a perspectiva dessas novas teorias no âmbito das pesquisas sobre ensino de línguas estrangeiras.

\footnotetext{
${ }^{2}$ A denominação das disciplinas bem como suas ementas variam entre as instituições de ensino superior, dada a flexibilização do currículo pretendida pelo CNE (Conselho Nacional da Educação), havendo, no entanto, a obrigatoriedade do cumprimento de conteúdos mínimos.
} 
O propósito de promover uma crítica da avaliação da aprendizagem segundo a perspectiva de letramentos justifica-se na medida em que, apesar dos avanços que os estudos em avaliação sofreram ao longo do século $\mathrm{XX}$, sobretudo no que concerne às contribuições do viés sociológico para o campo educacional, as últimas décadas do século XX e o início deste vêm problematizar as diversas facetas da educação justamente por tornarem cada vez mais evidente a emergência de importantes transformações na base epistemológica do conhecimento e, conseqüentemente, de ensino e aprendizagem, de currículo, de pedagogia em termos mais gerais. Tal virada epistemológica requererá, certamente, maior expansão de conhecimento em âmbito acadêmico.

Dessa forma, o lócus de crítica da pesquisadora para a investigação sobre o conceito de avaliação da aprendizagem da língua inglesa constitui as teorias de letramento produzidas desde as últimas décadas do século $\mathrm{XX}$, dentre as quais mencionamos por ora as contribuições de Cope e Kalantzis (2000), Gee (2000, 2004), Lankshear e Knobel (2003) e Soares $(2004,2005)$. Tal lócus reflete o exercício de letramento crítico da própria pesquisadora, uma vez que a análise interpretativa das realidades observadas advém da leitura dos diversos modos de significação disponíveis em seu entorno. ${ }^{3}$

Partindo dessas inquietações, apresentamos as perguntas norteadoras dessa pesquisa:

I) Como se caracteriza hoje a avaliação da aprendizagem nas aulas de inglês em algumas comunidades do Ensino Fundamental?

II) Como pensar a concepção de avaliação da aprendizagem de línguas sob a perspectiva dos novos estudos de letramento?

A fim de contemplar tais perguntas, a dissertação divide-se em três capítulos, nos quais os dados coletados são analisados com base nas fundamentações teóricas que norteiam este trabalho.

\footnotetext{
${ }^{3}$ Trataremos mais detalhadamente desses modos de significação na discussão subseqüente acerca da escolha metodológica.
} 
O primeiro capítulo traz como enfoque a investigação das concepções e práticas de ensino da língua inglesa das participantes da pesquisa. Entendemos que tal análise nos permite delinear o que cada professora entende por língua ou, em termos mais gerais, a base epistemológica de conhecimento na qual se inserem. Ainda neste primeiro capítulo, julgamos pertinente assinalar algumas correlações entre as práticas pedagógicas observadas e o modelo neoliberal de ensino, com enfoque para as manifestações do poder de agência dos sujeitos de pesquisa, considerando, naturalmente, cada fenômeno em seu contexto.

O segundo capítulo busca tecer a análise das concepções e práticas de avaliação dos sujeitos de pesquisa juntamente com algumas considerações teórico-metodológicas, tendo como enfoque as bases epistemológicas que permearam o processo de constituição da avaliação educacional enquanto campo definido e complexo ao longo do século XX (Vianna, 1995). Ao propor tal análise, o capítulo promove a crítica da avaliação da aprendizagem no paradigma da modernidade, ressaltando três problemas recorrentes, a saber, a conceituação da avaliação como sinônimo de mensuração; a ênfase à avaliação de conteúdos objetivos e estáveis; e a priorização da prova escrita dentre as formas avaliativas. Num segundo momento, propomos a discussão sobre avaliação educacional no bojo das teorias ou modelos de ensino de línguas estrangeiras de forma a investigar as regularidades e descontinuidades nas significações e práticas de ensino e avaliação das participantes da pesquisa.

No terceiro capítulo são apresentadas algumas considerações teóricas sobre o conceito de letramento, com ênfase para as novas teorias de letramento emergentes nas últimas décadas do século XX e início deste. O capítulo tem como objetivo discorrer acerca das transformações na base epistemológica do conhecimento e as possíveis implicações para o ensino de língua inglesa, especificamente aquelas voltadas à questão da avaliação da aprendizagem. Assim, são discutidas mudanças quanto ao conteúdo, às características e às modalidades da avaliação na perspectiva das teorias de letramentos, com ênfase para o trabalho de letramento crítico no âmbito das salas de aula de língua inglesa dos contextos observados. 


\section{Considerações acerca da escolha metodológica}

Este estudo caracteriza-se como pesquisa qualitativa interpretativa de caráter etnográfico na medida em que se orienta por fundamentos tipicamente caracterizadores dessa abordagem. Dentre estes, André (2003) destaca a hermenêutica, dado o constante processo de interpretação e compreensão dos significados construídos pelos sujeitos envolvidos na pesquisa; a contextualização; a descoberta em detrimento da constatação e ainda a negação da neutralidade do pesquisador.

O caráter etnográfico é justificado uma vez que o trabalho busca a compreensão do significado de ações ocorridas em uma determinada prática escolar, expressas sob a forma da linguagem verbal ou na própria vivência de determinada ação. Trata-se de uma tentativa de entendimento da lógica que orienta as práticas pedagógicas investigadas, partindo da observação de valores, representações, hábitos e comportamentos dos sujeitos envolvidos.

A justificativa é igualmente posta na medida em que este estudo assume técnicas usualmente associadas à etnografia (ibidem: 28), como a interação entre pesquisador e sujeitos de pesquisa durante o trabalho de campo, a possibilidade de mudança de rumos, a ênfase ao processo e ainda a negação de hipóteses pré-estabelecidas tipicamente desejáveis em pesquisas de caráter positivista. Em lugar da formulação objetiva de hipóteses, há que se reconhecer a ocorrência de algumas expectativas de minha parte inevitavelmente construídas na fase anterior à coleta de dados e durante a pesquisa de campo. Tais expectativas foram ora contempladas, ora negadas, possibilitando interessantes leituras das comunidades observadas tal como revela a análise dos dados nos capítulos subseqüentes.

Justamente por tratar de estudo de caráter etnográfico, esta pesquisa não pretende esboçar generalizações quanto à prática avaliativa ocorrida no Ensino Fundamental. Trata-se, ao contrário, de um olhar sobre determinadas comunidades ou grupos sociais e a expressão natural de seus comportamentos contextualizados (Watson-Gegeo, 1988). Conforme a mesma pesquisadora (ibidem: 576): 
(...) The ethnographer's goal is to provide a description and an interpretive-explanatory account of what people do in a setting (such as a classroom, neighborhood, or community), the outcome of their interactions, and the way they understand what they are doing (the meaning interactions have for them).

No que diz respeito à coleta de dados, esta iniciou-se com a observação de aulas ministradas a $5^{\text {as }}$ séries do Ensino Fundamental em três comunidades distintas, sendo duas instituições privadas e uma instituição pública. O período de coleta de dados nas comunidades da educação básica foi de março de 2005 a novembro do mesmo ano.

Com relação aos instrumentos e técnicas de coleta de dados, priorizamos aqueles que possibilitassem a recorrência das representações dos sujeitos de pesquisa da forma mais natural possível. Assim, essas representações puderam ser apreendidas por meio da observação das aulas em todas as comunidades investigadas, acompanhada de anotações de campo de grande valor para o esclarecimento e enriquecimento de dados advindos de outras técnicas utilizadas.

Concomitante às anotações de campo, utilizamos a gravação em áudio em boa parte das aulas observadas, cujos conteúdos foram transcritos. O motivo que impossibilitou a transcrição de todas as aulas observadas diz respeito à falta de clareza de algumas falas devido às conversas paralelas entre os alunos e às constantes interferências externas, como as atividades extra-classe realizadas por outras turmas.

Um outro instrumento de coleta de dados constitui o uso de entrevistas com as professoras-participantes da pesquisa. Entendemos que esses momentos não se caracterizaram como a entrevista tal como é usualmente utilizada para coleta de dados, uma vez que não houve prévia elaboração de perguntas a serem feitas aos participantes. Ao contrário, as perguntas foram surgindo na medida em que a pesquisadora sentia a necessidade de esclarecer alguma questão elucidada pelos sujeitos. O motivo do uso da entrevista aberta, desprovida de roteiro prévio, está calcado na preocupação em minimizar 'influências', deixando, com isso, as participantes à vontade na organização do pensamento e apresentação de suas idéias. 
Conforme descreve Woods (1996: 57), essa forma de condução das entrevistas, a qual parte da elucidação dos dados por meio de histórias ou narrativas pessoais, torna-se interessante na medida em que reduz a possibilidade de respostas tidas como desejáveis tanto por parte do pesquisador quanto por parte dos próprios participantes da pesquisa. Nesse sentido, procuramos evitar perguntas como "Qual abordagem de ensino você utiliza?" ou "O que é avaliação?", havendo espaço para que os sujeitos de pesquisa pudessem transparecer suas concepções de forma confortável.

Finalmente, no que diz respeito à utilização de documentos, mencionamos as atividades desenvolvidas com os alunos e as avaliações escritas, todas gentilmente cedidas pelas professoras-participantes da pesquisa.

Ao tomarmos como lócus de crítica as teorias de letramentos emergentes nas últimas décadas, os próprios dados coletados para a pesquisa podem ser entendidos como modos de significação, juntamente com outros modos representacionais que vão além da linguagem escrita, tais como a forma visual, a espacial e a gestual (Cope e Kalantzis, 2000: 203). Isso porque a análise dos dados coletados nas escolas não se reduz às formas lingüísticas de significação, como as anotações de campo e as entrevistas, mas se constitui diante de uma leitura mais ampla que considera outros modos de produção de sentidos, como o espaço geográfico das escolas, o posicionamento dos sujeitos e suas formas de negociação de sentidos, os diferentes tons de voz utilizados, os olhares, os sorrisos, os gestos e outras formas passíveis de construção de significados. Sob essa ótica, a pesquisa faz ressoar o próprio trabalho de letramento crítico da pesquisadora em seu contato com um conjunto multimodal de significação para além da forma lingüística.

A utilização variada de instrumentos de coleta de dados não deixa de suscitar, porém, a questão da validade e da credibilidade das análises, cuja objetividade constitui-se muito desejável em pesquisas de viés positivista. Ao situarmos esta pesquisa diante do paradigma da pós-modernidade, recorremos à re-conceituação de validade apresentada por Esteban (2003: 187), que, ao tratar das investigações qualitativas em educação, corrobora nossa concepção de conhecimento, de interpretação, portanto, de pesquisa: 
En el amplio ámbito de la investigación cualitativa, el significado tradicional del concepto de validez ha sido reformulado, fundamentalmente, en términos de construcción social del conocimiento, otorgando un nuevo énfasis a la interpretación. ${ }^{4}$

\section{Descrição das comunidades}

\section{Comunidade 1: Colégio Teorema ${ }^{5}$}

Trata-se de uma instituição privada de ensino básico, compreendendo a Educação Infantil, o Ensino Fundamental e mais recentemente o Ensino Médio. O colégio localiza-se na Zona Sul desta cidade, em bairro caracterizado de classe média. De pequeno porte, o colégio foi inaugurado em 1994, atendendo hoje a aproximadamente 500 alunos. Com relação à sua infra-estrutura, o colégio ocupa uma antiga residência, donde se observam inúmeras adaptações de cômodos. O colégio também se utiliza de um outro espaço localizado na mesma quadra a fim de atender a demanda de alunos.

Como proposta pedagógica, o colégio Teorema propõe o ensino qualificado, por meio do qual "todo aluno é tratado como um ser único, respeitando-se todas as suas características e qualidades ${ }^{6}$." A investigação acerca da concepção de educação do colégio suscitou uma questão: até que ponto é possível identificar a sua própria concepção de educação? Isso porque o colégio, a exemplo do que vem ocorrendo em muitos outros contextos, adota um método de ensino apostilado (doravante sistema Homo Sapiens de ensino), colocando-se na condição de escola-parceira. Nesse sentido, buscar a concepção de educação do colégio implica a investigação dos princípios norteadores do sistema Homo Sapiens.

A professora de inglês do colégio Teorema (doravante referida com pseudônimo Aida) é jovem e trabalha como educadora há onze anos. Inicialmente, lecionava aulas na Educação Infantil e, quando concluiu o curso de graduação em Letras, há oito anos, começou a lecionar língua inglesa. Trabalha neste colégio há três anos, onde hoje assume todas as turmas dos Ensinos Fundamental e Médio.

\footnotetext{
${ }^{4}$ Grifos originais da própria autora.

${ }^{5}$ Todos os nomes das comunidades e dos sujeitos de pesquisa constituem pseudônimos.

${ }^{6}$ De acordo com a proposta pedagógica exposta no site do colégio (acesso em 01.06.2006)
} 
A observação das aulas nesse colégio ocorreu entre os meses de março e junho de 2005. Foram observadas oito aulas ministradas a um grupo de quinta série do Ensino Fundamental, além da entrevista com a professora.

\section{Comunidade 2: Colégio Áureo}

A segunda comunidade também se caracteriza como uma instituição privada de ensino, abrangendo igualmente os três níveis escolares: Educação Infantil, Ensino Fundamental e Ensino Médio. Localiza-se na Zona Sul da cidade de São Paulo e atende alunos moradores de bairros próximos, tipicamente considerados de classe média. Embora igualmente considerado de pequeno porte, trata-se de um colégio um pouco maior, cuja infra-estrutura compreende diversas salas de aulas, sala de informática, quadra poliesportiva, biblioteca, piscina e um pátio amplo e agradável.

O colégio Áureo direciona sua proposta pedagógica objetivando: "o equilíbrio e a seqüência de uma aprendizagem constante; a integração de alunos, profissionais e familiares; e o bem-estar e a segurança nos aspectos físicos." Para o Ensino Médio, a ênfase é posta na preparação do indivíduo para enfrentar os desafios da vida profisssional de forma consciente e atuante. A exemplo do colégio anteriormente descrito, também se caracteriza como escola-parceira do sistema Homo Sapiens .

Bastante comunicativa, a professora do colégio Áureo, doravante Sofia, cursou Tradução e Intérprete em uma instituição particular e logo após ingressou no curso de Letras numa outra instituição também particular. No início de sua carreira trabalhou em uma escola pública e hoje leciona inglês em dois colégios particulares, assumindo um total de vinte e uma turmas. Também já trabalhou em escolas de idiomas.

A observação das aulas ocorreu em duas etapas em virtude de algumas contingências pessoais. Assim, a coleta de dados ocorreu nos meses de abril e maio, tendo sido finalizada no mês de novembro. Ao todo, foram observadas 12 aulas ministradas a alunos da quinta série do Ensino Fundamental, além da entrevista com a professora. 


\section{Comunidade 3: EMEF}

A terceira comunidade é a única instituição pública observada. Trata-se de uma EMEF, Escola Municipal de Ensino Fundamental, localizada na Zona Oeste de São Paulo em bairro também caracterizado de classe média. Inaugurada em 1967, a escola é pequena, pois atende aproximadamente 1.000 alunos num total de 10 turmas, sendo que no período noturno os cursos são supletivos. Embora localizada em bairro tipicamente de classe média, boa parte das crianças e pré-adolescentes assistidas pela escola são moradores de favelas e outros bairros próximos.

Com relação à infra-estrutura e organização do espaço físico da escola, chamou-nos a atenção a forma como os educadores dessa comunidade parecem explorar os ambientes externos comuns. O amplo saguão da escola que funciona como refeitório continha exposições de trabalhos dos alunos, os quais eram constantemente atualizados. As atividades expostas demonstravam, em nossa leitura, um cuidado tanto com relação à forma, elaborados com riqueza de materiais, quanto com relação ao conteúdo, voltados a questões de cidadania, como reciclagem, violência e até questões de identidade cultural.

Diferentemente das demais, a professora da EMEF, de pseudônimo Beatriz, é a única profissional cuja formação deu-se numa instituição pública de ensino. Beatriz formou-se em Letras e hoje atua como professora titular de inglês nesta EMEF há quatorze anos. Além desse cargo, também é diretora de ensino de uma outra escola pública desde o ano de 2002, função que considera bastante difícil por envolver muitas responsabilidades. 


\section{0 ensino de língua inglesa: três contextos}

Todo signo (...) resulta de um consenso entre indivíduos socialmente organizados no decorrer de um processo de interação.

BAKHTIN (2004)

\subsection{As concepções de língua e a prática pedagógica: descontinuidades}

Ao considerarmos as três realidades investigadas, as falas de Aida, Sofia e Beatriz são muito reveladoras, havendo espaço para afirmação de uma certa regularidade entre os contextos observados e, contraditoriamente, a uma interessante descontinuidade tanto em suas narrativas quanto em suas práticas pedagógicas. Assim, ao apresentar, de um lado, a investigação acerca do entendimento dos sujeitos de pesquisa quanto ao conceito de língua, e de outro, a análise das ações pedagógicas que praticam na sala de aula, consideramos a possibilidade de discrepâncias, dado o caráter inerente das contradições e descontinuidades em quaisquer práticas sociais (Lyotard apud Tripp, 1992).

Em termos gerais, a interpretação acerca do que as participantes da pesquisa entendem por língua é fruto da análise dos dados coletados por meio das diferentes técnicas utilizadas. Dessa visão do macro, em que uma determinada técnica de coleta de dados vem corroborar a análise construída sobre uma outra, podemos, então, apresentar nossa interpretação como uma das possíveis leituras das realidades observadas.

A relevância da articulação de dados advindos de categorias ou técnicas de coleta diferentes pode ser justificada, por exemplo, da dificuldade inicialmente posta quando buscávamos investigar o que Aida entende por língua. Isso porque durante a entrevista, a professora pareceu não se posicionar de maneira tão clara e explícita quanto ao seu próprio entendimento de língua, relatando de forma bastante objetiva o modelo de ensino adotado pela escola. Esse relato é construído em tom de lamentação, o que nos leva a interpretar sua própria percepção: 
Aida: (...) a proposta é efetivamente é GRAMATICAL... não é muito de pronúncia, né? A [parte de conversação] não trabalho com isso não... mesmo porque são muitos alunos na sala e esse trabalho fica meio complicado de ta fazendo... uma coisa ou outra dá pra fazer... um listening:: um ditado:: vai/eu coloco alguns números mas isso aí é MUITO de vez em quando porque senão eu não consigo cumprir a apostila...

Partindo da transcrição de uma de suas aulas, torna-se possível identificar com maior clareza sua concepção de língua:

Aida: Vai...Vamos lá. Agora antes daquele exercício... então, vocês estão acostumados, estão MUITO acostumados a fazer aquela troca ali, né? You are... Are you. He is... Is he. Né? Só que acontece que agora vocês estão vendo casos com mais pessoas... frases mais longas. E não tem somente o pronome e verbo to be, agora tem nome e o verbo to be, não é? Então tá, eu vou dar umas dicas pra vocês. Quando a frase for muito longa... e vocês tiverem dúvidas...de como substituir os nomes e o pronome então vocês vão a primeira coisa procurar o verbo to be na frase. Por exemplo, olha só:

((Aida escreve na lousa)): Mariana's father is forty years old.

Aida: Agora, prestem atenção, onde está o verbo to be nessa frase? Vocês têm que lembrar que no verbo to be eu tenho "am", "is", ou...?

$\mathrm{As}^{7}$ : are.

Aida: Tá... onde está?

As: is.

Aida: Então tá... na interrogativa o verbo to be não tem que vir antes do nome ou do pronome? Então onde vocês vão colocar?

As: Antes do "Mariana."

Aida: Isso... aqui... Depois o que que sobrou pra copiar?

As: [Mariana's father... forty years old]. ((alguns alunos lêem a frase toda, incluindo o verbo "is")):

Aida: Exatamente. Copia o "is"... Não, olha só, faz de conta que você tirou o "is" daqui e colocou aqui. Só que ficou um buraco, certo?

A: Ah, tá

Aida: Então você vai colocar o resto. ((Aida escreve forma interrogativa na lousa)).Só tomem cuidado para não copiarem o verbo to be duas vezes.

A prática pedagógica de Aida parece revelar o conceito de língua como um sistema fechado de regras, uma vez que a professora prioriza o funcionamento das estruturas gramaticais em seu sentido fixo e estável, o que a possibilita afirmar máximas como "na interrogativa o verbo to be vem antes do nome ou do pronome". Além disso, as enunciações não são tratadas de forma circunstancial, mas de maneira desarticulada e, muitas vezes, mecanicista (Copia o “is”... Não, olha só, faz de conta que você tirou o

\footnotetext{
${ }^{7}$ As $=$ alunos(as)
} 
"is" daqui e colocou aqui. Só que ficou um buraco, certo? Então você vai colocar o resto. Só tomem cuidado para não copiarem o verbo to be duas vezes).

No que diz respeito aos sentidos das frases, estes parecem vir prontos, pré-definidos aos alunos, não havendo espaço para construção de outras significações. A falta de contextualização com que a língua é utilizada é melhor evidenciada no trecho que se segue:

Aida: Então vamos lá. Então vamos fazer uma recapitulação aí. Como é que ficou a primeira "a"? Rita Lee is American.

As: Rita Lee is not American. She is Brazilian. ${ }^{8}$

Aida: Tá. Se:: por um acaso:: na prova:: ou em qualquer situação vocês não quiserem...tirar o nome da Rita Lee e colocarem:: "she" né, você vai tirar e substituir por pronome, vocês podem deixar "Rita Lee" mesmo.

A: Pode colocar Rita Lee tanãnã... Rita Lee is Brazilian?

Aida: Pode... tá? Mas é claro que você vai ter que substituir. Agora se alguém não conseguir, pode usar o nome que fica certo também. (...)"b". Antonio Banderas is from Mexico.

As: Antonio Banderas is not from Mexico. He is Australian

Aida: Certo. "c". That car is an Ômega.

As: [That car is not an Ômega. It is an...]

A interrompe [NOSSA, it is...? A..???]

As: [Vectra].

Aida: Por quê "a"?

As: [Porque...]

Aida: Porque "Ômega" começa com vogal e "Vectra" começa com consoante, então a gente tem que mudar... ele fica ... ele era "an" ele fica? "a" (...) You are my best student.

As: You aren't my best student. You are my best friend.

A: Como é que fica o final?

Aida: you...are...my...best...friend. (...) Pronto? (...) My favorite sport is tennis.

As: [My favorite sport is not tennis. It's judo].

Embora um pouco extenso, o trecho acima é bastante representativo e corrobora nossa interpretação da concepção de língua de Aida como um sistema lingüístico, cujo domínio de estruturas gramaticais parece garantir o aprendizado da língua. $\mathrm{O}$ enfoque à estrutura lingüística e o tratamento negligenciado dos sentidos é igualmente posto se considerarmos o fato de que Antonio Banderas não é australiano, tal como a apostila solicita que os alunos afirmem. Convém, mais uma vez, notar que o espanto de um dos

\footnotetext{
${ }^{8}$ São nossos os negritos presentes nos trechos das falas das professoras.
} 
alunos no decorrer da aula (NOSSA...) se dá em função do uso "incorreto" do artigo indefinido 'an' preposto ao substantivo 'Vectra", e não em função da informação incorreta da professora acerca do ator espanhol, o que constitui mais uma evidência da ênfase à estrutura lingüística e seu tratamento abstrato: balbucia-se qualquer coisa, qualquer nome, desde que a estrutura seja utilizada conforme as regras da língua.

Além dos trechos transcritos das aulas, as provas escritas desenvolvidas por Aida corroboram nossa análise, na medida em que nos deparamos com a ênfase aos aspectos estruturais e lexicais da língua, conforme o Anexo 4, o Anexo 5 e o Anexo 6. No Anexo 4, por exemplo, o primeiro exercício (Figura 1) corrobora a primazia da univocidade de sentidos, uma vez que aos alunos é solicitada a elaboração de um diálogo de forma a continuar as orações pré-planejadas; com isso, ao lerem as palavras “What's ?", espera-se que completem o restante da oração com "your name", não havendo espaço para a criação de outras formas igualmente possíveis:

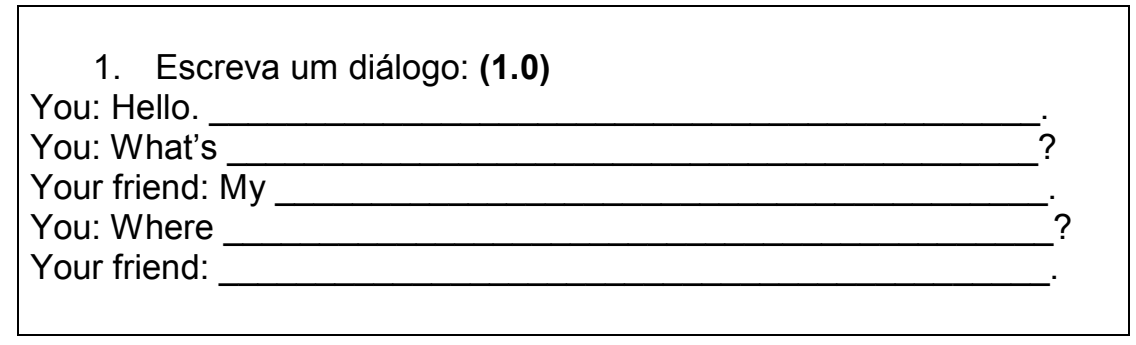

Figura 1: exercício de elaboração de um diálogo, extraído do Anexo 4

Outros exercícios da mesma prova evidenciam o uso da língua como código fixo e abstrato, a exemplo do quarto exercício "Passe as frases para as formas negativa e interrogativa" (vide Anexo 4), em que na frase Carol is my neighbor, o aluno deve negá-la mesmo que de fato possa vir a ter uma vizinha que se chama Carol e ao mesmo tempo interrogar-se, embora se acredite consciente o bastante parecendo-lhe um tanto inusitado formular perguntas a si próprio como "Is Carol my neighbor?". Não que sejamos contrários a divagações pessoais, sempre passíveis de ocorrência; queremos apenas evidenciar o tratamento abstrato da língua nesse contexto específico.

A mesma fixidez e abstração com que Aida trata a língua inglesa pode ser encontrada em boa parte dos exercícios do Anexo 5, cujo objetivo parece ser a testagem do 
conhecimento dos alunos quanto ao uso correto do verbo To $B e$, como mostra o exercício 1 (Figura 2):

1. Faça frases negativas e depois corrija-as utilizando as palavras entre parênteses. Siga o exemplo. (1.0)

Ex. Ronaldinho is a tennis player. (soccer player)

Ronaldinho is not a tennis player. He is a soccer player.

a-) Rita Lee is American. (Brazilian)

b-) Antonio Bandera is from Mexico. (Spain)

c-) My favorite sport is tennis. (football)

d-) Fernando is Beto's uncle. (father)

Figura 2: exercício de elaboração de frases negativas, extraído do Anexo 5.

Convém ressaltar a preocupação de Aida nesse exercício quanto à contextualização de alguns dos itens, como é o caso do próprio exemplo e das frases "a" e "b", na medida em que a professora decide utilizar pessoas reais (Ronaldinho, Rita Lee e Antonio Banderas). Resta saber, entretanto, se os alunos estão familiarizados com Antonio Banderas ou mesmo com Rita Lee, pois essa contextualização reduz-se ao texto em si, não havendo relações entre o que é dito nesses enunciados e o que os alunos têm a dizer sobre eles. Embora reduzidos ao texto, não deixam de constituir enunciados mais adequados do que os demais.

O mesmo tratamento abstrato da língua no exercício acima é ainda presente em outros exercícios da mesma prova, em que a professora utiliza elementos dêiticos (em negrito) em enunciados isolados, sem remeter a qualquer situação comunicativa, com o objetivo apenas de verificar o uso correto de pronomes, como no exercício 6 (Figura 3):

6. Complete as frases com HIS ou HER. (1.0)

a-) Here is Fábio with ___ computer.

b-) This is Mariana with ___ friend.

c-) This is Fernando with son.

d-) Here is Marcia with __ husband

Figura 3: exercício gramatical, com ênfase ao uso de pronomes possessivos, extraído do Anexo 5. 
No que diz respeito ao Anexo 6, a concepção de língua de Aida como código fixo pode ser evidenciada, por exemplo, num exercício (Figura 4) bastante interessante e que transcrevemos logo abaixo:

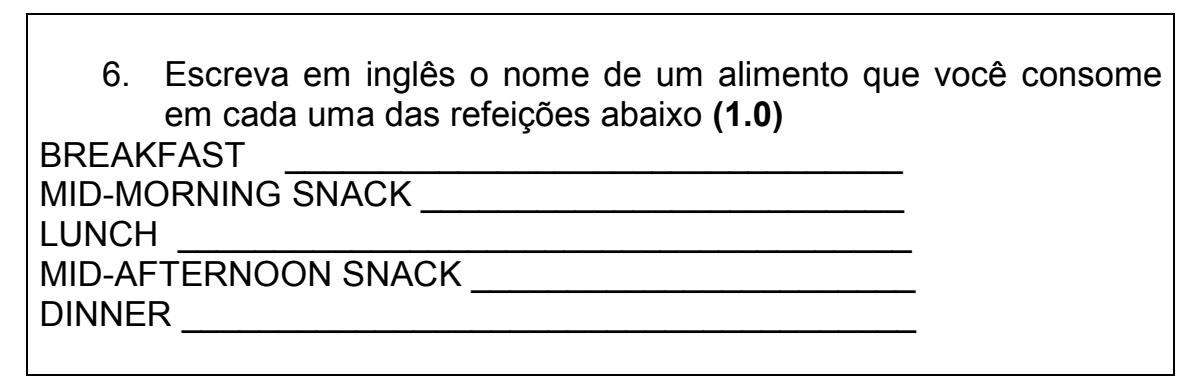

Figura 4: exercício de vocabulário referente às refeições, extraído do Anexo 6.

A pesquisa não assume como objetivo investigar a forma de correção das professoras, priorizando, por ora, a identificação de suas concepções de língua e avaliação; mas não podemos deixar de imaginar com quais critérios Aida corrigiu as respostas dos alunos na medida em que ela fixa o sentido das refeições diante de uma possível categorização dos alimentos.

Questionamos, no entanto, a generalização com que as refeições são tratadas se tomarmos como condição essencial a contextualização e o uso situado da linguagem para a produção dos significados. E se um aluno, hipoteticamente, colocasse como resposta para "breakfast", a palavra "rice"? Essa resposta causaria estranhamento em Aida ou ela a consideraria correta? Tratar-se-ia, naturalmente, de hábito pouco usual no Brasil, mas muito comum na cultura japonesa, por exemplo, o que nos faz questionar o caráter estanque atribuído aos significados das refeições referidas pela professora.

Essa fixidez com que os conceitos são tratados decorre, em termos gerais, da influência do paradigma da modernidade, cujo ideal de totalidade e busca do conhecimento do real acabam por engessar variações lingüísticas e culturais que não estejam de acordo com a variação dominante:

No interior do discurso do modernismo, o conhecimento desenha suas fronteiras quase que exclusivamente a partir de um modelo europeu de cultura e civilização.

(Giroux, 1993: 42) 
Corroborando as palavras de Giroux (op.cit.), a noção de breakfast tal como posta no exercício de Aida refere-se a um conceito europeu transferido a outros povos durante o processo de colonização. A idéia das refeições (meals) estabelecidas cada qual em seu horário também o é, o que acaba por padronizar os usos e os costumes nos diferentes países colonizados.

Em contrapartida às limitações do discurso totalizante da modernidade, os estudos da pós-modernidade vêm problematizar a questão na medida em que começam a privilegiar questões como a diversidade, a localidade, a especificidade e o contingente (Giroux, ibidem) instigando-nos a repensar algumas práticas escolares à luz de tais diferenças.

Das contribuições mais recentes advindas especificamente dos teóricos dos letramentos, Cope e Kalantzis (2000: 14) afirmam a relevância da diversidade lingüística e cultural e a necessidade de uma nova pedagogia que possa ensinar os alunos a negociarem os sentidos da linguagem, outrora fixados, incluindo a habilidade de lidar com as variações lingüísticas regionais, étnicas ou de classe, bem como as variações de registro formal ou informal nos diferentes contextos.

Assim, um trabalho de letramento crítico desenvolvido a partir desse exercício poderia, por exemplo, incluir a discussão com os alunos sobre o que vem a constituir breakfast em diferentes países ou até mesmo em diferentes regiões de um mesmo país, oferecendo-lhes a possibilidade de criar significados com maior mobilidade diante das diferenças culturais e, conseqüentemente, contradizendo qualquer tentativa de fixação de sentidos.

No que tange especificamente ao conceito de língua como um código lingüístico fixo predominante no contexto de ensino de línguas, podemos dizer que este é decorrente da influência dos estudos estruturalistas do início do século XX. Ao ser tomada como objeto de estudo por lingüistas estruturalistas como Saussure (1916), a língua é caracterizada como sistema de signos cujos significados já são pré-determinados por convenção social, não havendo possibilidade de interpretação aos sujeitos-usuários. $\mathrm{O}$ 
próprio Saussure (1999: 83) ${ }^{9}$, ao relativizar o conceito da arbitrariedade do signo, afirma que " $n \tilde{a} o$ está ao alcance do individuo trocar coisa alguma num signo, uma vez esteja ele estabelecido num grupo lingüístico". Trata-se, portanto, de um conceito de língua inserido no paradigma positivista, dada a ênfase à objetividade do objeto de estudo, no caso a língua, bem como à análise isolada de suas partes (Fidalgo, 2002: 22).

Tendo como lócus de enunciação uma abordagem marxista da linguagem, Costa (2000: 28) promove a crítica ao caráter isolado e abstrato conferido à língua pela Lingüística enquanto ciência compartimentada:

No campo da investigação lingüistica tradicional (...) o aspecto lingüístico é abstraído da totalidade das relações sociais e, para estudá-lo, é criada uma disciplina própria, um departamento estanque e autônomo do conhecimento humano.

Nesse sentido, o autor assume um outro conceito de língua que considera a linguagem como fenômeno social, donde o processo de significação é fruto das práticas sociais situadas num determinado contexto (ibidem: 38). Ao negar, portanto, a concepção de língua como sistema de signos fechado e abstrato, Costa busca respaldo nas contribuições dos estudos bakhtinianos para caracterizar o fenômeno lingüístico partindo da relação indissociável entre as dimensões social, laborativa, interativa, ideológica e histórica (ibidem: 51) - a nosso ver, uma concepção mais ampla e interessante do que a visão estruturalista de língua.

A conceituação de língua de Aida como um código lingüístico definido por regras pôde ser também observada no contexto da EMEF. Ao descrever algumas das atividades que desenvolve com seus alunos, Beatriz acaba por revelar seu entendimento de língua como sistema fechado em si mesmo, cuja aprendizagem é garantida por meio do domínio das estruturas gramaticais:

Beatriz: por exemplo eu to trabalhando agora com perguntas e respostas... que é uma coisa DIFÍCIL pro estudante entender principalmente por causa do verbo auxiliar... olha já faz mais de um mês que eu to com esse verbo auxiliar e eles não entendem...porque é uma coisa que não existe em

\footnotetext{
${ }^{9}$ O Cours de Linguistique Generale é obra póstuma. A primeira publicação ocorreu em 1916, chegando ao Brasil com mais de 50 anos de atraso.
} 
língua portuguesa né? mas perguntar e responder todo mundo fica perguntando toda hora... se você pergunta em português eles não têm problema nenhum/agora se começa tentar fazer a correspondência na tradução:: eles se perdem no verbo auxiliar... aí eu fico mostrando que não tem como traduzir... eu ponho a tradução na lousa eu ponho a flechinha/essa palavra é essa palavra... essa é essa... pra mostrar... ah...aí eles vão entendendo... tem alguns que já aprenderam já estão adiante... mas uns que ficam só brincando não tá conseguindo acompanhar...

A própria definição do programa no início do ano letivo denota a ênfase ao ensino da gramática, especificamente ao ensino de tempos verbais, os quais funcionam como uma espécie de guia para a definição dos assuntos trabalhados em sala de aula:

Beatriz: nós decidimos em conjunto aqui na escola... o que nós achamos mais convenientes estar passando pros alunos.. eu faço assim uma programação de tempos BÁSICOS pra quinta:: sexta:: sétima e oitava... então em conjunto com essa professora de inglês a gente dividiu o que era mais interessante ta passando...então na sexta série pra avaliar o presente simples... tudo o que é possível com o tempo presente... então profissões:: trabalho:: as várias situações... nós fizemos o personagem misterioso:: eu mostrei a figura do Garfield:: e eles tinham que (montar) uma série de frases que eram pra descobrir que o personagem era 0 Garfield... eh... dorme de manhã:: come lasanha... mora na casa do John... detesta a segunda-feira... então nós lemos as frases:: traduzimos:: e aí eles concluíram que o personagem era o Garfield aí eu mostrei a figura... olha o Garfield aqui... tudo presente simples... aí fiz com outros personagens... do Batman:: do Super-Homem... é... o conteúdo a gente que define... a gente escolhe o tempo verbal e vamos trabalhando o que pode causar interesse pra eles né...

Além da prioridade ao ensino de regras gramaticais, as atividades descritas por Beatriz também relevam a ênfase ao aspecto lexical da língua, como podemos notar no trecho seguinte:

Beatriz: essa era pra sexta série também...no primeiro semestre eu trabalhei com a sexta série o jogo da memória... essa sexta série A... era um trabalho em grupo... pega uma cartolina e centímetros e eles tinham que colocar o objeto com uma cor... então por exemplo uma laranja:: uma maçã:: e colorir... no outro quadradinho eles tinham que escrever a cor e o nome do objeto... pra usar a inversão do adjetivo em relação ao substantivo... red apple... por exemplo... maça vermelha... black cat... gato preto... então a gente já tinha um (certo) vocabulário... e aí ou desenhava ou achava as figuras...e depois tinha que escrever em inglês o que que representava aquela figura por cor... e aí era um jogo da memória... eles embaralhavam e jogavam... leva quatro aulas... confecção e depois jogar... o mais difícil é 
lembrarem de trazer o material... aí pede socorro lá na secretaria/você pode me arrumar umas cartolinas?

Enquanto descreve as atividades que desenvolve com seus alunos, Beatriz também transparece posicionamentos contrários ao que eventualmente vê acontecer em seu entorno, no caso, a habitual prova sem consulta aplicada por seus colegas, para em seguida justificar sua prática:

Beatriz: tem alguns que dão prova sem consulta... eu acredito que sem consulta não adianta nada porque se ele vai memorizar ele vai esquecer....eu não quero que ele memorize/eu quero que ele SAIBA fazer... por exemplo eu faço uma palavra cruzada pra eles fazerem do dia das bruxas... nós estudamos o vocabulário primeiro... as palavras... eu mostro umas fichinhas de cartolina com uns desenhos e vou falando o nome de cada um dos personagens... depois que falamos eles vão anotar as palavras... nós vamos escrever as palavras... aí nós vamos ler o que eles escreveram... porque muitos copiam errado também.. porque muitos da $6^{\text {a }}$ série não têm uma alfabetização muito consolidada:: e só na cópia eles já cometem erros...

Do excerto acima, podemos inferir que, para Beatriz, a aplicação de provas sem consulta implica memorização de conteúdos em detrimento de uma aprendizagem significativa, a qual constitui, na visão da professora, a utilização do conhecimento para agir em um determinado contexto (tem alguns que dão prova sem consulta... eu acredito que sem consulta não adianta nada porque se ele vai memorizar ele vai esquecer...eu não quero que ele memorize/eu quero que ele SAIBA fazer...).

Segundo Sousa (2006: 14), a memorização de conteúdos constitui um mecanismo bastante recorrente na pedagogia tecnicista dos anos 60 e ressoante no atual modelo neoliberal de educação, tendo como propósito atender as exigências do mercado de trabalho e dos exames para ingresso nas escolas superiores.

Bastante pesquisada pela psicologia cognitiva em décadas anteriores, a questão da memória e sua relação com o processo de aprendizagem tem recebido diversas críticas, conforme inferimos de Smith (1993: 196, 200):

The world, society, individuals, and especially brains and bodies are widely perceived in terms of computers as systems that feed off information. The current paradigm in cognitive psychology regards the brain as a repository of information, thought as 
'information processing', and learning as the mechanism by which new information is acquired. (...) The brain is not a repository of information like a library or the memory banks of a computer.

Na medida em que Beatriz opõe o processo de memorização ao "saber fazer", parecenos que seu conceito de memória refere-se ao acúmulo de informações sem qualquer comprometimento com o significado enquanto que o "saber fazer" constituiria nossa capacidade de interpretação e criação de sentidos de que trata Smith (ibidem: 198). Assim, o autor (ibidem: 203) assume o aprendizado como aquele significativamente produzido nas interações diárias dos sujeitos com o mundo, o "saber fazer" de Beatriz, em contrapartida à ineficiência da memorização:

Rote learning - the deliberate effort to memorize unrelated items of information - is so difficult and inefficient as to be clearly unnatural, the brain's least preferred way of learning.

Ao voltarmos para a concepção de língua de Beatriz como sistema lingüístico fechado, recorremos também às atividades propostas aos alunos (vide Anexo 1, Anexo 2 e Anexo 3). No Anexo 1, por exemplo, a professora apresenta, num primeiro momento, a tradução isolada e descontextualizada de vocábulos, os quais devem ser usados para a compreensão das orações da segunda folha. Há ainda uma terceira etapa da atividade em que os alunos devem traduzir, dessa vez, toda a frase. O Anexo 2 evidencia a mesma ênfase ao caráter fixo e estável dos conteúdos na medida em que os alunos devem traduzir um pequeno texto intitulado "My pet" recorrendo ao auxílio da tradução dos termos isolados.

A representação de texto da professora igualmente corrobora sua conceituação de língua como sistema de signos estáveis. Isso porque a professora parece priorizar atividades que visam a aquisição de vocabulário em língua inglesa. Em termos procedimentais, as atividades propostas por Beatriz como o uso da tradução (vide anexos) parecem fragmentar o texto em frases e, num segundo estágio, as frases em vocábulos, cujos sentidos devem ser devidamente atribuídos e anotados pelos alunos em seus cadernos. 
Considerando os excertos das entrevistas e das aulas, podemos dizer que a prática pedagógica de Beatriz, tal como a de Aida, prioriza o ensino de conteúdos, aqui caracterizados pela aprendizagem de gramática e de vocabulário da língua inglesa, e que culmina na transmissão de conhecimentos fragmentados, em geral desprovidos de contextualização à realidade dos alunos.

Essa ênfase ao ensino de conteúdos pode ser entendida como reflexo das influências do movimento iluminista ao final do século XVIII. Inserido no surgimento da Nova Ciência e a consolidação subseqüente do pensamento moderno, o Iluminismo postulava o domínio do conhecimento científico objetivo, verdadeiro e mensurável como forma de atingir a libertação ${ }^{10}$ (Marcondes, 2002). Dessa forma, a liberdade e a igualdade, máximas do emergente pensamento liberal da época, só seriam garantidas àqueles que pudessem 'iluminar-se' por meio da aquisição do conhecimento científico.

Assim, por atribuir tamanha relevância ao conhecimento científico tomado como a peça-chave para a libertação do homem (Marcondes, op.cit.), o paradigma moderno do século XIX irá moldar a concepção de conhecimento, ensino e aprendizagem dos sistemas educacionais de seu tempo e de tempos subseqüentes tal como evidenciam as concepções de Aida e Beatriz.

Nas palavras de Severino (1986: 40), trata-se da crescente cientificização da educação, o que irá refletir um sistema de ensino de base epistemológica racionalista que implicará a primazia da neutralidade e objetividade na transmissão dos conteúdos. Podemos dizer que esse projeto de educação liberal remete à concepção humanista tradicional de que trata Saviani (1991) na medida em que o autor a caracteriza pela transmissão dos saberes e pela centralidade do professor nesse processo de ensino e aprendizagem.

No que diz respeito à Sofia, professora do colégio Áureo, podemos igualmente afirmar a ênfase ao ensino de conteúdos gramaticais e lexicais da língua inglesa. Nossa interpretação é sustentada diante da análise das provas escritas elaboradas pela própria professora. No Anexo 7, por exemplo, o exercício 4, parcialmente transcrito a seguir

\footnotetext{
${ }^{10} \mathrm{O}$ próprio projeto enciclopedista de Diderot àquela época, com sua ambição de totalidade e sintetização dos saberes, é um indício da relevância atribuída à ciência e à razão.
} 
(Figura 5), enfatiza o uso do verbo To Be e do verbo have got em suas formas afirmativa e negativa:

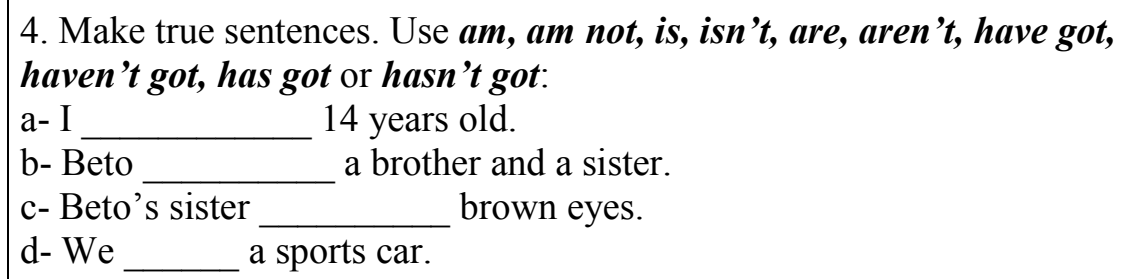

Figura 5: exercício gramatical, com ênfase para o uso de formas verbais, extraído do Anexo 7.

A ênfase ao conteúdo gramatical pode ser igualmente notada no exercício 5, em que os alunos devem completar os espaços com a preposição correta "on" ou " $a t$ " e ainda no exercício 6 (Figura 6) da mesma prova, o qual solicita o preenchimento de lacunas com a forma correta do verbo there to be:

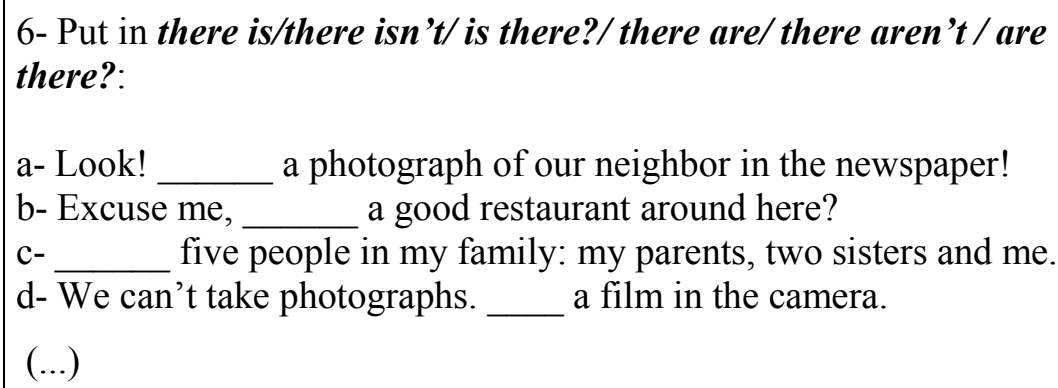

Figura 6: exercício gramatical, com ênfase sobre o verbo there to be, extraído do Anexo 7.

O exercício 3 (Figura 7) do Anexo 8 também prioriza os mesmos aspectos gramaticais, pois busca verificar o domínio do uso do tempo verbal Presente Simples:

3- Complete the sentences with the verbs in parentheses. Use the Present Simple Tense in the correct form:

My name (be) Doug Winston. I (live) in New York with my parents. We (live, not) in a house. Our home is a large apartment in an old building. My mother and my father both (be) a writer (...) (work). My mother

Figura 7: exercício de preenchimento de lacunas com verbos, extraído do Anexo 8. 
Apesar da regularidade nas atividades quanto ao tratamento da língua como código lingüístico, é curioso notar certas descontinuidades nas narrativas de Sofia ao investigarmos o que a professora entende por língua.

Essas descontinuidades na investigação do conceito de língua de Sofia somente podem ser percebidas diante da visão do macro, em que tomamos várias de suas narrativas, num movimento não linear de análise. Ou seja, as próprias discrepâncias nas conceituações de Sofia nos impossibilitam de mostrar um excerto e, em seguida, apresentar nossa análise; mostrar um outro trecho e explicitar uma outra análise e assim por diante. Ao contrário, nossa interpretação é fruto de um constante vaivém das leituras dos excertos escolhidos e doravante apresentados.

Um dos trechos mais interessantes e instigantes para a investigação do que Sofia entende por língua é o que segue. A pergunta foi inicialmente elaborada com enfoque sobre os projetos que a professora desenvolve com os alunos, mas, durante sua narrativa, Sofia decide tratar da questão da aprendizagem de uma língua estrangeira, fornecendo-nos informações significativas, apresentadas em negrito:

((você trabalha bastante com projetos... ainda dá pra trabalhar?))

Sofia: dá...você viu... ( ) o tema aquecimento global... global warming... aí eles/tá certo que tem muita gente/muitos pais que falam assim/como que o meu filho vai procurar na Internet um negócio desses porque ele não vai entender nada do que está lá e tal... aí vem o que o aluno também quer... porque nós não vamos traduzir tudo... nós vamos ter também que ver a mensagem/a... como que eu vou dizer? não é por assimilação... ( ) é neurolingüística pura... como que nós aprendemos a nossa língua? Como que nós aprendemos a falar português? $\mathbf{E}$ a gente fala rápido por que? porque a gente escuta rápido... porque a gente repete:: repete:: então nós escutamos a repetição dos nossos pais... dos nossos parentes:: do cachorro:: do gato:: eu até brinco com eles... então é como eu digo... por que que o surdo-mudo não fala? Porque ele não escuta... não é porque ele tem problemas... tem uns que têm mas a maior parte é por causa do ouvido não por causa da oralidade... porque a fala ela é inata...nós nascemos com essa fala... agora a linguagem não... é adquirida né... não... é adquirida... então é por isso que o Mowgli:: eu também falo pra eles e eles dão risada... porque se a gente (vive) com os lobos:: nós vamos falar a língua dos lobos:: se a gente nasce vive com os macacos que nem o tarzan:: nós vamos falar a língua dos macacos:: por que/porque nós estamos escutando aquilo... e eles gostam quando a gente fala isso ( ) $O$ Mowgli fala inglês só no cinema (risos)... porque ele não fala nada né? ele gru/ ele uiva né... 
O longo trecho em negrito evidencia uma concepção da psicologia da educação sobre a fala, cujo desenvolvimento depende das relações e contextos sociais e culturais. Ao fazer referências aos personagens fictícios Mowgli e Tarzan, Sofia remonta à intrigante questão do desenvolvimento psicológico dos processos de aprendizagem ocorridos com sujeitos sem contato com nenhum grupo social, dentre os quais mencionamos o caso verídico do menino Vitor de Aveyron, encontrado no início do século XIX num bosque francês pelo médico Jean Itard (Monte Mór, 1996).

A reintegração de Vitor ao mundo civilizado realizada por Itard mostra o papel imprescindível das relações e contextos sócio-culturais para a aquisição de habilidades, comportamentos e sensibilidades. No que diz respeito à aquisição da fala especificamente, o fato de Vitor não ter tido o mesmo sucesso que teve com outras habilidades revela uma relevância ainda maior dessas relações sociais e culturais, as quais têm papel fundamental desde os primeiros anos de vida na medida em que previnem o atrofiamento dos músculos do aparelho fonador, tal como o próprio Itard concluiu. Nesse sentido, a experiência de Vitor corrobora as idéias de Vygotsky e Levina (apud Monte Mór, ibidem: 110), para quem a linguagem, diferentemente de outros tipos de comportamento, se desenvolve do coletivo para o individual.

Na difícil tarefa de delinear o conceito de língua de Sofia, julgamos relevante considerar as constantes referências que a professora faz às palavras assimilação, repetição e tradução. Trata-se, em geral, de conceitos tipicamente discutidos no bojo das teorias de aquisição de línguas, área de interesse da professora. Esses conceitos aparecem também no seguinte excerto:

Sofia: da primeira a quarta eu troquei TUDO... eu coloquei o Let's Go ${ }^{11} \ldots$ por que? porque o Let's Go é neurolingüística PURA... porque aprende através da assimilação:: da repetição espaçada:: o aluno não tem que aprender tudo na vida... não precisa ficar falando traduzindo... todos aqueles textos que são do Homo Sapiens que também não é o que eles querem que passa/eu vi que realmente não era isso... a proposta do Homo Sapiens NÃO É ESSA... A proposta do Homo Sapiens É neurolingüística pura... aula dada é estudada... antes de dormir você tem que rever tudo pra você não ir dormir/ entender... tem que passar tudo pro outro lado do cérebro...senão você não entende nada..

\footnotetext{
${ }^{11}$ Livro-texto utilizado para o ensino da língua inglesa para crianças entre 6 e 10 anos.
} 
Sofia entende a repetição como processo imprescindível para o aprendizado da fala. A professora parece seguir preceitos piagetianos ao referir-se à assimilação do indivíduo ao seu meio no desenvolvimento de sua comunicação (porque aprende através da assimilação:: da repetição espaçada) ao mesmo tempo em que avança nas teorias psicológicas de processos de aprendizagem quando, no excerto anterior, destaca a questão das interações sociais, uma contribuição da abordagem sócio-cultural de Vygostsky.

No que diz respeito à tradução, no entanto, Sofia coloca-se contrária ao seu uso por considerá-la desnecessária (o aluno não tem que aprender tudo na vida... não precisa ficar falando traduzindo...), talvez por influência das estratégias do ensino instrumental de línguas proposto pelo sistema Homo Sapiens, conforme veremos mais adiante.

O uso da tradução no ensino de línguas estrangeiras, criticado por Sofia mas recorrente em outros contextos educacionais, como é o caso de Aida e de Beatriz, remete à forte influência do Grammar Translation Method predominante na Europa na segunda metade do século XIX e primeira metade do XX (Richards e Rodgers, 1996). Em sendo o objetivo do método tornar alunos leitores eficientes dos clássicos, suas técnicas consistiam na tradução de obras da literatura clássica, no estudo e memorização de regras gramaticais e de listas de vocabulário e no enfoque à leitura e à escrita.

Considerando tais preceitos, os conceitos de língua e as práticas pedagógicas de Aida, Beatriz e Sofia não deixam de ressoar algumas dessas técnicas, embora as participantes da pesquisa demonstrem em certos momentos outros conceitos que vão além dos princípios do Grammar Translation Method, como é o caso da crítica promovida por Sofia ao uso da tradução e da crítica de Beatriz com relação à memorização de conteúdos.

Em nossa leitura, isso ocorre em função das próprias transformações nas formas de ensino de línguas no decorrer do século XX, após o Reform Movement, cujas implicações práticas foram o desenvolvimento de vários métodos de ensino que começaram a enfatizar outros aspectos da língua outrora negligenciados, como a oralidade, a questão do significado da língua e ainda a importância do contexto e das situações discursivas (Richards e Rodgers, op.cit.) 
Assim, as descontinuidades entre conceituações e práticas parecem ser, de um lado, fruto da grande influência do Grammar Translation Method e, de outro, decorrentes das contribuições de outras abordagens. Beatriz, por exemplo, faz uso da tradução, prioriza os aspectos gramaticais e lexicais, mas vê a memorização com ares de reprovação; Sofia, por sua vez, promove uma crítica ao uso da tradução, embora priorize em suas aulas e provas escritas o tratamento da língua como código lingüístico; contraditoriamente, a professora faz uma certa apologia da repetição (o Let's Go é neurolingüistica PURA... porque aprende através da assimilação:: da repetição espaçada::) ao demonstrar simpatia pela Neurolingüística.

A respeito de sua referência a Neurolingüística, a professora trata dessa questão mais detalhadamente em outro momento da entrevista:

Sofia: essa lei de aula dada aula estudada eu acho ótimo... ((Sofia referese ao sistema Homo Sapiens)) bate com tudo que eu acho certo porque eu estudei muito neurolingüística não só porque/pra dar aula... eu gosto dessas coisas... então além de eu fazer curso eu fui ler eu sempre fui em busca dessas coisas... (...) eu acho que tem uma terapia... que é a TNL que é a terapia neurolingüística... que eu acho mais rápido:: mais evidente:: eu não sei se eu sou adepta a isso mas ela chama TNL... e ela/por que o que que acontece com a neurolingüística? é a parte psicológica do cérebro e a parte mecânica/é um computador... se a gente consegue pôr um disquete:: ligar:: colocar:: montar tudo:: organizar:: ou perder:: ou deletar:: não é... por que que você não pode fazer isso com a tua cabeça? porque é isso que se juntaram um psicólogo/eu não vou lembrar o nome agora... era um psicólogo e um:: digitador:: o:: o técnico em computação... eles se juntaram e descobriram a neurolingüística... aí os mais espertos como também o:: nosso amigo lá como é o nome dele aquele do computador? Bill Gates:: o que que ele fez? ele vê... pegou aquilo que ninguém entendeu e é isso que a gente tem que usar porque a inteligência é uma coisa/a inteligência é inata... tá lá tal... (você tem você não tem)... mas a competência é o único (lugar) da inteligência... se você não usa a competência atrofia tudo não é? que nem um músculo... ( )... eu queria que eles trouxessem/quando a Juliana a Daniela me falou/ ai a gente pode trazer/pode falar do papai Noel? ((no projeto sobre Global Warming)) eu falei CLARO que pode ele veio de lá... ((refere-se ao Pólo Norte)) mas olha como ela já FOI mais além... É ISSO que eu quero... o construtivismo É ISSO...

A concepção de Neurolingüística de Sofia, aparentemente caracterizada como um estudo não legitimado pela própria professora (eu estudei muito neurolingüística não só 
porque/pra dar aula... eu gosto dessas coisas... ${ }^{12}$ ), não parece condizente com os pressupostos teóricos da NLP (Neurolinguist Programming), cujo conceito, segundo Richards e Rodgers (2001) está muito mais voltado a uma filosofia humanista da psicologia popular, ao invés de uma proposta fundamentada numa determinada teoria de linguagem, caracterizando-se como "coleção de técnicas e estratégias que visam à comunicação efetiva, ao crescimento pessoal e ao aprendizado seguindo preceitos quanto ao funcionamento da mente e à forma de agir e interagir das pessoas" (Revell and Norman, 1997 apud Richards e Rodgers, op.cit: 125)

Ao final desse mesmo excerto, nota-se que a professora faz referência a um dos projetos realizados com a $5^{\mathrm{a}}$ série, sobre os quais convém mencionar algumas informações. Tivemos a oportunidade de acompanhar dois projetos com a $5^{\text {a }}$ série: no segundo bimestre, a professora propôs como tema central "Animais em extinção", sendo que no quarto bimestre o projeto abarcou o tema "Global Warming". Em termos procedimentais para ambos os projetos, os alunos tinham que, num primeiro estágio, procurar figuras e textos na Internet sobre o referido tema. Feitas as pesquisas individuais em casa, os alunos traziam o material para a escola e passavam a trabalhar em grupos sentados ao chão num 'exercício de colagem' de imagens e textos impressos em inglês, em que simplesmente tinham que pensar as disposições destes sobre as cartolinas cedidas pela professora.

A atividade com projetos durava cerca de 5 aulas e ao término do trabalho os pôsteres eram fixados em murais dos corredores da escola. No excerto transcrito acima, Sofia faz referência ao projeto "Global Warming", do $4^{\circ}$ bimestre. O trabalho com projetos é a prática mais mencionada por Sofia ao longo da entrevista e das conversas informais ao final das aulas e fundamenta sua preferência pela abordagem construtivista, evidenciada em vários trechos, dentre os quais o que se segue:

Sofia: enquanto língua... vamos dizer 0 inglês/enquanto língua estrangeira moderna né... o inglês instrumental eu acho que ele bate muito bem com o Construtivismo... enfim... agora não dá pra você (fazer tudo) lindo perfeito né... não dá...pra você né... a formação:: precisa de um embasamento... fazer uma construção... precisa de alicerce... ((você diz da escola... de todos?))

${ }^{12}$ Grifos nossos. 
Sofia: é... de todos... mas não só nessa escola... de todos... O São Tomé começou com o Construtivismo mas não é nada... não é nem uma coisa nem outra lá.. é o que eu falo não que a gente não possa aproveitar/e outra coisa eu fiquei lá três anos e aproveitei muita coisa... fiz projetos e tal:: eu cheguei a te dar a apostila da Vivere ${ }^{13}$ ? Eu não sei se você tirou xerox:: nem lembro mais... eu NÃO POSSO perder aquela apostila porque aquilo é uma construção... a gente ajudou (a montar)...

Entendemos que as constantes referências de Sofia ao Construtivismo possam representar seu interesse por questões educacionais mais amplas, uma vez que a professora não se restringe à questão dos métodos de ensino de línguas. Em outras palavras, as menções de Sofia ao Construtivismo parecem evidenciar seu entendimento quanto à relevância de se tratar da educação partindo de seu cerne, buscando uma concepção de educação que fundamentará um determinado modelo pedagógico, no caso, um método de ensino.

É curioso notar nesse mesmo excerto que a própria Sofia parece consciente da dificuldade ou até mesmo a impossibilidade de adotar $\underline{u m a}^{14}$ determinada proposta pedagógica, tal como o Construtivismo, e segui-la à risca, em total conformidade com seus pressupostos teórico-metodológicos, e ainda com o projeto político-pedagógico da instituição. Ao se referir a um dos colégios onde trabalhou (O São Tomé começou com o Construtivismo mas não é nada... não é nem uma coisa nem outra lá.. é o que eu falo não que a gente não possa aproveitar) parece-nos que Sofia, apesar de eleger o Construtivismo como a abordagem de ensino de sua preferência, entende a necessidade de adaptação na sala de aula como prática inerente diante das contradições e descontinuidades dos próprios contextos onde a professora já lecionou inglês.

Isso parece remontar ao que Prabhu (1987: 103) chama de "senso de plausibilidade". O autor acredita que a prática pedagógica de um professor nunca é determinada exclusivamente em função do método de ensino pretendido por ela, ou até mesmo por sua instituição, dada a existência de um complexo de "forças externas" em jogo, nas mais variadas formas e graus.

\footnotetext{
${ }^{13}$ São Tomé e Vivere constituem nomes fictícios de colégios onde Sofia já trabalhou como professora de inglês.

${ }^{14}$ Grifo nosso.
} 
Dentre essas forças explicitadas pelo autor, destacamos o "senso de lealdade ao passado" por considerarmos plausível para nossa análise do que Sofia entende por língua. Essa lealdade ao passado, assumida aqui como uma vontade de manter determinadas conceituações e práticas outrora predominantes na carreira do professor, pode ser depreendida, por exemplo, quando Sofia faz referências ao Construtivismo em tom de nostalgia (eu NÃO POSSO perder aquela apostila porque aquilo é uma construção... a gente ajudou a montar...).

Acreditamos que os efeitos do senso de lealdade ao passado referido por Prabhu (op.cit.) devem ser relativizados na medida em que podem acarretar tanto uma prática pedagógica mais interessante e significativa quanto uma prática pedagógica retrógrada, arraigada em princípios convencionais.

Tomando, por um lado, o senso de lealdade ao passado como um 'retrocesso', buscamos a referência que Favaretto (1995: 06) faz quanto à nostalgia ao passado no bojo do discurso pós-moderno, cuja negação da totalidade abalou os alicerces sólidos trazidos pela modernidade, provocando uma sensação de vazio em alguns discursos do campo educacional e a conseqüente busca de soluções em práticas passadas:

(...) compreende-se a ênfase atual na restauração da unidade, julgada perdida, para dar conta de um suposto vazio de idéias; compreende-se a insistência no resgate do passado, alegado para suprir a falta de referências e fundamentos.

Por outro lado, entendemos que o senso de lealdade ao passado de que trata Prabhu (op.cit.) possa mostrar-se interessante se o professor, ao longo de sua formação, teve contato com teorias de ensino mais adequadas se comparadas com as que lhe são impostas no exercício atual de sua profissão.

Dessa forma, enquanto o discurso moderno totalizante rompe com o tradicional, caracterizando o passado como algo ruim, o discurso da pós-modernidade atribui um novo papel à tradição, rompendo com alguns de seus aspectos e dialogando com outros na busca da compreensão de seu tempo. Conforme resume Cordeiro (2002: 38): 
Enquanto o modernismo parodia o passado para com ele romper e construir um futuro novo, revolucionário, o pós-moderno transgride a tradição legada pelo passado de outra maneira, estabelecendo diálogo entre o passado e o presente, sem apontar, de maneira prospectiva, para o futuro.

No caso de Sofia, particularmente, entendemos que seu senso de lealdade ao passado traz, sim, uma prática pedagógica mais interessante, já que a professora, em alguns momentos de sua aula, subverte o ensino linear e cumulativo postulado pelo sistema Homo Sapiens de ensino e propõe - ou ao menos tenta propor - um ensino colaborativo e contextualizado por meio do trabalho com projetos. Sua experiência passada bem sucedida com a pedagogia construtivista faz com que Sofia utilize de seu poder de agência para suspender por alguns instantes o ensino neo-tecnicista do sistema apostilado Homo Sapiens.

Assim, o tom nostálgico com que Sofia trata do Construtivismo não nos parece vir imbuído de significado negativo; pelo contrário, a professora parece ensaiar uma crítica à homogeneidade do ensino pretendida pelo sistema Homo Sapiens, uma prática tipicamente dos anos 60 e reverberante na atualidade, em detrimento dos bons frutos que colheu em sua prática docente construtivista alguns anos atrás. Trata-se de um 'velho' modelo para Sofia, mais interessante que o 'novo' modelo proposto pelo sistema de parcerias entre a escola (Colégio Áureo) e empresa-escola (sistema Homo Sapiens), aliás, um novo que nos parece mais velho do que nunca, naturalmente em seu sentido retrógrado.

Isso porque a abordagem construtivista a que se refere Sofia pode ser lida no bojo das propostas progressistas de ensino referidas por Saviani (1991) como uma concepção humanista-moderna de educação, a qual assume a negação do caráter essencial da realidade postulado pela concepção humanista-tradicional. Ao tratar da natureza inacabada do homem, essas propostas pedagógicas passaram a priorizar o lugar do aluno em detrimento do papel centralizador do professor, o que constituiu, em seu tempo, uma grande contribuição no desenvolvimento das teorias de ensino e aprendizagem. 
Isso implica, nas palavras de Tosi (2003: 102), a priorização da relação sujeito-objeto no processo de aquisição de conhecimento e o compromisso em implementar um currículo que possa desenvolver a criatividade e independência do aluno em "um clima de liberdade, participação e compreensão entre professor e alunos e estes com eles mesmos".

As tentativas de uma pedagogia construtivista por parte de Sofia evidenciam alguns momentos de priorização do lugar do aluno no processo de ensino e aprendizagem. Nos trabalhos com projetos, por exemplo, alguns alunos traziam sugestões para a professora quanto às figuras que poderiam colar ou os desenhos que poderiam elaborar, sugestões acatadas e elogiadas pela professora, conforme o seguinte trecho transcrito anteriormente, mas reproduzido aqui para essa análise específica:

Sofia: (...) eu queria que eles trouxessem/quando a Juliana a Daniela me falou/ ai a gente pode trazer/pode falar do papai Noel? ((no projeto sobre Global Warming)) eu falei CLARO que pode ele veio de lá... ((refere-se ao Pólo Norte)) mas olha como ela já FOI mais além... É ISSO que eu quero... o construtivismo É ISSO...

Em outro momento da entrevista, a mesma relevância com que Sofia trata do papel do aluno em sua própria construção do conhecimento pôde ser notada, em oposição à mera transmissão de informações por parte do professor:

Sofia: (...) eles têm que começar a APRENDER que eles têm que ter RESPONSABILIDADE... quinta série não dá mais pra ficar brincando... eles têm isso do primário que a professora faz tudo... tudo bem eu acho isso ótimo/tudo bem... mas eu não me cobro (pra tanto) então no último bimestre ... então esse tipo de trabalho também é pra mexer um pouco com lógica:: com o discernimento deles... pra ver se eles também começam a ter um pouco de idéias sem a mão da gente... então a gente joga (pra explicar) mas é bom que eles tragam alguma coisa...com certeza eles são muito acomodados...

A questão da criatividade e independência do aluno e o clima de participação e compreensão postulados pelo Construtivismo (Tosi, op.cit.) podem ser vistos no seguinte excerto, em que Sofia tece elogios às idéias de alguns alunos em uma das aulas de projeto. Trata-se de mais uma evidência da tentativa da professora em desenvolver na prática uma concepção progressista de educação: 
Sofia: eu pedi o trabalho em seis... em grupo... então eles tiraram dois de média:: tinha que trazer fotografia:: eu expliquei sobre o que era...muitos alunos tiveram idéias brilhantes... uma aluna falou...quer dizer que o papai noel daqui a pouco não vai mais estar no gelo? Já pensou o papai noel numa prancha de surf? ((Sofia refere-se ao trabalho sobre aquecimento global)) você sabe que outro dia eu fui ao shopping e quase que eu comprei... era um papai noel em cima de uma prancha de surf... só não comprei porque era muito caro... eu compraria se fosse mais barato... a Ana Carolina:: a Camila:: desde a primeira série é fantástico trabalhar com elas

Em termos gerais, a teoria construtivista pode ser lida como um desdobramento da nova crise de paradigmas no século XIX, em que o sujeito pensante do modelo cartesiano, fechado sobre si mesmo e obstinado em dominar os saberes, dá lugar ao conceito de sujeito situado historicamente, portanto, resultado de um processo de formação social (Marcondes, op.cit.).

Já com relação às representações de Sofia diante da proposta pedagógica do sistema Homo Sapiens de ensino, é interessante notar que a professora entende a concepção de língua do Homo Sapiens em concordância com preceitos da teoria Neurolingüística quando diz, por exemplo:

Sofia: (...) a proposta do Homo Sapiens É neurolingüística pura... aula dada é estudada... antes de dormir você tem que rever tudo pra você não ir dormir/ entender... tem que passar tudo pro outro lado do cérebro...senão você não entende nada...

Entretanto, discordamos dessa interpretação justamente pelo fato do sistema Homo Sapiens não parecer abarcar as características da NLP descritas em Richards e Rodgers (op.cit.). Além disso, ao buscarmos esclarecer o princípio da "aula dada, aula estudada" do sistema Homo Sapiens, não encontramos qualquer referência a Neurolingüística:

Aula dada, aula estudada. Tudo gira em torno da aula. Em casa, os alunos estudam diariamente as aulas dadas, ao fazer as tarefas. Com o material Homo Sapiens, o hábito de estudo é incorporado pelo aluno de forma natural.

(Sistema Homo Sapiens de Ensino) ${ }^{15}$

\footnotetext{
${ }^{15}$ Conceito extraído do website do Sistema Homo Sapiens de ensino. Acesso em 25/01/2007.
} 
Em nosso entendimento, além de seu princípio "aula dada, aula estudada" remeter ao conhecimento gradativo, linear e cumulativo, o sistema Homo Sapiens de ensino parece estar de acordo com os princípios do ensino instrumental, uma proposta de ensino que abarca a concepção analítica da educação de que trata Saviani (1991), definida como prática pedagógica cuja preocupação consiste em preparar o indivíduo para a sociedade. Conforme expõe Saviani (ibidem: 20), esse modelo tecnicista de ensino foi predominante em âmbito nacional a partir da década de 70 por influência do neopositivismo e das próprias conquistas tecnológicas, donde se pode inferir a ênfase ao ensino de conteúdos úteis para o funcionamento do indivíduo em sua comunidade.

A difusão do que hoje se conhece por ensino instrumental de línguas está relacionada com a crescente demanda pela leitura de textos em língua estrangeira em tempo hábil no final da década de 70. O principal objetivo desse modelo de ensino, outrora conhecido por ESP (English for Specific Purposes) é a capacitação do aluno a "ler e compreender o essencial para o desempenho de determinada atividade” (Sedycias, 2002). Assim, pautado no ensino das chamadas survival skills (Luke \& de Castell, 1989) e compromissado com a idéia de capacitação do aluno, o ensino instrumental de línguas não deixa de suscitar a problemática questão da relação entre educação e mercado, donde a preocupação em preparar o aluno para o desenvolvimento eficaz e imediato de tarefas não abrange a contextualização desse ensino com as práticas sociais ${ }^{16}$ dos sujeitos envolvidos nesse processo.

Essa caracterização do ensino instrumental vem corroborar nossa leitura de que o sistema Homo Sapiens, apesar de propor a formação integral do aluno, evidencia sua proposta pedagógica essencialmente vinculada à preparação para o mercado de trabalho desde os níveis elementares, conforme o trecho abaixo, extraído de seu website:

Estudante criativo e versátil: o mercado de trabalho exige, cada vez mais, profissionais que aprenderam a ser criativos e versáteis desde os primeiros anos de vida.

(Sistema Homo Sapiens de Ensino)

\footnotetext{
${ }^{16} \mathrm{O}$ sentido de práticas sociais assumido neste trabalho refere-se às formas de produção de significados e conhecimentos e sua relação com as experiências dos sujeitos em seus contextos sócio-culturais. Não se constitui, portanto, sinônimo de práticas com vistas a atingir objetivos de mercado, mas, sim, de práticas em que se privilegia o olhar crítico do sujeito sobre seu entorno.
} 
Nota-se, nessa descrição, a menção de conceitos como 'criatividade' e 'versatilidade', os quais também têm sido assinalados por teóricos dos novos estudos de letramento. A esse respeito, entendemos que a proposta de formar um "estudante criativo e versátil" do sistema Homo Sapiens justifica-se diante das exigências do mercado neoliberal, diferentemente das idéias de Cope e Kalantzis (op.cit.), por exemplo, os quais destacam a questão da criação (design, no original) como um dos elementos-chave na pedagogia de multiletramentos e na formação de sujeitos capazes de se posicionarem, negociarem e lidarem de forma crítica em situações diversificadas. Tais situações naturalmente abarcam os futuros ambientes de trabalho dos alunos, mas estes não constituem o cerne das teorias de letramentos, tal como parece ocorrer na proposta pedagógica do sistema Homo Sapiens.

Ao retomarmos os trechos anteriormente transcritos, é possível afirmar que Sofia ressalta o caráter instrumental do sistema apostilado e, contraditoriamente, articula-o com a abordagem construtivista (o inglês instrumental eu acho que ele bate muito bem com o Construtivismo... enfim..), após já tê-lo representado como modelo de ensino coerente com os pressupostos da Neurolingüística (A proposta do Homo Sapiens É neurolingüística pura... aula dada é estudada... essa lei de aula dada aula estudada eu acho ótimo... bate com tudo que eu acho certo porque eu estudei muito neurolingüística). Assim, o entendimento de Sofia com relação à proposta pedagógica do Homo Sapiens mostra-se descontínuo e contraditório.

\section{Asserções Iniciais}

Diante dos trechos selecionados para análise, as narrativas de Sofia acabam por nos revelar uma descontinuidade na construção de sua representação acerca do ensino e aprendizagem de língua estrangeira na medida em que a professora faz apologia do Construtivismo ao mesmo tempo em que sinaliza certa simpatia pelo ensino instrumental proposto nas apostilas, havendo espaço, ainda, para incluir o conhecimento que ela tem produzido ao longo de sua experiência docente nos cursos de formação continuada, como é o caso do curso sobre Neurolingüística. De forma semelhante, embora em menor grau, Beatriz também demonstra certas descontinuidades em suas próprias conceituações e na articulação destas com sua prática pedagógica. 
Lançamos, portanto, um questionamento: estamos diante de um interessante ecletismo pedagógico ou de inconsistência teórico-metodológica?

Esta pesquisa não pretende assumir uma postura prescritiva com relação às concepções de língua das professoras e a articulação destas com suas práticas, mas considera relevante compartilhar as dificuldades com que abordamos essa questão. Isso se explica na medida em que, embora situados no bojo das teorias pós-estruturalistas, cujas idéias de descentramento e multiplicidade de significações negam o ideal de coerência e de unicidade posto pelo pensamento moderno, não podemos ingenuamente cerrar os olhos para toda a influência liberal-positivista presente nas sociedades atuais. Nesse sentido, as representações dos sujeitos de pesquisa, sobretudo de Sofia, dão margem a múltiplas interpretações, podendo ser lidas como fruto das próprias contradições inerentes aos processos de significação, ou como uma inconsistência teórica advinda da falta de conhecimentos formais acerca das abordagens de ensino de línguas ou ainda como uma outra terceira interpretação. Uma vez compartilhadas, optamos por deixar o leitor construir seus próprios sentidos acerca de tais narrativas, convidando-o, porém, ao difícil exercício de enxergar as contradições com novos olhares, em que a noção de 'contra'-dições e de 'des'-continuidades não assumissem necessariamente significados negativos.

Recorremos novamente a Prabhu (op.cit.) como forma de esclarecer nosso ponto de vista acerca das descontinuidades encontradas em nossas investigações. A fala do autor (op.cit: 108) diz respeito a uma de suas definições de "ecletismo" no ensino de línguas:

Eclecticism is a matter of operating with a combination of perceptions or procedures which, though all different and some perhaps arguably inconsistent with others, have nevertheless found a satisfying balance in the mind of an individual.

A própria prática pedagógica de Sofia, a qual se mostrou estruturalista em meio a tentativas de atividades tipicamente construtivistas, corrobora essas 'construções conceituais móveis' e a constante procura por um equilíbrio satisfatório entre sua compreensão de língua e sua prática escolar. Ao buscar respaldo em teorias variadas advindas da psicologia da educação (como o Construtivismo e as teorias sobre aquisição da linguagem) e mesmo de aprendizados diferenciados e nem sempre legitimados pela 
academia na medida em que objetivam tornar o ensino mais atraente ou eficaz (como é o caso da Neurolingüística), talvez Sofia esteja tentando explicar as possíveis dificuldades que encontra em sua prática pedagógica diária.

Esse quadro possibilita-nos a leitura de que, por não fazerem uma reflexão aprofundada sobre os motivos da emergência dessas adversidades da prática escolar, alguns professores podem lançar mão de um rol de explicações variadas, algumas coerentes entre si, outras descontínuas e ambíguas.

Há que se considerar, também, como possível razão para esse uso variado e descontínuo de explicações, o desconhecimento sobre determinadas teorias que respondessem melhor a essas inadequações do ensino. Essa interpretação passa a ser plausível no momento em que Sofia relata a insatisfação dos pais dos alunos quanto à pesquisa na Internet sobre os temas dos projetos:

Sofia: o tema aquecimento global... global warming... aí eles/tá certo que tem muita gente/muitos pais que falam assim/como que o meu filho vai procurar na Internet um negócio desses porque ele não vai entender nada do que está lá e tal... aí vem o que o aluno também quer...

Durante a coleta de dados, Sofia demonstrou uma concepção de Internet como ferramenta ou recurso técnico de reprodução lingüística, diferentemente da concepção de Internet postulada pelas teorias de letramentos como uma nova linguagem ou modo de significação muito mais amplo (Lankshear e Knobel, 2003). Isso porque em momento algum a professora demonstrou utilizar a Internet como um meio multimodal de representação, limitando-se a solicitar aos alunos a busca de textos que tratassem do tema do projeto previamente estabelecido, um exercício que poderia ter sido realizado com qualquer enciclopédia, tal como costumávamos fazer nos trabalhos escolares individuais ou em grupo, salvas as devidas diferenças quanto às 'facilidades' oferecidas pelas impressoras aos alunos do século XXI.

Concomitante, porém, às descontinuidades e contradições passíveis de ocorrência em qualquer prática social, é possível notar algumas semelhanças nas práticas de ensino dos três contextos observados. Partindo das observações das aulas e da análise dos 
documentos $^{17}$, podemos afirmar que as aulas de inglês nas três realidades tratam essencialmente das estruturas gramaticais da língua, como uso correto de verbos auxiliares, estruturação de perguntas e respostas, uso de pronomes. Há também exploração de aspectos lexicais quando do trabalho com vocabulário específico, como animais, membros da família, profissões ${ }^{18}$.

Essa análise inclui a prática de Sofia, cujas aulas não demonstraram, a nosso ver, a utilização de métodos ou técnicas nem construtivistas nem baseadas na NLP, apesar da apologia da professora a ambos. Isso porque o trabalho de cooperação proposto pelo Construtivismo nas atividades em grupo (Mizukami, 1986) não ocorreu na medida em que, nos trabalhos com projetos, por exemplo, muitos alunos nem sabiam o que tinham que fazer, aproveitando o tempo para conversarem sobre assuntos diversos. A função de instigador do professor, uma outra característica do Construtivismo, pôde ser percebida em alguns momentos, sim, mas muito pouco explorada e por vezes não perceptível para muitos alunos.

Esse quadro em que discrepâncias e semelhanças, descontinuidades e regularidades surgem amalgamadas parece ilustrar as tentativas ou mecanismos de mudança de rumos diante de uma base epistemológica dominante. No caso do ensino de línguas, parece evidente que o conceito de língua como código lingüístico pautado numa epistemologia convencional de conhecimento, encontra-se arraigado em tais práticas pedagógicas, sendo talvez responsável pelas certas regularidades que encontramos ao longo da pesquisa. Simultânea e curiosamente, porém, encontram-se as descontinuidades nesses mesmos contextos, assumidas neste trabalho como inerentes das próprias relações humanas e possivelmente otimizadas por determinados sujeitos, aqueles que se mostram ávidos por novos ares, que arriscam novas formas, tendo com isso a necessidade de recriar os sentidos de suas próprias práticas sociais. Assim nos parece Sofia, em maior proporção; assim se apresenta Beatriz, em menor grau; e assim poderá apresentar-se Aida, em outras vivências suas que não necessariamente voltadas à educação.

Embora extensas, as palavras de Vasconcellos (2003: 14) parecem ressoar algumas das idéias que acabamos de apresentar:

\footnotetext{
${ }^{17}$ No caso, as atividades e as provas escritas desenvolvidas pelas professoras.

${ }^{18}$ De acordo com as anotações de campo durante a observação das aulas.
} 
(...) sempre há uma autonomia relativa de uma instância em relação à outra (embora em inúmeras situações, em proporções muito diferentes), o que permite transformações entorno de uma continuidade; do contrário, a história simplesmente não existiria, já que o que teríamos seria a eterna reprodução do mesmo (no caso da prevalência absoluta do meio) ou episódios totalmente desbaratados (quando da prevalência absoluta do indivíduo). ${ }^{19}$

\title{
1.2 Retratos do modelo neoliberal de educação e o poder de agência
}

Em termos gerais, podemos afirmar que as representações acerca do ensino e aprendizagem de língua inglesa tanto de Aida quanto de Sofia são construídas em meio a considerações bastante pontuais sobre o sistema Homo Sapiens de ensino em decorrência do fato de ambos os colégios constituírem escolas-parceiras. Aida demonstra simpatia pelo sistema Homo Sapiens, embora apresente algumas ressalvas, conforme podemos inferir de sua fala:

\begin{abstract}
Aida: (...) eu acho que é um conteúdo legal... eu gosto de trabalhar com a apostila Sapiens... mas o problema é que eu acho que poderia ter MAIS aulas... pra gente poder sabe? Enunciar mais os conteúdos... porque às vezes eu to explicando e eu percebo que aquilo tá ficando MUITO no ar... é MUITO fora da realidade... é uma coisa assim, como eu posso dizer, muito fora do concreto, eles não sabem lidar com aquilo como a língua portuguesa por exemplo que eles já estão acostumados... então inglês acaba sendo muito mais difícil... mas você tem que meio que tentar tampar o sol com a peneira ali e falar "bom, mais pra frente eu volto nesse conteúdo de novo e muitas vezes você acaba ficando perdida assim né? pra mim...se eu vou deixando muito de lado o cronograma depois lá na frente eu me enrolo... então a gente tem que, eu tento priorizar o aluno mas ao mesmo tempo colocar as minhas prioridades porque senão se ficar só naquele aluno ou um ou outro que segura... que trava a aula aí não se faz mais nada.
\end{abstract}

As ressalvas de Aida dizem respeito à falta de tempo para cumprir todo o conteúdo da apostila atrelado à falta de contextualização desses conteúdos com a realidade dos alunos. Sua reclamação quanto à escassez do número de aulas para cumprir o programa leva-nos a concluir que a professora não utiliza de sua possibilidade de agência diante do que lhe é exigido pelo colégio, assumindo fielmente a responsabilidade de cumprir

\footnotetext{
${ }^{19}$ Grifos do próprio autor.
} 
sua função: ensinar todo o conteúdo das apostilas no decorrer do ano letivo, mesmo que alguns de seus alunos não tenham aprendido significativamente (vide trechos em negrito no excerto anterior). Em nosso entendimento, a programação de aulas do sistema Homo Sapiens não prevê agência como forma de garantir a unidade entre as escolas parceiras.

A professora também parece não utilizar-se de seu poder de agência uma vez que, embora pareça consciente do ensino descontextualizado e fragmentado das apostilas do Homo Sapiens (porque às vezes eu to explicando e eu percebo que aquilo tá ficando MUITO no ar... é MUITO fora da realidade... é uma coisa assim, como eu posso dizer, muito fora do concreto), não toma atitudes diante do quadro. Isso pôde ser percebido em nossas observações de aula, em que Aida não pareceu em momento algum promover o ensino do inglês de forma contextualizada; ao contrário, boa parte de suas explicações gramaticais pode ser considerada mecanicista e abstrata.

Uma outra evidência de que Aida não faz uso de seu poder de agência constitui o seguinte trecho, em que a professora revela como trabalha a questão da heterogeneidade em uma mesma turma:

Aida: às vezes eu pego/se eu percebo que a defasagem tá sendo muito grande então aí eu vou fazendo exercícios extras pra que ele faça em casa... NEM SEMPRE por isso que eu nem prometo porque às vezes dependendo da demanda de trabalho que eu tenho em casa não dá pra ta seguindo exatamente da maneira que eu gostaria né mas eu procuro fazer o que dá, né? Ás vezes eu pego até os exercícios das próprias provas, coloco de uma outra maneira, entrego e falo "olha você vai fazer, vai me entregar" aí eu dou uma corrigidinha e mando de volta pra eles pra fazer/dar um suporte né? mas algumas vezes não dá pra fazer...

A professora lamenta não conseguir trabalhar com a heterogeneidade de uma maneira diferente, supostamente devido à dificuldade em cumprir todo o conteúdo da apostila. No que diz respeito à heterogeneidade tomada em termos comparativos (de turmas de um mesmo nível escolar), Aida acaba por revelar um certo grau de poder de agência ao conseguir adequar a avaliação dos conteúdos ensinados em turmas diferentes:

Aida: Cê vê a diferença mesmo você vê... o pessoal da quinta "A"... a quinta "B" tem OUTRO tipo de comportamento diante do, né do conteúdo, então eles vão mais rápido tem uma agilidade diferente da outra turma.

((e aí a prova é diferente?)) 
Aida: Não. Aí eu adequo fazendo uma prova no meio termo. Coloco uns exercícios um pouco mais puxados, assim é meio que dividido em três etapas né: o basiquinho, o mais fácil, aí o intermediário e um pouco mais difícil... porque mesmo na quinta " $A$ " eu tenho alunos que têm outro tipo de comportamento assim de evolução eles são mais rápidos do que outros... então aí eu tento ficar no meio termo, dou uma puxadinha e:: eu dou uma facilitadinha...

É interessante notar que os alunos têm conhecimento dessa 'diferença', uma vez que a própria professora deixa isso bastante claro a eles. Trata-se de um argumento forte na tentativa de conseguir a disciplina dos alunos e o tão desejado cumprimento da apostila. Isso pôde ser identificado em uma das aulas observadas, quando a professora diz aos alunos, em tom de ironia:

Aida: Hoje eu vou fazer todos os exercícios do livro. A outra quinta série já fez, mas aqui como tudo é difícil, né? Então hoje nós vamos trabalhar MUITO.

Considerando a forma como Aida se posiciona diante dos alunos, entendemos que seu poder de agência está a serviço das exigências burocráticas do sistema Homo Sapiens de ensino, e que as diferenças de que trata a professora são consideradas por ela um empecilho ao cumprimento eficaz do conteúdo da apostila. Assim, o que constitui prioridade para a pedagogia de multiletramentos, para Aida caracteriza-se como um obstáculo. Essa leitura é corroborada por um outro excerto, no qual observamos o entendimento de Aida acerca das diferenças como sinônimo de entrave:

Aida: eu tento priorizar o aluno mas ao mesmo tempo colocar as minhas prioridades porque senão se ficar só naquele aluno ou um ou outro que segura, que trava a aula aí se não faz mais nada.

Ao identificarmos a preferência de Sofia pelo Construtivismo no âmbito de seu ambiente de trabalho, entendemos que a professora, diferentemente de Aida, utiliza de seu poder de agência na medida em que deixa transparecer uma mobilidade ao variar de acordo com seus diferentes interlocutores, no caso, os alunos, a coordenadora pedagógica e o sistema Homo Sapiens. Isso porque o sistema, adotado pelo colégio Áureo, não condiz com os princípios construtivistas almejados pela professora, conforme tratamos anteriormente. 
Em segundo lugar, há que se considerar as divergências entre Sofia e a coordenadora pedagógica. Em uma das conversas informais, a coordenadora pedagógica do colégio demonstrou sua reprovação diante da alta freqüência de projetos que Sofia desenvolvia com seus alunos. A coordenadora, inclusive, comentou que a professora sabe a língua, mas não sabe ensiná-la. Como tentativa de contra-argumentar, Sofia busca respaldo na relação com seus alunos, sobretudo as crianças das séries iniciais do Ensino Fundamental e demonstra profunda decepção com os comentários da coordenadora:

Sofia: eu fico muuuito... é assim... quando dizem que eu não sirvo pra ser professora... que eu não consigo... eu digo ( ) então eu acho assim é uma afronta pra mim... porque eu me dedico... o que eu fico demorando pra fazer todas essas provas...(...) se você for comigo agora lá na terceira série... quarta série do primário... eles vão levantar todos da carteira e vão vir me beijar:: e vão falar teacher:: teacher:: teacher:: e vão falar em inglês isso e aquilo... pode ser que muitos/eu brigo/ às vezes eu brigo... eu acho que dá pra contornar...outras vezes/ às vezes eu falo ( ) mas eu brinco muito também... eu viro criança junto com eles...eu brigo:: depois eu vou conversar:: eu chamo:: mas eu fico sentida com algumas coisas...

A professora, por sua vez, também deixa transparecer divergências pedagógicas com a coordenadora na medida em que menciona várias vezes, em tom nostálgico novamente, uma grande empatia por Anita, atual coordenadora do Ensino Médio e ex-coordenadora do Ensino Fundamental, e ainda por Sílvia, uma das proprietárias da escola:

Sofia: gosto DEMAIS de trabalhar com a Anita... a Anita tem uma visão... ela veio comigo desde a primeira série/que quando eu entrei ela era do Fundamental I... mas depois ela passou pro Fundamental II e agora ela tá no Médio ( ) então agora pedagogicamente falando eu acho que a Anita:: a Sílvia:: elas têm assim uma/a Sílvia é a dona da escola que é a diretora pedagógica da escola... então ela tem uma visão/ela deixou trocar os livros:: ela viu tudo comigo:: ela gosta dessas coisas... desses projetos...( ) a idéia era ter um tema/e essa coisa de cobrar também/porque quando você tá pondo num projeto/que a gente chama de projeto... porque isso aqui não é bem um projeto mas... eu já dei o encaminhamento:: passei os objetivos:: desde o começo do ano eles têm tudo isso no caderno... quais são os objetivos do projeto:: quais são os encaminhamentos/o andamento do projeto:: primeira etapa:: segunda etapa:: você não chegou a pegar tudo isso? é Construtivismo puro.

Convém compartilhar um comentário de Sofia com relação à Sílvia, pois é revelador tanto de sua empatia com a ex-diretora quanto de sua preferência pela abordagem construtivista. A fala diz respeito à Sílvia, que à época da coleta de dados estava em 
cursos de especialização na Itália, país sobre o qual Sofia igualmente demonstra simpatia possivelmente em referência às contribuições de Maria Montessori no início do século XX e ressoantes no Escolanovismo brasileiro:

Sofia: porque até o ano passado aqui estava tudo em minhas mãos... a coordenadora pedagógica era muito boa nisso... ela tem uma visão bárbara... ela tinha sabe aquela pedagogia?... mas aí mudou a diretora... porque agora ela ((Sílvia)) está fazendo aprimoramento na Itália... porque a Itália/a pedagogia é muito rica... é muito moderno tudo lá... é muito lindo lá... Estados Unidos:: Inglaterra:: a Itália é muito melhor pedagogicamente falando... como que a gente pode falar? O construtivismo:: tudo vem da Itália.

Além dos trechos da entrevista acima transcritos, as divergências entre Sofia e a atual coordenadora vieram à tona de forma bastante transparente no seguinte evento que pudemos presenciar. Num determinado dia, Sofia atrasou-se cerca de vinte minutos, o que levou a coordenadora a assumir a aula da quinta série. Esta resolveu, então, verificar o conteúdo que vinha sendo trabalhado e notou várias páginas em branco nas apostilas de alguns alunos. Notou, também, que não houve correção de exercícios anteriores. Quando Sofia chegou à sala de aula, a coordenadora Cecília iniciou a discussão:

Cecília: A Bianca diz que tem dúvida... não sei se você corrigiu oralmente.

Sofia: Muitos exercícios eu faço correção oral e VOU continuar fazendo.

A coordenadora começa a colocar na lousa a correção dos exercícios. Sofia alega que já foi feita a correção:

Sofia: Mas você está colocando [na lousa] o que já foi corrigido?

Cecília: Pois é... mas eles não têm. Está errado. ((referindo-se aos alunos)): já copiaram lá? Já copiaram exatamente como está na lousa? A professora disse que fez a correção na lousa... não to entendendo...

A': Ela fez oral.

Cecília: Mas vocês não aprenderam a perguntar quando tem dúvida?

Nesse instante, Sofia deixa a sala de aula, assumindo a coordenadora:

Cecília: Vamos para o oitavo exercício...Vamos voltar para a página 38.

RÁPIDO! ... Tão conseguindo? Você tá conseguindo fazer?

A'': Eu to perdido.

Cecília: Então todos quietos que eu vou repetir só pra ele. 
Após trinta minutos, a coordenadora deixa a sala. Alunos começam a dispersar e, muito surpresos, entreolham-se. Um deles comenta: “A Cecília tá louca?” O desabafo de Sofia, em tom de irritação e cansaço logo após o episódio acima descrito, resume o quadro que vivenciamos:

Sofia: "Olha... ou eu trabalho como secretária ou eu dou aula... tem duas:: três:: quatro:: cinco:: seis apostilas e eu NÃO tenho tempo de fazer isso agora. ((refere-se às apostilas que a coordenadora colocou sobre a mesa para que ela corrigisse) )... desde o começo do ano eu ainda não consegui dar a aula que eu queria por motivos independentes da minha vontade... inclusive o Homo Sapiens veio aqui na sexta passada numa reunião e disse que eu não preciso colocar toda correção na lousa... porque é inglês instrumental... ((voltando-se aos alunos)): eu NÃO vou colocar na lousa... a Cecília mandou... MANDOU colocar na lousa mas eu NÃO VOU colocar na lousa porque vocês têm lá em cima - é cópia... olhem em cima do enunciado porque na prova a teacher não vai poder falar... então vocês vão ter que olhar e colocar... ((referindo-se novamente a mim)) se eu faço correção na lousa eles estarão fazendo cópia NÃO É ISSO QUE EU QUERO... nós estamos fazendo juntos... na correção oral eles têm que ter o discernimento para fazer os exercícios.

Apesar de longo, julgamos pertinente transcrever esse episódio na medida em que revela uma série de questões atualmente postas sobretudo pelas pesquisas na área de formação de professores. A principal delas diz respeito ao sentido hoje atribuído ao professor diante de suas condições objetivas de trabalho e das próprias políticas educacionais cada vez mais condizentes com o ideário neoliberal (Fernández Enguita, 1995; Franchi, 1995).

Ao expressarem cansaço e insatisfação diante do que lhe é exigido em termos de escolha metodológica e obrigações de caráter burocrático, como o cumprimento sistemático do conteúdo das apostilas, as anotações nas agendas dos alunos e ainda correções individuais, tanto Sofia quanto Aida nos remetem ao que Contreras (2002) chama de proletarização docente ou autonomia perdida, pautado na volta à racionalização e monitoramento do trabalho do professor.

Embora situada na esfera do ensino privado, as experiências de Aida e Sofia parecem muito articuladas a esse processo de desqualificação docente e perda da legitimidade do trabalho do professor diante de mecanismos controladores tipicamente postos pelas sociedades neoliberais, dentre estes o sistema de parcerias entre colégios. A perda de 
autonomia dá-se na medida em que o professor passa por um processo semelhante à alienação do sujeito no limiar da revolução capitalista em que o artesão, tendo seu trabalho outrora reconhecido por ele mesmo, passa a ser um operário em cujo produto não mais se reconhece. ${ }^{20}$ A perda de autonomia de que trata Contreras (op.cit.) torna-se evidente quando Sofia, em tom de lamentação, reclama sobre a falta de possibilidade de diálogo diante das exigências postas pelo colégio Áureo e/ou sistema Homo Sapiens:

Sofia: no começo do ano eu não estava bem... ( ) assim mesmo eu devo ter faltado ao todo do ano umas quatro vezes... então eu tenho isso comigo... não é fácil levantar às cinco horas da manhã... adoro dormir...tem dias que eu venho muito mais animada...é óbvio... tem dias que eu to com vontade/não é brigar... mas eu to com vontade acho que até de contestar algumas coisas...não é... trocar idéias e tal... agora depende também do retorno senão a gente acaba perdendo a motivação...

Das implicações desse quadro, muitos professores acabam desistindo de lecionar em determinadas instituições ou até mesmo procurando outros trabalhos. Embora se mostre apaixonada pelo que faz, a idéia de abandonar parcialmente suas obrigações no colégio Áureo não é descartada por Sofia ${ }^{21}$ :

Sofia: eu cheguei a pensar em... ai meu Deus...será que eu largo? será que eu fico só no Médio e tal? porque eu fiquei no começo/você ainda estava aqui... então sabe eu começo a ficar pressionada de uma coisa que eu perco a minha liberdade... então quando eu to muito desmotivada alguma coisa me pega...talvez eu saia daqui... você também é professora você vai saber o que que é isso....

A realidade observada em ambos os colégios é a realidade de muitas outras instituições de ensino básico, tanto públicas quanto privadas, que recorrem a parcerias com empresas na busca de qualidade educacional (Sousa, 2000). Esse "entrelaçamento de instituições" via parcerias, prática intensificada desde os anos 90 e mais recentemente visto na educação pública é um dos reflexos da nova configuração do Estado neoliberal, em que a relação entre indivíduo, sociedade e mercado passa a ser muito mais estreita, sobretudo por influência deste último.

\footnotetext{
${ }^{20}$ A idéia de alienação posta aqui diz respeito ao indivíduo que não mais se pertence e que não detém o controle de si mesmo, este sendo assumido por outrem. (Japiassú e Marcondes, 1996)

${ }^{21}$ Em novembro de 2006, soubemos que Sofia, de fato, parou de lecionar no Colégio Áureo.
} 
Segundo análise de Catani e Oliveira (2000), as reformas dos anos 90 trouxeram uma redefinição no papel do Estado na medida em que este concede autonomia e flexibilização aos diversos órgãos públicos e, paralelamente, utiliza-se de mecanismos de controle dessas mesmas instituições. Esse redimensionamento da polaridade centralização - descentralização do Estado, característico do modelo de Estado neoliberal, acaba por redefinir a função da educação, que hoje provém de uma agenda mundializada muito mais incisiva se comparada a décadas anteriores (Oliveira, 2000).

Das caracterizações dessa nova agenda da educação, Gentilli (1999) destaca a ênfase a aspectos tipicamente tratados no campo econômico, como a qualidade, a excelência, a produtividade e a eficiência.

Os próprios investimentos de organismos internacionais evidenciam o interesse em financiar projetos educacionais voltados para o desenvolvimento econômico. O próprio fato de agências multilaterais, como o Banco Mundial, priorizarem financiamentos em educação básica, por exemplo, é um forte indício da caracterização da escola como a instância responsável pelo desenvolvimento de habilidades que capacitem os indivíduos a concluir tarefas em prol do desenvolvimento do país, na medida em que, tal como argumentam, a melhoria da qualidade do ensino básico leva à melhoria de qualidade de vida das famílias e, por conseqüência, a uma maior produtividade econômica (Carnoy, 1992, apud Oliveira \& Fonseca, 2001).

Gee (2004: 109) também promove a crítica da ênfase ao ensino básico, mas sua reflexão vai além na medida em que ressalta seu caráter excludente, sobretudo com relação aos menos favorecidos:

(...) the recent standards, testing, and accountability regime has committed schools to supplying all children, especially poor children, with no more (and no less) than the basics'. This of course fits perfectly with the neoliberal philosophy that underlies the new capitalism.

Essa ênfase atribuída pelos organismos internacionais à educação básica e corroborada nas políticas educacionais de diversos países como forma de preparar indivíduos para o mercado parece evidenciar o que Afonso (2000) chama de mercadorização da 
educação ${ }^{22}$. Segundo o sociólogo português, trata-se da interpenetração de elementos do Estado e do mercado nas decisões voltadas à educação. Nesse contexto, o pesquisador vê a ameaça de valores como justiça, cidadania e igualdade em contrapartida ao apelo crescente de práticas que objetivam "excelência, eficácia, eficiencia, competitividade, produtividade e outros aspectos do campo da racionalidade econômica."

Desse modo, os colégios Teorema e Áureo parecem condizer com os preceitos do modelo neoliberal de educação justamente por importar elementos mercantis para as suas realidades. A própria caracterização de escola-parceira parece evidenciar o apreço da escola à qualidade de ensino atrelada à eficiência, ou seja, contratam-se os serviços terceirizados de assessoria pedagógica como forma de otimizar os processos educativos. Como se não bastasse, a proposta pedagógica do Homo Sapiens volta-se para a formação de indivíduos competentes para o mercado de trabalho, conforme ilustram os excertos anteriormente citados.

A recorrência das escolas públicas e até privadas à mobilização da sociedade via implantação de mecanismos de gestão ou provisão de recursos financeiros, materiais ou humanos (Sousa, 2000) constitui-se hoje, portanto, um dos desafios a se enfrentar. Um dos principais motivos dessa preocupação diz respeito justamente ao papel do professor e as implicações quanto às alterações de identidade que este vem sofrendo (Pimenta, 2005), conforme já tratamos anteriormente.

Apesar de ambos os colégios serem escolas-parceiras do mesmo sistema de ensino, é curioso notar as diferenças de posicionamentos de Aida e Sofia, havendo espaço para afirmarmos que o poder de agência, quando existente, acaba por 'alterar' ou 'subverter' o papel do professor enquanto mero executor de tarefas, tal como pretende o modelo neoliberal de ensino.

Um exemplo disso refere-se à forma como as professoras vêem a questão da falta de tempo: enquanto Aida lamenta o escasso número de aulas para cumprir o programa do sistema Homo Sapiens ("mas o problema é que eu acho que poderia ter MAIS aulas...

\footnotetext{
${ }^{22}$ Alguns autores, ao problematizarem o mesmo assunto, utilizam o termo quase-mercado (Sousa e Oliveira, 2003).
} 
pra gente poder sabe? Enunciar mais os conteúdos...”), Sofia lamenta a falta de tempo para continuar desenvolvendo seus projetos em grupo. Em outro momento da entrevista, a professora trata dessa questão:

Sofia: eu acho que eu to conseguindo praticamente dar tudo né/passando por tudo... só que aí eu parei algumas coisas que eu fazia... fazer os projetos principalmente com a quinta série...

Diante de nossas observações de aulas, percebemos que Sofia, ao contrário de Aida, passava várias aulas sem utilizar a apostila, tamanho era seu envolvimento com os projetos em grupo, cujos temas não se articulavam necessariamente com o conteúdo do método de ensino. Essa atitude de Sofia demonstra que a professora assume os riscos e toma para si o direito de decidir em SUA sala de aula. Sofia, ao fechar a porta, sabe que a sala é sua e, por cinqüenta minutos, suspende as exigências burocráticas e subverte a ação pedagógica que lhe é posta.

Das evidências para essa análise, podemos retomar o episódio do atraso da professora, em que a coordenadora Cecília assumiu a aula e iniciou uma correção de exercícios na lousa. Logo que a coordenadora deixou a sala, Sofia disse: “Eu NÃO vou colocar na lousa... a Cecília mandou... MANDOU colocar na lousa mas eu NÃO VOU colocar na lousa porque vocês têm lá em cima - é cópia...”. Em outro dia de aula, o mesmo poder de agência pôde ser notado quando Sofia permitiu que os alunos se sentassem ao chão para o desenvolvimento de um projeto em grupo, mesmo diante da proibição da coordenadora.

Um outro aspecto interessante para a análise diz respeito ao posicionamento de Sofia diante do sistema Homo Sapiens. Embora se mostre adepta da abordagem construtivista e contrariada com as exigências quanto ao cumprimento do programa, podemos dizer que a professora busca respaldo no sistema ("inclusive o Homo Sapiens veio aqui na sexta passada numa reunião e disse que eu não preciso colocar toda correção na lousa... porque é inglês instrumental...") na tentativa de construir contra-argumentos diante de seus embates com a coordenadora do colégio. Sua simpatia oscilante, provisória e conveniente pelo sistema apostilado faz ressoar as contradições de que havíamos mencionado como possibilidade na construção das narrativas dos sujeitos de pesquisa e da forma como estes lêem sua própria prática. 
Os diferentes posicionamentos de Sofia parecem remeter ao conceito de narrativa proposto por Brunner (2001). Contrapondo-se ao pensamento linear de caráter técnicocientífico, o autor descreve o pensamento narrativo de natureza social, processual, donde as verdades do modelo linear cedem lugar à noção de plausibilidade ${ }^{23}$. As narrativas são, dessa forma, processos de significação socialmente construídos, sendo influenciadas por "circunstâncias culturais e históricas" e imbuídas de crenças, valores, desejos (Brunner, op.cit: 131), donde se pode traçar um paralelo entre tais "circunstâncias culturais" de que trata Brunner e as diferentes circunstâncias do entorno de Sofia: seus alunos, a coordenadora, o sistema Homo Sapiens, a própria Sofia.

A nosso ver, trata-se de uma curiosa e contraditória construção de narrativas na medida em que Sofia, quando se posiciona perante o Homo Sapiens, por exemplo, exalta a qualidade das apostilas, mas em seguida revela um tom nostálgico ao narrar o tempo em que o colégio costumava adotar livros-textos de inglês, tal como deixa transparecer na fala seguinte, em que pedimos ao leitor atenção aos trechos em negrito:

((bom... essa idéia da apostila você concorda com a proposta... de trabalhar com a apostila?))

Sofia: concordo... com certeza... a apostila Homo Sapiens pro Médio/tem 3 anos que eu to aqui... mas aqui é diferente... a proposta é diferente... o conteúdo é diferente e como você vai passar pros alunos... porque o Homo Sapiens é a revisão de tudo...

((comparando o trabalho com o livro e com a apostila quais são as vantagens e quais são as desvantagens...?))

Sofia: quando eu estava indo com eles (com o livro) tava bárbaro... tinha esses projetos até ano passado... porque o Click-together tem um monte de projetos...

((gravação é interrompida momentaneamente. A professora mostra alguns livros para mim))

Sofia: então... você vai dar uma olhada e você vê que são ótimos... são bárbaros... porque tinha o texto:: eles liam:: (...) tinha revisões... a cada duas lições tinha a revisão e a cada bimestre tinha um projeto e eles adoravam porque tinha que apresentar...

((eles gostavam mais do livro do que da apostila na sua opinião? E você?))

Sofia: gostavam... e eu também... se bem que eu/eu acho que eu to conseguindo praticamente dar tudo né/passando por tudo... só que aí eu parei algumas coisas que eu fazia... pra fazer os projetos principalmente com a quinta série.

\footnotetext{
23 Palestra proferida por Menezes de Souza sobre "Narrativa e Identidade" em 17.08.2006 no Departamento de Letras Modernas da Universidade de São Paulo.
} 
Sobre o poder de agência identificado na prática pedagógica de Sofia, mencionamos as contribuições de Marcelo García (1999) que, embora inserido no âmbito das discussões acerca da formação de professores principiantes, elucida interessantes questões sobre as formas de integração do professor na sua cultura de ensino.

O autor, em referência teórica a Lacey (1977, apud Marcelo García, ibidem: 116) relata três estratégias utilizadas pelos professores em seus processos de integração, a saber, o ajustamento interiorizado, sem qualquer conflito entre professor e instituição; a submissão estratégica, pela qual o professor assume determinadas concepções da instituição, com certas ressalvas pessoais; e finalmente, a redefinição estratégica, em que o professor consegue provocar as transformações por ele almejadas perante a instituição.

Tendo em vista tais estratégias e considerando a concepção de educação de Sofia e a forma como ela lida com as concepções do Colégio Áureo e do sistema Homo Sapiens, podemos dizer que a professora pratica uma submissão estratégica, cuja definição em Marcelo García (ibidem: 116) convém transcrever:

(...) é a estratégia de socialização utilizada quando os professores reconhecem publicamente e assumem as concepções e valores das pessoas que representam a autoridade, mas mantém certas reservas pessoais e privadas face a tal definição.

Assim, Sofia publicamente aparenta manter concordância diante do que lhe é posto em termos de concepções de ensino, mas possui ressalvas na medida em que lamenta a dificuldade em desenvolver projetos construtivistas, utilizando-se, com isso, de seu poder de agência ao fechar a porta de sua sala de aula.

Diferentemente de Aida e Sofia, Beatriz, a professora da EMEF dispõe de maior autonomia no processo de definição do conteúdo curricular de sua disciplina (nós decidimos em conjunto aqui na escola... o que nós achamos mais convenientes ta passando pros alunos.. é... o conteúdo a gente que define... a gente escolhe o tempo verbal e vamos trabalhando o que pode causar interesse pra eles né...). Além disso, percebemos a autonomia para trabalhar com os alunos de acordo com seus ritmos, 
fazendo jus à "pedagogia do parar" ${ }^{24}$ vinculada à superação da não-aprendizagem (Vasconcellos, 2003: 55):

Beatriz: Vamos continuar estudando esse esquema até o final do ano porque muitos tiveram problemas.

Ou ainda num outro dia de aula em que a professora diz:

Beatriz: Hoje eu vou fazer uma revisão de perguntas e respostas de novo... porque a maioria não tirou nota na última atividade... então eu vou passar também um trabalho individual para fazerem...

Sua narrativa revela-nos a possibilidade de autonomia em sala de aula e de trabalho coletivo entre as professoras de uma mesma área, prática desejável em qualquer contexto educacional como um dos elementos essenciais para o desenvolvimento profissional e revalorização docente (Contreras, op.cit; Pimenta, op.cit). Trata-se de um quadro absolutamente distinto daquilo que vivenciamos nos colégios Teorema e Áureo, muito em função da liberdade de ação e maior poder de agência que o ensino público possibilita ao educador, ao menos nesta EMEF especificamente.

A análise dos três contextos observados certamente pode ser expandida diante da investigação específica sobre a concepção de avaliação das participantes da pesquisa bem como os procedimentos avaliativos de que se utilizam. É o que será focalizado no capítulo subseqüente.

\footnotetext{
${ }^{24}$ Em oposição ao ensino conteudista em que professores preocupam-se apenas em cumprir o conteúdo, não havendo tempo para parar e discutir os assuntos com os alunos, solucionando possíveis dúvidas.
} 


\title{
2. Problemas da avaliação da aprendizagem no paradigma da modernidade
}

\author{
Fortemente influenciada pela \\ psicologia comportamental e cognitiva \\ predominante, a teoria educacional tem \\ sido construída em torno de um discurso e \\ conjunto de práticas que enfatizam \\ aspectos metodológicos imediatos e \\ mensuráveis da aprendizagem. \\ HENRY GIROUX (1997)
}

\subsection{As bases epistemológicas constituintes da avaliação}

Segundo Worthen e Sanders (2004), as primeiras manifestações formais de avaliação de que se tem registro remontam a 2000 a.C, época em que governadores chineses já aplicavam provas a servidores públicos no intuito de medir seus desempenhos. Na Grécia Antiga, filósofos utilizavam-se de avaliações verbais para a verificação da aprendizagem de seus discípulos. Em meados do século XVII, quando do desenvolvimento das ciências naturais, houve maior necessidade de observar aspectos sociais, como saúde e população; em decorrência desses levantamentos quantitativos, as formas de avaliação começavam a ganhar espaço.

Embora esses fatos históricos constituam interessante leitura, nosso enfoque encontra-se a partir do início do século XX, por tratar-se de um momento decisivo na consolidação da educação formal tal como a conhecemos hoje e especificamente na constituição da avaliação educacional.

Isso porque nos primeiros anos do século $\mathrm{XX}$, os avanços nos estudos de caráter biológico trouxeram grande influência para o campo educacional, que, caracterizado como campo heterônomo, buscou no cientificismo a legitimação de suas práticas. Ao caracterizar a educação como ciência do comportamento, portanto, menos verificável do 
que as ciências físicas, Huberman (1973) corrobora a idéia de maior heteronímia dentre os agentes do campo educacional e essa necessidade outrora posta de legitimar-se via estudos científicos.

Em conseqüência disso, a educação sofreu forte influência da filosofia positivista do século XIX, cuja origem encontra-se vinculada ao emergente cientificismo daquela época, caracterizando-se essencialmente pela ênfase à experimentação e observação de fatos de forma lógica, racional e concreta e ainda pelo desejo de organização social prescrita por uma 'doutrina do dever para com todos', a qual se sustenta na representação da sociedade como um organismo composto harmoniosamente (Japiassú e Marcondes, 1996). No que diz respeito aos estudos em avaliação educacional especificamente, tal influência positivista pôde ser notada diante da predominância de pesquisas de caráter psicológico, voltadas sobretudo ao campo da Psicometria, definida como a ciência que procurava medir com precisão as capacidades intelectuais do homem.

Além da influência dos fundamentos psicológicos, convém assinalar que a concepção de educação, e conseqüentemente de avaliação, do século XX também abarcou influências do setor industrial. Conforme historiciza Vianna (1995), a avaliação educacional herdou três elementos essenciais do gerenciamento industrial tipicamente postos nos primeiros trinta anos do século XX, a saber, a sistematização, a padronização e a eficiência. ${ }^{25}$

Destarte, as primeiras décadas do século XX são marcadas pela ênfase à investigação sobre mensuração de capacidades via testagem, a exemplo do movimento denominado Measurement Movement, o qual propunha medir precisa e objetivamente as mudanças ocorridas nos seres humanos durante o processo de aprendizagem.

A concepção de educação sustentada por esse movimento revela um teor normativo e positivista, na medida em que atribui à educação o papel de produzir e controlar as mudanças nos indivíduos em prol do bem-estar geral. Em sendo a educação a mola propulsora de mudanças nos indivíduos de forma a produzir o bem-estar social, havia a

\footnotetext{
${ }^{25}$ Tais elementos acabaram sendo revisitados na trajetória dos estudos em avaliação alguns anos mais tarde, com destaque para dois principais momentos: a educação tecnicista da década de 60 e as influências neoliberais para o campo educacional observadas sobretudo a partir dos anos 90 .
} 
necessidade de medir a ocorrência ou não de tais mudanças de maneira altamente objetiva e precisa, livre de interpretações ou julgamentos subjetivos:

(...) We may expect (...) that in education, as in other sciences and in personal endeavors, the more objective, clear-cut, and refined the measures of educational products are, the greater are the possibilities of determining and putting into effect improved educative procedures.

(Thorndike e Gates, 1931: 286)

Apesar de reconhecer a impossibilidade de medir precisamente muitas das reações humanas, Thorndike, principal representante do Measurement Movement, e outros pesquisadores da época priorizavam a adoção de instrumentos que pudessem reduzir ao máximo a subjetividade. Nesse sentido, os testes objetivos até então utilizados no setor militar e industrial norte-americano, acabaram propagando-se para o campo educacional sob a forma de testes para medir o aprendizado.

Conforme explica Broadfoot (op.cit.), o crescimento da divisão do trabalho conseqüente do processo de industrialização demandou a necessidade de definir mecanismos de controle social, uma vez que novos papéis surgiam e precisavam ser alocados. A avaliação formal foi a solução encontrada para esse controle na medida em que constituía a maneira mais "válida e justificável" para legitimar as competências dos indivíduos. É importante ressaltar que o processo de demonstração de competências era permeado por uma competição tida como "justa", “aberta” e, por isso, incontestável, já que os mecanismos formais de avaliação eram cientificamente embasados. Inauguravase, pois, uma fase de seleção, certificação e controle social permeada pela competição, donde as avaliações formais, em especial o uso de testes escritos, assumiram destaque.

É importante esclarecer que o desenvolvimento da avaliação iniciou-se por estudos voltados à avaliação de programas que não necessariamente articulados com a educação. Mais tarde, essas contribuições fizeram-se presentes no e adaptadas ao campo educacional, como destaque para a avaliação da aprendizagem. 


\subsubsection{Problema 1: Avaliação como sinônimo de mensuração}

Uma das implicações desse movimento norte-americano para as concepções de avaliação subseqüentes constitui a conceituação de avaliação como sinônimo de mensuração. Uma vez engendrada pelo viés psicológico, a avaliação inicialmente era vista como disciplina docimológica ${ }^{26}$, permitindo, assim, que se confundisse avaliação com processo de medida.

De acordo com Vianna (1997), o conceito de avaliação enquanto sinônimo de mensuração é ainda bastante presente nos diferentes contextos educacionais brasileiros. Isso pôde ser evidenciado nas narrativas de alguns sujeitos de pesquisa, tal como o seguinte trecho referente ao dia posterior à aplicação da prova elaborada por Aida:

A1: Professora você já corrigiu as provas?

Aida: Sim:: eu corrigi as provas

A1: Por que que você não trouxe elas?

As: Ahhh ((desapontados))

Aida: Essas provas só serão entregues na reunião dos pais, que vai ser no próximo sábado.

A2: Fala a nota.

As: É... fala a nota.

Aida: As notas eu posso falar.

A preocupação de Aida parece muito voltada ao cumprimento do programa, não lhe restando tempo para dialogar com os alunos sobre o desempenho que tiveram nas provas como mecanismo de redirecionamento de sua prática (Vasconcellos, op.cit.). Ao contrário, há prioridade quanto ao ato de informar aos alunos o resultado da medida de seus aproveitamentos, no caso, a nota, e juntamente com esta o julgamento implícito de aprovação ou reprovação de cada um deles. Os próprios alunos também demonstram interesse na informação de resultados per se, corroborando a conceituação de avaliação como sinônimo de mensuração, tamanho o interesse e expectativa da turma em tomar conhecimento da nota que haviam obtido naquela prova:

Aida: (...) Então tá. Gabriel, oito vírgula oito na prova, sete e meio de média.

Gabriel: tem certeza que você não falou errado, profa?

\footnotetext{
${ }^{26}$ Do termo docimologia, "estudo dos exames", donde $\operatorname{docim}(o)$ significa prova, tentativa, experiência.
} 
Aida: Você é o Gabriel A... O.... ? ((Aida fala o nome completo do A)). Oito vírgula oito na prova... Foi você mesmo, de verdade. ((Aida vira-se para mim e comenta, aos risos)): Ele não tá acreditando

Aida: Isabela, você tirou dez na prova, e ficou com dez na média.

As: [uhuhu!!!] (As fazem barulho reagindo ao ouvirem tais notas)

Aida: Marina, dez na prova, nove e meio na média.

Aida: Quem não conseguiu terá outra oportunidade... Eu espero que saiam do meio ponto.

((a aula prossegue com exercícios na apostila)).

Embora inserido na discussão acerca do aspecto quantitativo da avaliação, o excerto acima remonta às idéias de Bourdieu (1996) sobre os ritos da consagração. Trata-se das condições em que um sujeito autorizado em sua comunidade utiliza-se de seu poder para sancionar ou não determinadas ações em seu entorno. Aida, então, parece exercer a função do professor como porta-voz autorizado, na medida em que sua fala é imbuída de capital simbólico, reconhecido e legitimado por seus alunos.

Em termos gerais, ao definir os rituais da magia social como "todo o conjunto de condições que possibilitem a realização eficaz dos atos de autoridade ou atos autorizados", Bourdieu (op.cit.: 89) nos possibilita afirmar que a avaliação situada no paradigma da modernidade constituiria a condição por excelência para a realização dos atos de autoridade do professor. Ousamos dizer que a avaliação per se constituiria o próprio ritual, já reconhecido pelos alunos.

O próprio sistema de parcerias entre o Colégio Teorema e o sistema Homo Sapiens acaba por corroborar o entendimento de avaliação como mensuração na medida em que prioriza o aspecto quantitativo, conforme deixa transparecer o depoimento de Aida:

Aida: Então, é um sistema que dá certo... né? embora muitas vezes a gente tem aqui mesclar muito essas avaliações contínuas mesmo porque muitas vezes não reflete o aproveitamento do aluno (...) agora em relação a corrigir realmente... dá um trabalhão... porque eu por exemplo que tenho TODOS os alunos da escola né? chega a ter três mil e poucas provas, e provas de uma forma geral, a contínua, mensal, bimestral é ... por bimestre... então assim é o tempo todo corrigindo, fazendo...

A mesma ênfase ao caráter mensurável da avaliação pôde ser depreendida na prática avaliativa de Sofia, cujas narrativas em que trata da avaliação especificamente mais uma vez se mostraram inconstantes. Essa leitura encontra respaldo logo em meu primeiro 
contato com Sofia. Ao chegar na sala de aula, os alunos perguntam sobre mim; apresento-me como professora e aluna. A professora complementa, referindo-se à minha coleta de dados para esta pesquisa:

Sofia: E isso que ela tá fazendo vale uma nota, sabiam?

Seu entendimento de avaliação como mensuração também é evidenciado quando a professora descreve o sistema avaliativo do colégio Áureo:

Sofia: No fundamental, a avaliação ela tem, são três atividades avaliativas de zero a nove e com mais um ponto de participação, né? E a prova bimestral que é... marcada pela escola, todos sabem o dia, o horário, e é peso dois. Nós somamos essas três notas de mensal, dividimos por três e verificamos se vale (hum)... se o aluno merece o ponto ou não.

((Isso no Ensino Fundamental? Três provas por mês e uma...))

Sofia: e um ponto de participação. E uma bimestral, tá? A cada bimestre é... avaliando o todo, né? Toda a matéria. Porque às vezes a mensal eu faço meio separado, né? Primeiro eu dou uma matéria, dou alguma coisinha, e aí então eu avalio...

((Qual que é o peso da mensal?))

Sofia: peso 1 (um)... Divide por três, porque no final ela é uma média ponderada, então eu vou dividir tudo por três. Então a média que eu tiro das três notas da prova mensal eu divido por três e um ponto que eu vou discriminando. Por exemplo, um aluno tirou nove de média, se ele foi bem em todas as provinhas, nos trabalhos, nos projetos, em tudo o que eu faço, ele merece um ponto porque ele é bom aluno o tempo todo, ele vai com média dez na mensal... Só que aí ele tirou seis na prova bimestral, então eu multiplico o seis por dois, somo o dez que ele teve na mensal e divido por três.

Conforme podemos inferir, o fato da professora relatar longa e detalhadamente os procedimentos de atribuição de tais notas demonstra a preocupação com o produto final em detrimento do processo.

Sentindo a necessidade de averiguar com maior afinco o conceito de avaliação para Sofia, resolvo perguntar-lhe diretamente acerca do assunto. Sua resposta corrobora a interpretação de que a professora entende avaliação como sinônimo de mensuração:

((se você fosse resumir... você avalia o seu aluno pra quê?))

Sofia: ((a professora parece não entender a pergunta, a qual está voltada ao propósito da sua prática avaliativa)) a nota? Você quer dizer a nota? ((não... mas é... o que seria o avaliar...)) 
Sofia: é ((termo não compreendido. Sofia parece referir-se novamente ao conceito de cognitivismo/construtivismo))... porque a avaliação cognitiva né...veja bem... eu não vejo pela nota...de forma alguma... agora eu vejo como uma competição de mais de menos... porque aí o que que acontece/ tudo na vida da gente é uma competição né? e a gente foi criado assim né?

((no caso, você avalia o aluno pra ou aprovar ou reprovar?))

Sofia: ( ) muito raramente...

Recorrendo ao trecho da entrevista com Sofia, percebemos que a professora faz menção à "avaliação cognitiva", mas não explicita o seu entendimento quanto ao conceito. Acreditamos que tal menção tenha relação com sua preferência pela abordagem construtivista, tão recorrente em suas narrativas. De qualquer forma, Sofia volta a contradizer-se quando se refere à competição. $\mathrm{O}$ ato de competir implica vencedores e perdedores, donde em avaliação poderíamos fazer a correlação para "aprovados e reprovados". A partir do momento em que Sofia pressupõe a competição inerente às relações sociais, sua representação de avaliação revela naturalmente um teor classificatório calcado na distribuição de notas.

A representação da avaliação como mensuração tanto de Aida quanto de Sofia também pode ser depreendida ao considerarmos as "orientações para se fazer uma boa avaliação" prescritas logo na primeira página das provas tanto do colégio Teorema como do Áureo (vide Anexos 4, 5, 6, 7 e 8). São estabelecidas normas de caráter autoritário e punitivo, como a proibição de quaisquer rasuras nas questões de múltipla escolha, a habitual regra do uso de caneta azul ou preta e até mesmo a obrigatoriedade de se "escrever bonito", das quais é possível inferir a preferência pela objetividade em detrimento das múltiplas e subjetivas leituras e interpretações que uma "letra feia" poderia oferecer. As orientações do Colégio Áureo vão além da representação de avaliação como mensuração na medida em que sugere que o aluno expresse sua aprendizagem "de forma clara, organizada e completa" 27 , mostrando-se vinculadas à filosofia positivista e ao desejo de totalidade e completude posto pela Modernidade.

Essa excessiva importância atribuída à medida e objetividade do processo avaliativo parece ser uma das razões para o atual uso do termo assessment, em inglês, como sinônimo de evaluation. Conforme relata Broadfoot (op.cit: 06), enquanto o termo

\footnotetext{
${ }^{27}$ Grifos contidos na prova.
} 
assessment refere-se à medida deliberada do desempenho educacional com a finalidade de fornecer informações para propósitos que vão além da situação imediata de aprendizagem, o conceito de evaluation abarca a interpretação ou o julgamento de tais informações. Assim, em sendo a subjetividade rejeitada em detrimento da prioridade de instrumentos estritamente objetivos, o ato de avaliar passou a ser sinônimo de ato de medir.

Na literatura brasileira, Luckesi (2003: 87) traz uma discussão similar ao dicotomizar os termos 'verificação' e 'avaliação', mostrando que o primeiro, do latim verum facere, significa 'buscar a verdade de algo', enquanto que o segundo, advindo do latim $a$ valere, implica uma tomada de posição em relação ao objeto avaliado. Sob essa ótica, o autor ressalta que a avaliação da aprendizagem requer, num primeiro estágio, a verificação ou a medida do desempenho, mas seu sentido em essência constitui a interpretação e o uso que será feito diante dos resultados identificados. Machado (2002: 72), por sua vez, corroborando as definições de Luckesi (op.cit.), diferencia os termos 'avaliar', evaluate e assess e conclui:

Embora a idéia de avaliar inclua a de calcular, computar, determinar o preço, expressar numericamente ou expressar o valor matemático de algo, em seu cerne encontra-se, sem dúvida, a idéia de valor.

Ao mesmo tempo em que Aida parece priorizar o caráter mensurável da avaliação, chamou-nos a atenção a freqüência com que a professora mencionou o termo avaliação contínua. A seguir transcrevemos alguns desses momentos:

Aida: Porque é assim... vocês têm a nota da contínua:: que é uma média de contínua que aliás eu já até fechei... a mensal e a bimestral

Aida: hoje nós faremos uma atividade contínua... com o dicionário.

Aida: por exemplo nós trabalhamos árvore genealógica... então uma avaliação contínua que eu dei foi pedir que eles fizessem a árvore genealógica da família deles e em cima da árvore deles fizessem as frases usando genitivo, e o que eles ficaram vendo na apostila, né...o grau de parentesco 
Aida: entrego pro aluno as contínuas, as mensais são entregues pros alunos... as bimestrais a gente entrega na reunião... pros alunos que os pais não vieram à reunião então aí a gente entrega a prova pro aluno mesmo...

Do conceito de avaliação contínua, inclusive adotado na legislação educacional brasileira desde a Lei de Diretrizes e Bases 9394/1996, mencionamos a definição de Sacristán (2000: 347), cujo conceito de avaliação contínua prioriza aspectos processuais na tentativa de promover uma maior inclusão social:

"A avaliação contínua tem coerência pedagógica só se a entendemos desde a perspectiva informal com fins formativos, realizada pelos professores dentro das práticas habituais de trabalho e acompanhamento de tarefas"

Bonniol e Vial (2001: 280) também fazem menção à avaliação contínua, enfatizando os propósitos que a permeiam:

(...) A avaliação torna-se contínua, como forma de pensar o trabalho a ser feito, enquanto ele é feito e depois de feito. Não se pretende mais que o critério seja uma norma a ser respeitada, mas torna-se uma ferramenta de trabalho, que pode ser melhorada, regulada e que evolui conforme a descoberta das noções que permite manipular.

Nesse sentido, questionamos até que ponto o conceito de avaliação contínua adotado por Aida reflete as representações descritas acima, na medida em que a professora se refere a essa forma de avaliação de maneira bastante pontual, depreendida inclusive por aspectos lingüísticos que não se mostram coerentes à idéia do "contínuo", como o uso de artigos definidos e indefinidos (a nota da contínua), de adjuntos adverbiais de tempo ("hoje”) e de verbos pontuais ("dar uma avaliação contínua”).

Isso remonta à preocupação de Vasconcellos (2003: 12) com os modismos em avaliação ao denunciar o uso desenfreado de termos novos (como é o caso do conceito de avaliação contínua) sem a devida reflexão crítica acerca da importância de se desenvolver um método de trabalho embasado numa determinada fundamentação teórica. Parece não ter havido uma mudança conceitual de avaliação por parte de Aida, pois mesmo sendo realizada com maior freqüência, ainda assim é essencialmente 
caracterizada enquanto mecanismo de mensuração. O próprio Vasconcellos (ibidem: 124) afirma que "muitos professores consideram que mudaram totalmente seu processo de avaliação só porque agora fazem 'muitas' avaliações”.

Além da ênfase ao aspecto mensurável no processo de significação da avaliação, muito em função da influência de fundamentos psicológicos sobre os estudos educacionais, julgamos importante assinalar outros dois aspectos marcantes na constituição da avaliação da aprendizagem ao longo do século. Referimo-nos à prioridade com que determinadas categorias da avaliação têm sido tratadas, no caso, a prioridade dispensada ao longo de todo o século XX quanto ao conteúdo (o que avaliar) e à forma (como avaliar) da avaliação, negligenciando-se o por quê avaliar.

\subsubsection{Problema 2: A ênfase a conteúdos objetivos e estáveis}

No que diz respeito ao conteúdo que se quer avaliar, trata-se, a nosso ver, de um aspecto relacionado à área de conhecimento, definido com base nos conteúdos curriculares planejados no início do ano letivo.

Segundo Baxter (1997), essa questão pode parecer simples num primeiro olhar, mas não o é se considerarmos os vários aspectos que o ensino de línguas abarca, como por exemplo os aspectos lingüísticos, os diferentes usos da linguagem, as habilidades aprendidas no lidar com a linguagem e ainda outras habilidades sociais e comportamentais. Como, então, definir o conteúdo que se quer avaliar? $\mathrm{Na}$ visão do mesmo autor, dentre os inúmeros aspectos que poderiam ser avaliados, os professores de língua estrangeira têm priorizado aqueles considerados fáceis de serem ensinados e de serem pontuados. Um exemplo constitui a ênfase da avaliação de estruturas gramaticais, pois estas têm sido conceituadas como sistemas de regras fixas, com significados objetivos e estanques e, conseqüentemente, mais fáceis de serem medidos.

Vasconcellos (op.cit.) também problematiza essa questão ao tratar da primazia da avaliação cognitiva, a qual enfatiza tanto conteúdos quanto procedimentos, em oposição ao tratamento negligenciado a outros aspectos de ordem sócio-afetiva, igualmente relevantes na esfera escolar, uma vez que nela estão em jogo valores, 
hábitos, atitudes. A crítica que o autor (ibidem: 100) promove refere-se à avaliação de conteúdos descontextualizados por meio da fragmentação do saber.

Da análise dos instrumentos avaliativos desenvolvidos por Aida, é possível identificar essa ênfase à avaliação fragmentada de conteúdos. Podemos dizer que são testados conteúdos da língua memorizáveis e descontextualizados conforme evidenciam boa parte dos exercícios dos Anexos 4, 5 e 6.

No Anexo 4, por exemplo, são avaliados conteúdos gramaticais de forma abstrata e compartimentada. Além dos exercícios de que já tratamos no capítulo I, mencionamos o exercício 3, em que os alunos devem completar os espaços com o verbo To Be (Figura 8) em enunciados totalmente descontextualizados de sua situação discursiva, cuja abstração é ainda agravada pela utilização de elementos dêiticos (I, You, We, She):

3. Complete com o verbo To $\mathrm{Be}(\mathrm{am}$, is ou are) (1.0)
a-) I
b-) You from Brazil.
c-) We from England.
c-) She from United States.
d-) Peter a girl. a student.

Figura 8: exercício gramatical, com ênfase para o uso do verbo $T o$ Be, extraído do Anexo 4.

Na mesma prova, há também exercícios que testam a aquisição de vocabulário, como é o caso do exercício 8 (vide Anexo 4), que solicita os nomes dos continentes de acordo com um mapa, e ainda o exercício 9 (Figura 9), em que os alunos devem completar as frases, informando algumas localizações. Ambos os exercícios parecem, portanto, relacionados, numa tentativa de contextualizar o ensino do vocabulário em inglês ao conhecimento em outras áreas, como geografia:

9. Complete as frases (1.0)

a-) Brazil is located in

b-) Canada is located in

c-) Japan is located in

d-) Kangaroos are native to

Figura 9: exercício de vocabulário referente aos continentes, extraído do Anexo 4. 
No Anexo 5, o ensino fragmentado de conteúdos é evidenciado em exercícios que avaliam o aspecto lexical, como ocorre no exercício 8, que solicita o nome de quatro planetas do nosso sistema solar e no exercício 9, no qual os alunos devem encontrar o nome de quatro planetas em uma cruzadinha (vide Anexo 5). Infelizmente quando chegamos ao Colégio Teorema para a coleta de dados, a professora já havia trabalhado o tema com os alunos, o que não nos possibilita saber a forma com que ela o fez. A análise do exercício per se, no entanto, leva-nos a afirmar a ênfase ao ensino de conteúdos tidos como verdadeiros.

O Anexo 6 traz outras evidências da avaliação cognitiva descontextualizada, como o exercício 1, em que os alunos devem escrever os números por extenso; o exercício 7, no qual devem escrever as horas por extenso, e ainda o exercício 3 (Figura 10), em que se solicita a mesma tarefa, desta vez referindo-se a preços:

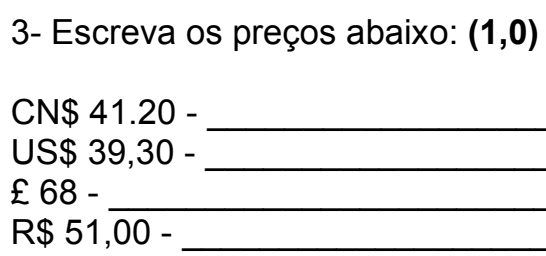

Figura 10: exercício de vocabulário referente a números e moedas, extraído do Anexo 6.

É interessante notar que o exercício faz referência a diferentes moedas estrangeiras, mas o faz de modo descontextualizado. Resta saber se os alunos entendem seus significados e ainda conseguem estabelecer a equivalência de seus valores com relação à moeda brasileira, o que significaria um ensino mais significativo. Esse, entretanto, não parece ser o objetivo do exercício na medida em que prioriza o vocabulário de números em sua forma escrita (spelling). Sob a perspectiva de uma pedagogia de letramentos, mais importante do que reconhecer a moeda e o valor constituiria saber o que se compra com as quantias indicadas nos respectivos países.

Outros exercícios da mesma prova continuam a enfatizar o conhecimento de conteúdos fixos, solicitando a versão e a tradução de vocábulos ou expressões isoladas, como o exercício 5 "Escreva em inglês o nome dos objetos abaixo", e o exercício 9 "Traduza as 
palavras abaixo", este último objetivando testar a aquisição de vocabulário referente a comida (vide Anexo 6).

As provas escritas elaboradas por Sofia (Anexos 7 e 8) também buscam avaliar conteúdos com significados objetivos e estáveis. No Anexo 7, por exemplo, o primeiro exercício apresenta um texto sobre Fred King, um ator americano; os alunos devem formular as perguntas de uma possível entrevista com o ator, cujas respostas já se encontram prontas. Não tivemos a oportunidade de verificar os critérios de correção de Sofia, mas o exercício parece testar o uso de Wh-words e a estruturação da forma interrogativa, com uso de verbos auxiliares, em concordância com o conteúdo da apostila. A maioria dos exercícios dessa prova apresenta o modelo de blank-filling, no qual a professora provê os vocábulos a serem utilizados corretamente pelos alunos, como é o caso dos exercícios 4 e 6 anteriormente transcritos (Figuras 5 e 6).

O Anexo 8 também prioriza a objetividade dos conteúdos, como é o caso do exercício 3, de que já tratamos no Capítulo I, e o exercício 5 (Figura 11), que testa o conhecimento de Wh-words:

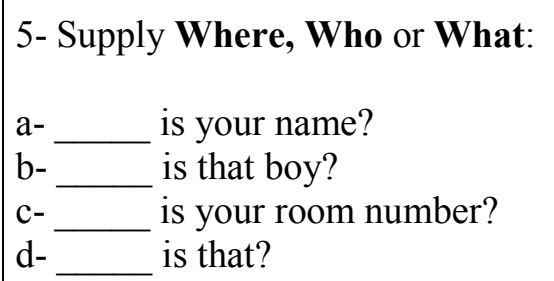

Figura 11: exercício referente ao uso de Wh-words, extraído do Anexo 8.

Apesar de não haver reprovação no decorrer de um ciclo com a recente implementação do regime de Progressão Continuada ${ }^{28}$ e, conseqüentemente, a ausência de prescrições do governo quanto à sistematização da avaliação, Beatriz também faz uso de provas escritas. Tais exercícios avaliativos também priorizam conteúdos lingüísticos:

Beatriz: please... por favor...hoje vocês vão fazer uma atividade que vai valer nota. Vocês vão pegar uma folha de caderno, tirar o pedaço de espiral e me entregar. É das perguntas e respostas. Eu quero saber o que cada um

\footnotetext{
${ }^{28}$ Lei de Diretrizes e Bases 9394/96.
} 
aprendeu... não precisa fazer a capa. Eu vou colocar as frases em inglês e a tradução mas vocês coloquem as respostas em inglês.

A preparação das provas por Aida e Sofia parece estar de acordo com os objetivos do curso previamente estabelecidos no início do ano letivo. Em nossa leitura, isso remete à influência de Tyler (1949), um dos pesquisadores mais influentes nos estudos sobre currículo e avaliação do século XX. Tyler propõe a definição de planos seqüenciais de instrução que explicitassem as etapas da aprendizagem. Trata-se da ênfase ao estabelecimento de objetivos educacionais na medida em que estes determinam os materiais, o conteúdo, os procedimentos de ensino e a avaliação. Tais objetivos são distribuídos linear e hierarquicamente conforme graus de dificuldades, cabendo ao professor avaliar se os seus alunos atingiram tais objetivos. A linearidade com que Tyler trata a questão do conhecimento pode ser depreendida quando o autor (ibidem: 35) refere-se, por exemplo, à questão da leitura, evidenciando as influências da filosofia positivista em educação:

(...) enquanto não se houver atingido um nível de competência na leitura que inclua um vocabulário básico bastante bem assimilado, é inútil dar muita atenção ao desenvolvimento de aptidões de interpretação crítica e cuidadosa.

Conforme Álvarez Méndez (2002), a influência positivista na educação assume uma concepção prescritiva do conhecimento, o qual é transmitido por meio de uma "pedagogia por objetivos" de caráter técnico-instrumental. Nesse modelo pedagógico, a prática avaliativa é caracterizada pela aplicação de exames com vistas a medir se o aluno adquiriu o conhecimento transmitido, o que coincide justamente com o conceito da avaliação por objetivos desenvolvida por Tyler.

Em termos gerais, a concepção tyleriana da educação e avaliação insere-se no contexto de um movimento das primeiras décadas do século XX denominado "Teoria da Eficiência Social" (Social Efficiency Movement). Conforme explica Shepard (2000), esse movimento propõe a transferência de princípios modernos de controle científico para as escolas no intuito de otimizar o ensino. Uma das implicações dessa visão para a prática pedagógica caracteriza-se pelo ensino de habilidades em etapas: dada a impossibilidade de ensinar todo conhecimento de todas as áreas a todos os estudantes, 
passou-se a "educar de acordo com as capacidades de cada um", sendo a perda de tempo eliminada do processo.

Convém ressaltar que, embora as provas elaboradas tanto por Aida quanto por Sofia priorizem o ensino de conteúdos fixos, estáveis e de fácil mensuração, há um pequeno espaço para o tratamento da habilidade oral em tais avaliações. Nas provas de Aida, por exemplo, é possível notar que, num total de nove exercícios (em média), há um exercício para avaliar a comunicação oral. No Anexo 4, o exercício 7 trata de enunciados tipicamente utilizados para pedir permissão; no Anexo 5, a professora testa o conhecimento dos alunos na associação de perguntas e respostas utilizadas em diferentes situações discursivas, como mostra o exercício 2; finalmente, o Anexo 6 apresenta um exercício de tradução (vide exercício 2). Sofia, por sua vez, parece propor um exercício de comunicação oral um pouco mais contextualizado, oferecendo aos alunos mais informações quanto ao contexto de uso, tal como ocorre no exercício 3 (Figura 12) do Anexo 7:

3- Complete the dialogue. Choose from the expressions in the box:

\begin{tabular}{|c|c|c|}
\hline & drink? & Can I help you? \\
\hline A small packet & How much is that? & Anything else? \\
\hline
\end{tabular}

At the school cafeteria:

A-

B- Yes, a cheeseburger and a coke, please.

A-

B- A bar of chocolate, please.

B-

A- That's $£ 2.16$, please.

B- Here you are. Thank you.

Figura 12: exercício de comunicação oral, referente à situação discursiva "At the school cafeteria", extraído do Anexo 7.

Tendo explicitado o entendimento das participantes da pesquisa quanto a o que é avaliar e o que avaliar, ou seja, suas conceituações de avaliação e de conteúdo de avaliação, passamos agora a investigar as formas como avaliam seus alunos. 


\subsubsection{Problema 3: A prova escrita em seu pedestal}

As modalidades de avaliação, o como avaliar, podem ser tratadas sob diferentes perspectivas, assumindo-se diferentes escopos de análise. Interessa-nos, no entanto, pensar as modalidades da avaliação no âmbito da sala de aula, o que pressupõe investigar os rituais, as rotinas, as maneiras de fazer e de expressar os resultados da avaliação da aprendizagem (Vasconcellos, op.cit: 103).

Por influência da predominância do uso de testes objetivos ao longo do século XX (Vianna, 1995), os estudos em avaliação da aprendizagem nos mostram que a prova escrita constitui o instrumento mais utilizado no ambiente escolar dentre as mais variadas formas de registro avaliativo (Luckesi, op.cit.).

Amplamente difundidos na segunda metade do século XX, os testes objetivos eram caracterizados por dois tipos: os testes referenciados a normas ou avaliação normativa (norm-referenced testing) e os testes referenciados a critérios ou avaliação criterial (criteria-referenced testing). Segundo explica Vianna (1995), enquanto a avaliação normativa é originária dos testes objetivos utilizados logo nos primeiros anos do século XX e busca comparar percentualmente o desempenho dos sujeitos de um mesmo grupo, a avaliação criterial, sob influência dos posteriores estudos de Tyler (1949), verifica a aprendizagem do aluno em relação a objetivos previamente definidos, e não em relação a seus pares.

Ao discorrer acerca desses testes amplamente difundidos no século XX e ainda hoje bastante utilizados nos vários contextos educacionais, não podemos deixar de mencionar a crítica elaborada por Afonso (op.cit.). O sociólogo afirma que, embora o caráter estandardizado, seletivo e competitivo seja usualmente atribuído à avaliação normativa, ambos os tipos de testes podem apresentar essas características, funcionando como úteis indicadores de mercado. A crítica faz referência ao uso da avaliação criterial em nível macro por sistemas educacionais, como é o caso das avaliações em larga escala que vêm sendo utilizadas nos diferentes níveis escolares brasileiros. Se utilizada no âmbito da sala de aula, no entanto, a avaliação criterial, segundo Afonso (op.cit.), passa a ser confundida com a avaliação formativa, de caráter processual e dinâmico, com vistas a auxiliar a aprendizagem do aluno. 
Ao voltarmos nossos olhares para os contextos da pesquisa, percebemos que as formas de avaliação das professoras oscilam entre o caráter normativo e o caráter criterial. Sofia, por exemplo, faz uso de provas escritas com seus alunos de maneira sistemática conforme exige o colégio. A professora diz também considerar os trabalhos em grupo, avaliando os alunos individualmente pelo envolvimento que demonstram. No entanto, questionamos se a professora vê o trabalho em grupo com o olhar de um avaliador. Isso porque ela não costumava prover feedback imediato aos alunos enquanto estes desenvolviam seus trabalhos; tampouco produzia registros escritos para, posteriormente, poder fazer um julgamento do desempenho de cada um de seus aprendizes.

Nossa interpretação acerca dos registros escritos não pressupõe necessariamente a atribuição de notas ou "pontos extras", mas observações pertinentes que poderão ser úteis para o redirecionamento dos trabalhos. Luckesi (2005), por exemplo, vê os registros do professor, a construção dos instrumentos de coleta de dados, seu recolhimento, a correção e posterior devolução como importantes recursos para uma prática crítica e construtiva da avaliação no ambiente escolar.

Embora desenvolva projetos em grupo e simpatize com o Construtivismo, a prática avaliativa de Sofia não parece estar de acordo com essa proposta pedagógica. A avaliação cognitiva, mencionada pela própria professora, encontra-se, sim, articulada à abordagem construtivista, cujos pressupostos teóricos levariam a uma prática avaliativa centrada no aluno por meio de métodos introspectivos (Fidalgo, op.cit: 59). No entanto, os alunos de Sofia em momento algum participam de seus processos de avaliação. Há uma tentativa da parte da professora no sentido de dialogar com seus alunos, o que seria bastante desejável na pedagogia construtivista de que trata a professora, mas Sofia acaba por revelar um outro propósito, muito aquém da auto-avaliação enquanto mecanismo de crescimento individual e compartilhamento de decisões:

Sofia: no final do trabalho... até vou pedir na próxima aula que falem sobre o trabalho que eles fizeram agora... então me fala? Quem trabalhou? Quem não trabalhou?

((é uma espécie de auto-avaliação?))

Sofia: é... eles me falam quem trouxe quem não trouxe... e eles falam mesmo (risos)... eles falam tudo... aí eles me entregam o papel... cada 
grupo né... ( ) e aí dá o maior rolo... o bochicho que dá... ( ) mas eu tenho que fazer isso...

Em nossa leitura, a postura de Sofia parece incentivar a delação a serviço de sua posterior deliberação de julgamentos que beneficiará alguns alunos e prejudicará outros em suas notas finais.

Convém esclarecer ainda que a "avaliação cognitiva" de que trata Sofia não remete ao conceito de avaliação cognitiva de Vasconcellos (op.cit). Enquanto a primeira usa o termo "cognitivo" como processo introspectivo de identificação de saberes, sob influência da Psicologia cognitiva, o segundo destaca o "cognitivo" como sinônimo de conhecimento, no caso, conteúdo.

A prática de Aida também revela um excesso na aplicação de provas escritas, conforme as exigências da escola, o que acaba por orientar todo planejamento de aula. São constantes as atividades de revisão às vésperas dos dias de prova:

Aida: Para amanhã eu não vou cobrar todos esses... eu vou cobrar apenas "his" e "her" (...) para treinarmos vamos para a página trinta e seis fazer o exercício... vamos fazer o exercício oito (...) Agora rapidamente vocês vão completar a tabelinha... essa tabelinha não precisa estudar... por quê? porque não vai cair todos os pronomes.

Note-se, nesse trecho, o uso do verbo "treinar" bem como a justificativa da professora ao pontuar a não obrigatoriedade de se estudar um determinado conteúdo: não vai cair na prova. O ensino é, assim, orientado pela avaliação, quando, em nossa leitura, o contrário pareceria mais adequado.

A respeito da flexibilidade de ação e de seu poder decisório quanto à avaliação, Aida demonstra interesse em desenvolver os seus próprios instrumentos avaliativos:

((e aí a avaliação tem que ser baseada na apostila? Eles também sugerem a avaliação?))

Aida: Não... Até tem. Eles mandam...((refere-se à assessoria pedagógica do sistema Homo Sapiens))... até tem. Eles mandam por...né, a cada bimestre um:: um roteirozinho... que você pode ou não usar. Eu geralmente não uso o roteiro deles. Eu faço a prova em cima do conteúdo que eu dei, em cima dos exercícios da própria apostila... mas eu é que elaboro minha 
prova... eles até mandam como sugestão... né? Mas às vezes eu acho que fica meio fora da realidade dos alunos porque você acaba tendo que adequar o que você ensina à realidade daqueles alunos.

Nessa conjuntura de perda de autonomia ou do que Contreras (op.cit.) denomina de autonomia perdida ou ilusória, cabe ao professor aproveitar o seu momento em sala de aula para, de forma reflexiva, exercer o seu papel de educador, e não de mero executor de tarefas. Não deixa de ser uma tentativa da parte de Aida ao negar o uso dos instrumentos avaliativos pré-estabelecidos pelo sistema Homo Sapiens, embora o caráter reflexivo ressaltado por Contreras não tenha sido evidenciado em sua prática.

Assim é que a preferência de Aida e Sofia pela prova escrita corrobora a influência do viés psicológico no campo educacional predominante ao longo do século XX. Em nossa leitura, trata-se de um reflexo da supremacia dos testes objetivos nas primeiras décadas do século, os quais, sendo primeiramente utilizados para medir a eficiência das escolas e dos sistemas educacionais como um todo (Vianna, 1995), foram transferidos para o âmbito da sala de aula.

Uma outra forte razão da primazia da prova escrita está pautada na preocupação com a objetividade no processo de medida do desempenho. No início do século XX, uma avaliação formal escrita pressupunha um maior nível de neutralidade e objetividade do que qualquer outro instrumento avaliativo. Ao tratar da avaliação de língua estrangeira especificamente, Fidalgo (op.cit: 32) promove a crítica à ênfase ao aspecto objetivo na avaliação escolar ao longo dos tempos, atentando para a consolidação da legitimidade das provas escritas perante a comunidade escolar e a conseqüente dificuldade em desenvolver outras formas de avaliação menos formais ou burocráticas.

Em suma, a ênfase a instrumentos avaliativos que prezam a objetividade é decorrente da concepção de conhecimento do pensamento moderno, que legitima apenas o conhecimento científico, tido como real, verdadeiro, o qual, nas palavras de Morin (2005: 15), “dilui tudo que é subjetivo, afetivo, livre, criador".

Isso pode ser visto na própria insegurança e desespero das crianças quando passam a participar do ritual formal de avaliação - a prova. A esse respeito, vale a pena 
compartilhar o relato de Aida sobre a insegurança dos alunos de $5^{\text {a }}$ série durante as provas:

Aida: têm que se virar pra estudar a gente vai dando o apoio que pode, mas acaba ficando mesmo na mão deles porque normalmente, principalmente a quinta série... eles são MUITO dependentes... eles perguntam TUDO... eles fazem um negocinho e aí eles já vêm "tá certo?" então eles são muito dependentes... precisam muito de... da gente tá auto-afirmando ali né que "ai, tá bom, tá certo"... eles querem ter certeza do que estão fazendo... então na prova bimestral geralmente as notas caem MUITO porque eles ficam muito inseguros, você não tá lá, eles não podem perguntar... então é normal que na bimestral a nota dê uma caidinha...

Inserido no campo da psicologia, Smith (op.cit: 211) vê a negligência da criatividade no contexto educacional como fruto da própria dificuldade em medi-la objetivamente:

A considerable difficulty with perceiving the brain as an artist is that it does not facilitate control or 'accountability' in educational contexts (...) Creativeness is not easily quantified.

Dessa forma, as crianças desde cedo passam a temer a criação porque sabem que delas se esperam respostas corretas, objetivas, padronizadas (eles fazem um negocinho e aí eles já vêm "tá certo?" eles querem ter certeza do que estão fazendo). Suas curiosidades outrora valorizadas são agora proibidas e o exercício da dúvida, sugerido por Morin (op.cit.) é a elas negado. Esse quadro não condiz com a postura dialógica, aberta, curiosa, indagadora e não apassivada entre professores e alunos postulada por Freire (2004: 87), o qual vê a curiosidade como um dos saberes fundamentais à prática educativo-crítica.

Convém assinalar ainda o caráter autoritário da avaliação nas práticas de Aida e de Sofia. É interessante notar que em ambos os colégios, todas as provas são aplicadas por um professor de uma outra disciplina. Em determinado dia de observação de aula no colégio Teorema, a própria professora de inglês teve que aplicar a prova aos alunos, alertando-os, no entanto, o seguinte:

Aida: Pessoal... EMBORA... eu... estou aqui... FAÇAM de conta... que é UM OUTRO professor que está, OU SEJA eu NÃO VOU responder NADA porque AS OUTRAS turmas estão fazendo prova de inglês TAMBÉM, todo 
mundo está fazendo prova agora, e NINGUÉM... teve a minha ajuda. Portanto vocês também não terão. Tá bom? Então eu só desejo pra vocês boa sorte, NÃO adianta me perguntar nada porque eu NÃO vou responder, tá? ...

A justificativa apresentada por Aida diz respeito a uma questão de praticidade quanto aos horários das aulas. Já em conversa com a professora de Geografia do colégio Áureo (a qual aplicou a prova de inglês no $4^{\circ}$ bimestre), percebemos sua posição contrária à troca de professores, considerando-a improdutiva em termos administrativos, sem alusão ao aspecto pedagógico: "porque apesar da troca a gente tem que ficar indo nas salas pra ver se está tudo bem". Sofia não chegou a expressar sua opinião, mas o depoimento da professora de Geografia de certa forma corrobora nossa interpretação de que se trata de uma prática autoritária, com vistas a atingir um grau de objetividade e imparcialidade tal como os fiscais em dias de exames vestibulares, por exemplo.

Ao tratarmos do caráter autoritário nas práticas pedagógicas, a leitura de Foucault (2005) torna-se imprescindível. Na década de $70^{29}$, o pesquisador francês, ao tratar da “anatomia política" ou "mecânica do poder", assume a escola como instituição disciplinar para atender às exigências sociais. Nessa leitura, o exame constitui uma das principais técnicas disciplinares capazes de auxiliar eficazmente no processo de controle dos indivíduos, ou, conforme resume Ball (1997), um legitimador da docilidade e utilidade do sujeito.

Para Foucault (ibidem: 154), o exame constitui um ritual de poder, donde são combinadas "as técnicas da hierarquia que vigia e as da sanção que normaliza." Nesse sentido, o filósofo trata de dois instrumentos a serviço do exame: o olhar hierárquico e a sanção normalizadora.

O olhar hierárquico constitui a relação de fiscalização entre professor e alunos e até mesmo entre os alunos ${ }^{30}$, processo marcado por uma relação de poder em que o mais forte, o professor, vigia o mais fraco, o aluno. A partir disso, podemos inferir que a noção de olhar hierárquico em educação se dá no próprio ritual do exame em que o professor vigia e o aluno é vigiado:

\footnotetext{
${ }^{29}$ A primeira publicação de Vigiar e punir foi no ano de 1975.

${ }^{30}$ Segundo Perrenoud (1999), a fiscalização se realiza entre os próprios alunos uma vez que eles mesmos criam rotulações e seus próprios níveis de hierarquização no decorrer do ano letivo.
} 
((Aida referindo-se a alguns alunos)):

Aida: Eh Alexandre, vira pra frente, porque ele está com a prova e você também. Não importa que você já terminou.

((P referindo-se a outra aluna)):

Aida: Abaixa a sua prova, lindinha, que o colega lá atrás pode até copiar sua prova se ele quiser.

Ao retomarmos o olhar hierárquico de que trata Foucault (op.cit.), fazemos a leitura de que ele também está implícito na habitual unilateralidade nas tomadas de decisão do professor quanto aos conteúdos, formas e critérios de correção na avaliação de seus alunos e na falta de envolvimento dos alunos em seus processos avaliativos:

A1: Professora você já corrigiu as provas?

Aida: Sim:: eu corrigi as provas

A1: Por que que você não trouxe elas?

As: Ahhh ((desapontados))

Aida: Essas provas só serão entregues na reunião dos pais, que vai ser no próximo sábado.

Essa fala é reveladora de um viés autoritário na prática de Aida na medida em que não há incentivo para formas de feedback após um momento avaliativo formal. Durante a entrevista a professora nos esclarece que "pros alunos que os pais não vieram à reunião então aí a gente entrega a prova pro aluno mesmo..." Nota-se, com isso, que seus alunos não experimentam outros papéis que lhes permitiriam direcionar seus próprios processos de aprendizagens, tal como sugere Giroux (1997:71); pelo contrário, conforme aponta Apple (1989: 46), a interação entre professor e alunos restringe-se ao plano individual, na qual o primeiro gerencia todo o sistema numa relação de poder desigual.

Com relação à sanção normalizadora, Foucault (op.cit.) a define no contexto da dualidade "punição" versus "gratificação-sanção", donde um outro conjunto binário pode ser depreendido: a noção do bem, enquanto pólo positivo, e do mau, enquanto pólo negativo (ibidem: 151).

Esse mecanismo disciplinar esteve fortemente evidenciado no apogeu da proposta behaviorista de ensino, o que não nos permite afirmar seu desaparecimento nos contextos escolares atuais. O Behaviorismo ou Teoria Comportamental entende a 
aprendizagem como um processo passivo, mecânico e automático, sendo o conhecimento fruto de uma experiência num processo de estímulo-resposta constante, marcado ora pela punição, ora pela gratificação (Fidalgo, op.cit: 18). Esse mecanismo remete ao projeto de avaliação liberal, ilustrado na fala de Sofia:

Sofia: quando a Juliana a Daniela me falou a gente pode trazer/pode falar do papai Noel? ((no projeto sobre Global Warming)) eu falei CLARO que pode...ele veio de lá... mas olha como ela já FOI mais além... É ISSO que eu quero... o construtivismo É ISSO... então mesmo que ela tire zero numa prova eu nunca vou dar zero pra Daniela/por que? porque ela é talentosa... ela SABE TUDO... ela pode não tá indo/ela não foi bem nessa prova mas ela tem maturidade... como é que eu posso ignorar?... e aquele que/o Bruno... ele nunca faz nada... não fez o trabalho:: não veio:: eu não posso dar um dez mesmo que ele tenha tirado um dez nessa prova bimestral... isso é a avaliação construtivista... porque você um dia tá melhor outro dia você não tá:: você não tem dias que/eu pelo menos ... ah... faltou no outro dia:: não veio fazer a prova a avó morreu... como é que você pode lidar?... então se você lida/você tem que aceitar o aluno que você tem... tem problemas neurológicos:: psicológicos:: tem que tomar remédio e tal... então como que eu posso mudar o sentimento desse aluno? não dá...

Ao pressupor os resultados de seus alunos (vide trechos em negrito), numa espécie de pré-rotulação, a prática de Sofia não deixa de remontar à avaliação do modelo liberal conservador, do qual trata Luckesi (2004: 36):

(...) o professor traduz um modelo social, traduzido num modelo pedagógico, que reproduz a distribuição social das pessoas: os que são considerados 'bons', 'médios' e 'inferiores' no início de um processo de aprendizagem permanecerão nas mesmas posições, no seu final. Os 'bons' serão 'bons'; os 'médios' serão 'médios' e os 'inferiores' serão 'inferiores'.

O estudo da constituição da avaliação educacional permite-nos concluir que esta se definiu diante de uma base epistemológica racionalista, com forte influência dos fundamentos biológicos na primeira metade do século XX. Conseqüentemente, tal investigação direcionou nossos olhares para três categorias de análise, justamente por considera-las predominantes e incisivas ao longo das décadas, ressoando nos três contextos escolares investigados. Da análise de tais categorias, identificamos a emergência de três problemas da avaliação da aprendizagem no paradigma da 
modernidade: referimo-nos ao conceito de avaliação como sinônimo de mensuração; a ênfase à avaliação de conteúdos objetivos e estáveis; e a primazia da prova escrita dentre as várias modalidades de avaliação.

\subsection{Um novo paradigma de avaliação?}

Diferentemente de Aida e Sofia, que parecem priorizar o caráter mensurável da avaliação, a concepção de avaliação de Beatriz é construída com referência aos usos e propósitos da avaliação. Isso porque a professora sempre conceituava avaliação por meio da explanação dos motivos que a levam a avaliar seus alunos:

Beatriz: porque o aluno precisa ta sempre estudando e ele tem que refletir... avaliar... passar o conhecimento pra uma nova situação (...) pra que eles possam estar transferindo a situação...

Em uma das aulas, a professora propôs uma avaliação aos alunos. A forma como aborda a atividade com seus alunos é reveladora de seu conceito de avaliação:

Beatriz: Eu quero saber o que cada um aprendeu... não precisa fazer a capa. Eu vou colocar as frases em inglês e a tradução mas vocês coloquem as respostas em inglês. Eu quero saber se vocês conseguiram de tudo o que eu falei entender... podem consultar as anotações de vocês no caderno (...) Pessoal isso é muito importante... isso é uma atividade para eu saber se você entendeu ou se não entendeu.

Do trecho acima podemos inferir que o conceito de avaliação de Beatriz está pautado na preocupação em acompanhar o desenvolvimento do aluno com o intuito de garantir a aprendizagem. Embora adote técnicas tipicamente tradicionais nas aulas de inglês, como o uso da tradução e a ênfase à estrutura gramatical, sua narrativa revela sua representação de avaliação num sentido macro como exercício de construção do conhecimento por meio do diálogo.

Os propósitos da avaliação educacional, no caso o questionamento quanto ao por que avaliar, somente foram considerados ao final do século $\mathrm{XX}$ devido às influências da Sociologia da educação. A abordagem crítico-sociológica da avaliação emergente ao final do século XX apresenta grandes contribuições para pesquisadores da área na medida em que denuncia a falta de questionamentos mais amplos e profundos quanto às 
possíveis razões para determinadas ações pedagógicas em detrimento da predominância de pesquisas reduzidas ao entendimento do processo em si (Broadfoot, op.cit.), possibilitando-nos a compreensão das contradições e dos conflitos de interesses nas relações sociais e conseqüentemente à exploração das 'brechas que abrem caminho para as rupturas e mudanças' (Franco, 1983).

Nesse sentido, a dimensão tecnológica da avaliação advinda das influências do ensino positivista de boa parte do século XX cede espaço a novas concepções da avaliação, cujas preocupações como a democratização do ensino demonstram uma ótica mais sociológica, comprometida com o desvelar das práticas de sala de aula, passando a considerar a escola um espaço de possibilidades (Sousa, 1995).

Para Ludke (2002), essa mudança de paradigmas nos estudos em avaliação educacional advém em grande parte da consolidação da pesquisa qualitativa e de estudos etnográficos. A autora expõe que, anteriormente à década de 70 , quando da predominância da pesquisa positivista de caráter quantitativo, a avaliação caracteriza-se essencialmente por sua preocupação com a mensuração de dados, baseada em juízos de fato. Nos anos 70, porém, alguns pesquisadores iniciam uma reflexão a respeito das limitações da pesquisa quantitativa na aplicação de seus princípios em educação. Tratase do surgimento de uma nova corrente, a qual proporá a inclusão de outros critérios avaliativos, pautados não somente em juízos de fato, mas também em juízos de valor.

Segundo Vianna (1995), vários teóricos em âmbito internacional iniciam uma série de debates na década de 70 , dado o reconhecimento das limitações nos estudos essencialmente quantitativos em avaliação educacional até então produzidos, possibilitando a construção de novas conceituações e métodos avaliativos.

Dentre essas novas conceituações, destacamos a definição de avaliação de Scriven (1967, apud Vianna, ibidem), o qual passa a entendê-la como a determinação de um valor ou mérito do objeto avaliado, conceituação esta que contribuirá para a aceitação da natureza subjetiva da avaliação. 
Atribui-se igualmente a Scriven ${ }^{31}$ o conceito de avaliação formativa, muito difundido no discurso educacional brasileiro. Segundo Bonniol e Vial (op.cit.: 288), enquanto a avaliação somativa é pontual e monorreferenciada, a avaliação formativa:

(...) tenta dar sentido ao objeto avaliado e inseri-lo em uma dinâmica de mudança; portanto, ela se insere no tempo, acompanha os processos e envolve a multirreferencialidade (os diferentes atores da situação são fontes de avaliação úteis e sujeitos de avaliação necessários).

O cuidado de Beatriz em acompanhar os alunos mesmo não havendo exigências burocráticas para tal prática corrobora nossa leitura da postura formativa adotada em sua prática pedagógica. A esse respeito, é Vasconcellos (op.cit.) quem trata da avaliação formativa como uma postura e não como um tipo de avaliação. Assim é que um professor que se utiliza apenas de provas escritas, por exemplo, poderá praticar uma avaliação formativa, dependendo de como ele vê a avaliação.

Acrescente-se, ainda, o fato de Beatriz conhecer todos os alunos de suas turmas, chamando-os por seus nomes e demonstrando acompanhar o desenvolvimento de cada um deles:

Beatriz: eu dou nota de caderno também... eu passo dando visto... eu tenho uma página pra cada sala...aqui por exemplo na $6^{\mathrm{a}} \mathrm{A}$ nesse $4^{\circ}$ bimestre aqui nós já estamos na quarta atividade... o Ademar ó...((Beatriz mostra lista para mim)) não fez nenhuma apesar de estar na classe... o Edson fez duas... deixou duas sem fazer... isso é o visto do caderno... ao passo que você vê que tem outros que fazem tudo ó ... então bimestralmente eu vou marcando e depois eu faço uma média... média de caderno... no outro bimestre eu já fechei ( ) aqui ó... terceiro bimestre:: no caderno:: o Ademar chegou a fazer metade das atividades... então quem tem (menos) uma até metade fica com $\mathbf{S}$ de caderno... que é "satisfatório"... quem tem menos da metade como é o caso da Carla... fica com NS... eu só vou dar nota P se ele tiver completo... isso pro caderno... faltou uma só ele fica com S... isso é bimestral... olha o segundo bimestre deles... ó o Ademar aqui de novo... tava com NS de caderno... aqui é um termômetro... o Edson não estava aqui ainda... ele veio no segundo semestre... você vê/um:: dois:: três::

31 Embora situado no bojo das discussões acerca da avaliação de programas, Scriven acabou por influenciar os estudos em avaliação da aprendizagem na medida em que estes 'emprestaram' a conceituação de avaliação formativa. 
quatro:: olha quantos Ps... bastante né? então a parte do caderno é uma atividade que a MAIORIA tem em dia... ${ }^{32}$

O comprometimento de Beatriz em acompanhar o cumprimento das tarefas de cada um de seus alunos para redirecionamento de sua prática parece condizente com a definição de avaliação formativa apresentada por Scaramucci (1998/1999: 118):

Em substituição à avaliação de produto, através de testes, hoje fala-se em avaliação de processo, contínua, não apenas somativa mas também formativa; processo dinâmico, interativo e negociável, que extrapola o uso de testes e provas; avaliação individualizada, que leve em conta aspectos afetivos.

A exemplo de Scaramucci em âmbito acadêmico, muitos pesquisadores brasileiros direcionam seus olhares a partir da década de 80 para novas concepções da avaliação, menos atreladas à mensuração, classificação e autoritarismo, aspectos estes, segundo Luckesi (2003, 2005), arraigados na educação brasileira desde a pedagogia jesuítica. Inaugura-se, portanto, um período frutífero permeado por um novo paradigma de avaliação, adepto da perspectiva crítica (Chaves, 2003), embasado por práticas anticlassificatórias, anti-autoritárias e anti-excludentes e compromissadas com um denominador comum, a democratização do ensino. Segundo Fidalgo (op.cit.:22), tratase de uma ruptura da influência da filosofia positivista no tratamento da avaliação da aprendizagem. Como conseqüência, tem-se a difusão de novos conceitos de avaliação, acompanhados da divulgação de outras formas de avaliar que não apenas a prova.

A esse respeito, é interessante ressaltar o uso da auto-avaliação (vide Anexo 9), por Beatriz, sobre a qual convém transcrever o trecho todo:

Beatriz: porque como a gente não tem o livro e nem caderno eu não tenho como tá avaliando... então eu tenho o diário deles aqui mas eu costumo marcar as atividades aqui... trabalho em grupo:: trabalho em dupla:: as frases:: e vou pondo aqui... exercício:: trabalho individual:: não é? nota de caderno:: auto-avaliação:: que é uma atividade que eu desenvolvo com eles que tem um ROTEIRO de perguntas:: que eles vão se dando uma pontuação...

((isso todo bimestre?))

Beatriz: todo bimestre... eu chamo de cidadania...

32 Os conceitos utilizados por Beatriz são: P (Plenamente satisfatório), S (Satisfatório) e NS (não satisfatório). 
((o que que eles acham disso?))

Beatriz: tem alguns que falam... outra vez professora? que nós combinamos no início do ano que essa auto-avaliação que é CIDADANIA... que são os seus direitos e os seus DEVERES principalmente é feito por bimestre... então de manhã são quatro bimestres e no noturno são só dois... que é semestral... as perguntas são essas ó... freqüências às aulas... utiliza somente o limite permitido de cinco por cento?... então se ele utiliza ele vai se dar nota CINCO... se ele passa do limite das faltas... precisa compensação de ausência ele vai se dar nota dois...e se aquele aluno que falta muito além da compensação de ausência... ele tá bem estourado em falta... ele vai se dar nota zero porque ele nunca tá presente... aí na pergunta dois... o caderno contém as anotações BÁSICAS... resumos:: tabelas:: exemplos:: textos:: diálogos:: e eu falo pra eles... toda vez que eu vou fechar a MÉDIA do bimestre é pelo CADERNO que eu faço a média... se eu to na dúvida se o aluno merece nota $\mathrm{S}$ ou nota $\mathrm{P}$ na média do semestre... eu olho o caderno porque é o nosso único instrumento mesmo do dia-a-dia... porque não tem livro... ((Beatriz continua pontuando cada uma das perguntas do roteiro)).

A forma como a professora conduz a auto-avaliação demonstra seu conhecimento a respeito desse instrumento, o qual deve ser direcionado e baseado nas atividades do cotidiano escolar, a fim de se evitar julgamentos impressionistas (Luckesi, 2005).

Mais uma vez, instigamos a professora a nos mostrar seus propósitos com relação ao uso de todos esses instrumentos avaliativos (as atividades individuais e em grupos, o uso do caderno, a auto-avaliação). Sua resposta parece reveladora de uma obrigação moral, de seu compromisso com seus alunos:

((quer dizer... isso tudo o governo não te obriga a fazer... não é...)) Beatriz: não... eu to fazendo isso daqui porque eu quero ver se CRIA uma consciência pra melhorar enquanto estudante... pra eles CUMPRIREM os deveres deles... porque se você faz uma auto-avaliação e não dá um roteiro... eles vão escrever SÓ um monte de bobagens... por exemplo aqui... comentários... por que que você merece ficar com essa nota?... tem uns que escrevem assim... porque eu sou maravilhoso:: ((risos))

Em nossa análise, a postura de Beatriz remete ao conceito de profissionalidade docente (Contreras, op. cit.) referente ao modo de ser do professor, pautado não apenas no desenvolvimento dos saberes necessários ao exercício da profissão, mas essencialmente em seus valores, suas representações. Trata-se do 'específico de ser' professor, de sua atuação prática inserida numa dimensão política. 
Ao caracterizar a profissionalidade docente, ou seja, o modo específico de ser professor, Gimeno Sacristán (1998, apud Cunha, 1999:145), por sua vez, dá relevância ao aspecto moral na medida em que "a ética que resgata a utopia e a ideologia que se manifestam na sua intencionalidade" acabam por estruturar a profissão docente.

Ainda sobre a auto-avaliação proposta por Beatriz, é interessante evidenciar a forma como a professora provê feedback aos alunos, correlacionando os julgamentos que eles mesmos constroem, as suas próprias percepções e o desenvolvimento deles no decorrer do ano letivo:

((mas a maioria se dá a nota que você considera justa?))

Beatriz: a maioria dá... eu falo eu acho que você ainda não está merecendo esta nota... porque nos itens tais:: tais:: tais:: você ainda não está tão bem... você ainda não tá tudo isso... eu escrevo assim com jeito pra não magoar ninguém né? deixa eu pegar algumas de uma outra série... da quinta série aqui... tem a auto-avaliação do quarto bimestre ainda... deixa eu pegar aqui... ó... aqui um exemplo.... eu mereço esta nota porque participo das aulas:: faço de tudo pra deixar o meu caderno organizado:: e adoro MUITO as aulas de inglês...

((e é mesmo?))

Beatriz: é... geralmente é... aí eu coloco uma observação ó... nesse caso eu pus assim... parabéns... você é um ótimo estudante de inglês... continue assim...

((e aí você entrega pra eles?))

Beatriz: isso ó... esse aqui/o Ismael... ele estudava nessa sexta A da manhã e passou pra noite... melhorei muito desde eu ter de sair da parte da manhã... aí eu pus... concordo com você... mas você pode melhorar ainda mais... ESTUDE e verá... parabéns... eu já disse pra ele que realmente a mudança foi MUITO grande... ele era terrível de manhã... do tipo assim daquele que senta perto da porta... o Cleiderman... não pára quieto... mais ou menos daquele estilo... não parava no lugar:: só conversando:: não fazia:: não tinha caderno

Embora a professora demonstre avaliar seus alunos no intuito de promover $o$ aprendizado, convém acrescentar o fato de que, ainda assim, a avaliação em alguns momentos caracteriza-se como mecanismo para o controle da indisciplina. Isso porque, apesar dos alunos estarem cientes da não reprovação no decorrer dos ciclos, eles mudam seus comportamentos nos momentos de avaliação formal, ainda praticados por Beatriz, na medida em que a professora os alerta para uma possível reprovação ao final do ciclo: 
((eles ficaram mais quietos... foi por causa da avaliação?))

Beatriz: foi por causa da avaliação... porque tem professor que pega pesado na avaliação.

((então, mas aí o aluno sabe que não reprova...))

Beatriz: sabe...

((e mesmo assim ele leva a sério...))

Beatriz: mas é que nós falamos pra eles... EU pelo menos falo bastante... se você não fizer as atividades desta série como que você vai acompanhar na série seguinte? Vai ficar um pouco mais difícil:: vai ter mais conteúdo:: outras coisas novas:: tem coisa que você vai ver lá na frente que vai depender disso daqui que eu to falando... e se você não chega na oitava série e não acompanhar você vai ficar tirando diploma de oitava série... vai ficar lá reprovando... reprovando... reprovando.. que horas que você vai acabar o seu curso?

Com base nos trechos da entrevista e das aulas de Beatriz, os quais evidenciam uma postura formativa e compromissada da professora, julgamos possível tecer a análise de seu entendimento acerca da avaliação educacional em concordância com o novo paradigma da avaliação ao final do século XX. Isso não significa que a conceituação de avaliação da professora da EMEF deixou de ressoar as influências da base epistemológica racionalista, postulada pelo pensamento moderno, uma vez que esta encontra-se arraigada nas práticas sociais; trata-se, no entanto, de realçar as diferentes visões de mundo das participantes da pesquisa bem como seus entendimentos acerca de suas práticas pedagógicas, cada qual inserida num determinado contexto.

\subsection{Avaliação e os modelos de ensino de línguas: outras descontinuidades}

Por estarmos situados no campo das pesquisas sobre língua estrangeira, entendemos a necessidade de articular as teorias em avaliação educacional com as teorias de ensino de línguas. Embora possa parecer exercício óbvio, tal articulação nem sempre é possível diante do pouco afinco com que a avaliação da aprendizagem vem sendo tratada no âmbito do ensino de línguas estrangeiras (Almeida Filho, 1998; Rolim, 1998; Scaramucci, op.cit.). A esse respeito, discorre Almeida Filho (ibidem: 67):

Embora de alta importância, a questão da avaliação não tem merecido o mesmo volume de iniciativas de pesquisa que as outras fases da operação global do ensino de línguas, constatamos que se trata da menos discutida questão nas pesquisas nacionais. 
Este trabalho não pretende esmiuçar as razões pelas quais a avaliação constitui o aspecto menos investigado (e paradoxalmente um dos mais complexos) nas pesquisas sobre língua estrangeira, mas julga pertinente expor a problematização. De qualquer forma, as três realidades observadas não deixam de ilustrar a relevância da questão na medida em que diferentes modelos de ensino de língua abarcam as mesmas conceituações de avaliação, assim como, em outros instantes, diferentes usos da avaliação parecem servir a concepções similares de língua, havendo espaço para afirmarmos outras descontinuidades nos contextos investigados quando da relação entre ensino de língua e avaliação.

Considerando o conceito de língua de Aida enquanto sistema lingüístico fechado, seus instrumentos avaliativos evidenciam coerência com relação ao seu conceito de língua e à abordagem estruturalista adotada pela professora . Essa análise é depreendida de suas provas, dos trechos anteriormente transcritos e também do que se segue:

\begin{abstract}
Aida: se eu acabei de dar a matéria e der uma contínua ali no final da aula...o aproveitamento dele também vai ser bom... se eu deixo vai... duas semanas e dou a matéria... aí já é outra coisa... sem avisar né? porque eu posso fazer isso tudo sem avisar... e justamente pra ver se ele memorizou ou não memorizou... então assim dá certo porque se você faz... se você souber mesclar bem você vai conseguir identificar se teu aluno conseguindo memorizar ou não, se alguém tá ajudando ou não, se foi uma questão que tava ali na cabeça no momento...
\end{abstract}

Assim, a coerência entre o ato de ensinar e o ato de avaliar se dá diante da confirmação de seu entendimento de língua como código lingüístico, com ênfase ao seu aspecto estrutural, e sua preocupação em verificar a memorização de conteúdos (e justamente pra ver se ele memorizou ou não memorizou...)

Beatriz, por sua vez, também parece entender a língua como código lingüístico, priorizando o ensino fragmentado e descontextualizado da gramática e de vocabulário, conforme ressaltamos no capítulo I. No entanto, sua concepção de avaliação não nos parece a mesma de Aida, uma vez que a professora transparece uma postura avaliativa formativa por meio de atividades e provas que "valem nota", sim, mas com outros propósitos que vão além de mera medida de desempenho (eu quero saber se vocês 
conseguiram entender... podem consultar as anotações de vocês no caderno (...) Pessoal isso é muito importante... isso é uma atividade para eu saber se você entendeu ou se não entendeu). Trata-se, em nossa interpretação, de um esboço de avaliação articulado ao viés sociológico, que curiosamente vai além do entendimento de linguagem da professora e da própria abordagem estruturalista de que se utiliza.

Além de desenvolver atividades avaliativas, vimos que Beatriz faz uso da autoavaliação. Aliás, a auto-avaliação constitui um instrumento avaliativo tipicamente inserido nas teorias cognitivistas de caráter humanista (Fidalgo, op.cit: 35), sendo amplamente divulgada por abordagens como a construtivista - justamente a abordagem mais referida por Sofia. Esta, contudo, não faz uso da auto-avaliação com seus alunos, priorizando a prova escrita como pudemos perceber.

Nesse espectro, é curioso notar o fato de Beatriz não se mostrar adepta de uma abordagem humanista-moderna, uma acepção de Saviani (1991) conforme exposto no Capítulo I, mas utilizar-se da auto-avaliação como forma de tentar propiciar a centralidade de seus alunos no processo educativo, ou, numa leitura menos pretensiosa, como forma de simplesmente dialogar com seus alunos sobre seus desempenhos.

Outra curiosidade constitui ainda o fato de Sofia, simpatizante do Construtivismo, desenvolver os projetos em grupo, mas não considerá-los com a mesma relevância que considera os resultados das provas, o que constitui uma inconstância entre a concepção construtivista de educação e o conceito de avaliação de Sofia. A professora nos disse que leva em conta os projetos em grupo, o que aliás pudemos testemunhar; no entanto, suas descontinuidades dizem respeito aos propósitos de sua avaliação de projetos:

Sofia: na média entre tudo... quem traz o trabalho:: quem fez:: quem procurou:: quem trouxe:: eu não tenho que dar nota pra todos do grupo... ISSO É O PONTO PRIMORDIAL na minha avaliação em relação aos projetos...

No que diz respeito à avaliação dos projetos, a professora beneficia com um ponto extra aqueles que trazem as figuras e os textos. Essa forma de avaliação não parece, portanto, condizente com o trabalho em grupos tipicamente desejável na perspectiva 
construtivista de ensino. Há, em nossa leitura, uma postura autoritária e punitiva de Sofia em alguns momentos, conforme ilustram algumas das anotações de campo:

((Sofia referindo-se a um aluno de um dos grupos no projeto sobre animais extintos)):

Sofia: No grupo só você não trouxe???

A: É.

Sofia: Eu vou ter que marcar isso.

No projeto "Global Warming", a professora, possivelmente tomada pelo cansaço ao final do ano, se irrita com um dos alunos e revela os seus objetivos com relação aos projetos:

Sofia: Eu não estou nervosa.. eu estou brava. Sabe pra que que eu to fazendo isso? Pra dar nota de graça pra vocês.

Em termos gerais, entendemos que as descontinuidades nos conceitos de língua, modelos de ensino de línguas e avaliação identificadas ao longo da pesquisa parecem oscilar entre a concepção restrita de conhecimento do pensamento moderno, calcada na ênfase do real e da verdade sobre as coisas e uma concepção de conhecimento da pósmodernidade, tipicamente postulado por teóricos pós-estruturalistas, os quais entendem o conhecimento como construção social em que a heterogeneidade de saberes, práticas e experiências passa a ser considerada em detrimento da razão instituída e restauradora de identidades fixas (“o ${ }^{33}$ social, o político, o sujeito, a arte etc", Favaretto, op.cit.: 30). Assim conceitua Favaretto (ibidem: 33) a noção de conhecimento sob a ótica do pensamento pós-moderno:

O conhecimento é descoberta de relações entre signos; o conhecimento tem as propriedades do acontecimento, cujas regras e categorias não são dadas, mas se estabelecem na produção das relações.

O modelo estruturalista de ensino adotado por Aida e Beatriz, por exemplo, está pautado na idéia de unidade e fixidez de sentidos (Nascimento, 1995), na qual a interpretação do aluno-sujeito fixa-se diante do que lhe é posto, não havendo espaço para múltiplas significações. A mesma ênfase à univocidade de sentido é evidenciada

\footnotetext{
${ }^{33}$ Grifos originais do autor
} 
nas provas de Sofia, mas não em suas narrativas acerca das abordagens de ensino, as quais se mostram favoráveis a uma concepção de língua como construção social.

Ressalva-se, no entanto, que, embora o entendimento de Sofia sobre a língua pareça avançar diante das limitações da abordagem estruturalista, a professora não chega a priorizar as negociações de sentidos entre os sujeitos intérpretes de que trata a concepção pós-estruturalista.

Para Bakhtin (2004) ${ }^{34}$, importante teórico pós-estruturalista, o processo de significação vai além da simples relação entre significante-significado postulada pelo Estruturalismo, dada a possibilidade de negociação de sentidos pelo sujeito-intérprete, este situado sócio-ideologicamente na história. Ao propor um tratamento dialógico ao signo lingüístico, Bakhtin nega a dicotomia saussuriana, entendendo que todo processo de significação é contextualizado, dialógico e ideológico (Menezes de Souza, 2004: 128).

Assim, parece-nos que Sofia entende a importância das relações sociais no processo de ensino-aprendizagem ao mostrar-se adepta ao Construtivismo, mas não prioriza a negociação de sentidos entre os sujeitos provavelmente pelo fato da teoria piagetiana não ter contemplado tais aspectos, enfatizando o contexto centrado na relação sujeitoobjeto, e não sujeitos-sujeitos (Mizukami, op.cit.; Tosi, op.cit.)

É possível que essa negociação de sentidos alavancada pelo caráter dialógico do signo bakhtiniano ressoe em algumas das atividades avaliativas propostas por Beatriz, já que, embora inserida no modelo de ensino estruturalista, sua concepção de avaliação abarca parte das contribuições da abordagem sociológica aos estudos educacionais.

Diante desse quadro em que concepções de língua, modelos de ensino e avaliação transitam sob diferentes formas e tomam diferentes rumos, percebemos uma trama de práticas pedagógicas distintas e descontínuas e, em alguns momentos, semelhantes e regulares. Convém lembrar que esse vaivém de regularidades e descontinuidades não parece ocorrer apenas quando da comparação entre as realidades observadas, mas sobretudo em cada uma das práticas investigadas em seu contexto específico,

\footnotetext{
${ }^{34}$ Primeira publicação em 1929.
} 
ressalvando-se, assim, nossa não pretensão de traçar comparações entre fenômenos, aspecto aliás voltado às pesquisas de natureza positivista.

Das descontinuidades na relação entre os modelos de ensino adotados e as práticas avaliativas especificamente, podemos resumir que estas não condizem com as concepções de língua em alguns dos contextos, como é o caso de Beatriz e Sofia. Quanto às regularidades, há que se considerar uma certa linearidade na prática pedagógica de Aida tomada em seu contexto específico.

Isso nos permite concluir que enquanto novas concepções de língua são desenvolvidas ao longo dos tempos, mostrando-se condizentes com os novos paradigmas que vão se construindo, as concepções de avaliação parecem não avançar de forma a acompanhar tais mudanças epistemológicas, fazendo-se prevalecer ainda o projeto liberal de avaliação que perpassou todo o século XX.

Compartilhamos das preocupações de Vasconcellos (op.cit.), no Brasil, e de Álvarez Méndez (op.cit.) em âmbito internacional, quanto à possível incompreensão do que significa avaliar o aluno diante de uma abordagem crítico-sociológica. Isso porque apesar do surgimento de novas formas de avaliação alternativas à avaliação 'tradicional' a partir dos anos 80, é duvidoso afirmarmos uma ruptura entre o velho paradigma da avaliação de caráter liberal-positivista, e um novo paradigma da avaliação ao final do século, cujo discurso de denúncia pautou-se em práticas menos autoritárias e mais inclusivas. A concepção de Beatriz certamente mostra-se mais adequada em determinados aspectos se comparada ao velho paradigma, mas receamos afirmar que se trata de uma ruptura epistemológica.

Nossas inquietações são ainda mais agravadas se considerarmos o que Afonso (op.cit.) denomina "o novo viés positivista da avaliação", caracterizado pela ênfase ao produto, aos instrumentos mensuráveis, à seleção e à competitividade com vistas a atender as exigências do mercado e traduzido nas políticas educacionais atuais em diversos países. 
Isso porque tais políticas vêm priorizando a avaliação dentre seus temas mais recorrentes, sobretudo a avaliação externa em larga escala ${ }^{35}$, pois esta tem sido tomada como principal mecanismo de controle do Estado (Sousa e Oliveira, 2003) e de verificação dos níveis de excelência e eficiência, assumindo a função de promover qualidade por meio da competição entre instituições, caracterizando, assim, o que Catani e Oliveira (op.cit.) denominam "cultura do aprimoramento". Esse quadro revela, portanto, uma política meritocrática engendrada pelo financiamento diferenciado vinculado à avaliação de tais instituições e a conseqüente perda ou ganho de "clientes" das instituições de ensino, a depender de suas posições nos rankings divulgados publicamente $^{36}$.

Corroborando as idéias de Catani e Oliveira (op.cit.), Gentilli (op.cit.) explica que, em termos práticos, da obsessão pela medição da qualidade, passa-se a divulgar rankings das instituições de ensino, os quais funcionam como uma espécie de termômetro que possibilita a sociedade escolher as instituições com melhores pontuações, obrigando que os fracassados ao final da lista tomem as devidas providências para modificarem seus quadros. Configura-se, dessa forma, um sistema competitivo com incentivos e punições (Catani e Oliveira, op.cit.), tanto em termos concretos como o oferecimento ou corte de verbas da parte do Estado a depender dos resultados das instituições, quanto em termos simbólicos, referentes à sanção da própria sociedade.

$\mathrm{Na}$ medida em que hoje duas políticas contraditórias caminham juntas no espaço escolar, a saber, a política neoliberal das exigências e a política das necessidades (Dalben, 1991), pensar os possíveis rumos da avaliação da aprendizagem de línguas torna-se um desafio; desafio este que adquire maior proporção se considerarmos as recentes transformações na base epistemológica do conhecimento sinalizadas pelas teorias de letramentos, de que trataremos no capítulo subseqüente.

\footnotetext{
${ }^{35}$ Entende-se por avaliação em larga escala os instrumentos avaliativos externos ao ambiente escolar e aplicados em âmbitos nacional e internacional. No Brasil, constituem exemplos de avaliações externas a Prova Brasil (desde 2005), o ENEM (Exame Nacional do Ensino Médio, desde 1998) e o ENADE (Exame Nacional de Desempenho dos Estudantes, implantando em 2005 em substituição ao extinto ENC - Exame Nacional de Cursos, criado em 1995).

${ }^{36}$ A exemplo das publicações dos resultados do ENEM e das avaliações do Ensino Superior.
} 


\section{As novas teorias de letramento}

(...) new communications media are reshaping the way we use language. When technologies of meaning are changing so rapidly, there cannot be one set of standards or skills that constitutes the ends of literacy learning, however taught. COPE E KALANTZIS (2000)

\subsection{Uma nova base epistemológica de educação}

De acordo com Lankshear e Knobel (2003), diversos são os fatores que impulsionaram o desenvolvimento das teorias de letramento (literacy) ao final do século XX, dentre os quais destacamos a pedagogia crítica de Paulo Freire; a necessidade de reforma curricular em face do crescente analfabetismo nos Estados Unidos dos anos 60 e ainda a emergência de estudos socioculturais decorrentes da influência do viés sociológico sobre o campo educacional ao final do século XX.

Conforme resume Soares (2004: 91), muito além da aquisição de uma 'tecnologia da escrita' que nos possibilite a leitura e escrita tal como se propõe o processo de alfabetização, o conceito de letramento postulado a partir dos anos 70 refere-se a um exercício efetivo e competente de uma determinada tecnologia da escrita, o que implica o conhecimento de várias habilidades. A autora ainda afirma que a aprendizagem da língua escrita não se reduz a uma questão técnica, uma vez que se encontra situada politica e ideologicamente nos diferentes espaços sociais e culturais (Soares, 2005).

É importante esclarecer que o termo literacy, em inglês, abarca também o significado de alfabetização, em português ${ }^{37}$. No entanto, após os anos 70 os estudos sobre literacy nos Estados Unidos, primeiramente associados à educação não formal de adultos não

\footnotetext{
${ }^{37} \mathrm{O}$ significado denotativo apresentado em dicionários bilíngües, por exemplo, donde o termo derivado "illiterate" passa a ter como tradução para o português o termo "analfabeto".
} 
escolarizados, passaram cada vez mais a assumir relevância nas discussões do campo educacional, abrangendo, mais tarde, a educação formal. Em termos gerais, esses estudos produziram uma nova concepção acerca dos processos de aprendizagem da leitura e escrita, para além do domínio de um código lingüístico (Soares, 2004), concepção essa difundida no Brasil pelo uso do termo letramento.

Hoje, pesquisadores em âmbito internacional como Lankshear e Knobel (op.cit.) têm utilizado o termo new literacy studies, ou novos estudos de letramento, de forma a revisitar o conceito de literacy dos anos 70 diante das transformações da sociedade contemporânea. Convém ressaltar que outros ainda utilizam o termo literacies, em sua forma plural, ou, tal como Cope e Kalantzis (2000), Multiliteracies, para designar a multiplicidade de usos da linguagem e de estratégias e habilidades envolvidas neste novo processo de produção de sentidos.

A recente difusão desse conceito mais amplo de letramento como o desenvolvimento de habilidades para lidar com um determinado sistema, saber sua linguagem e ser capaz de produzir sentidos provém de mudanças significativas nunca dantes vivenciadas ou sequer vislumbradas ocorridas no campo da informação eletrônica e no campo das tecnologias das comunicações. $\mathrm{Na}$ medida em que tais tecnologias evidenciam uma valorização dos usos sociais da linguagem, teóricos (Lankshear e Knobel, op.cit.; Cope e Kalantzis, op.cit.; Gee, op.cit.) ressaltam importantes transformações na base epistemológica de educação, cujo conceito de 'leitura' tradicionalmente concebido em termos psicológicos, cede espaço ao conceito de letramentos, este último embasado em termos sociológicos.

Nesse sentido, de um modelo epistemológico convencional do tratamento do texto, passamos a novas formas pós-tipográficas de práticas textuais, nas quais o texto deixa de apresentar o formato linear outrora predominante (Lankshear e Knobel, op.cit.: 17). Em lugar do texto linear, o texto na era digital apresenta-se amalgamado por meio da aproximação e justaposição de diferentes modos de comunicação, dentre os quais textos $^{38}$, imagens, sons, gráficos, emoticons, hyperlinks (Lankshear e Knobel, op.cit.). Trata-se, pois, do conceito de multimodalidade dos meios de comunicação (Monte

\footnotetext{
${ }^{38}$ No sentido convencional, como código de escrita ou o conjunto de parágrafos organizados linearmente.
} 
Mór, 2006) cuja leitura e interpretação não mais poderão ser desenvolvidas no paradigma tradicional do ensino de línguas

Cope e Kalantzis (op.cit.), por exemplo, denominam essa nova configuração textual 'amalgamada' de Multiletramentos, cuja prática educacional prioriza modos de representação muito mais amplos do que a língua per se. Nesse sentido, enquanto a pedagogia tradicional de letramento permanece centrada no ensino da língua como um sistema estável e homogêneo baseado em regras pré-estabelecidas, uma pedagogia de multiletramentos entende a linguagem e outros modos de significação como recursos representacionais dinâmicos, sendo constantemente recriados por seus usuários:

No longer do the old pedagogies of a formal, standard written national language have the utility they once possessed. In contrast, the Multiliteracies argument suggests the necessity of an open-ended and flexible functional grammar which assists language learners to describe language differences (...) and the multimodal channels of meaning now so important to communication.

(ibidem: 06)

A epistemologia convencional de educação de que tratamos, na qual se insere a pedagogia tradicional de letramento referida por Cope e Kalantzis (op.cit.), pode ser lida em termos gerais como o modelo de ensino que organiza, de forma linear, isolada e hierárquica as diferentes áreas de conhecimento e seus respectivos conteúdos.

Tal ênfase ao ensino do conhecimento propositivo predominante nos espaços escolares desde o século XIX advém do próprio pensamento moderno, fundamentado pelo surgimento da Nova Ciência. Trata-se da crise da filosofia metafísica, fundadora da concepção de educação anteriormente ao século XIX, em detrimento do crescente racionalismo cartesiano. Assim, por atribuir tamanha relevância ao conhecimento científico tomado como a peça-chave para a libertação do homem (Marcondes, op.cit.), o paradigma moderno irá moldar a concepção de conhecimento, ensino e aprendizagem dos sistemas educacionais de seu tempo e do século subseqüente.

No que diz respeito ao ensino de línguas no contexto da educação formal, as influências do paradigma moderno da educação também se fizeram presentes, ainda que diversas 
abordagens e métodos de ensino tenham sido desenvolvidos. Uma evidência disso é a identificação da supremacia da concepção de língua como código lingüístico fixo e estável nas três comunidades observadas, tal como fora exposto no Capítulo I, ressalvando-se as devidas diferenças na forma como cada sujeito transpareceu-a.

Em termos práticos, a concepção de conhecimento do pensamento moderno, calcada na ênfase do real e da verdade sobre as coisas, se faz presente a partir do modelo estruturalista de ensino adotado pelas professoras, no qual a interpretação do alunosujeito é fixa e uniforme. Assim, a intenção do autor e o significado das palavras já se encontram prontos em boa parte dessas atividades, cabendo ao aluno apenas reproduzilos, processo este que se constitui a idéia de aprendizagem nesse modelo de ensino.

É o que pudemos identificar nos exercícios de Aida e Sofia, conforme evidenciam as Figuras de 1 a 12, apresentadas ao longo dos capítulos anteriores, e nas atividades desenvolvidas por Beatriz, como o trabalho individual "My pet" (Anexo 2), em que os alunos tinham que responder às perguntas de acordo com um pequeno texto, e o trabalho sobre o Natal (Anexo 3), em que os significados de determinados conceitos já são apresentados por meio da tradução. Convém ressaltar que essa leitura inclui a prática escolar de Sofia que, embora apresente atitudes de ruptura com modelos de ensino convencionais por meio de seu poder de agência, ainda assim faz uso de um modelo estrutural do ensino de inglês, talvez em função das exigências institucionais.

O uso do livro didático, ou no caso, de apostilas bimestrais ${ }^{39}$, nos colégios Teorema e Áureo, corrobora a evidência da concepção moderna de conhecimento nas realidades observadas. Justamente por enfatizar o ensino de conteúdos, a escola convencional vem priorizando o livro-texto desde a invenção da imprensa como objeto de maior valor na sala de aula (Lankshear e Knobel, op.cit.). Trata-se de um objeto valioso, cujas verdades nele inscritas e fixadas levam a um processo de ensino e aprendizagem confortavelmente neutro e estável em boa parte dos casos, e que inviabiliza que os alunos, com seus olhares heterogêneos, construam diferentes interpretações.

\footnotetext{
39 Em contextos de parceria entre instituições, o livro-texto (textbook) vem sendo substituído por apostilas, o que não significa uma mudança na concepção de texto por parte do sistema apostilado.
} 
Em contraposição ao ensino de conteúdos fixos, estáveis e abstratos priorizado por esse modelo convencional de educação, identificado nas práticas pedagógicas das participantes da pesquisa, as transformações emergentes neste novo século abarcam uma outra epistemologia do conhecimento e, conseqüentemente, de pedagogia.

Condizente com preceitos do pensamento pós-moderno, dentre os quais a queda das grandes narrativas modernas em detrimento das contradições e descontinuidades inerentes nas práticas sociais, a epistemologia da era digital entende o conhecimento não mais como um fim em si mesmo, mas pautado na construção, colaboração, distribuição e negociação entre sujeitos em mundos virtuais (Lankshear e Knobel, op.cit:168).

Nesse sentido, propõe-se a quebra de primazia do conhecimento propositivo tradicionalmente posto pela escola e a ênfase ao caráter dinâmico, animado e instável do conhecimento, possibilitado cada vez mais pelas novas tecnologias da informação. Dessa forma, em lugar da priorização do conteúdo concentrado e individualista da epistemologia convencional da modernidade, passa-se a priorizar o conhecimento distribuído (Gee, 2000, 2004) bem como o desempenho dos sujeitos na aquisição e utilização de novas estratégias e habilidades, ou tal como nomeiam Lankshear e Knobel (op.cit.), "a performance epistemology", para falar sobre uma epistemologia que se volta ao saber-fazer na ausência de modelos ou padrões pré-estabelecidos, conforme demanda das novas comunicações e relações da sociedade digital.

O conceito de conhecimento distribuído ${ }^{40}$ de que trata Gee $(2000,2004)$ contrapõe-se ao conceito de conhecimento postulado pelo velho capitalismo. Ao pressupor sistemas lineares, hierárquicos e autoritários nos quais o conhecimento concentrava-se no topo da pirâmide, a engrenagem fordista acabou por moldar uma concepção de conhecimento concentrado que se estendeu na esfera escolar ao longo do século. Diante das transformações tecnológicas recentes e de uma nova lógica de agrupamentos, em que pessoas passam a constituir membros de diversas comunidades ou sistemas de redes, esse conhecimento concentrado cede espaço à priorização de características como

\footnotetext{
${ }^{40}$ Tradução da pesquisadora para o termo original em inglês distributed knowledge (Gee, 2004)
} 
distribuição, colaboração e negociação. Ao tratar do conhecimento distribuído, assim define o próprio autor (2004: 86$)$ :

Distributed knowledge is knowledge that exists in other people, material on the site (or links to other sites), or in mediating devices (various tools, artifacts, and technologies) and to which people can connect or 'network' their own individual knowledge. Such knowledge allows people to know and do more than they could on their own.

Em decorrência dessa ênfase cada vez maior às diversas formas de mediação ou modos de significação, a prioridade com que o livro-texto é tratado no modelo convencional de educação cede espaço às novas formas multimodais de texto presentes nos diversos meios de comunicação, sobretudo a Internet, cujo dinamismo e instabilidade questionam a univocidade de sentido. Ao possibilitar a produção do conhecimento de forma não linear pelo aluno, o próprio conceito de "verdade" do pensamento moderno é igualmente alterado, passando a adquirir um sentido provisório e múltiplo.

Do conceito de língua condizente com essa nova concepção de conhecimento destacamos as contribuições de Bakhtin (op.cit.), mencionadas anteriormente no Capítulo I. Embora situado na década de 20 em termos cronológicos, a concepção bakhtiniana de linguagem se mostra condizente com os preceitos da pós-modernidade e das teorias de letramento, na medida em que compreende todo processo de significação como processo contextualizado, dialógico e ideológico.

Em termos práticos, ao assumir uma concepção heterogênea de linguagem condizente com a teoria pós-estruturalista, as teorias de letramentos implicam, dentre outras questões, a negação do ensino fragmentado nas quatro habilidades, a saber, leitura, escrita, compreensão auditiva e produção oral.

Uma outra implicação refere-se ao tratamento da gramática, a qual passa a ser ensinada em seu contexto de uso, evitando-se, com isso, as abstrações no ensino da língua em função do ensino de regras gramaticais anteriormente ao uso da linguagem, uma 
inversão referida como a 'falácia da regra' por Bourdieu (1977 apud OCEMs, 2006 ${ }^{41}$ ) e que contraria a ordem 'natural' do sistema.

Não podemos nos esquecer de que os novos estudos de letramento emergentes nas últimas décadas ressoam as contribuições da Teoria Crítica e da sociologia da educação, fundamentando-se particularmente, em um primeiro momento, nos preceitos da Pedagogia Crítica.

Ao apresentar novos enfoques epistemológicos em oposição à teoria tradicional ou positivista dominante, a Teoria Crítica postula modelos científicos menos regulares e menos universais, pois pressupõe a diversidade, a descontinuidade e a não linearidade dos fenômenos sociais (Torres, 2003: 14, 15). Busca, portanto, compreender o modus operandi da sociedade como uma totalidade histórica num processo de desconstrução das premissas do senso comum. (Torres, op.cit: 108).

Das implicações da Teoria Crítica para a educação, Torres (op.cit.) menciona o desenvolvimento da crítica aos modelos educacionais pautados na racionalidade instrumental. Trata-se, a nosso ver, do ideário iluminista, cujo principal legado - ou fardo, a depender do ponto de vista do leitor - constitui a ênfase ao ensino de conteúdos.

Fruto das contribuições da teoria crítica, a pedagogia crítica constitui a prática educativa engajada em tal processo de desconstrução e desvelamento, conforme sugere Giroux (1997), para quem a nova sociologia da educação da década de 80 busca repensar a escola dentro de uma linguagem da crítica (ibidem: 39):

As questões centrais para construir-se uma pedagogia crítica são as questões de como ajudamos os estudantes, particularmente aqueles das classes oprimidas, a reconhecerem que a cultura escolar dominante não é neutra e em geral não está a serviço de suas necessidades.

Tendo em vista tais considerações, podemos resumir que a primazia do ensino de conteúdos do modelo convencional de educação cede espaço, na perspectiva das teorias

\footnotetext{
41 Orientações Curriculares para o Ensino Médio (OCEMs, 2006) em substituição aos Parâmetros Curriculares Nacionais (PCNs).
} 
de letramentos, à concepção de conhecimento dinâmico, distribuído e colaborativo, calcado numa linguagem da crítica.

No âmbito da sala da aula, isso significaria ensinar a língua inglesa de forma contextualizada à realidade dos alunos, possibilitando que estes desenvolvam outros olhares acerca dos diferentes modos representacionais da linguagem presentes em seu entorno, tais como textos, imagens, gráficos, sons. Para ilustrar o que queremos dizer, recorreremos a uma atividade descrita por Beatriz, professora da EMEF:

Beatriz: essa aqui por exemplo... foi um trabalho com texto... tinha as frases:: eles tinham que fazer a tradução:: e eu já passei o vocabulário porque senão eles levariam muito tempo pra pesquisar mas já ensinei como se usa o dicionário... é só pra ir agilizando né? ...aí tem a segunda parte... pegar as mesmas frases em inglês e separar pelos personagens... são frases de cada um dos três personagens... só que antes de fazer a atividade eu mostrei a figura... eu arrumei figuras de mulher:: de homem:: uma mais nova:: uma de meia-idade:: um mais velho:: e arrumei figuras referentes aos empregos de cada um... o hospital:: o caminhão:: isso mostrando pra eles terem uma idéia do texto antes de trabalhar com a parte escrita...eu mostrei as figuras:: falei:: depois entreguei a folha:: e no final de tudo eu pus as frases na lousa pra nós lermos.

O objetivo de Beatriz constitui essencialmente o ensino de vocabulário. Sob a perspectiva de uma teoria de letramentos, no entanto, a qual pressupõe a construção crítica de outras significações que não aquelas do senso comum, poder-se-ia explorar a questão dos estereótipos usualmente (re)construídos nas aulas de inglês para o ensino do vocabulário de profissões.

Assim, em lugar da simples associação entre determinados estereótipos e profissões (eu arrumei figuras de mulher:: de homem:: uma mais nova:: uma de meia-idade:: um mais velho:: e arrumei figuras referentes aos empregos de cada um... ${ }^{42}$ o hospital: o caminhão::), uma outra forma de abordar a questão para além do ensino de vocabulários isolados seria convidar os alunos a questionarem essas associações padronizadas do senso comum entre certos estereótipos estampados na mídia e certas profissões, indagando-os, por exemplo, ao mostrar a figura da mulher: "O que vocês acham que ela faz? Onde ela trabalha? Por que vocês acham que ela tem essa profissão? Com quem

${ }^{42}$ Grifos nossos. 
essa pessoa se parece? Com quem ela não se parece? Vocês conhecem alguém que tenha essa mesma profissão? Essa pessoa gosta do trabalho? Por que (não)?

A abordagem proposta acima é referida por Cervetti, Pardales e Damico (2001) no bojo das pesquisas sobre letramentos. Ao exemplificarem o trabalho pedagógico sob a ótica do letramento crítico, os autores sugerem a elucidação de perguntas como: Quais são os possíveis significados a serem construídos a partir desse texto? Para quem ele se dirige? Para quem ele não se dirige? Que visão de mundo é apresentada pelas idéias do texto? Que visões não são explicitadas? E assim por diante.

A mesma análise sob a perspectiva dos letramentos pode ser realizada em outra prática de Beatriz, ao final do ano letivo, em que a professora propõe uma atividade de Natal (Anexo 3). Após ter mostrado algumas figuras e praticado a pronúncia de cada palavra, como Christmas tree, gifts, Santa Claus, a professora entregou uma folha com uma lista de vocabulário de Natal e outra folha com uma cruzadinha (Figura 13):

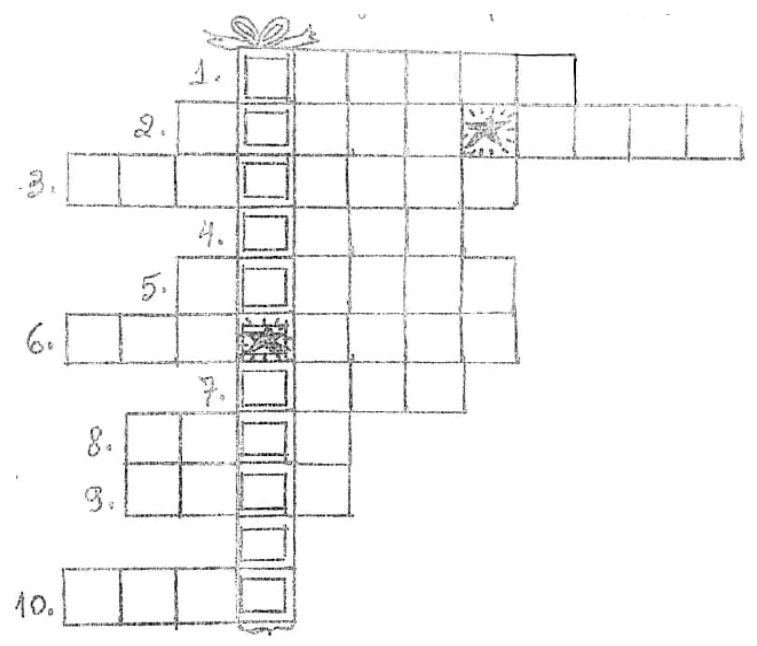

\begin{tabular}{c|c|c|c|c}
\hline 1. TRENO & 2. BENGALINAA DOCE & 3. RENA \\
\hline 4. ÁRVORE & 5. VELA & 6. ANO NOVO & 7. CARTÃO \\
\hline 8. SINO & 9.ESTRELA & 10.BRINGVEDOS \\
\hline
\end{tabular}

Figura 13: cruzadinha referente à atividade sobre Natal, extraído do Anexo 3 . 
Durante essa aula, chamou-nos a atenção o fato de a professora ensinar aos alunos palavras que certamente não fazem parte de suas realidades, como por exemplo sleigh, reindeer, stocking e candy cane.

Naturalmente, a representação de Natal retratada na sala de aula de Beatriz já se constitui um habitus em diversas culturas, ainda que certas representações não façam parte do dia-a-dia de tais culturas. Na aula de Beatriz, a evidência da falta de tratamento quanto às diversidades locais e diferenças culturais pôde ser notada quando a professora elucida o significado de stocking, fazendo referência à lareira, não muito típica em nossos contextos:

Beatriz: essa meia muitas pessoas penduram sobre a lareira. Alguém sabe como se fala em inglês? STOCKING.

O que Beatriz talvez não tenha percebido e que se constitui um interessante fato para nossa análise refere-se à indisciplina e desinteresse dos alunos durante a atividade de Natal em contraste com um repentino interesse da parte de alguns alunos quanto a um outro assunto suscitado nas conversas paralelas, no caso, as traduções de seus nomes para o inglês. O tema é expandido a outros grupos e, ao final da aula, os alunos encontram-se todos posicionados ao redor da mesa da professora, questionando:
A1: Professora, como fica Anderson em inglês?
Beatriz: Anderson já é em inglês. Não tem no português.
A2: E Ademar?
Beatriz: Ademar é em português.

Ou seja, diante da representação generalista e autoritária do Natal, retratada na mídia e reproduzida de forma acrítica em alguns contextos de sala de aula, são justamente as diversidades culturais locais e as conectividades globais assinaladas pelos novos estudos de letramento que mais instigam os alunos a produzirem relações entre a língua materna e a língua estrangeira.

Acreditamos que esse tipo de enfoque possa levar os alunos futuramente a ficarem mais atentos quanto ao fato de que as imagens em seu entorno, tal como os textos escritos, significam algo. Assim, as atividades acima não deixam de constituir brechas para que professores, sob a perspectiva dos letramentos, possam questionar a univocidade de 
sentidos pretendida nos diferentes modos de significação, transformando o ambiente de sala de aula numa arena política e cultural em que diferentes formas sociais e ideológicas pudessem ser refletidas (Pennycook, 1994: 297).

Diante de implicações tão significativas, entendemos que as re-conceituações de conhecimento, de linguagem e de educação que as teorias de letramentos vêm assinalando nas últimas décadas podem ser pensadas mais detidamente no bojo da discussão sobre ensino e aprendizagem de línguas, como forma de contribuir para a emergência de novas práticas pedagógicas, dentre as quais a prática avaliativa.

\subsection{Repensar a avaliação sob a perspectiva dos letramentos}

A ênfase ao conhecimento propositivo bem como o caráter individualista do conhecimento concentrado postulado pelo modelo epistemológico convencional de educação de que tratamos anteriormente tem possibilitado a perpetuação de uma concepção de avaliação pautada na verificação de objetivos devidamente alcançados por meio de formas avaliativas que privilegiam ainda aspectos como validade ${ }^{43}$, fidedignidade ${ }^{44}$ e confiabilidade, tipicamente relacionados com a filosofia positivista.

Isso pode ser depreendido na medida em que a representação de conteúdo do modelo convencional de educação abarca características bastante desejáveis para uma avaliação tida como válida e fidedigna. Trata-se do ensino de conhecimentos sobre o que já existe, portanto, verdadeiros, fixos, estáveis. Tal fixidez e estabilidade dos conteúdos permitem aos professores medirem a aquisição de conhecimento por parte de seus alunos sem dificuldades, por meio de instrumentos avaliativos precisos e objetivos. Em um exercício de leitura, por exemplo, qual aluno, em momento avaliativo, hesitaria em arriscar diferentes interpretações frente ao enfoque comumente dado à intenção do autor e, conseqüentemente, à univocidade do texto?

\footnotetext{
43 Trata-se do "grau pelo qual as notas dum teste permitem tirar conclusões adequadas, significativas e úteis, em relação com o objectivo do teste" (Milanovic 1998 apud Fidalgo, 2002: 13)

${ }^{44}$ A fidedignidade ou confiabilidade em testes educacionais refere-se à consistência ou estabilidade das medidas de um teste, considerado confiável se seus resultados forem consistentes em diferentes situações de exame (Bachman \& Palmer, 1996 apud Fidalgo, 2002: 13)
} 
Historicamente, Cope e Kalantzis (op.cit.: 11) explicam que a própria concepção de trabalho postulado pelo Fordismo do início do século XX possibilitou a difusão da relevância de conceitos como objetividade e precisão, na medida em que suas produções em série pressupunham o trabalho mecânico, linear, simétrico, donde a linguagem requisitada era caracterizada por sistemas de comando formais, claros e altamente precisos.

Nesse sentido, os autores (ibidem: 140) relacionam a concepção fordista e o apogeu dos Estados nacionalistas ao ensino da norma culta, no caso, ao tratamento privilegiado da variação lingüística da classe dominante, como forma de garantir uma comunidade nacional homogênea: "In this process, there were clear rights and wrongs, standards and non-standards, literatures and less-than-literatures." A avaliação como sinônimo de mensuração objetiva e precisa do conhecimento constitui, portanto, a concepção de avaliação que mais atende a esse ensino padronizado da norma culta e que ainda se faz recorrente, conforme mostram as análises das práticas avaliativas das professoras, explicitadas no Capítulo II.

Diante dessas considerações, voltamos ao questionamento central da pesquisa: como pensar a avaliação da aprendizagem à luz dessa nova base epistemológica do conhecimento de que tratam as teorias de letramentos? Na medida em que as verdades absolutas e estáveis dos conteúdos ensinados sob a ótica da epistemologia convencional de educação do paradigma da modernidade já não condizem mais com a nova epistemologia digital, como vislumbrar uma nova concepção de avaliação se ainda nos encontramos inseridos num modelo tradicional de ensino, imbricado de uma concepção de avaliação como sinônimo de mensuração, portanto, adepta a tudo que é real e estável? Quais conteúdos seriam abarcados, que propósitos seriam delineados e quais modalidades de avaliação mostrar-se-iam mais adequadas com uma pedagogia de multiletramentos?

Respostas acabadas inexistem, mas acreditamos que algumas concepções teóricas de que tratamos anteriormente possam oferecer alguns insights para o processo de resignificação da avaliação da aprendizagem no que tange ao conteúdo, à caracterização e às modalidades avaliativas. 


\subsubsection{A re-significação do conteúdo a ser avaliado}

Cope e Kalantzis (op.cit.: 147) contribuem para a re-significação da prática avaliativa ao mencionarem as novas ênfases da pedagogia de multiletramentos, dentre as quais as diversidades locais e as relações interpessoais. Ao tratarem especificamente da justaposição do público e do privado e da quebra de uma visão binária de ambas as esferas, os autores destacam a questão da subjetividade:

The personalising of the public and the making public of the personal could present productive interrelational possibilities. It introduces subjectivity - desires, interests, affect - into realms previously dominated by the hidden agendas of instrumental rationality and abstract systems.

Os autores (op.cit: 148) fazem referência a uma "pedagogia do pluralismo", cuja palavra-chave constitui a diferença e o tratamento de suas formas em relação aos seus contextos culturais locais, o que implica levar em conta questões como: De onde 'fala' o texto? Quais são suas múltiplas fontes? O que ele faz? Como ele faz? Para quem ele é direcionado? Como podemos lê-lo?

Lankshear e Knobel (op.cit.), por sua vez, caracterizam a nova base epistemológica de conhecimento diante da ênfase à criação e recriação, cada vez mais possibilitadas pelos aparatos eletrônico-digitais. Ao tratar das implicações dessa epistemologia da era digital, os autores (op.cit.: 159) questionam:

What is now involved in photographic knowledge, in judging the quality of images, in knowing how 'true' an image is and so on? What are the implications for evaluative criteria, for participation in fine arts? What constitutes colour? What is our concept of colour once we have to think in terms of bits, resolution, software trade-offs and the like ${ }^{45}$

Os questionamentos dos pesquisadores (op.cit.) dizem respeito a um modo específico de linguagem, a linguagem visual, cuja significação passou a ser alterada em função do

\footnotetext{
${ }^{45}$ Grifos nossos.
} 
desenvolvimento de aparatos eletrônicos sofisticados, no caso, as câmeras digitais e todas as possibilidades de produção que elas ensejam.

Da mesma forma que Lankshear e Knobel atentam para a necessidade de repensar os critérios a serem adotados para se avaliar a qualidade de uma imagem fotográfica, podemos igualmente assinalar nossa preocupação com os critérios de avaliação da aprendizagem de uma língua estrangeira na perspectiva dos novos estudos de letramento. Isso porque o abalo de categorias convencionais pela possibilidade de novas representações implica a mudança de critérios avaliativos: como julgar a qualidade de uma produção escrita, por exemplo, se o conceito de qualidade é móvel diante das diversidades? Como julgar a verdade das produções dos alunos se o conceito de verdade agora passa a ser provisório?

Antecipamo-nos a esclarecer que não entendemos o conceito de subjetividade e de verdades provisórias numa prática de "vale-tudo", em que se suspendem todos os critérios de avaliação, uma leitura restrita sobre o lugar que a subjetividade tem em qualquer prática social, incluindo-se a pedagógica. Ao assumirmos os preceitos da teoria crítica, entendemos que a validade das produções dos sujeitos advém do contexto de uso no qual se inserem e do próprio processo de negociação entre os mesmos.

A esse respeito, Lyotard (apud Lankshear e Knobel, ibidem), inserido no debate da queda das grandes narrativas, aponta que as verdades cedem lugar a idéia de usos. Assim, conceitos binários como 'falso e verdadeiro', 'justo e injusto', 'correto e incorreto' não mais encontram respaldo na epistemologia da era digital, uma vez que o conhecimento verdadeiro deixa de ser um fim em si mesmo. Assim é que, na visão de Lankshear e Knobel (ibidem: 169), a verdade passa a ser multi-modal. A questão central e problematizadora, no entanto, está em saber como ela se dará, tal como a própria indagação dos autores parece elucidar: “(...) how do we make sense of truths that are expressed not in propositions but through multiple media simultaneously and interactively?"

Da mesma dificuldade em pensar critérios de avaliação sob a perspectiva dos novos letramentos trata Kleiman (2004: 218), ainda que o questionamento da autora esteja inserido na discussão acerca de testes de domínio da língua escrita. Ao tomar o texto 
como uma questão aberta posta ao aluno e ao reconhecer as "bagagens ideológicas" dos sujeitos testados, a autora diz:

(...) uma questão importante a se discutir é a legitimidade de delimitar um conjunto preferivel, 'correto' de textos com que o sujeito testado pode estabelecer relações intertextuais num teste de compreensão da escrita.

Tendo em vista tais contribuições, achamos possível esboçar provisoriamente outras abordagens de avaliação que vão além da simples verificação de conteúdos fixos e memorizáveis, dada a ênfase à subjetividade, à diferença e à criação de que tratam Cope e Kalantzis (op. cit.) e Lankshear e Knobel (op.cit.).

Consideremos, por exemplo, o exercício 1 (Figura 14) do Anexo 7. Trata-se de um texto sobre Fred King, um personagem fictício, cujo conteúdo transcrevemos a seguir:

Fred King is tall and handsome. He isn't fat and he isn't thin. He's got short fair hair and green eyes. His age is a secret. Fred is a famous American actor. He's very rich. He's got a beautiful new car. It's a Porsche. His house is large and comfortable. It is locates in a rich section of Los Angeles.

Fred isn't married. He's got a girlfriend. Her name is Vanessa. She is a pretty top model. She's very tall and thin. She's American too.

1- Here are Fred's answers. Write the interviewer's questions:

Figura 14: exercício de formulação de perguntas, extraído do Anexo 7.

O exercício proposto por Sofia solicita que os alunos formulem perguntas de uma entrevista com Fred, cujas respostas já são fornecidas. Trata-se da avaliação da estrutura da língua, no caso, a formulação de perguntas, em que Sofia possivelmente testou o uso de Wh-words, verbos auxiliares e conjugação verbal. 
Percebemos, nesse contexto específico, uma possibilidade de trabalho com letramentos cuja avaliação incluiria não apenas o conteúdo lingüístico, mas também, e principalmente, a discussão crítica acerca do texto, priorizando questões como a quem ele se dirige, a quem ele não se dirige, por quem ele foi escrito, que visão de mundo ele encerra.

Esse trabalho é potencializado na medida em que o exercício prioriza determinados modelos sociais voltados ao tipo físico, estilo de vida social e material (vide trechos em negrito na Figura 14), muito condizentes com o estilo de vida de sociedades neoliberais, modelos esses difundidos nos mais diversos modos de comunicação, como a Internet, a $\mathrm{TV}$, as rádios, as propagandas, os produtos de consumo. Se levarmos em conta o fato de que estes alunos mantêm contato direto com tais modos de significação, e conseqüentemente com modelos estereotipados, um trabalho de letramento crítico nesse contexto poderia trazer interessantes implicações no processo de produção de conhecimento desses alunos, provocando-os ao exercício de reflexão crítica sobre o tema referido e outros afins.

Dessa forma, ao serem avaliados sob a perspectiva dos letramentos, e diante de um trabalho de mediação por parte do professor, os alunos poderiam criar aos poucos outras formas de ver o mundo, lendo imagens em outdoors, revistas, jornais, livros didáticos, páginas da Internet, televisão e vídeo com outros olhares, conscientizando-se de que em seu entorno encontram-se outros modos de significação para além do texto escrito.

A imagem do modelo da família feliz (Figura 15) em um outro exercício da mesma prova (Anexo 7) constitui uma outra brecha para esse exercício de letramento. A atividade tem por objetivo avaliar o conhecimento dos alunos quanto ao uso de adjetivos possessivos em inglês, ao solicitar que preencham as lacunas do texto sobre a família da foto (vide anexo). Assim, o exercício mecanicista de preenchimento de lacunas com conteúdos fixos e estáveis mais uma vez corrobora a identificação da concepção de avaliação do paradigma da modernidade. 


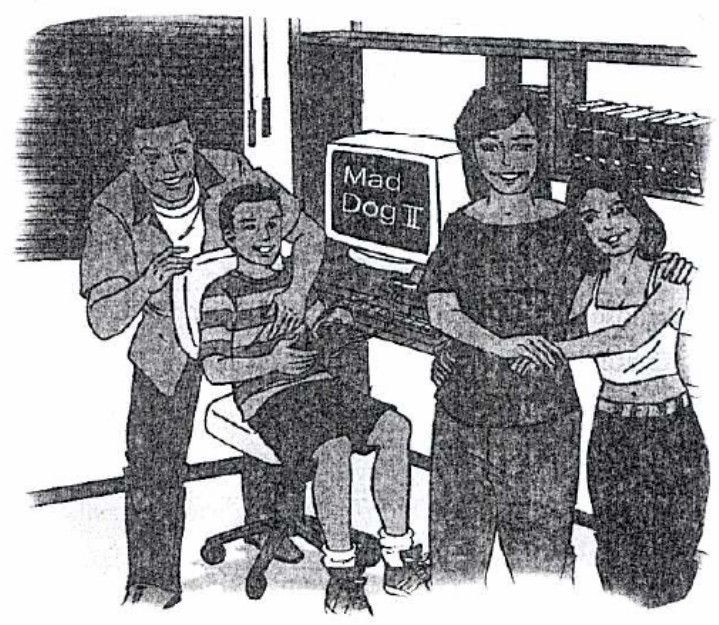

Figura 15: ilustração como parte integrante do exercício 2, extraída do Anexo 7.

Se tomado por outro viés, no entanto, o mesmo exercício possibilitaria uma avaliação mais ampla, que abarcasse não apenas a verificação do uso correto dos conteúdos gramaticais, mas sobretudo as produções de sentidos e os posicionamentos ideológicos dos alunos diante do exercício. Sob essa perspectiva, o uso da imagem como mera ilustração cederia espaço à concepção de imagem como um modo de representação (Cope e Kalantzis, op.cit.), donde se pressupõe a possibilidade de ler e interpretá-la tal como usualmente se faz com textos escritos. Tal leitura poderia suscitar interessantes questionamentos, dentre os quais: "Qual a concepção de família sugerida na imagem?”, "Essa figura retrata as famílias que você conhece?", "Por que (não)? Justifique sua resposta". E assim por diante.

Convém esclarecer que nosso entendimento acerca do que vem a constituir o 'crítico' não se insere na visão liberal-humanista de leitura crítica (Cervetti et al, op.cit.), mas sim, no conceito das teorias de letramento crítico.

Cervetti et al (op.cit.) discutem a diferença entre critical reading e critical literacy. Em suas análises, o conceito de leitura crítica (critical reading) se fundamenta na tradição liberal-humanista e requer do leitor o discernimento neutro e racional entre fatos, opiniões e julgamentos pessoais; já o letramento crítico (critical literacy) prevê a multiplicidade de sentidos num texto por ser este cultural e historicamente situado, portanto, desprovido de neutralidade. Ambas constituem interessantes abordagens, embora apresentem objetivos educacionais distintos. 
Ao tratarem de tal distinção, os autores afirmam que enquanto o ensino da leitura crítica pretende o desenvolvimento da habilidade de compreensão e interpretação textual de forma linear e racional, conforme sugerem os exercícios das atividades das professoras, o letramento crítico pressupõe o desenvolvimento da consciência crítica. Burbules e Berk (1999), por sua vez, contribuem para a compreensão da diferença entre este e o conceito de leitura crítica, destacando sua ênfase na elucidação de questões sociais.

Retomando nossa análise, o exercício 1 do Anexo 8 também possibilita repensarmos a avaliação no contexto dos estudos de letramentos. Nesse exercício (vide anexo), os alunos devem ler um texto intitulado "Teen Lives", escrever respostas completas de acordo com sua compreensão e, por fim, completar uma tabela com informações sobre a rotina da personagem do texto, Sharon (exercício 2 da mesma prova).

Embora Sofia utilize textos em suas provas, a professora o faz como forma de avaliar o aprendizado de estruturas gramaticais, ou seja, o aprendizado de conteúdos fixos e verdadeiros, tal como pode ser depreendido das perguntas: How old is Sharon? Where is Sharon's mother from? Who is Steve? Where do Steve and Sharon go in the evening?

Ao fazer sugestões quanto à formulação de perguntas que atendam a uma ação reflexiva e crítica da avaliação, Álvarez Méndez (op.cit.: 117) não nos fornece técnicas e receitas prontas, mas contribui para a questão ao afirmar que:

Aquelas perguntas que tenham a mesma resposta entre os alunos podem ser descartadas, pelo fato de que costumam basear-se nos mesmos apontamentos, na mesma fonte de informação e só requerem o esforço da memória comum, circunstancial, mínima, a curto prazo e não-significativa.

Destarte, no bojo da discussão acerca do conteúdo que se pretende avaliar, uma avaliação na perspectiva dos letramentos possivelmente abarcaria perguntas que ressaltassem a criação e recriação das significações dos alunos para além do simples processo de cópia ou paráfrase em que os alunos retiram os trechos prontos nos textos ou elaboram respostas corretas e padronizadas, como se estas já estivessem presentes no texto per se. Assim, do ponto de vista dos estudos de letramento, e no caso da utilização do mesmo texto, poderíamos pensar em questões como "Sharon se parece com as jovens 
de 14 anos que você conhece?"; "O que facilita que ela faça homeschooling?; "Há homeschooling no Brasil?", "Isso seria possível? Justifique sua resposta”.

Entendemos que ao propor esse tipo de pergunta, o professor avalia não apenas conteúdos acabados, mas também a forma como alunos se posicionam diante dos modos de significação e como negociam os sentidos dos textos, possibilitando inclusive a desconstrução de significados. Isso porque o próprio texto do exercício tem como título "Teen Lives", dando-nos a impressão de que irá tratar de adolescentes de forma generalizada; ao lermos o texto, no entanto, percebemos que traz um estilo de vida muito peculiar de uma jovem privilegiada por poder estudar em casa (homeschooling), por uma perspectiva,; ou de uma adolescente desprovida da oportunidade do convívio amplo em uma comunidade de jovens, por uma outra perspectiva.

Utilizemos, como último exemplo, uma atividade elaborada por Beatriz (Anexo 2). O trabalho, intitulado "My Pet", tem por objetivo avaliar conteúdos gramaticais (no caso, o enfoque é o tempo verbal Presente Simples) e conteúdos lexicais, por meio da tradução do texto (Figura 16). Num segundo momento, os alunos devem produzir um trabalho individual, desenhando seus próprios animais de estimação e respondendo a dez perguntas. Àqueles que não têm um animalzinho, a professora respondeu: "Pessoal... se vocês não têm um animal de estimação imaginem que vocês têm." "46

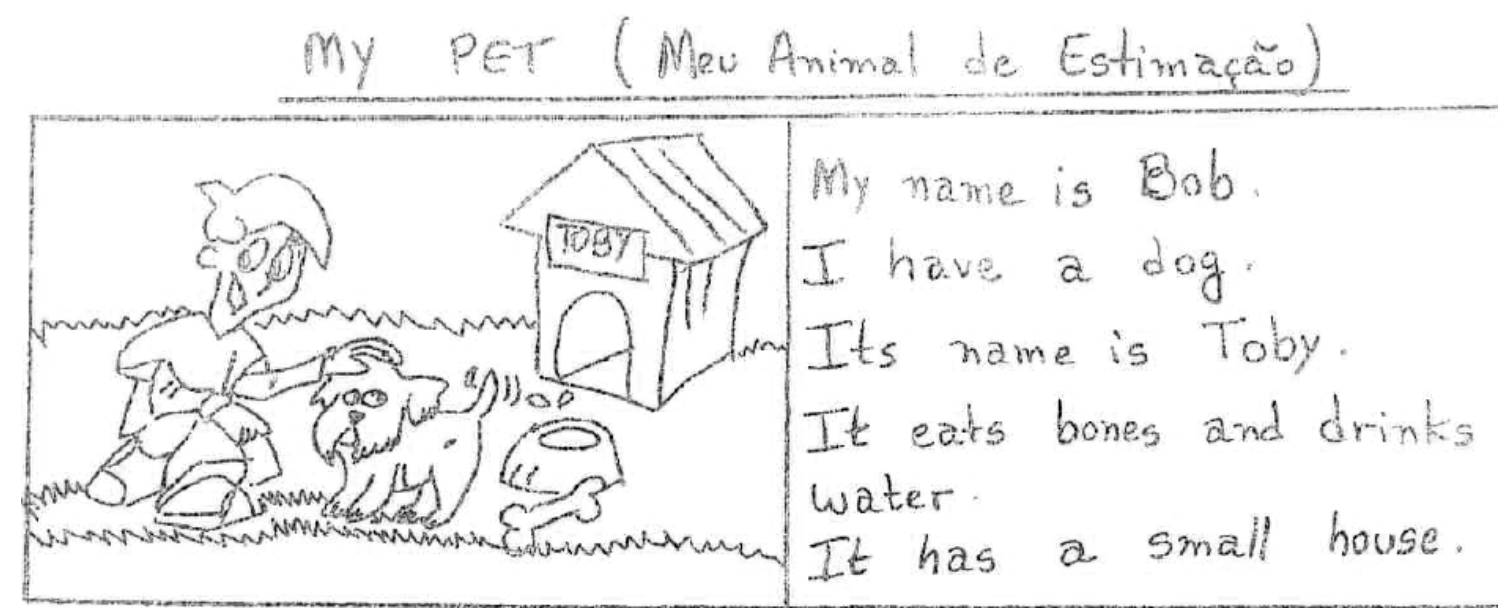

Figura 16: ilustração e texto referente à atividade "My Pet", extraída do Anexo 2.

\footnotetext{
${ }^{46}$ Anotação de campo.
} 
O desenho mostra uma criança feliz ao lado de seu cachorro. Note-se, também, na figura, todo o aparato usualmente vendido em pet shops como a casinha com o nome do cachorro nela inscrito, o recipiente de água e o osso. Com relação às perguntas sobre os animais de estimação dos alunos, destacamos as duas últimas: "Does it have a special house?" e "Does it stay in your house or in your yard? (vide anexo). Considerando o fato de muitos alunos da EMEF serem moradores de favelas e bairros mais simples daquela região, questionamos o quão eles se identificam com a figura acima; similarmente, questionamos a adequação das questões postas pela professora, já que muitos deles certamente não possuem um quintal em suas casas.

Pensar a forma de avaliação para essa atividade tal como foi proposta torna-se fácil, na medida em que a professora objetiva essencialmente verificar o entendimento dos alunos quanto ao texto por meio da tradução; dessa forma, a atividade pressupunha respostas fáceis de serem medidas e corrigidas, por meio da verificação objetiva da utilização de termos previamente oferecidos no próprio exercício. Sob a ótica dos letramentos, no entanto, outras perguntas poderiam ser explicitadas, que priorizassem a subjetividade, o conhecimento distribuído e a possibilidade de criação e recriação de sentidos sobre o texto ${ }^{47}$, a exemplo das que explicitamos nos exercícios anteriores. Trata-se, porém, de uma tarefa cuidadosa, cujos questionamentos a serem propostos aos alunos são merecedores de um bom planejamento e uma abordagem adequada ao seu contexto de uso.

\subsubsection{Características da avaliação segundo os letramentos}

Ao tomarmos, pois, a concepção de conhecimento distribuído e dinâmico postulada por teóricos como Gee (op.cit.), acreditamos que uma possível concepção de avaliação da língua inglesa nessa nova perspectiva deva constituir-se distribuída, colaborativa, situada e negociada. Assim, uma "avaliação distribuída e colaborativa" abarcaria, por exemplo, a possibilidade de alunos e professores compartilharem suas apreciações e deliberações, tornando-as mais públicas e menos verticalizadas, em detrimento dos momentos avaliativos formais no modelo convencional de ensino. Quanto à sua natureza situada e negociada, referimo-nos à priorização do conceito de verdades

\footnotetext{
${ }^{47} \mathrm{O}$ texto tomado aqui não apenas em sua forma verbal, pois consideramos como texto a imagem visual, no caso, a figura apresentada no exercício.
} 
provisórias e a idéia de validade móvel, a qual passaria a emergir do próprio contexto no qual os sujeitos se inserem.

Há, ainda, que se considerar como outro elemento chave da avaliação segundo os letramentos a questão da criação (design), donde se pressupõe considerar determinados aspectos, como a subjetividade, os interesses, as intenções, os comprometimentos e propósitos dos alunos diante de seus processos de aprendizagem (Cope e Kalantzis, op.cit.: 18).

Com relação aos propósitos avaliativos, buscamos novamente em Cope e Kalantzis (op.cit.: 33) alguns insights, uma vez que os autores explicitam que a avaliação deva guiar os alunos nas experiências para o desenvolvimento de habilidades, possibilitandolhes promover contribuições em suas comunidades de prática, em detrimento de mero julgamento de suas ações. Assim, no que diz respeito especificamente aos propósitos da avaliação da aprendizagem, as teorias de letramentos parecem abarcar o conceito de avaliação formativa desenvolvido ao final do século XX por este priorizar aspectos como processo, acompanhamento e dinamismo.

Julgamos pertinente esclarecer o conceito de 'comunidades de prática' a que se referem Cope e Kalantzis (op.cit.) e outros teóricos afins. Termo bastante recorrente no campo das pesquisas sobre letramentos, as comunidades de prática constituem grupos de pessoas que compartilham um determinado conjunto de práticas, em cujo processo uns aprendem com os outros. Assumida por Gee (2004: 98) como peça importante na noção de aprendizado da sociedade contemporânea, as comunidades de prática acabam por promover uma interessante ruptura de idéias estanques e estereotipadas, na medida em que seus membros não mais são agrupados por questões de classe, gênero ou raça, mas por suas afinidades, seus objetivos e interesses comuns. Exemplos de comunidades de prática constituem as salas de bate-papo, o MSN Messenger e o Orkut, a comunidade virtual de amizades (OCEMS, op.cit).

No que tange às implicações do conceito de comunidades de prática para o ensino de língua inglesa, podemos afirmar que este vem corroborar a relevância de se compreender a linguagem e a cultura como variantes locais, cujas regras são determinadas em seu contexto de uso (OCEMs, op.cit: 103). Isso significa ensinar e 
avaliar a língua de forma particularizada e significativa para aquela determinada comunidade de prática. Além disso, trata-se de um conceito novo de agrupamento cuja inclusão nas aulas poderia suscitar a transformação conceitual do que professores e alunos entendem por conhecimento, já que as comunidades de prática priorizam seu caráter distribuído, colaborativo e dinâmico.

\subsubsection{Redesenhando algumas modalidades da avaliação}

O conceito de comunidade de prática, aliado às outras concepções postuladas pelas teorias de letramentos explicitadas anteriormente, possibilita-nos repensar algumas modalidades de avaliação já existentes de forma que nos pareçam mais condizentes com as recentes transformações na base epistemológica de conhecimento e educação.

Referimo-nos especificamente às contribuições advindas do campo da avaliação a partir dos anos 80 quanto ao desenvolvimento e divulgação de instrumentos alternativos que, àquela época, voltavam-se para o emergente caráter formativo da avaliação. Dentre estes instrumentos, destacamos o portfolio por se tratar de uma modalidade de avaliação cujo formato revelou-se bastante inovador diante da primazia das provas escritas que perpassou o século XX.

O uso de portfolio em salas de aula começou a ser discutido em meados da década de 80, época em que teóricos do campo educacional iniciaram um questionamento acerca das implicações da avaliação da aprendizagem autoritária, classificatória e excludente predominante ao longo do século XX. Advinda do campo da arte (Vieira, 2002), trata-se de uma modalidade de avaliação cujo desenvolvimento fundamentou-se inicialmente na abordagem construtivista. Isso porque a centralidade do aluno postulada pelos construtivistas não mais condizia com instrumentos avaliativos autoritários, como era o caso das provas escritas ou dos testes de múltipla escolha, havendo, portanto, a necessidade de pensar formas alternativas de avaliação.

Assim, definido por Hernandez (1998, apud Vieira, ibidem) como um "continente ${ }^{48}$ de diferentes classes de documentos (notas pessoais, experiências de aula, trabalhos

\footnotetext{
${ }^{48} \mathrm{O}$ autor utiliza o termo continente como sinônimo de 'lugar', podendo ser este de caráter físico-material ou não, dada a existência e o uso incisivo de aparatos eletrônicos da nova era digital.
} 
pontuais, controle de aprendizagem, conexões com outros temas fora da escola, representações visuais, etc)", o portfolio enfatiza o processo de aprendizagem do aluno ao longo de um dado período, assumindo um caráter formativo. A centralidade do aluno é evidenciada na medida em que é ele quem organiza e decide sobre as atividades que quer incluir ou não em sua "pasta avaliativa” (Villas Boas, 2001, apud Vieira, op.cit.), deliberando, juntamente com o professor, sobre o seu próprio desempenho escolar.

O portfolio como instrumento alternativo de avaliação ao final do século apresenta, portanto, algumas importantes características em geral negligenciadas pelas provas escritas, dentre as quais a ênfase ao diálogo entre professor e aluno no processo avaliativo; o incentivo à participação e tomada de decisão do aluno e, principalmente, o compromisso com a formação reflexiva do aluno, com vistas a desenvolver sua consciência sobre o que aprendeu e como aprendeu (Vieira, op.cit.).

Diante dessa caracterização, entendemos que o uso do portfolio como ferramenta de avaliação constituiu-se uma alternativa muito condizente com o discurso de denúncia dos teóricos do campo da avaliação a partir da década de 80, na medida em que engendrou atitudes educativas menos verticalizadas e centralizadoras (Villas-Boas, 2005).

No entanto, ao considerarmos nosso lócus de crítica, ou seja, as teorias de letramentos, o que nos salta aos olhos na análise das definições e propósitos do portfolio constitui o fato de que, ainda assim, trata-se de um instrumento essencialmente embasado em fundamentos biológicos, dada sua ênfase à formação reflexiva do aluno tanto com relação ao conteúdo que aprendeu quanto com relação à forma como aprendeu.

A evidência dessa base psicológica fundadora da idéia de portfolio pode ser inferida dos exemplos de atividades apresentados por Paris e Ayres (1994). De um modo geral, as tarefas pedem aos alunos para listarem todos os seus trabalhos do portfolio, relatarem qual é seu trabalho preferido, as razões de sua preferência, o que ele acha que aprendeu, o que ele acha que poderia melhorar, dentre outras questões. Em nossa leitura, trata-se de uma abordagem voltada essencialmente aos processos individuais de aprendizagem. 
Aliás, essa prioridade ao aspecto individual é também recorrente na própria concepção de sujeito que a idéia de portfolio abarca. Ao propor a autonomia do aluno e o tratamento individualizado, o conceito de portfolio parece vir imbuído de uma concepção humanista-liberal de indivíduo. Isso porque tudo gira em torno do aluno, não havendo priorização da produção de conhecimento nas relações sociais ocorridas na própria sala de aula, mas, sim, na relação aluno-portfolio-professor, sendo o portfolio uma espécie de mediador.

A concepção humanista-liberal do indivíduo que o portfolio encerra parece condizer com o conceito de sujeito-porfolio ${ }^{49}$ apresentado por Gee (2004), sobre o qual convém problematizar.

Segundo o pesquisador (ibidem), o novo capitalismo neoliberal tem projetado uma concepção de sujeito em concordância com as transformações tecnológicas recentes com ênfase para características como mobilidade, necessidade de adaptação, flexibilidade, dinamismo, colaboração, muito em função da própria re-significação do conhecimento de que tratamos anteriormente.

Assim, diferentemente do sujeito do velho capitalismo fordista, o sujeito-portfolio define-se como sujeito empreendedor, na busca da construção de suas próprias habilidades, experiências e realizações (Gee, op.ti.: 105) da forma mais diversificada possível, garantindo a si mesmo um bom apanhado de aprendizados diversos, ou seja, um portfolio ampla e ricamente diversificado, advindos de fontes de recursos para além da esfera escolar.

Diante dessa caracterização, a idéia de sujeito-portfolio mostra-se adequada às transformações atuais, atendendo de forma consistente à noção de multiletramentos. Gee (op.cit.), no entanto, ao situar o conceito de sujeito-portfolio no modelo neoliberal, promove sua crítica justamente por mostrar que nem todos têm as mesmas condições de construir portfolios sociais ampla e ricamente diversificados, contrariamente à demagogia neoliberal de "oportunidades para todos". A própria política de conteúdos mínimos na esfera pública de ensino, ou "learning the basics" se utilizarmos as palavras

\footnotetext{
${ }^{49}$ Do termo original em inglês portfolio people (Gee, 2004).
} 
do próprio autor (op.cit.: 109), faz ressoar essa desigualdade de oportunidades entre os sujeitos.

Desse modo, identificamos uma contradição no conceito de sujeito-portfolio, com possibilidade de interpretações distintas, na medida em que, embora condizente com as transformações da era digital, o não comprometimento das políticas educacionais com projetos que, de fato, ofereçam oportunidades iguais a todos, sobretudo no âmbito da esfera pública, acaba por tornar a desigualdade social ainda mais veemente, corroborando, de um lado, a formação de sujeitos com portfolios abastados; e de outro, a formação de sujeitos com portfolios ralos, por se encontrarem desprovidos de possibilidades para o desenvolvimento de habilidades, experiências e realizações amplamente variadas. Assim é que o conceito de sujeito-portfolio pode atender a propostas de educação divergentes, a depender de suas características e propósitos num contexto educacional específico.

Ao retomarmos o conceito de portfolio como instrumento avaliativo, concluímos que, embora tipicamente tomado como instrumento formativo por excelência, o portfolio amplamente difundido nos anos 90 fundamenta-se por preceitos essencialmente psicológicos, limitando-se a um plano individual. Tais limitações instigam-nos a buscar um outro conceito de portfolio que, mantendo seu compromisso formativo e reflexivo, pudesse expandir para além do plano individual e para além do tratamento tipográfico, de forma a contemplar a concepção de conhecimento postulada pelos novos estudos de letramento.

Essa re-significação do portfolio constitui um debate muito recente. Dentre as produções, mencionamos o trabalho de Barrett (2001) e seu conceito de portfolio eletrônico $^{50}$ :

My definition of electronic portfolio includes the use of electronic technologies that allow the portfolio developer to collect and organize artifacts in many formats (audio, video, graphics, and text). A standards-based electronic portfolio uses hypertext links to organize the material to connect artifacts to appropriate goals or standards."

\footnotetext{
${ }^{50}$ Do termo original em inglês electronic portfolio (Barrett, 2001).
} 
Do ponto de vista do plano individual, as contribuições do portfolio eletrônico são evidenciadas na medida em que, mantendo sua função formativa, ele alavanca a concepção de conhecimento distribuído de que trata Gee (op.cit.), já que seu formato eletrônico permite a condução de aprendizagens, como projetos e pesquisas, de maneira menos verticalizada. Desse modo, o portfolio eletrônico constitui um instrumento avaliativo público.

Nesse sentido, o portfolio eletrônico e outras modalidades da era digital vêm corroborar a crítica quanto às formas estritamente tipográficas predominantes no cenário educacional ao longo dos séculos. Trata-se da inclusão dos diversos modos de significação no processo avaliativo, com destaque para aquelas utilizadas por meio da Internet. Passamos, pois, de um conceito estático do mundo físico das provas escritas e dos portfolios como sinônimos de coletâneas de trabalhos organizados em pastas, para um conceito digital de blogs, wikis e e-portfolios, ou portfolios eletrônicos (Salles, 2007).

Os blogs e os wikis, por exemplo, funcionam como ferramentas para o trabalho com portfolios eletrônicos, juntamente com editores de texto, de imagens e de vídeo. Os blogs são uma espécie de diário pessoal dos usuários ao passo que wikis constituem softwares colaborativos, cuja formatação e autoria textual é de domínio público, diferentemente de uma página da Internet, de domínio privado. A definição de blog por González (2005: 03) ressalta seu caráter colaborativo e público:

Los blogs son un medio de comunicación colectivo que promueve la creación y consumo de información original y veraz, y que provoca, con mucha eficiencia, la reflexión personal y social sobre los temas de los individuos, de los grupos y de la humanidad.

O mesmo autor (ibidem: 07) entende que os edublogs, os blogs educativos, são excelentes instrumentos para uma avaliação formativa, pelos quais vários aspectos podem ser avaliados, como as formas de redação, de produção de comentários e de análise e argumentação crítica acerca dos temas. Soma-se, ainda, a possibilidade de 
avaliar aspectos performáticos, como o desempenho dos alunos na criação de hipertextos ${ }^{51}$ e o desenvolvimento de estratégias colaborativas nos trabalhos em grupo.

Dentre as contribuições do trabalho com blogs no processo educacional, Fonseca (2006), por sua vez, destaca o interesse da parte dos alunos em aprender tanto a nova metalinguagem da era digital quanto em produzir uma nova linguagem que vai além do formato escrito; no que diz respeito ao seu propósito avaliativo, o autor entende o uso dos diários virtuais como uma forma dinâmica e motivadora para o envolvimento e tomada de decisões dos alunos quanto aos seus próprios desempenhos.

Particularmente, dentre as contribuições do uso de blogs e wikis como ferramentas de trabalhos com portfolios eletrônicos avaliativos para o ensino de línguas, priorizamos a questão do posicionamento dos sujeitos. Isso porque, caracterizados respectivamente como diários pessoais e softwares colaborativos, blogs e wikis constituem estruturas da era digital que imprimem o conceito de "agência" do usuário. Nesse contexto específico, o portfolio eletrônico como instrumento avaliativo passa a ser entendido como fruto de uma construção social para além do plano individual, num processo em que o poder de agência de alunos e professores possibilita a negociação de sentidos e a distribuição de conhecimentos naquela comunidade de prática específica e em outras comunidades afins.

Diante dessas considerações, entendemos que os estudos em avaliação educacional das últimas décadas do século XX contribuíram para uma conceituação mais voltada para seus propósitos, com ênfase para o aspecto formativo, o que possibilitou o desenvolvimento de instrumentos alternativos de avaliação. Do ponto de vista das teorias de letramentos, reconhecemos tais contribuições, ressalvando-se, contudo, sua evidente base psicológica fundadora e as limitações desta frente às transformações tecnológicas de nosso tempo; transformações estas que apontam para uma outra resignificação das categorias que a avaliação da aprendizagem encerra, dentre as quais destacamos o conteúdo, as características e as modalidades.

\footnotetext{
${ }^{51}$ Um hipertexto constitui uma "conexão estabelecida pelos programadores do site, ou de uma página de um site, entre páginas aparentemente não seqüenciais ou não direta ou explicitamente conectadas, sendo essa conexão feita por meio de um link sobre o qual se clica, levando o leitor à nova página escolhida por ele." (OCEMs, 2006: 105)
} 


\section{Considerações finais}

Ao nos depararmos com as últimas páginas dessa pesquisa desenvolvida ao longo de três anos, não resistimos ao desejo de completude e à busca permanente por respostas às nossas 'inquietações pedagógicas', desejo este certamente agravado por estarmos situados nas "considerações finais". Assim é que retomamos as perguntas direcionadoras deste trabalho como forma de olhar para o macro e identificar as respostas que emergiram diante do que foi investigado.

A primeira pergunta de pesquisa propunha caracterizar a avaliação da aprendizagem nas aulas de inglês em algumas comunidades do Ensino Fundamental. Acreditamos que a observação das aulas nos três contextos possibilitou-nos tanto identificar a concepção de avaliação das participantes da pesquisa quanto à própria prática da avaliação da aprendizagem no dia-a-dia escolar de cada uma delas.

Assim, no que se refere às concepções e práticas de avaliação das professoras, concluímos que em boa parte dos contextos elas fizeram ressoar as influências do paradigma da modernidade, cujos problemas mais evidentes foram: (1) a sua significação como mensuração, dada a prioridade com que os aspectos quantitativos eram tratados pelas professoras; (2) a ênfase à avaliação de conteúdos objetivos, estáveis e memorizáveis, uma influência do modelo positivista de ensino; e (3) a utilização de provas escritas como a principal modalidade de avaliação. Naturalmente, outras pesquisas poderiam ter encontrado outros problemas voltados para a questão da avaliação, uma vez que se trata de um tema amplo, com diferentes possibilidades de enfoques. Decidimos, pois, compartilhar os três problemas mais recorrentes ao longo da pesquisa, os quais emergiram sobretudo das concepções e práticas avaliativas de Aida, do Colégio Teorema, e de Sofia, do Colégio Áureo.

Uma concepção de avaliação que pareceu diferenciar perante os preceitos do pensamento moderno também foi identificada, dessa vez no contexto da EMEF. Essa conclusão fundamenta-se na medida em que Beatriz, embora inserida numa visão humanista liberal de ensino, entendia a avaliação como mecanismo de acompanhamento dos alunos para a melhoria de seus aprendizados, transparecendo uma concepção de 
avaliação formativa em seu plano individual. Além da própria narrativa de Beatriz, outras evidências sustentaram a análise, como o uso da auto-avaliação e a dedicação da professora aos registros escritos sobre o aprendizado dos alunos, mesmo diante da ausência de exigências institucionais formais dado o regime de Progressão Continuada, implementado em 1996.

Essa descontinuidade entre a forma de ensinar e a forma de avaliar na prática de Beatriz constitui uma dentre tantas outras identificadas nos três contextos, o que nos levou a elaborar um capítulo que antecedesse as especificidades da avaliação e enfocasse a concepção de língua das professoras bem como suas práticas pedagógicas num sentido mais amplo.

Assim é que nos deparamos com um modelo de ensino estruturalista adotado nas três comunidades observadas, fundamentado por uma concepção de língua como um código lingüístico abstrato, em que os significados encontram-se acabados. Esse modelo caracterizou-se pelo ensino fragmentado e descontextualizado de regras gramaticais num processo que negligencia a importância do contexto de uso da linguagem, reproduzindo nos contextos escolares a falácia da regra (Bourdieu, op.cit.) e o subseqüente tratamento abstrato da língua.

Ao tomarmos uma visão do macro, levando-se em conta concepções de língua, formas de ensinar, concepções de avaliação e formas de avaliar, pudemos identificar muitas descontinuidades e contradições nas vivências escolares. A esse respeito, nossa maior evidência é certamente Sofia e suas interessantes e oscilantes narrativas, reveladoras não apenas de sua concepção amalgamada de língua mas também dos conflitos de ordem institucional, tipicamente postos em contextos de ensino neoliberais. Ressalva-se aqui, contudo, a possibilidade de diferentes leituras quanto ao que vem constituir o 'amalgamado' nesse contexto específico, não nos cabendo assumir uma postura prescritiva diante do que observamos. De qualquer forma, o vaivém das narrativas de Sofia e sua insistência na busca de explicações para as inadequações do ensino dão margem para pensarmos que a professora tem consciência de que seu atual modelo de ensino não lhe apraz, embora não saiba ao certo como modificá-lo. Ou seja, mudar é preciso; resta saber o caminho. Acaso esse não seria o contexto de outros professores em outras realidades? 
No que diz respeito à nossa segunda pergunta de pesquisa, direcionada à concepção de avaliação da aprendizagem de línguas sob a perspectiva dos novos estudos de letramento, acreditamos que esta pôde ser de certa forma contemplada diante das contribuições teóricas de Cope e Kalantzis (op.cit.), Gee (op.cit.) e Lankshear e Knobel (op.cit.) e da identificação de novas modalidades de avaliação que já vêm sendo utilizadas em alguns contextos educacionais (González, op.cit.; Fonseca, op.cit.).

Com isso, não assumimos a tarefa de propor receitas prontas para a avaliação da aprendizagem de língua inglesa segundo as teorias de letramentos, mas arriscamos esboçar algumas possibilidades de práticas nesse escopo, sinalizando algumas modificações quanto ao conteúdo, às características e às modalidades da avaliação.

No que se refere ao conteúdo, propusemos um exercício de inferência segundo o conceito de letramento crítico, compartilhando outras possibilidades de abordagem para algumas das atividades de inglês elaboradas pelas professoras-participantes da pesquisa. Com relação às características da avaliação, entendemos que sob a ótica dos estudos de letramentos a avaliação deva constituir-se distribuída, colaborativa, situada e negociada, corroborando a idéia de conhecimento distribuído, colaborativo e dinâmico sinalizada por Cope e Kalantzis (op.cit.) e Gee (op.cit.) em detrimento da concepção de avaliação do paradigma da modernidade, de caráter individualista, concentrado, estanque, homogêneo e objetivo. Finalmente, pudemos igualmente identificar na literatura novas modalidades de avaliação que nos pareceram condizentes com as teorias de letramentos, dentre as quais o portfolio eletrônico e os edublogs.

A importância com que as teorias de letramentos vêm sendo tratadas sobretudo em âmbito internacional nos leva a pensar a necessidade de expansão de conhecimento sobre o tema em pesquisas acadêmicas brasileiras. Ao compartilhar algumas questões teóricas acerca desses estudos, esperamos ter contribuído nesse processo de troca do conhecimento e convidamos o leitor ao exercício de vislumbrar o ensino da língua inglesa sob uma nova base epistemológica de educação emergente na sociedade contemporânea de forma a corroborar a natureza dinâmica e distributiva do conhecimento, de que tratam as teorias de letramentos. 


\section{Referências bibliográficas}

AFONSO, A. J. Avaliação educacional: regulação e emancipação. São Paulo: Cortez, 2000.

ALMEIDA FILHO, J. C. P. Dimensões comunicativas no ensino de línguas. Campinas, SP: Pontes, 1998.

ÁLVAREZ MÉNDEZ, J. M. Avaliar para conhecer, examinar para excluir. Porto Alegre: Artmed Editora, 2002.

ANDRÉ, M. E. D. A. Etnografia da Prática Escolar. Campinas: Papirus, 2003, $10^{\text {a }}$ ed.

APPLE, M. W. Educação e poder. Porto Alegre: Artes Médicas, 1989.

BAKHTIN, M./VOLOCHINOV, V. N. Marxismo e filosofia da linguagem. Trad. M. Lahud e Y. F. Vieira. São Paulo: Hucitec, 2004. 11 a edição (1ª ed.: 1973)

BALL, S. J. (Comp.) Foucault y la educación - disciplinas y saber. Madrid: Ediciones Morata, 1997. Trad: Pablo Manzano, $3^{\text {a }}$ edição.

BARRETT, H. Electronic Portfolios - A chapter in Educational Technology; An Encyclopedia to be published by ABC-CLIO. 2001. Disponível em http://electronicportfolios.com/portfolios.htlm\#conf. Acesso em 12/04/2007.

BAXTER, A. Evaluating your students. London: Richmond publishing, 1997.

BONNIOL, J-J. e VIAL, M. Modelos de avaliação - textos fundamentais. Porto Alegre: Artmed, 2001.

BOURDIEU, P. A economia das trocas lingüísticas: o que falar quer dizer. São Paulo: Edusp, 1996. 
BROADFOOT, P. Education, assessment and society: a sociological analysis. Buckingham: Open University Press, 1996.

BRUNNER, J. A cultura da educação. Porto Alegre: Artmed, 2001.

BULFINCH, T. O Livro de ouro da mitologia. Rio de Janeiro: Ediouro, 2002. 27 edição.

BURBULES, N. C. \& BERK, R. Critical Thinking and Critical Pedagogy: Relations, Differences, and Limits. In: POPKEWITZ, T. S. \& FENDLER, L. (eds). Critical Theories in Education: Changing Terrains of Knowledge and Politics. Great Britain: Routledge, 1999.

CANDAU, V. M. \& OSWALD, M. L. M. B. Avaliação no Brasil: uma revisão bibliográfica. Cadernos de Pesquisa, São Paulo, n.95, p.25-36, 1995.

CATANI, A.M. \& OLIVEIRA, J. F. A reforma da educação superior no Brasil nos anos 90. In: CATANI, A.M. \& OLIVEIRA, R. P. (orgs). Reformas educacionais em Portugal e no Brasil. Belo Horizonte: Autêntica, 2000.

CHAVES, S. M. A avaliação da aprendizagem no ensino superior: realidade, complexidade e possibilidade. Tese de Doutorado, Faculdade de Educação da Universidade de São Paulo, 2003.

CERVETTI, G., PARDALES, M. J. \& DAMICO, J. S. A tale of differences: comparing the traditions, perspectives and educational goals of critical reading and critical literacy. Reading Online, 2001. Disponível em: http://www.readingonline.org/articles/art index.asp?HREF=/articles/cervetti/index.html

COPE, B. \& KALANTZIS, M. (ed.) Multiliteracies: literacy learning and the design of social futures. London: Routledge, 2000. 
CONTRERAS, J. A autonomia dos professores. São Paulo: Cortez, 2002.

CORDEIRO, J. F. P. Falas do novo, figuras da tradição - O novo e o tradicional na educação brasileira (anos 70 e 80). São Paulo: Ed.Unesp, 2002.

COSTA, N. B. Contribuições do marxismo para uma teoria crítica da linguagem. Rev. D.E.L.T.A., Vol. 16, N. 1, 2000 (27-54)

CUNHA, M. I. Profissionalização docente: contradições e perspectivas. In: VEIGA \& CUNHA (orgs.). Desmistificando a profissionalização do magistério. Campinas: Papirus, p.127-147, 1999.

DALBEN, A. I. L. F. Das avaliações exigidas às avaliações necessárias. In: VILLAS BOAS, B. M. F. (org.) Avaliação: políticas e práticas. Campinas: Papirus, 1991.

ESTEBAN, M. P. S. Investigación cualitativa en educación - fundamentos $e$ tradiciones. Madrid: Ed. McGraw-Hill/Interamericana de Espanã SAU, 2003.

FAVARETTO, C. F. Unidade e Multiplicidade no debate sobre o pós-moderno. In: MARTINELLI, M. L. et. al. (org). O uno e o múltiplo nas relações entre as áreas do saber. São Paulo: Cortez/Educ, 1995.

FERNÁNDEZ ENGUITA, M. La profesión docente y la comunidad escolar: crónica de un desencuentro. Madrid: Ediciones Morata, 1995.

FIDALGO, S. S. A avaliação de Ensino-aprendizagem: ferramenta para a formação de agentes críticos. Dissertação de Mestrado. PUC-SP, 2002

FONSECA, A. A. O uso do diário virtual ( $b \log$ ) como portfólio digital: uma proposta de avaliação. XI SIMPÓSIO DE CIÊNCIAS DA COMUNICAÇÃO NA REGIÃO SUDESTE, Ribeirão Preto, SP, $2006 . \quad$ Disponível em: http://triangulohost.com.br/webfolio/index.html. Acesso em: 09/04/2007. 
FRANCHI, E. P. A insatisfação dos professores: conseqüências para a profissionalização. In:____ (org.). A causa dos professores. São Paulo: Papirus, 1995.

FRANCO, M. L. P. B Pressupostos Epistemológicos da Avaliação Escolar. In: SOUSA, C. P. (org.) Avaliação do rendimento escolar. Campinas: Papirus, 1983, Coleção Magistério, Formação e Trabalho Pedagógico.

FREIRE, P. Pedagogia da autonomia. Rio de Janeiro: Paz e Terra, 2004.

FOUCAULT, M. Vigiar e punir. Petrópolis: Ed. Vozes, 2005. $30^{\mathrm{a}}$ edição

GEE, J. P. New people in new worlds: networks, the new capitalism and schools. In: COPE, B. \& KALANTZIS, M. (ed.) Multiliteracies: literacy learning and the design of social futures. London: Routledge, 2000.

. Situated language and learning - a critique of traditional schooling. United Kingdom: Routledge, 2004.

GENTILI, P. A. A. O discurso da "qualidade" como nova retórica conservadora no campo educacional. In: Gentili, P. A. A. e Silva, T. T. (orgs.). Neoliberalismo: qualidade total e educação. Petrópolis: Vozes, 1999.

GIROUX, H. A. O pós-modernismo e o discurso da crítica educacional. In: SILVA, T. T. (org.) Teoria educacional crítica em tempos pós-modernos. Porto Alegre: Artes Médicas, 1993.

. Os professores como intelectuais: rumo a uma pedagogia crítica da aprendizagem. Daniel Bueno (Trad.) Porto Alegre: Artes Médicas, 1997.

GONZÁLEZ, F. S. Herramientas colaborativas para la enseñanza usando tecnologías web: weblogs, redes sociales, wikis, web 2.0. CONFERÊNCIA NA UNIVERSIDADE DE LEÓN, León, Espanha, outubro de 2005. Disponível em: www.gabinetedeinformatica.net. Acesso em: 10/04/2007. 
HUBERMAN, A, M. Como se realizam as mudanças em educação. São Paulo: Cultrix, 1973.

JAPIASSÚ, H. e MARCONDES, D. Dicionário básico de filosofia. Rio de Janeiro: Jorge Zahar Editor, 1996.

KLEIMAN, A. Avaliando a compreensão: letramento e discursividade nos testes de leitura. In: RIBEIRO, V. M. (org.) Letramento no Brasil: reflexões a partir do INAF 2001. São Paulo: Global, 2004, 2a edição.

LANKSHEAR, C \& KNOBEL, M. New literacies - changing knowledge and classroom learning. UK: Open University Press, 2003.

LUCKESI, C. C. Avaliação da aprendizagem escolar. São Paulo: Editora Cortez, 2003, $15^{\mathrm{a}}$ edição. - Avaliação da aprendizagem na escola - reelaborando conceitos e recriando a prática. Salvador: Malabares, 2005, $2^{\text {a }}$ edição.

LUKE, A. \& de CASTELL, S. Literacy, Society and Schooling. New York: Cambridge University Press, 1989, p. 90 - 91

LUDKE, H. "Um Olhar Crítico sobre o Campo da Avaliação Escolar.” In FREITAS, L.C. (org) Avaliação - Construindo o Campo e a Crítica. Florianópolis: Insular, 2002.

MACHADO, N. J. Educação: projetos e valores. São Paulo: Escrituras, Coleção Transversais, 2002.

MARCELO GARCÍA, C. Formação de professores - para uma mudança educativa. Porto: Porto Editora, Coleção Ciências da Educação século XXI, 1999.

MARCONDES, D. A crise de paradigmas e o surgimento da modernidade. In: BRANDÃO, Z. (org.) A crise dos paradigmas e a educação. São Paulo: Cortez. Coleção Questões de nossa época. Vol. 35, 2002. 
MENEZES DE SOUZA, L. M. Hibridismo e tradução cultural em Bhabha. In: ABDALA JUNIOR, B. (org.) Margens da cultura: mestiçagem, hibridismo e outras misturas. São Paulo: Editorial Boitempo, 2004.

MINISTÉRIO DA EDUCAÇÃO. Secretaria de Educação Básica. Orientações Curriculares para o Ensino Médio - Linguagens, Códigos e suas Tecnologias. Vol 1. Brasília: 2006.

MIZUKAMI, M. G. N. Ensino - as abordagens do processo. São Paulo: Editora Pedagógica e Universitária Ltda, 1986.

MONTE MÓR, W. Memória e Relato Sobre Vitor de Aveyron. ANPED - Revista Brasileira de Educação, São Paulo, v. 3, p. 107 - 111, Se/Out/Nov/Dez 1996.

. Reading Dogville in Brazil: Image, Language and Critical Literacy. Language and Intercultural Communication. Inglaterra, Vol.6, N. 2, p.124-135, 2006

MORIN, E. A cabeça bem-feita: repensar a reforma, reformar o pensamento. Rio de Janeiro: Bertrand Brasil, 2005

NASCIMENTO, C. A. R. Monismo e pluralismo epistemológico. In: MARTINELLI, M. L. et. al. (org). O uno e o múltiplo nas relações entre as áreas do saber. São Paulo: Cortez/Educ, 1995.

OLIVEIRA, R. P. Reformas educativas no Brasil na década de 90. In: CATANI, A.M. \& OLIVEIRA, R. P. (orgs). Reformas educacionais em Portugal e no Brasil. Belo Horizonte: Autêntica, 2000.

OLIVEIRA, D. A. \& FONSECA, M. O Banco Mundial e as políticas de formação docente: a centralidade da educação básica. In: HIDALGO, A. M. \& SILVA, H. L. F. (orgs.) Educação e Estado: as mudanças nos sistemas de ensino do Brasil e Paraná na década de 90. Londrina: Editora da UEL, 2001. 
PARIS, S. G. e AYRES, L. R. Becoming reflective students and teachers (with portfolios and authentic assessment). Washington D. C., American Psychological Association, 1994.

PENNYCOOK, A. The cultural politics of English as an international language. Harlow: Longman, 1994.

PERRENOUD, P. Avaliação: Da excelência à Regulação das Aprendizagens. Porto Alegre: Artmed, 1999.

PIMENTA, S. G. Professor reflexivo: construindo uma crítica. In: PIMENTA E GHEDIN (org.) Professor reflexivo no Brasil: gênese e crítica do conceito. São Paulo: Cortez, $3^{\mathrm{a}}$ edição, 2005.

PRABHU, N. S. Second language pedagogy. Oxford: Oxford University Press, 1987.

RICHARDS, J. C. and RODGERS, T. S. Approaches and methods in language teaching. Cambrigde: Cambridge University Press, 1996. Tenth printing.

Approaches and methods in language teaching. Cambrigde: Cambridge University Press, 2001, Second Edition.

ROLIM, A. C. O. A cultura de avaliar de professoras de língua estrangeira (inglês) no contexto da escola pública. Dissertação de Mestrado. IEL/UNICAMP, Campinas, 1998.

ROSATI, M. I. dos S. A ética na historicidade humana. In: SANTOS, C. R. (org.) \& FERREIRA, M. C. I. (coord.). Avaliação educacional: um olhar reflexivo sobre a sua prática. São Paulo: Avercamp, 2005.

SACRISTÁN, J. G e PÉREZ GÓMEZ, A. I. Compreender e transformar o ensino. Porto Alegre: Artmed, 2000, $4^{\mathrm{a}}$ edição

SALLES, M. Blog pessoal da autora. Disponível em: http://www.miriamsalles.info/wp/. Acesso em: 09/04/2007 
SAUSSURE, F. de. Curso de lingüística geral. Trad. do francês de Antônio Chelini, José Paulo Paes e Izidoro Blikstein. São Paulo: Cultrix. 1999. 1ª ed. original: 1916.

SAVIANI, D. Tendências e correntes da educação brasileira - capítulo. In: MENDES,

D. T. (coord.). Filosofia da educação brasileira. Rio de Janeiro: Civilização Brasileira, 1991, $4^{\mathrm{a}}$ edição.

. Pedagogia Histórico-Crítica: primeiras aproximações. Campinas:

Autores Associados, 1996.

SCARAMUCCI, M. V. R. Avaliação: mecanismo propulsor de mudanças no ensino/aprendizagem de língua estrangeira. In: Contexturas - Ensino Crítico de Língua Inglesa. São José do Rio Preto: APLIESP, 1998/1999, nº 4.

SEDYCIAS, J. O que é inglês Instrumental? Novembro, 2002. Disponível em: http://home.yawl.com.br/hp/sedycias/instrument.htm\#top. Acesso em 26/09/2006.

SEVERINO, A. J. Educação, Ideologia e Contra-ideologia. São Paulo: EPU, 1986.

SHEPARD, L. The Role of Assessment in a Learning Culture. In: Educational Researcher, 2000, vol. 29, no. 7, pp. 1-14.

SMITH, F. A metaphor for literacy: creating worlds or shunting information. In OLSON, R., TORRANCE, N. e HILDYARD, A (ed.). Literacy, language and learning - the nature and consequences of reading and writing. London: Cambridge University Press, 1993.

SOARES, M. Alfabetização e letramento têm o mesmo significado? Rev. Pátio, ano IX, n.34, p.50-52, mai/jul 2005. . Letramento e escolarização. In: RIBEIRO, V. M. (org.) Letramento no Brasil: reflexões a partir do INAF 2001. São Paulo: Global, 2004, $2^{\mathrm{a}}$ edição. 
SOUSA, R. M. R. Q. Professores de inglês da escola pública: investigações sobre suas identidades numa rede de conflitos. Dissertação de Mestrado, FFLCH/USP, São Paulo, 2006.

SOUSA, S. M. Z. L. Avaliação da aprendizagem nas pesquisas no Brasil de 1930 a 1980. Revista Cadernos de Pesquisa, São Paulo, n. 94, 1995, p.43-49.

. Escola e empresa: iniciativas de parceria no Estado de São Paulo. In:

FERREIRA, N.S.C. \& AGUIAR, M. A. (orgs.) Gestão da educação: impasses, perspectivas e compromissos. São Paulo: Cortez, 2000.

SOUSA, S. Z. L. e OLIVEIRA, R. P. Políticas de avaliação da educação e quase mercado no Brasil. Rev. Educação e Sociedade, Campinas, no. 84, vol. 24, Set /2003

THORNDIKE, E. L. \& GATES, A. I. Elementary Principles of Education. New York: The Macmillan Company, 1931.

TORRES, C.A. Teoria crítica e sociologia politica da educação. Trad. Maria José do Amaral Ferreira. São Paulo: Cortez, 2003.

TOSI, M. R. Didática Geral: um olhar para o futuro. Campinas, SP: Alínea, 2003.

TRIPP, D. Critical theory and educational research. Issues In Educational Research. Volume 2(1), 1992, 13-23.

TYLER, R. W. Princípios básicos de currículo e ensino. Porto Alegre: Editora Globo, 1975. $2^{\mathrm{a}}$ edição.

VASCONCELLOS, C. S. Avaliação da aprendizagem: práticas de mudança por uma práxis transformadora. São Paulo: Libertad, 2003. $5^{\text {a }}$ edição.

VIANNA, H. M. Avaliação: considerações teóricas e posicionamentos. Rev.Estudos em Avaliação Educacional, n.16, p.99-102, jul/dez 1997. 
Avaliação educacional: uma perspectiva histórica. Rev.Estudos em Avaliação Educacional, n.12, jul/dez 1995.

VIEIRA, V. M. O. Portfolio: uma proposta de avaliação como reconstrução do processo de aprendizagem. Rev. Psicologia Escolar e Educacional. Campinas, SP, n. 2, v.6, dez./2002

VILLAS-BOAS, B. M. F. O portfolio no curso de pedagogia: ampliando o diálogo entre professor e aluno. Rev. Educação e Sociedade. Campinas, SP, n. 90, v. 26, jan./abr. 2005

WATSON-GEGEO, K. A. Ethnography in ESL: defining the essentials. In: Tesol Quarterly, Vol. 22, n. 4, p. 575-592, Dec/1988.

WOODS, D. Teacher Cognition in Language Teaching - beliefs, decision-making and classroom practice. Great Britain: Cambridge University Press, 1996.

WORTHEN, B. R.; SANDERS, J. R. e FITZPATRICK, J. L. Avaliação de programas: concepções e práticas. São Paulo: Editora Gente, 2004. 


\section{Anexo 1}

VOCABULÁRIO:

4) $H$ ow $=$ como

1) $y_{0}=$ vore

3) LiKE = goota de, gosta da, goitody

4) $5 c H 001=2 \Delta c 0$ ra

5) WHAT $=0$ gut, gual

6) $5=i s=e^{\prime}$, 2stá

7) THE $=\theta, a, \infty, a s$

8) DIFFERENCE = difenemea

9) BETWEEN = enthe

AO) HERE = aqui

M) $A O D=e$

12) THERE = lá

13) $S A Y=D I 2, F A L A$

14) $w H E N=$ ausunds

15) $M E E=$ encentro

16) $A=u m, u m A$

17) $6405 T=$ Dantasma

18) $\mathrm{CAN}=$ pode

19) BREAK = GMbrar

00) with $=$ com

21) ONLY ONE= apenas uma

22) $W O{ }^{2} D=$ palawa

2.3) How mAny = guountos

24) $\operatorname{sides}=\operatorname{Rads}$

25) HOUSE = casa

26) $H A V E=\operatorname{tam}$

27) ONE - Lem

32) $M A G N E T=2 M A$

29) TO THE OHER = pan ooto

30) $\mathrm{tet}$ is mine = é man.
31) but = mas

32) $m y=$ meus, minhas; mer,

minla

33) FRIENDS = amige?

34) USE IT $=$ usam - no

35) MORE THAN mE = mais do ave ex

36) WHAT is IT? = S que ? ?

37) CALL = demomina dhame

38) liFE STORY = 2atónd on vid

39) OF A = de um

40) $C A R=$ carro

4.) montis = meson

42) DAYS = dias

43) LETTER = letra

44) NAME = nome

45) SiLENe $=$ Sitencis

46) $T w 0=$ dees, deas

47) inside $=$ dentwo

48) OUTSiDE $=$ fora

4a) $\operatorname{CLOSED}=$ Dechada, bechodr

50 you $A R E=$ VOCA

51) VERY $=$ midts

52) ATTRACTIVE = abraenta

53) NOT A WORD = nenherma.

palaura.

54) $305 T=$ Aomente

55) RUN $=$ corre

56) 10 ESCAPE = 20campon.

67) ALL = todas, tedes

58) PEOPLE = penoas

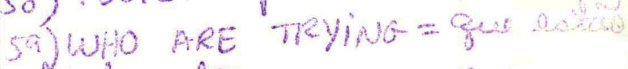

60) To kibl it = matá 2

$610 \mathrm{~F}$ THEM = Q Q

62) $W H Y=$ Por que

63) TIME = tempo 
Relacione as colunas:

(1) How do you like school? () The letter "T".

(2) What's the difference between ( My name. here and there?

(3) Why does time fly?

(4) What do you say when you meet a ghost?

(5) What can you break with only one word?

(6) How many sides does a house have?

(7) What does one magnet say to the other?

(8) It is mine, but my friends use it more than me. What

( ) Silence.

( Two: inside and outside

( Closed.

( ) you are very attractive

( An auto-biography

( Not a word you just run.

() to escape all the people who are trying to kill it.

( ) All of them

(9) What do you call the life story of a car?

(10) How many months have 28 days? 
English activity - PAgE 2-

NAME

TRADUCÁ̄O DAS PERGUNTAS

(1)

(2)

(3)

(4)

(5)

(6)

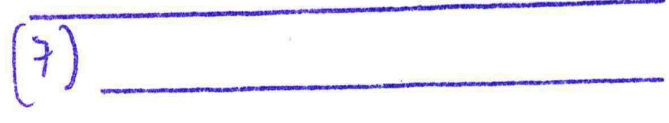

(8)

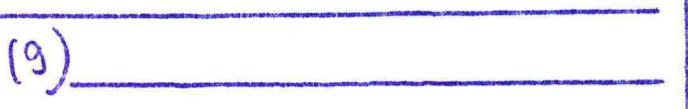

TRADUCÁA DAS RESPOSTAS

()

( )

()

()

()

()

()

()

(10)

( )

( ) 
Anexo 2

\section{ENGLISH ACTIVITY - DATE \\ NAME

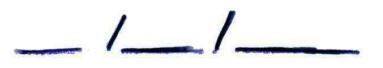 \\ NUMBER 6 th \\ MY PET (Meu Animal de Estimação)}

\begin{tabular}{|c|c|}
\hline mmm & $\begin{array}{l}\text { My name is Bob. } \\
\text { I have a dog. } \\
\text { Its name is Toby. } \\
\text { It eats bones and drinks } \\
\text { water. } \\
\text { It has a small house. }\end{array}$ \\
\hline $\begin{array}{l}\text { vocabulário: } \\
\text { 1) My = meu, minha, meus, minhas } \\
\text { 2) name = nome } \\
\text { 3) is = e', está } \\
\text { 4) I =en } \\
\text { 5) have = tenho, possurs } \\
\text { 6) } 2=u m \text {, uma } \\
\text { 7) dog = cachorrs } \\
\text { 8) Its = seu, dele } \\
\text { 9) It = ele }\end{array}$ & $\begin{array}{l}\text { 10) eats = come } \\
\text { 11) bones = ossos } \\
\text { 12) and = e } \\
\text { 13) drinks = bebe } \\
\text { 14) water = a'gua } \\
\text { 15) has = tem, porsui } \\
\text { 16) small = pequena } \\
\text { 17) house = casa }\end{array}$ \\
\hline
\end{tabular}

Responda em inglés, de acondo com o-taxto:

1) Does Bob have a dog?

2) What does Toby drink?

3) Does Toby have a big house or a smale house?

4) Does Toby lat fish? 
Trabalho individual de ingles para entregar no dia 06/12/2005 (3aff) em folla de i papel almazo ou pulfite ou fichário ou caderno. Fazer uma capa simples. Veja o modelo abaixo:

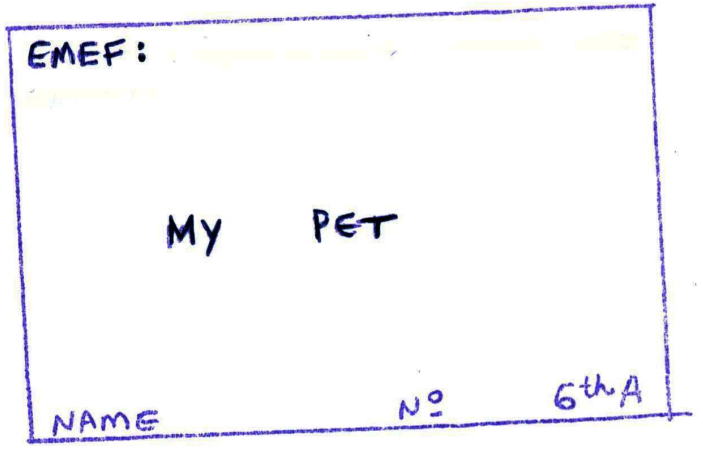

Responda as perguntas em ingless utilizando os esquemas estudados em classe:

1) Do you LikE PETS? (Vorê goata de animais de estimação?) 3) WHAT KIND OF PET DO YOU. HAVE? (Que tipo de animal de estimagāo voé tem?) 4) WAT is iTS NAME? (Qual e'o nome dele?)

5) How OLD is iT? (Quantos anos ale tem?)

6) WHAT DOES IT EAT? ( $Q$ que de come?)

7) DOES IT IRINK MILK OR WATER? (Gle bebe leite ou água? )

8) WHAT COLOR is IT? (De que cor ele e'?)

9) DOES it have A SPECIAL House? ( Gle tem uma casa especial? )

10) DOES it STAY in YOUR HOUSE OR in YOUR YARD? (Elifica dentro de sua casa ou no seu quintal?) 


\section{Anexo 3}

VOCABULÁRIO = NATAL

b) Christmas = Natal

2) CHRISTMAS TREE = funvere de Natal.

3) CHRISTMAS CARD = cartás de natal

4) $H A P P Y=$ MERRY = feliz

5) NEW YEAR = Qno Novo

6) NEW year's eVe = Véspera de Ono Nowo 7)CHRISTMAS' EVE = Vésera de Natal

8) GIFTS = PRESENTS = presentes

9) SANTA CLAUS = FATHER CHRISTMAS = Papai Noel 10) SLEIGH = trenó

14) REINDEER = roma

12) CANDLE = vela

13) $T 0$ Y $5=$ brinquedos

14) STOCKING = meia

15) $S T A R=$ athelaw

16) $B E L L=\sin \theta$ 17) CANDY CANE = bengalinal
doce
18) CHRISTMAS CAROLS = cangoes de Matal

19) SEASON'S GREETINGS

- Boar Festas

20) NATIVITY SCENE=

Presépio

21) EVE=Vispera, dia anterior

22) $C A R D=\operatorname{cart}^{2} a^{2}$

23) TREE = ónore

24) $C A R O L=$ cancáo, misica natalina, tamberm e'um nome ferminino = Carolina .
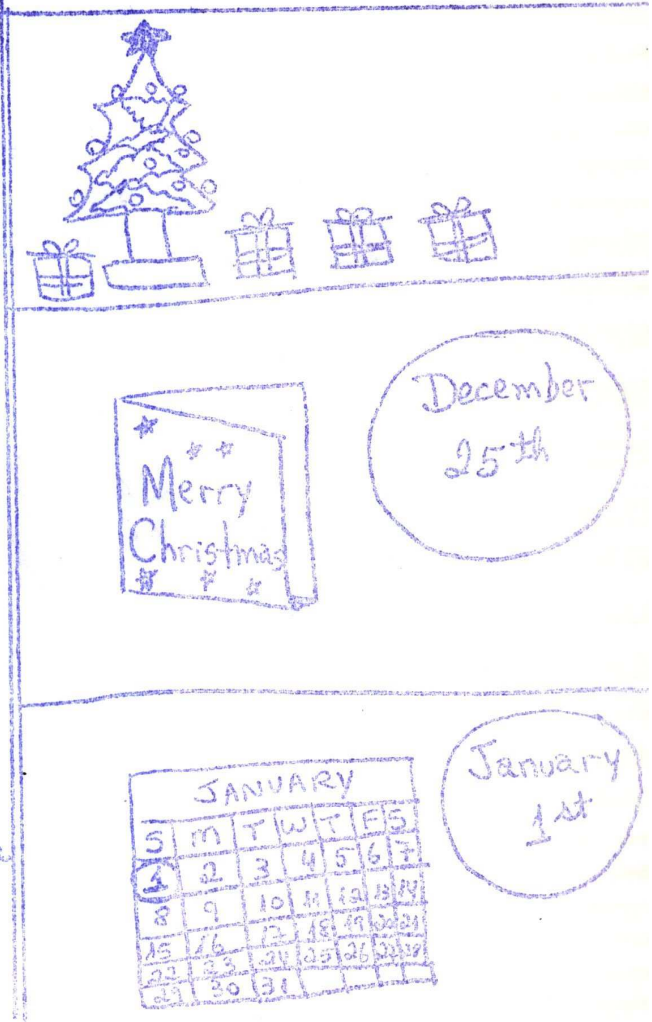
Resolva a palama cruzada (CROSSWORD) em ingles. Desculana nas casas enn destaque qual palara refenente as natal que aparecerá:

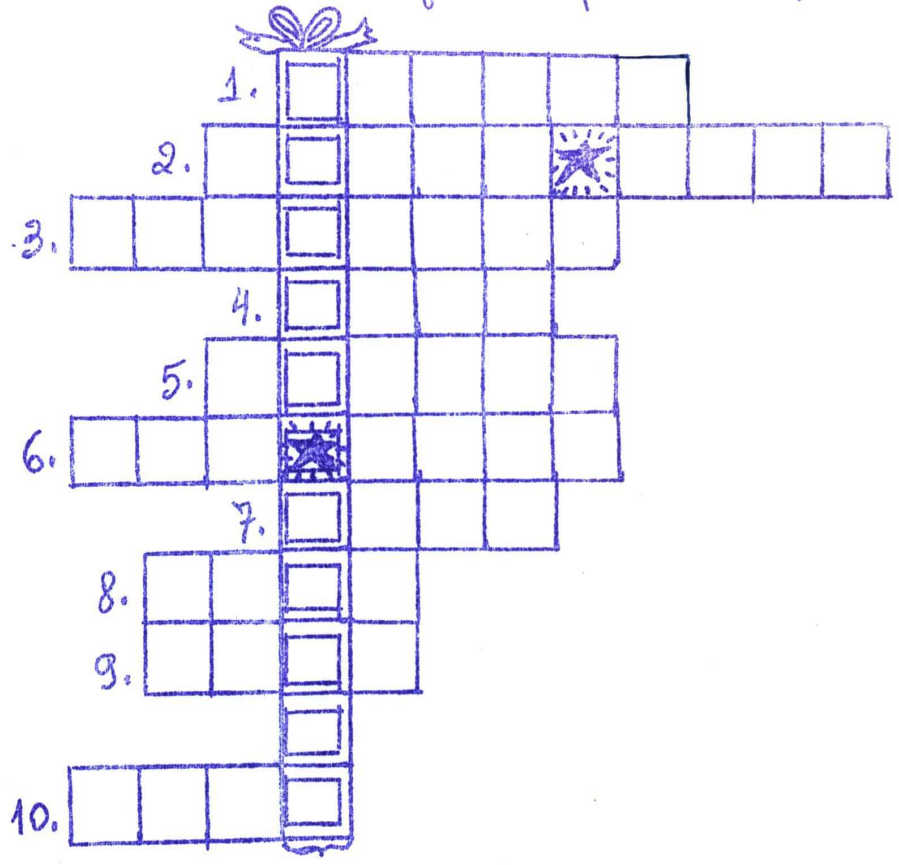

\begin{tabular}{|c|c|c|c|c|}
\hline 1. TRENO & 2. BengalinaA & DCE & & RENA \\
\hline 4. A'RVORE & 5. VELA & 6. ANO & Novo & 7. CARTAO \\
\hline 8. $\sin 0$ & 9. ESTRELA & \multicolumn{3}{|c|}{ 10. BRINQVEDOS } \\
\hline
\end{tabular}

\footnotetext{
Q palaura em inglés que aparreceu em destaque portuguesa significa

, que em língua
} 


\section{Anexo 4}

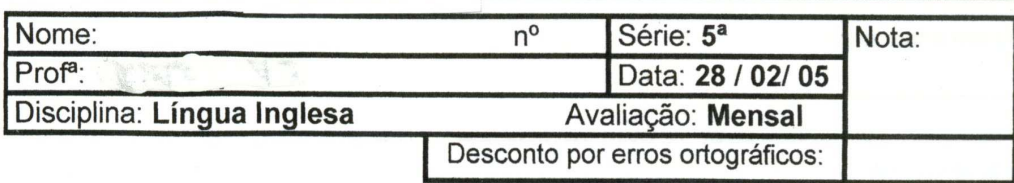

Orientações para fazer uma boa avaliação

- A avaliação tem duração de 50 minutos e deverá ser feita à caneta;

- É proibido o uso de corretivo:

- As questões de múltipla escolha não poderão ser rasuradas em hipótese alguma. Caso isso ocorra as mesmas serão anuladas:

- Não é permitido nenhum tipo de consulta no decorrer da avaliação;

- Escreva de forma legível. O não entendimento das respostas poderá prejudicar sua nota;

- Seja cauteloso. Pense antes de escrever para evitar que sua avaliação fique cheia de rabiscos;

- A cada 2 erros ortográficos será descontado 0,1 de sua nota.

1. Escreva um diálogo: (1.0)

You: Hello

You: What's

Your friend: My

You: Where

Your friend:

2. Complete com what, who or where. (1.0)

a-) is this? This is Pelé.

b-) ___ are you from? I'm from São Paulo.

c-) ___ is your name? My name is Renato.

d-) are this girls? They are my fiends.

e-) is this? This is my book.

3. Complete com o verbo To Be. ( $\mathrm{am}$, is, ou are ) (1.0)

a-) from Brazil.

b-) You ___ from England.

c-) We__ from United States.

d-) She __a girl.

e-) Peter__ a student.

4. Passe as frases abaixo para as formas negativa e interrogativa. (1.0)

a-) We are friends.

N

b-) Carol is my neighbor.

N. 
c-) You are a teacher.

$\mathrm{N}$

d-) He is at school.

N

I

5. Reescreva as frases substituindo os nomes pelos pronomes I, YOU, HE, SHE, IT, WE, THEY.(1.0)

a-) Paul is a boy.

b-) Jim and John are friends.

c-) The dog is black and white.

d-) Carol is a girl.

e-) The bird is yellow.

6. Complete as frases com as nacionalidades corretas. (1.0)

a-) I'm from Brazil. I'm

b-) He is from Germany. He's

c-) She is from the U.S.A. She's

d-) You are from Canada. You are

e-) We are from Italy. We're

7. Escreva o significado das expressões abaixo, em português:( 1.0 )

a-) Can you repeat, please?

b-) Speak more slowly, please?

c-) Can I have some water, please?

d-) Can I go to the toilet, please?

8. Escreva o nome de cada um dos continentes de acordo com o mapa abaixo ( 2.0 )

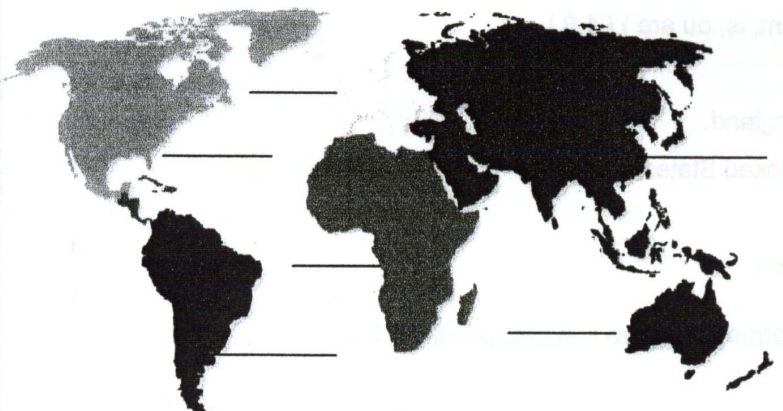

3-

9. Complete as frases abaixo: (1.0)

a-) Brazil is located in

b-) Canada is located in

c-) Japan is located in

d-) Kangaroos are native to 
Anexo 5

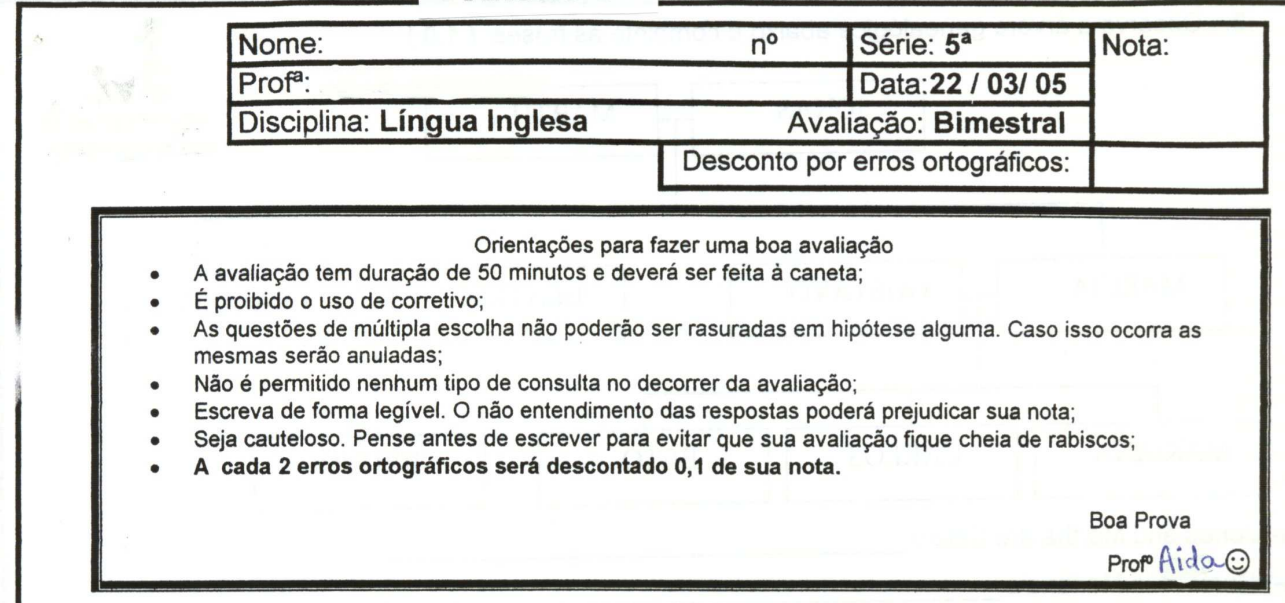

1. Faça frases negativas e depois corrija-as utilizando as palavras entre parênteses Siga o exemplo. (1.0)

Ex: Ronaldinho is a tennis player. ( soccer player)

Ronaldinho is not a tennis player. He is a soccer player.

a-) Rita Lee is American. ( Brazilian )

b-) Antonio Banderas is from Mexico. ( Spain )

c-) My favorite sport is tennis. ( football )

d-) Fernando is Beto's uncle. ( father )

2. Relacione as perguntas com as respostas. $(1,0)$

(a) Where's Beto?

(b) What's your brother's name?

(c) Who are these people?

(d) Who's this girl in the picture?

(e) Where's Paul from?

(f) How do spell your last name?

(g) Are you all right?

They are my school friends.

$D-O-U-G-L-A-S$.

) yes, I'm OK.

) Flávio

) She's my friend.

) He's from Canada

) He's at school. 
3. Observe a árvore genealógica abaixo e complete as frases. $(1,0)$

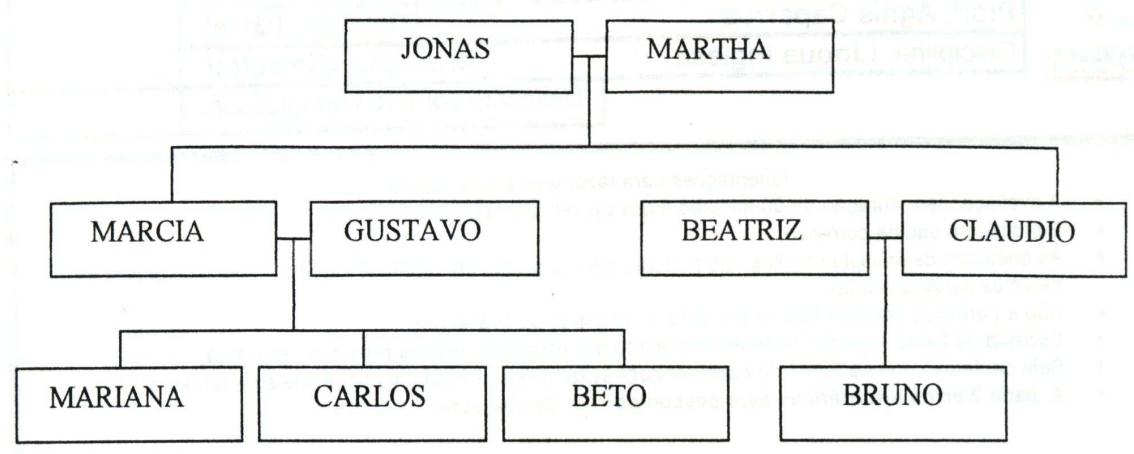

a-) Jonas and Martha are Beto's

b-) Gustavo is Mariana's

c-) Claudio is Carlos'

d-) Carlos and Beto are Mariana's

e-) Beto is Bruno's

$\mathrm{f}-)$ Beatriz is Bruno's

4. Passe as frases abaixo para a forma interrogativa. (1.0)

a-) Mariana's father is forty years old.

b-) Carlos is Beto's brother.

c-) They are in Rio de Janeiro.

d-) Your pets are cute.

5. Escreva $I$, you, he, she, we ou they nos espaços para completar as frases. $(1,0)$

a-) Hello! ___ am Carlos. ___ am Beto's big brother.

b-) This is Mariana. ___ is my sister.

c-) These are our pets. ___ are cute.

d-) These are my grandparents. ___ are very nice.

6. Complete as frases com HIS ou HER. (1.0)

a-) Here is Fábio with computer.

b-) This is Mariana with friend.

c-) This is Fernando with ___ son.

d-) Here is Marcia with husband. 
7. Complete a seqüência: (1.0)

a-) two, four,

b-) three, six

c-) four, eight,

d-) five, ten,

8. Escreva em inglês, o nome de quatro planetas que fazem parte do nosso sistema solar. (1.0)

a)

b-)

c-)

d-)

9. Encontre o nome de quatro planetas: (2.0)

\begin{tabular}{|l|l|l|l|l|l|l|l|l|l|}
\hline A & U & D & G & N & P & B & V & J & N \\
\hline R & B & P & O & E & V & E & N & U & S \\
\hline O & M & H & S & P & E & R & T & P & G \\
\hline M & E & A & R & T & H & N & O & I & T \\
\hline V & R & X & L & U & A & H & J & T & S \\
\hline T & C & P & N & N & S & E & C & E & V \\
\hline S & U & L & K & E & D & U & I & R & A \\
\hline I & R & U & C & F & F & R & W & Q & D \\
\hline J & Y & T & Z & I & M & A & R & S & R \\
\hline T & N & O & W & G & K & N & Y & D & L \\
\hline N & E & Y & S & A & T & U & R & N & Q \\
\hline L & A & T & Q & J & U & S & E & F & Y \\
\hline
\end{tabular}


Anexo 6

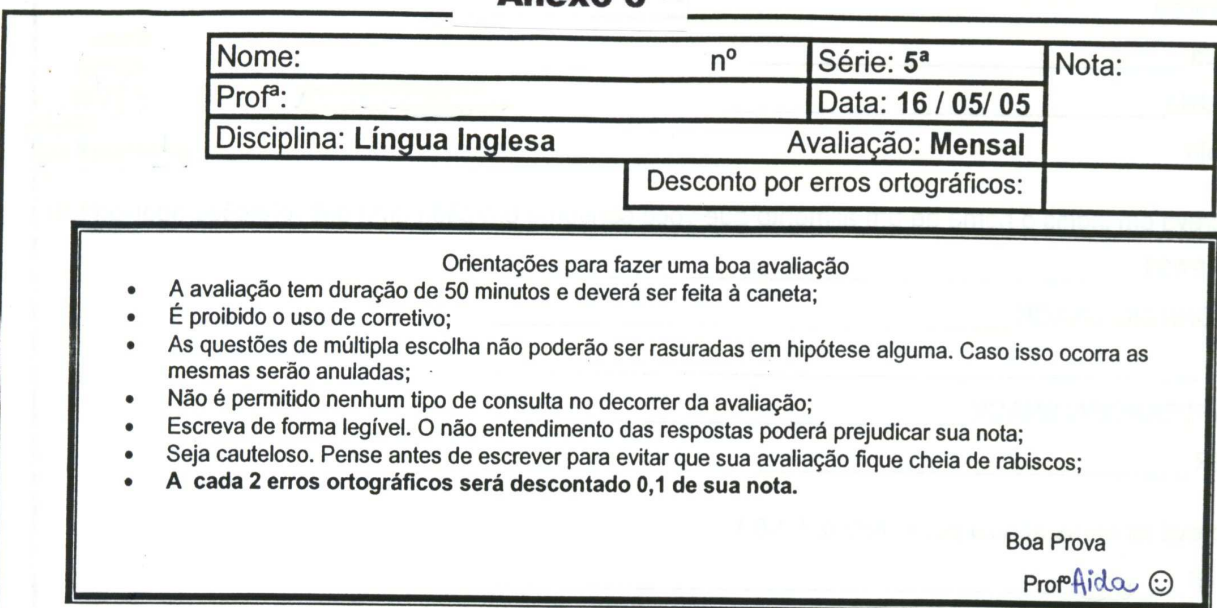

1- Escreva os números abaixo por extenso: ( 1.0 )

a-) 56 -

b-) 80 -

c-) $22-$

d-)11-

2- Passe as frases abaixo para o português ( 1.0 )

a-) Anything to drink?

b-) I'm sorry.

c-) Excuse me

d-) Can I help you?

e-) How much is that?

3-) Escreva os preços abaixo: ( 1.0 )

CN\$ 41.20-

US\$ 39.30

£ 68

$R \$ 51,00$

4-) Coloque A, An ou X. (1.0)

a-) sandwich

b-) ___ orange.

c-) pens.

d-) _ envelope.

e-)_tomato

5-) Escreva em inglês o nome dos objetos abaixo: ( 1.0 )

a-) clips de papel 


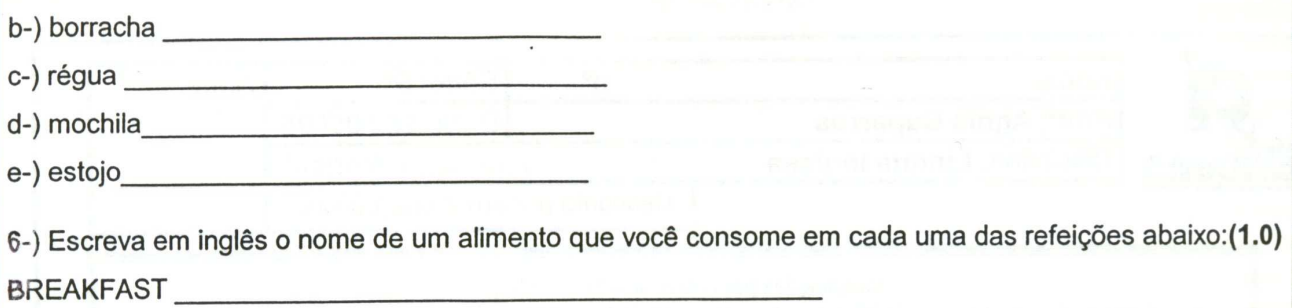

6-) Escreva em inglês o nome de um alimento que você consome em cada uma das refeições abaixo:(1.0) BREAKFAST

MID-MORNING SNACK

LUNCH

MID- AFTERNOON SNACK

DINNER

7-) Escreva as horas abaixo por extenso: ( 1.0 )

a-) $2: 45$

b-) $3: 15$

c-) $9: 25$

d-) $10: 50$

e-) $11: 00$

8-) Complete os espaços abaixo com as preposições AT ou ON: ( 1.0 )

a-)

b-) _ 4 o'clock

c-) _ November $25^{\text {th }}$

d-) __ _ lunch time

e-) __ Christmas Day

9-) Traduza as palavras abaixo: ( 1.0 )

a-) mushrooms

b-) green pepper

$c-)$ sausage

d-) lettuce

e-) carrots

10-) Desenhe uma pirâmide alimentar e escreva em cada um dos espaços o nome dos " 6 " grupos de alimentos: (1.0) 
COLÉGIO

Escola de Educação Infantil, Ensino Fundamental e Médio

Site:

\section{Avaliação Bimestral de Inglês - $2^{\circ}$ Bimestre - 2005}

São Paulo, de de 2005 .

Nome:

$5^{\mathrm{a}}$ série do Ensino Fundamental II - manhã

Ass. do(a) Professor(a):

Ass. do(a) Responsável:

1. Esta Avaliação contém questões. Num total de

pontos.

2. Resolva e responda as questões a lápis, etapa por etapa, nos espaços indicados e dê as RESPOSTAS À

\section{CANETA AZUL OU PRETA.}

3. Durante a avaliação, procure expressar sua aprendizagem de forma clara, organizada e completa.

4. Não peça esclarecimento das questões, pois sua interpretação faz parte da avaliação.

5. O uso de corretivo invalidará a questão.

7. Não é permitido o empréstimo de material.

TENHA UM BOM DESEMPENHO!!!

Fred King is tall and handsome. He isn't fat and he isn't thin. He's got short fair hair and green eyes. His age is a secret.

Fred is a famous American actor. He's very rich. He's got a beautiful new car. It's a Porsche. His house is large and comfortable. It is locates in a rich section of Los Angeles.

Fred isn't married. He's got a girlfriend. Her name is Vanessa. She's a pretty top model. She's very tall and thin. She's from America, too. Fred loves animals. He's got 3 pets: 2 dogs and a bird. The dog's names are Buffy and Lordy. Melody is the bird's name.

"Talk to the Star" is a radio program. A famous person is on the line and the listeners have to guess who he/she is. Today, Fred King is on the line.

1- Here are Fred's answers. Write the interviewer's questions:

a-

Yes, I am tall.

b-

I've got short fair hair.

No, I've got green eyes.

d-

Oh! This is a secret. 
2- Read the text and complete the spaces. Use my, she, her, he, his, they, their, we or our:

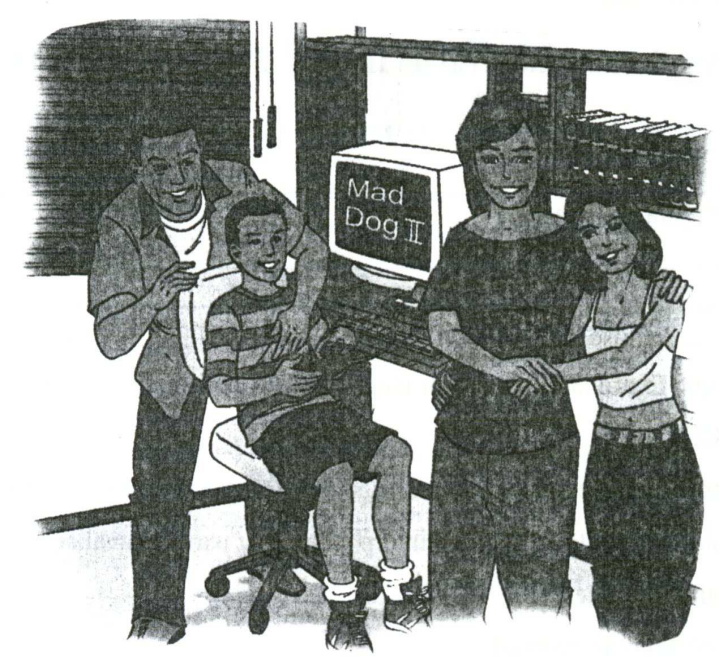

This is a picture of my aunt and her family. and is a dentist. The man on the right is name is Paulo. is an engineer. forty years old. ve got two children. daughter's name's Cristina and

Marcos. Cristina is 14 's tall and

hair and green eyes. Marcos is 12 and age. cousins and I are good friends. is Mad Dog II. are crazy about computer games. name is Clara husband. are both son's name's s got long black is quite tall for favorite game

3- Complete the dialogue. Choose from the expressions in the box:

$$
\text { Something to drink? Can I help you? }
$$

A small packet How much is that? Anything else? 
At the school cafeteria

A-

B- Yes, a cheeseburguer and a coke, please.

A.

B- A bar of chocolate, please.

B-

A- That's $£ 2.16$, please.

B- Here you are. Thank you.

4- Make true sentences. Use am, am not, is, isn't, are, aren't, have got, haven't got, has got or hasn't got:

a- 1

14 years old.

b- Beto a brother and a sister.

c- Beto's sister brown eyes.

d- We a sports car.

e- Paul and Alan from Brazil.

$f-1$ wo sisters. g- Gustavo Borges ___ tall and he

h- Beto Canadian. short black hair.

i- The students at school at the moment.

5- Complete the sentences with on or $\boldsymbol{a t}$ :

a- My tennis classes are

b- The football game is Wednesday.

c- Diogo's birthday is five minutes to ten.

$\mathrm{d}$ - There are no classes September $5^{\text {th }}$.

e- There is a good film on TV Saturdays and Sundays.

f- When is The Calling's show? It's midnight today. 8 o'clock p.m. Thursday.

\section{6- Put in there is/there isn't/ is there?/ there are/ there aren't/ are there?:}

a- Look! a photograph of our neighbor in the newspaper!

b- Excuse me, a good restaurant near here?

c- __ five people in my family: my parents, two sisters and me.

d- We can't take photographs.

e- How many students a film in the camera.

$\mathrm{f}$ - Brasília is a very modern town. in this classroom?

g- Where can we sit? There are only tables in this room. many old buildings.

ha bus from the city center to the airport?

i- a a train at 10.30. It's very comfortable. $\mathrm{j}-{ }_{1}$ a good program on TV at this time? Yes, a good film on channel 45. chairs! 
7- Complete the text using $\boldsymbol{a}$, an when necessary:

We have comfortable. It has colorful for my taste. Each wall has wall, yellow wall and ice living room, but there is different color. There is two purple walls. There are

old house, but it is problem: it's too paintings on the walls, too. We have to paint the living room again urgently! The other rooms are OK.

8- Look at the picture. Then write right (R) or wrong $(\mathrm{W})$ :

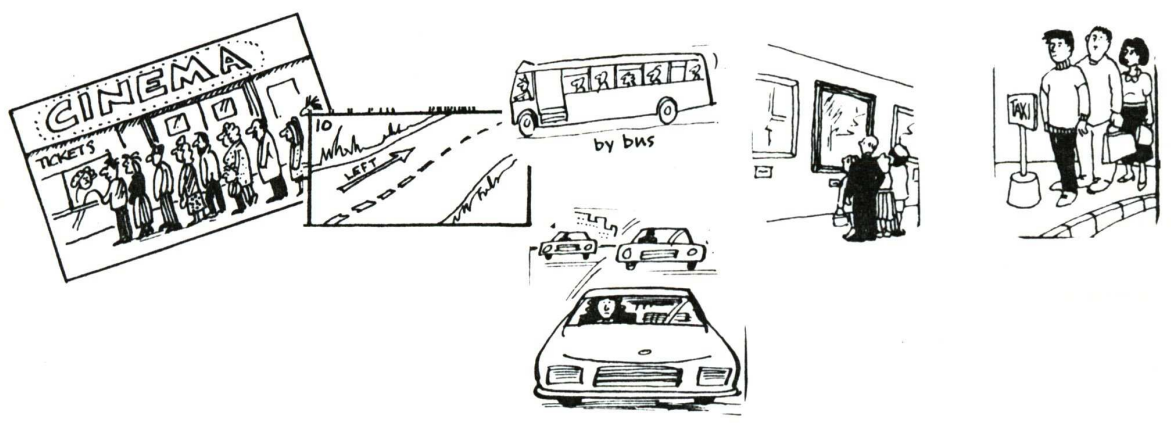

a- There are three cars in the picture. $(\quad$ )

b- There is a bus on the street. ( )

c- There are five peoples on the sidewalks. ( )

$\mathrm{d}$ - There is a taxi in the picture. $($ )

e- There is a cinema in the picture. ( )

f- There are three children crossing the street. ( )

Have a nice test!

Teacher Jofia 


\begin{tabular}{|c|}
\hline COLÉGIO \\
Escola de Educação Infantil, Ensino Fundamental e Médio \\
Site:
\end{tabular}

Prova de Inglês- $4^{\circ}$ Bimestre - 2005

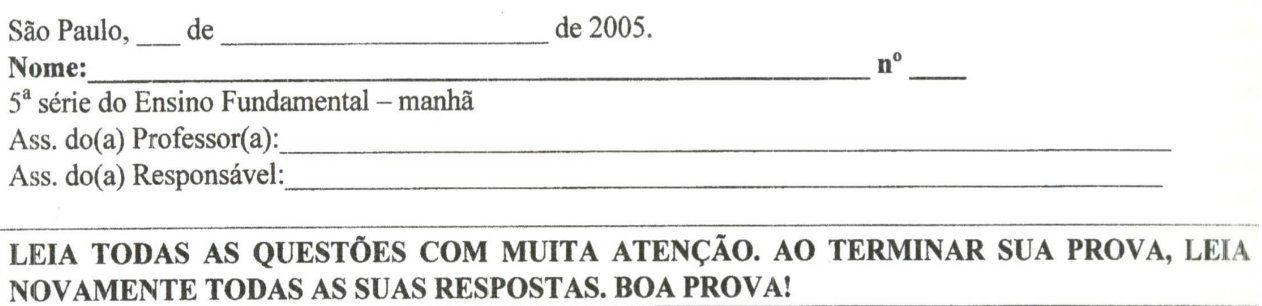

1- Text:

\section{Teen Lives.}

Sharon Muller is a typical teenager - blue jeans, t- shirt, and tennis shoes. She likes music dancing, movies and parties. But one thing about Sharon Muller is different. Read her story.

"I'm 14 years old, but I'm not in school. The last time I was in school was in fourth grade (I was 9!). Now my school is my home and my mother is my teacher."

A typical day in Sharon's life is like this: she has breakfast at eight o'clock. Twenty minutes later she goes to the backyard for exercises (and to give breakfast to her pets: 2 rabbits and 4 birds!). At nine o'clock it's "book" work - math, science and computer science. Then she has lunch at twelve- thirty. In the afternoon, starting at 2, she studies English and foreign languages. Her mother is from Germany and speaks German, English and Spanish, so Sharon studies three languages! At four o'clock there's a break for half an hour and then Sharon plays the guitar for forty- five minutes.

Sharon's boyfriend, Steve, is in high school in the city. In the evening he and Sharon are in the city center they go to the movies or to the skating rink. Sharon doesn't get home late. Her week days are very busy, so she goes to bed at $10 \mathrm{o}$ 'clock from Monday to Friday. On weekends she can stay out till midnight. Sharon likes "homeschool" and she thinks her mother is a fanstastic teacher.

Davy, K. \& Harmer, J. Touchdown 1-Workbook. London: Longman, 1995. p 57- 58.

Vocabulary: Teen, teenager - adolescente

Was - estive

Late - tarde

Busy - atarefado (s), cheio (s) de atividades

Read the text and answer these questions. Write complete sentences:

a- How old is Sharon?

b- Where is Sharon's mother form? 
d- Where do Steve and sharon go in the evening?

2- Complete Sharon's schedule:

\begin{tabular}{|l|l|}
\hline \multicolumn{1}{|c|}{ Time } & \multicolumn{1}{c|}{ Event } \\
\hline-8 a.m. & - Breakfast \\
\hline- & - \\
\hline- & - \\
$-\overline{-}$ & - \\
- Evening & - \\
-10 p.m. (on week days) & - \\
\hline
\end{tabular}

3- Complete the sentences with the verbs in the parentheses. Use the Present Simple Tense in the correct form:

My name (be) Doug Winston. I (live) in New York with my parents. We father both (live, not) in a house. Our home (work). My mother (have, not) an office. She (be) a writer. She mother and my magazines. She (have) a store in the shopping mall. He (write) stories for

(be) a businessman. $\mathrm{He}$ (sell) watches.

4- Match:

1- Who's your friend?

2- What's her name?

3- What's his name?

4- Is it your calculator?

5 - Is it her pencil?

6- Is that his book?

7 - Is she your sister?

8- Is he your father?

9- Who's that woman?

$10-$ Who's this boy?

( ) She is my teacher.

( ) Yes, he is

( ) My friend is Jennifer.

( ) He's my boyfriend.

( ) Her name is Cindy.

( ) No, it's her calculator.

( ) His name is Peter.

( ) Yes, she is.

( ) No, that's not his book

( ) Yes, it is.

\section{5- Supply Where, Who or What.}
a-
is your name?
b- is that boy?
c-
is your room number?
d- is that?
e- __ is your English book, Gary?
$\mathrm{f}-\_$color is your pencil case?
g- __ is the old chair?
h- $\quad$ is your mom? 


\section{Anexo 9}

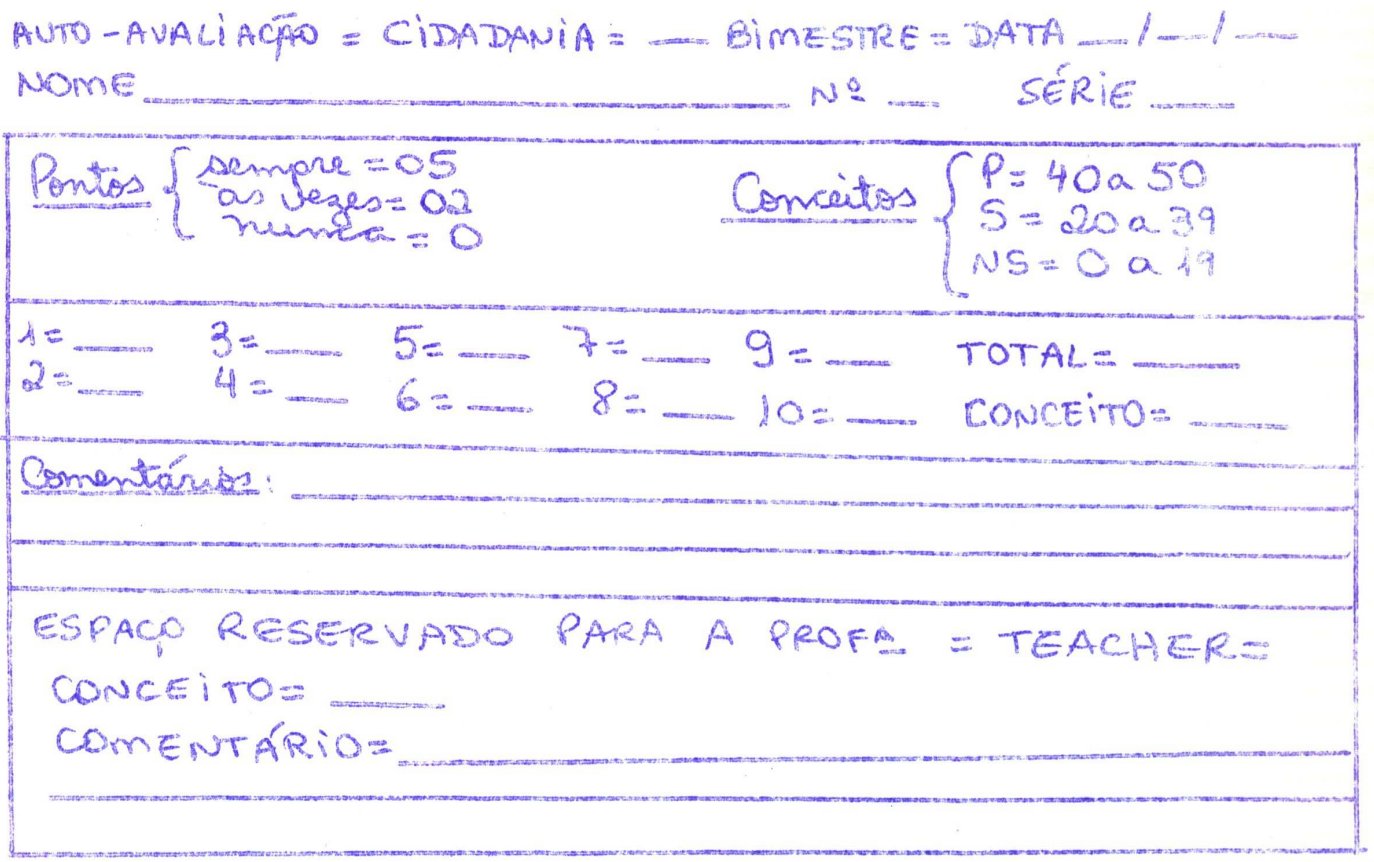


AWOAVALIACR DE TUGLS - ROTEIRO BIMESTRAL

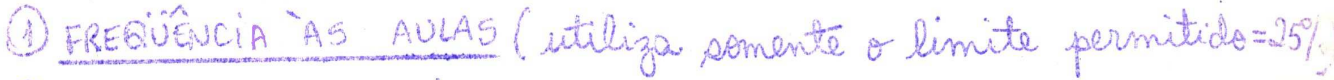

(2) CADERno (cotém as antacoés básicas: resumos, tabelas, excemplos, accicicios, textos, dílogos, oto.)

(3) PERMPNENCIA NA SALA dE AULA (evia soir da clase para beber água, ir as bambirs, telafonar, eto.)

(4) RESPEITO AOS COLEAS (enta discusbio, brincadivas de mau-goto, apdidos, to.)

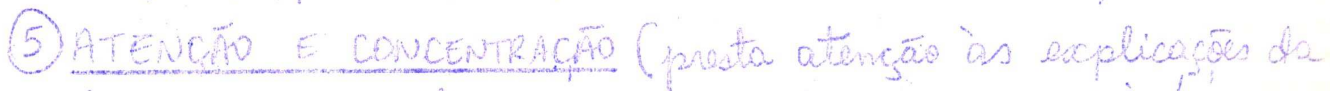
preposera e concentra-se pora realinar on excercícos as atividads.

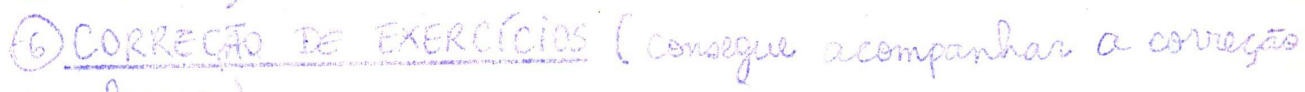
wa lowar.

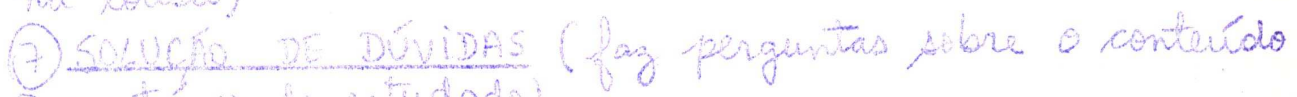

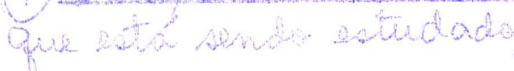

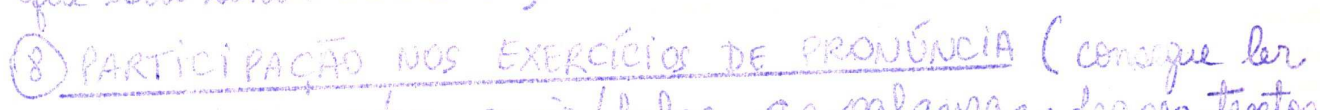

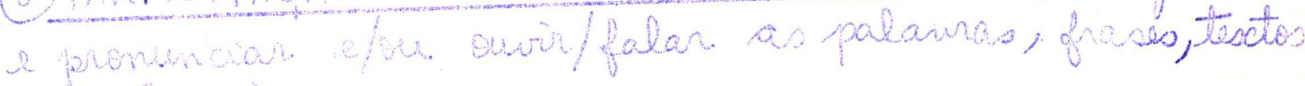
dialogor.

Q REALZAC DE ATIVIDADES MinEOGRAFADAS (ponogie concliu Qu Widader minegrafodos no prazo determinads pela plotesena.)

(10) HIDATS EN DUPAS OU GRUPOS Rag a wa pante e

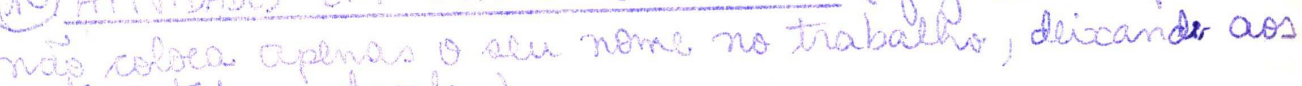
outros tota a tanela.)

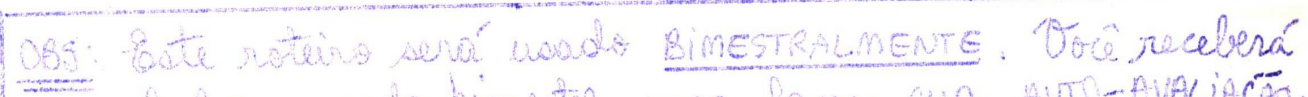

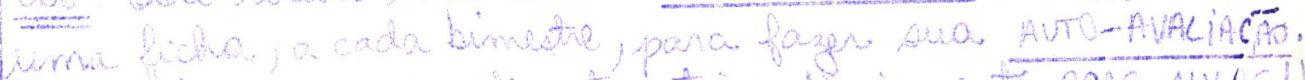

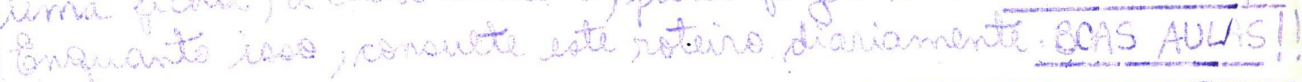




\section{Apêndices}

\section{Apêndice 1}

\section{SIMBOLOGIA UTILIZADA NAS TRANSCRIÇÕES}

( ) Incompreensão de palavras ou segmentos
/ Truncamento

MAIÚSCULA Entonação enfática

:: $\quad$ Prolongamento de vogal ou consoante

$\ldots \quad$ Qualquer pausa

[ Superposição de vozes

(...) Retomada da fala

(( )) Falas / Comentários do observador

A Aluno não-identificado pelo observador

A1 Cada aluno identificado e reconhecido pelo observador

A1, A3 Dois alunos reconhecidos falam ao mesmo tempo

As Vários alunos falam ao mesmo tempo

A', A" Alunos diferentes não-identificados falam ao mesmo tempo 


\section{Apêndice 2}

\section{Entrevista com a professora Aida}

DIA: 14 de abril de 2005

HORA: $10 \mathrm{~h} 30$

LOCAL: Colégio Teorema (ensino privado)

((Na verdade eu vim conversar com você sobre a escola, o que você acha, há quanto tempo você está aqui...))

Aida: Eu me formei... olha eu nem me recordo quanto tempo faz, mas já faz bastante tempo... É... pois é... não parece mais eu acho que... olha eu já to trabalhando com língua inglesa há:: oito anos...então onze anos como professora e oito anos com inglês.

((por que? Antes você dava aula de Português?))

Aida: Dava aula primeira a quarta:: dava aula pros pequenininhos... aí até... quando eu terminei a faculdade que eu comecei mesmo... a:: trabalhar com a língua inglesa. Aqui na escola... são três... é o terceiro ano que eu estou aqui.

((a escola é nova, não é?))

Aida: O colégio tem doze anos, né? Só que é assim... agora que... acho que há uns... é... há pouco tempo que tem o colegial, que não tinha, né? Então a escola agora que cresceu assim efetivamente... o número de alunos tal porque antes eram menos alunos por sala... tinha uma quinta série, uma sexta...

((a escola tem quantos alunos, você sabe?))

Aida: Olha... ao todo são quinhentos e quinze, mais... assim se eu te falar exatamente... eu sei que ao todo são quinhentos e quinze porque é o número que alunos que eu tenho.

((e aí só tem de primeira...))

Aida: É... e mais a pré-escola, porque [são..mais a pré-escola além dos quinhentos e quinze...] é.. é...

((e aí você dá aulas de inglês de primeira série até...))

Aida: [até o colegial]. O terceiro colegial nós não temos esse ano, né?

((ainda não formou?))

Aida: Não... até iria formar, mais no ano passado a classe do segundo ano era muito pequena... e um e outro repetiu aí já não dava pra montar uma classe de três, quatro alunos né?

((tá. Aí você pegou o inglês em praticamente todas as turmas))

Aida: Isso. Isso é... esse é o segundo ano que eu estou fazendo isso... o ano que eu entrei aqui eu só dava aula de quinta a oitava porque não tinha ensino médio... o ano passado teve ensino médio e aí eu peguei de primeira a quarta também que eu saí de um outro colégio... peguei todas as turmas aqui e esse ano também.

((e eu vi que o material que vocês estão usando é uma apostila, não é?))

Aida: Isso.

((Como é que é? É... vocês sempre usaram essa apostila?)) 
Aida: Então... de primeira a quarta série não. De primeira a quarta série são os livros...acho que você não chegou a ver, né? E de quinta a oitava é uma apostila pro ano inteiro... Apostila do Homo Sapiens... e esse é o terceiro ano que está sendo...terceiro? É, é o terceiro ano... quando eu entrei aqui:: eu entrei em maio, era o primeiro ano deles com a Apostila Homo Sapiens. Eu já trabalho com a Apostila Homo Sapiens há mais tempo, há cinco anos porque eu já vim de outra escola eu conheço o material. E colegial...

((tá, então é uma apostila bem adotada por aí?))

Aida: É...é.

((e o que que você acha? Você gosta?))

Aida: (É porque quando nós vamos fazer...) Porque normalmente pelo menos uma vez... a cada seis meses, né, tem uma reunião do Sistema Homo Sapiens e aí eles convocam todas as escolas... então vem escolas de todas as regiões pra ta fazendo... Santa Catarina... vem de outros lugares de longe.

((mas é uma reunião por mês pra cada, pra várias, vários professores?))

Aida: É. A cada seis meses tem uma reunião. Aí eles marcam pra todas as escolas que usam o método, né, a apostila deles, e:: aí depois lá é dividido por área... aí cada professor vai pra sua área, [primeira a quarta...]

((que que eles fazem?))

Aida: Então, eles falam [sobre] o material, né, o que eles pretendem, aí é mais uma troca de informações mesmo, que esse.. é...uma turma, vai, uma escola aprende legal, em cima da proposta deles... troca de informações mesmo.

((e aí a avaliação tem que ser baseada na apostila? Eles também sugerem a avaliação?))

Aida: Não... Até tem. Eles mandam...até tem. Eles mandam por...né, a cada bimestre um:: um roteirozinho, que você pode ou não usar. Eu geralmente não uso o roteiro deles. Eu faço a prova em cima do conteúdo que eu dei, em cima dos exercícios da própria apostila, mas eu é que elaboro minha prova... eles até mandam como sugestão... né? Mas às vezes eu acho que fica meio fora da realidade dos alunos porque você acaba tendo que adequar o que você ensina à realidade daqueles alunos (...) Cê vê a diferença mesmo você vê... o pessoal da quinta "A"... a quinta "B" tem OUTRO tipo de comportamento diante do, né do conteúdo, então eles vão mais rápido tem uma agilidade diferente da outra turma.

((e aí a prova é diferente?))

Aida: Não. Aí eu adequo fazendo uma prova no meio termo. Coloco uns exercícios um pouco mais puxados, assim é meio que dividido em três etapas né: o basiquinho, o mais fácil, aí o intermediário e um pouco mais difícil... porque mesmo na quinta "A" eu tenho alunos que têm outro tipo de comportamento assim de evolução eles são mais rápidos do que outros... então aí eu tento ficar no meio termo, dou uma puxadinha e:: eu dou uma facilitadinha... justamente porque a gente tem a questão da recuperação a cada bimestre, então os alunos que não conseguem mesmo assim, eles têm mais uma oportunidade de estar fazendo as provas novamente.

((Então, quando você fala prova, como que é o seu sistema? É uma prova bimestral?))

Aida: Então...

((aquela provinha que eu vi, lembra que você me passou duas provas?))

Aida: eu vou te mostrar aqui ((Aida enquanto me mostra os instrumentos avaliativos)) Isso aqui são avaliações contínuas... não tem um número exato de avaliações que você pode dar durante o bimestre

((tá... você escolhe a quantidade e o modo como você faz?)) 
Aida: É... exatamente.

((aí geralmente o que que você faz? Você marca com eles?))

Aida: às vezes sim... às vezes eu mando pra casa outras vezes eu dou na aula, então terminou um conteúdo... ó, agora vocês vão fazer esse, esse e esse exercício na folhinha que eu tenho uma folha específica timbrada da escola e aí... ó vocês têm quinze minutos pra fazer... outras vezes leva para casa e vai fazer em casa pra poder testar em todas as circunstâncias... porque às vezes ele levam pra casa o pai ajuda:: a mãe ajuda:: e acaba tendo um bom rendimento, você faz aqui não tem...né? Então assim pra ver como é que tá realmente às vezes você vai vendo os tópicos que você pega, que você acha que eles sentiram mais dificuldade ou... pra avaliar realmente como é que foi aquele conteúdo, se foi feito, avaliado ou não, o que que você vai pegar mais pesado ou não (...) Aí depois disso nós temos a prova mensal... eu te dei uma cópia da prova mensal...

((tá. Então é uma prova no mês?))

Aida: Isso. Aí depois você continua né? Tem intervalos, você vai colocando avaliação contínua, você vai mesclando.

$(([$ cada professor $]))$

Aida: é...por exemplo Português normalmente tem dez, quinze dependendo porque eles tem mais aulas., eu como só tenho duas aulas, então eu dou cinco, quatro, depende da turma dá pra fazer mais ou não

Aida: Aí depois disso tudo... depois da prova bimestral a gente tira uma média de avaliações contínuas..

((tá... como é que é? Vamos supor, você tem cinco avaliações...))

Aida: Isso, então você soma todas as notas e divide por cinco... dá avaliação contínua, aí tem uma média... aí soma com a mensal, mais bimestral vezes dois e aí divide por quatro.

((aqui a gente tem a média do?))

Aida: média do bimestre. Aí os alunos que tiveram menos do que sete pontos fazem a recuperação porque a média da escola é sete. Então todos esses alunos, ó seis... seis e meio ((Aida, ao falar, mostra-me a lista com nomes e notas de As)) (...) eles fazem a prova de recuperação... aí na prova de recuperação a média de contínua permanece... ela fica... aí é dado um trabalho de recuperação... que você acompanhou que eu estava fazendo com eles, mostrando como é que fazia, explicando novamente e esse trabalho de recuperação... ele substitui a nota mensal (...) aí é feita uma outra provinha que substitui a nota bimestral... aí novamente é feito o mesmo processo, que é peso dois, pra tirar uma média de recuperação (...) aí é comparado, por exemplo: se ele tinha seis e meio na média antes da recuperação e ficou com seis na recuperação, a média final dele é a maior, a gente compara entre as duas e aí fica a maior média.

((tá. E na recuperação eu vi que você passou um roteiro para os alunos?))

Aida: Isso. Exatamente.

((como uma tarefa? Mas não tem aulas de recuperação...))

Aida: então.. assim... o roteiro é dado antes... pra quem tem mais que duas aulas aí é mais fácil porque entrega o roteiro, aí pede pra eles fazerem, dá uma aula em cima do roteiro e depois vai corrigir. Como eu já dei as duas aulas, eu dou o roteiro antes, eles têm que fazer em casa, vir com o roteiro pronto pra gente só corrigir.

((isso em horário de aula mesmo, né? Eu percebi... e os outros alunos, onde é que eles estavam?))

Aida: Então, eles ficaram fazen/foi feito todo um esquema com a professora de educação física... porque há dois anos não tinha isso, ficavam todos na sala...aí ficava aquela confusão no ano passado nós 
decidimos fazer um teste e dar o roteiro pra que todos fizessem... e aí pra quem fazia recuperação o roteiro servia pra estudar, e pra quem não fizesse recuperação ficava com uma nota de avaliação contínua pro próximo bimestre... só que o pessoal não levou a sério, né? Porque eles falavam "ah, já passei::" então eles ficavam/ aí esse ano decidimos fazer/ o professor William combinou com ela e aí ela fez uma gincana e aí esse alunos, os alunos que ficaram em menos de três matérias eles podiam ficar brincando, jogando... os alunos com Mais de três matérias tinham que ficar na sala, por isso que você percebeu, tinha uns alunos lá no fundo da sala que eles não podiam descer e o tempo todo eu ficava, né, faz o teu roteiro de geografia por exemplo... que é uma matéria que ele ficou, vai fazer o seu trabalho de não sei o quê.. aí você percebeu também que alguns alunos saíram da sala e foram até a sala que eu estava, por exemplo, ficou em inglês, português, geografia... nesse intervalo como eles não podem descer, não podiam descer, eles poderiam optar em que matérias eles queriam ficar... então eles iam atrás da professora de inglês, geografia, de história, eles poderiam ficar ali, só que é claro, né? Uma coisinha ou outra, igual hoje o menino "Professora que que é isso?" Dá pra tirar dúvida mas não dá pra ficar explicando porque ele teria na aula dele a oportunidade de tirar dúvida, naquele momento a aula era da quinta série. (...) então por isso que você viu a maior movimentação aqui, tinha aluno trocando de sala, tinha aluno aqui embaixo... mas embora pareça que foi aquela confusão assim de aluno andando, mas ficou muito melhor...

((da avaliação contínua, você geralmente dá então exercício ou provinha ou trabalho?))

Aida: é, por exemplo nós trabalhamos árvore genealógica... então uma avaliação contínua que eu dei foi pedir que eles fizessem a árvore genealógica da família deles e em cima da árvore deles fizessem as frases usando genitivo, e o que eles ficaram vendo na apostila, né...o grau de parentesco, então eu passei uma série de grau de parentesco e eles tinham que, em cima da árvore genealógica deles, fazerem lá dez frases sobre aquele assunto... foi um tipo de avaliação contínua... outras vezes eu pego a própria, o próprio exercício da apostila... com a quinta série é um pouquinho diferente, normalmente eu peço coisas mais simples de eles fazerem e tal... pros maiores já dá pra fazer diferente, eu faço uma interpretação de texto, por exemplo, lemos um texto, fizemos ali a discussão, a tradução... então aí em cima disso tem um questionário lá então "vocês vão fazer agora no final da aula em quinze minutos vocês vão ter que responder"... porque já/né? fizemos todas as etapas do texto, fica fácil de conseguir fazer, então dependendo da turma eu faço a avaliação contínua de um jeito, com a quinta série acaba sendo mais simples...são trabalhinhos de colagem mesmo, por exemplo "procure embalagens com nomes em inglês" e aí eles têm que procurar, colar, escrever o significado...

\section{((tá... agora tudo isso vai pros pais depois, a prova mensal...))}

Aida: entrego pro aluno as contínuas, as mensais são entregues pros alunos... as bimestrais a gente entrega na reunião... pros alunos que os pais não vieram à reunião então aí a gente entrega a prova pro aluno mesmo... e nesse dia que vão as provas tudo nós temos uma pasta que não tenho aqui nenhuma, se você quiser eu pego pra te mostrar, quer que eu pegue? De ocorrências... nessas ocorrências tudo acaba sendo marcado: se ele trouxe o livro, se ele não trouxe o livro, se a avaliação contínua dele foi abaixo da média, se a prova mensal foi abaixo da média, porque se de repente ele não entregar isso pros pais na ocorrência que vai quinzenalmente os pais vão ter um controle de que essa prova foi entregue e qual é a posição dele, da criança em relação às atividades que estão sendo feitas aqui.

((agora você avalia participação?))

Aida: Não.

((o colégio não coloca isso como regra))

Aida: Não. Nota pra tirar ponto positivo, ponto negativo? Não... não

((não tem? participação, se fez tarefa...))

Aida: Não, no livro de ocorrência gente só marca se fez o texto, se trouxe, se não trouxe, mas isso não é contado como nota, não.

((e o colégio tem uma regra pra todos os professores? Quem faz as provas? Quem elabora?)) 
Aida: Os professores. Aí nós fazemos as provas, entregamos... aí a Maira, que é a coordenadora ela dá uma olhada... né? Ela olha a parte estética, né? De repente tem... tá faltando uma letra... um número porque às vezes a gente olhando... depois que a gente faz, a gente olha, olha, e... é... às vezes passa... então ela dá uma olhadinha também.

((e o que que você acha disso? Tem prova contínua, mensal, bimestral... qual é a tua opinião sobre isso?))

Aida:Então, é um sistema que dá certo... né? embora muitas vezes a gente tem aqui mesclar muito essas avaliações contínuas mesmo porque muitas vezes não reflete o aproveitamento do aluno... porque por exemplo... se ele levou pra casa... a avaliação e alguém ajudou... ele vai ter um bom aproveitamento... se eu acabei de dar a matéria e der uma contínua ali no final da aula...o aproveitamento dele também vai ser bom... se eu deixo vai... duas semanas e dou a matéria... aí já é outra coisa... sem avisar né? porque eu posso fazer isso tudo sem avisar... e justamente pra ver se ele memorizou ou não memorizou... então assim dá certo porque se você faz... se você souber mesclar bem você vai conseguir identificar se teu aluno conseguindo memorizar ou não, se alguém tá ajudando ou não, se foi uma questão que tava ali na cabeça no momento... agora em relação a corrigir realmente... dá um trabalhão... porque eu por exemplo que tenho TODOS os alunos da escola né? chega a ter três mil e poucas provas, e provas de uma forma geral, a contínua, mensal, bimestral é ... por bimestre... então assim é o tempo todo corrigindo, fazendo...

((e dos alunos de recuperação, você já teve algum caso de aluno que ficou em recuperação no primeiro bimestre e depois no segundo... o que que você faz nesse caso? O colégio tem alguma solução pra esse aluno?))

Aida: É... na verdade...assim... cada professor é que tem que/o colégio não fala "ah você TEM QUE”, não toma nenhuma posição em relação a isso... claro a gente conversa muito, aí liga pros pais, avisa qual a situação, NESSE sentido o colégio interfere... agora em termos de aproveitamento aí o professor que decide tem professor como eu às vezes eu pego se eu percebo que a defasagem tá sendo muito grande então aí eu vou fazendo exercícios extras pra que ele faça em casa... NEM SEMPRE por isso que eu nem prometo porque às vezes dependendo da demanda de trabalho que eu tenho em casa não dá pra ta seguindo exatamente da maneira que eu gostaria né mas eu procuro fazer o que dá, né? Ás vezes eu pego até os exercícios das próprias provas, coloco de uma outra maneira, entrego e falo "olha você vai fazer, vai me entregar" aí eu dou uma corrigidinha e mando de volta pra eles pra fazer/dar um suporte né? mas algumas vezes não dá pra fazer... aí no final do ano quando eles têm a última oportunidade depois de fazerem recuperação ainda tem mais uma oportunidade que é chamada de exame final aí no exame final ele não tem aula... só marca um dia e aí é a matéria do ano inteiro... que aí ele tem que fazer... só que em termos de nota, também, depois da somatória toda nós dividimos pelo número de bimestre, quatro bimestres, e aí fica sobrando/o que falta pra dez... então por exemplo ele ficou com...cinco.. aí tem que tirar cinco... normalmente não ficam com cinco aí você tem que ver quanto que falta pra nota que ele precisaria tirar...e aí tem que tirar três, dois geralmente os alunos passam só aqueles alunos que realmente vieram com MUITA defasagem é que no exame final não conseguem ou aqueles que ficam em várias matérias aí não dá pra tirar.

((e aí ele reprova?))

Aida: Ele reprova. Claro que o peso do inglês é menor do que em outras matérias. Se por exemplo ficar só no inglês ele não reprova, bom apesar de que hoje também eh... até em termos de legislação uma matéria só não pode ta reprovando... aqui na escola três matérias reprova aí o inglês entra... mas se for SÓ o inglês, por exemplo, não reprovaria ... mas o inglês aqui tem peso sim.

((Tá. E sobre reuniões que o colégio faz, com diretora, coordenadora tem treinamento, reunião, semana pedagógica, planejamento pedagógico no começo do ano...))

Aida: Tem.

((e depois agora no meio do ano vai ter mais algum?))

Aida: Então, a gente faz assim, no começo do ano a gente faz um cronograma...

((vocês chegam a discutir avaliação no planejamento pedagógico ou não?)) 
Aida: Sim. O que os professores/até em termos dessas ocorrências a gente mesmo foi pedindo porque a gente viu necessidade. Esse aqui é da quarta série mas deixa eu ver aqui se eu acho o que da quinta ((Aida mostra cronograma))... então no começo do ano a gente já faz um cronograma de tudo o que a gente vai ta trabalhando, como serão dadas as avaliações contínuas... claro que às vezes fura mas né? a gente procura já montar no cronograma quando que vai ser a prova mensal pra conseguir né e aí a gente discute essas questões, o que será dado, quantas avaliações contínuas... aí eles estipulam mais ou menos né? "Olha, a professora de português tem que procurar dar até no mínimo dez"... se não der pro professor dar tudo bem, não tem importância então pra mim são cinco, mas muitas vezes, cê vê, na quinta série eu dei quatro... mas essas questões todas são discutidas no começo do ano... aí a cada bimestre... antes da reunião de pais um pouquinho antes da prova bimestral geralmente...nós nos reunimos novamente... e aí nós discutimos a situação DOS ALUNOS... "olha tal aluno ta preocupando porque ele não tá entregando isso, não tá entregando aquilo" pra deixar a escola a par do que está acontecendo... aí depois dessa reunião de pais, geralmente é antes da reunião da prova bimestral que nós temos uma reunião com eles... ou extraordinariamente quando acontece alguma coisa ou uma sala está preocupando demais aí a gente vem, o William marca, a gente vem um dia pra ta discutindo isso daí.

((Vocês têm por matéria os objetivos, o que ensinar, no geral ou a parte de inglês por exemplo... eles aprendem listening? Fala? .... A apostila.. o enfoque do curso seria?))

Aida: Tem. É então... eles entregam junto com a apostila um CD...só que o CD até a oportunidade que eu vivo/eu falo pra eles "ouçam o CD em casa" só que eles vêm pra escola e dizem "não consegui porque o CD é muito rápido" né? e eles não estão acostumados, eles vieram de uma realidade diferente né? ...e às vezes eu acho que fura um pouco essa questão do Homo Sapiens nesse sentido... porque eles não têm o material de primeira a quarta aí chega na quinta série com um monte de coisas, textos várias coisas.... aí as crianças da quinta série acabam tendo mais dificuldade e aí eu é que vou colocando às vezes "Oh, hoje nós vamos fazer atividade com CD" ou eu mesma vou ler porque eu sei que eles vão entender melhor porque eu vou fazendo as pausas e tudo... então mas a proposta é efetivamente é GRAMATICAL, não é muito de pronúncia, né? É [parte de conversação], não trabalho com isso não... mesmo porque são muitos alunos na sala e esse trabalho fica meio complicado de ta fazendo uma coisa ou outra dá pra fazer, um listening, um ditado, vai eu coloco alguns números mas isso aí é MUITO de vez em quando porque senão eu não consigo cumprir a apostila... os professores das outras matérias que o digam porque a MINHA apostila de inglês ainda tem uma flexibilidade maior porque é UMA no ano... eles têm que mudar a apostila a cada dois meses... TÊM que ter cumprido aquele conteúdo porque aí muda a apostila, aí vem a apostila dois, a apostila três... o meu não, se eu quero mudar um pouquinho não tem problema porque aí lá na frente eu dou uma puxadinha a mais... ou se for necessário até substituir uma atividade por outra que seja mais rápida e deixar aquela da apostila sem fazer, não tem problema... então inglês acaba tendo uma flexibilidade nesse sentido...

((e mesmo assim tem muita coisa))

Aida: É... mas eu me preocupo, eu acho que é um conteúdo legal... eu gosto de trabalhar com a apostila $\mathrm{X}$... mas o problema é que eu acho que poderia ter MAIS aulas... pra gente poder sabe? Enunciar mais os conteúdos... porque às vezes eu tou explicando e eu percebo que aquilo tá ficando MUITO no ar... é muito fora da realidade... é uma coisa assim, como eu posso dizer, muito fora do concreto, eles não sabem lidar com aquilo como a língua portuguesa por exemplo que eles já estão acostumados... então inglês acaba sendo muito mais difícil... mas você tem que meio que tentar tampar o sol com a peneira ali e falar "bom, mais pra frente eu volto nesse conteúdo de novo e muitas vezes você acaba ficando perdida assim né? pra mim...se eu vou deixando muito de lado o cronograma depois lá na frente eu me enrolo... então a gente tem que, eu tento priorizar o aluno mas ao mesmo tempo colocar as minhas prioridades porque senão se ficar só naquele aluno ou um ou outro que segura, que trava a aula aí se não faz mais nada.

((da avaliação contínua eu acho que não vi nenhuma. Você tem como me falar qual vai ser a próxima? Eu acabei de observar a prova bimestral, aquela que o outro professor dá, ah é verdade...))

Aida: Isso. Eu aplico a mensal e a bimestral é um outro professor que aplica.

((tá, mas aquele dia você acabou aplicando))

Aida: [É eles] tiveram/foi o que eu falei lembra? Eu falei "Olha não vou falar nada porque as outras turmas não estão tendo a oportunidade de perguntar". 
((e por que isso? É sempre assim no colégio de decidir que o outro professor aplica?))

Aida: Foi...há um tempo atrás quando eu entrei aqui não era, mas foi só pra facilitar pra ser a semana de provas então aí é feito todo um horário de prova e aí a Maira coloca as provas do dia, então Matemática com Inglês... ela vai jogando uma matéria com a outra, eles acabam tendo duas provas por dia.

((tá. Então eles têm uma semana para fazerem))

Aida: [uma semana] para fazerem todas as provas e aí eles têm que se virar pra estudar a gente vai dando o apoio que pode, mas acaba ficando mesmo na mão deles porque normalmente, principalmente a quinta série... eles são MUITO dependentes... eles perguntam TUDO, eles fazem um negocinho e aí eles já vêm "tá certo?" então eles são muito dependentes... precisam muito de... da gente tá autoafirmando ali né que "ai, tá bom, tá certo", eles querem ter certeza do que estão fazendo... então na prova bimestral geralmente as notas caem MUITO porque eles ficam muito inseguros, você não tá lá, eles não podem perguntar... então é normal que na bimestral a nota dê uma caidinha...

((e a idéia de trocar de professor é pra?))

Aida: É.. uma: tem a questão de ser uma semana e de a gente ter que...né? se for só a minha prova não vai dar pra fazer tudo em uma semana e às vezes não bate do professor estar aqui naquele dia que a Maira faz o horário para ficar uma prova um pouco mais difícil com uma prova um pouco mais light... e se o professor não tá aqui aí pra não ficar essa confusão então já foi estipulado todo mundo tem a prova tal com outro professor... a princípio eles acham isso muito ruim, a quinta série, como foi a primeira prova, apesar que eles ficaram até bem na prova que você viu... mas normalmente numa prova de matemática...que foi a professora de geografia acho que aplicou, numa quinta série CHORARAM porque não deu tempo... então eles ficaram muito inseguros e desesperados pelo fato de não conseguir fazer, de não dar tempo.

((e depois o que foi feito?))

Aida: Então... depois dessa situação toda... a professora de matemática foi até a sala... devolveu as provas e eles tiveram mais um tempinho pra fazer. Isso geralmente não acontece é porque ESSA quinta série desse ano que nunca tinha visto, sabe? Esse pavor aí que foi essa prova de matemática e aí devolveu a prova e eles fizeram, mas normalmente não... Sabe é muita mudança ao mesmo tempo, até eles se adaptarem eu vejo as coisas de um outro ângulo até porque eu comecei a trabalhar com os menores, mas quando eu trabalhava só com os maiores eu também me questionava "por que cinqüenta minutos não dá?" Mas de primeira a quarta série às vezes eles ficam o dia com a prova na mão... então eles param, vão fazer o intervalo, voltam, continuam fazendo a prova... chega na quinta série tem cinqüenta minutos só então tudo é muito novo, eles não se organizam direito... isso gera uma série de sentimentos... ali que eles ficam confusos e às vezes na hora de elaborar uma prova mesmo se o professor não consegue enxergar com esses olhos porque ele não tem essa vivência de que antes eles tinham muito mais tempo pra fazer acaba tendo esses pepinos aí...e a Lorena acho que ano passado não tinha pego quinta série e esse ano pegou... então ficou meio confuso mas com certeza pro ano que vem já vai saber que nessa primeira prova tem que ser um pouco mais light em termos de número de questões, sei lá, senão eles não conseguem fazer mesmo. 


\section{Apêndice 3}

\section{Entrevista com a professora Sofia}

DIA: 16 de novembro de 2005

HORA: $14 \mathrm{~h} 00$

LOCAL: Colégio Áureo

((na verdade a gente nunca teve tempo pra conversar... há quanto tempo você está aqui?))

Sofia: cinco anos... de inglês?... eu já dou aula de inglês desde os 16 anos... já dava aulinha particular... aí eu fiz tradutor intérprete no colegial... porque eu estudava no Bandeirantes... saí do Bandeirantes fui pro Mackenzie fazer tradutor intérprete...que o Mackenzie tinha aqueles cursos técnicos profissionalizantes... aí eu fiz o primeiro ano no Bandeirantes e o segundo e terceiro no Mackenzie... (o diploma) e aí eu entrei em Letras... eu prestei e quando eu acabei entrando na USP... quando eu comecei a fazer na USP e acabei fazendo na UFMU... português e inglês... na época que eu entrei tinham acabado de mudar o campus lá pra Cidade Universitária... o prédio de Letras era no prédio de História à tarde e não tinha aula... em $75 \ldots$ $76 .$. eu já peguei toda essa parafernalha toda... e eu fiquei lá três semestres... mas eu não consegui eu não pude ficar lá porque não tinha aula... nós não tínhamos prédio... era bagunça meu pai não queria que eu fosse pra lá.... e acabei/como eu tinha prestado/no Mackenzie não consegui mais pegar... porque era muito caro.... e na UFMU foi muito bom... o curso que eu fiz... e quando eu cheguei lá todos os professores da USP estavam lá na UFMU...

((você acha que o curso de Letras foi satisfatório?))

Sofia: foi ótimo... foi... é eu tenho/sem dúvida que eu tenho cursos de inglês:: aprimoramento:: ( ) mas o curso com certeza ajuda... também ajuda no sentido pedagógico... a didática... porque Letras também tem Pedagogia... eu acho que até prepara melhor até do que Pedagogia... eu sempre gostei de História... não sabia se eu fazia Direito... mas no final eu acho que assim (eu fiz o que eu queria)... depois eu acabei a faculdade e... ((outra professora entra na sala e interrompe a entrevista))

Sofia: (...) eu comecei a dar aula em escola pública... era uma escola do Estado... ficava ali perto do Simba Safari... que hoje virou um bairro cheio de prédios... e era um mato... completamente mato... eu pegava quatro conduções pra chegar lá... e eu não prestei concurso... tinha uma tia que trabalhava lá dava aula de Matemática... saiu a professora de inglês e eu substituí... e eu acabei ficando... só que aí eu dava aula em outras escolas... (eu comecei no Salete) que hoje é a Anhembi-Morumbi... ali na Vila Prudente... que é a mesmo dono da faculdade/universidade Bandeirantes... ( )

((hoje você está aqui no Áureo e num outro né? São quantas turmas?))

Sofia: Áureo e no Maria e José... aqui são todas... mas como diminui o número de salas... ( ) eu dou dezesseis aulas aqui... dezesseis turmas não... são oito turmas... é isso? não... é mais... três do Médio:: uma quinta:: uma sexta:: duas sétimas:: e duas oitavas... tá certo, não tá? e lá no outro eu tenho doze... aí são doze turmas mesmo... aí... esse ano eu não estou no/porque eu também peguei alunos de um curso de inglês... porque uma professor entrou de licença... até final de maio eu dou aula lá no Alumni... agora ela voltou e eu fico naquela/é muito difícil... os professores não vão embora/não saem assim...é difícil sair... eu já dei aula na Cultura Inglesa... eu terminei a Cultura lá em Santo Amaro e eu fiz aqui no Madre Cabrini ((atrás do colégio))...

((Agora você trabalha em dois colégios particulares... eles têm uma/eles são muito diferentes? O que você acha de trabalhar aqui e lá? ))

Sofia: eu acho que lá/porque até o ano passado aqui estava tudo em minhas mãos... a coordenadora pedagógica era muito boa nisso... ela tem uma visão bárbara... ela tinha sabe aquela pedagogia?...

((mas aí mudou a coordenação e mudou..?))

Sofia: aí mudou a diretora... porque agora ela está fazendo aprimoramento na Itália... porque a Itália/a pedagogia é muito rica... é muito moderno tudo lá... é muito lindo lá... Estados Unidos:: Inglaterra:: a 
Itália é muito melhor pedagogicamente falando... como que a gente pode falar? O construtivismo:: tudo vem da Itália.

((você trabalha com Construtivismo...))

Sofia: é... eu gosto... porque eu trabalhei muito// eu fiz o curso na Escola Vivere.

((mas aí o projeto político-pedagógico da escola segue o Construtivismo?))

Sofia: não... não tá muito definido... então o que que a gente tava fazendo? Enquanto língua... vamos dizer o inglês/enquanto língua estrangeira moderna né... o inglês instrumental eu acho que ele bate muito bem com o Construtivismo... enfim... agora não dá pra você (fazer tudo) lindo perfeito né... não dá...pra você né... a formação:: precisa de um embasamento... fazer uma construção... precisa de alicerce...

((você diz da escola... de todos?))

Sofia: é... de todos... mas não só nessa escola... de todos... O São Tomé começou com o Construtivismo mas não é nada... não é nem uma coisa nem outra lá.. é o que eu falo não que a gente não possa aproveitar/e outra coisa eu fiquei lá três anos e aproveitei muita coisa... fiz projetos e tal:: eu cheguei a te dar a apostila da Vivere? Eu não sei se você tirou xerox:: nem lembro mais... eu não posso perder aquela apostila porque aquilo é uma construção... a gente ajudou (a montar)...

((então você continua trazendo essas idéias nas aulas aqui...dá pra você conciliar?))

Sofia: Até o ano passado eu tinha adotado o livro que é o Click-together... que é da Oxford também... ele é muito próximo do Open House:: e desses outros que estão agora saindo pela Oxford que são bárbaros:: só e nós tínhamos escolhido/o que que eu tinha feito? como eu dava aula pro/ a pré-escola aqui não tem/mas desde o fundamental $1 \ldots$ da primeira a quarta eu troquei TUDO... eu coloquei o Let's Go... por que? porque o Let's Go é neurolingüística PURA... porque aprende através da assimilação:: da repetição espaçada:: o aluno não tem que aprender tudo na vida... não precisa ficar falando traduzindo... todos aqueles textos que são do Homo Sapiens que também não é o que eles querem que passa/eu vi que realmente não era isso... a proposta do Homo Sapiens NÃO É ESSA... A proposta do Homo Sapiens É neurolingüística pura... aula dada é estudada... antes de dormir você tem que rever tudo pra você não ir dormir/ entender... tem que passar tudo pro outro lado do cérebro...senão você não entende nada...

((e o que que você acha da apostila?))

Sofia: eu acho/por exemplo... esse ano a quinta série... tudo o que foi dado até a quarta série nós estamos fazendo na quinta... então ela tá muito devagar AQUI... por que? Porque eu vim caminhando/eu peguei os quatro anos praticamente... a troca do livro/foi na segunda série que eu troquei tudo... ( )

((então qual que é a proposta da apostila do Homo Sapiens pro inglês? Qual que é o projeto deles? Ensinar língua pra quê? ))

Sofia: o curso é o inglês instrumental.

((inglês instrumental... é preparatório então?))

Sofia: inglês pra você ter conhecimento mesmo/de você ir trabalhar (num)... tanto é que eu falo pra eles... que nem esse (texto) aqui (da rede alimentar) eu poderia dar pro primeiro também ((primeiro ano - Sofia refere-se ao texto que escolheu para a prova))... eu achei interessante porque eles estão num hotel... de repente chega (pros hóspedes) de última hora chega esse... é um aviso mesmo pros hóspedes... o que que eles têm observar... sabem que eles estão lá... então está lá... hotel New York... (Mariott)... então aqui... o inglês tá bem/não tem nada de mais... é um inglês coloquial não é? é o inglês do dia-a-dia... não é o inglês cheio de/ nada shakesperiano.....muito pelo contrário né? até está mais fácil até do que português às vezes... olha... eles conseguiram fazer tudo... tá tudo evidente aqui... não tem quem não soubesse olhar aqui e... interpretar o texto em inglês e não sabe português... porque o problema maior da gente é eles não saberem INTERPRETAÇÃO... eles não querem saber de nada... não usam/eu nem sei se isso é uma deficiência no ensino... eu vejo e NÃO É da língua inglesa... é o básico:: é o lógico:: ( ) eles não fazem isso NA NOSSA LÍNGUA... que é a nossa língua mãe... eles falam e não sabem o que estão falando. 
((e isso é discutido entre os professores?))

Sofia: é... é discutido... eu sou a primeira/ eu e a professora de português nós discutimos/ batemos nisso quase toda hora... história/a prova de história... eles têm que interpretar o que está escrito ali no texto...

((então existe um trabalho coletivo aí?))

Sofia: existe... a gente tem algumas coisas assim... mas eu acho que ainda existe... apesar de dizerem que a gente não (tá muito unido) eu acho que não é tanto... eu acho que nós viemos num caminhar/mesmo esses que entraram agora:: eu sou uma pessoa que já cumprimento/tem uns que ficam mais pra trás... aqueles que não querem colocar o que querem fazer:: o que vão fazer:: gosto DEMAIS de trabalhar com a Anita... a Anita tem uma visão... ela veio comigo desde a primeira série/que quando eu entrei ela era do Fundamental I... mas depois ela passou pro Fundamental II e agora ela tá no Médio ( ) então agora pedagogicamente falando eu acho que a Anita:: a Sílvia:: elas têm assim uma/a Sílvia é a dona da escola que é a diretora pedagógica da escola... então ela tem uma visão/ela deixou trocar os livros:: ela viu tudo comigo:: ela gosta dessas coisas... desses projetos... ( ) a idéia era ter um tema/e essa coisa de cobrar também/porque quando você tá pondo num projeto/que a gente chama de projeto... porque isso aqui não é bem um projeto mas... eu já dei o encaminhamento:: passei os objetivos:: desde o começo do ano eles têm tudo isso no caderno... quais são os objetivos do projeto:: quais são os encaminhamentos/o andamento do projeto:: primeira etapa:: segunda etapa:: você não chegou a pegar tudo isso? é Construtivismo puro.

((você trabalha bastante com projetos... ainda dá pra trabalhar?))

Sofia: dá...você viu... ( ) o tema aquecimento global... global warming... aí eles/tá certo que tem muita gente/muitos pais que falam assim/como que o meu filho vai procurar na Internet um negócio desses porque ele não vai entender nada do que está lá e tal... aí vem o que o aluno também quer... porque nós não vamos traduzir tudo... nós vamos ter também que ver a mensagem/a... como que eu vou dizer? não é por assimilação... ( ) é neurolingüística pura... como que nós aprendemos a nossa língua? Como que nós aprendemos a falar português? E a gente fala rápido por que? porque a gente escuta rápido... porque a gente repete:: repete:: então nós escutamos a repetição dos nossos pais... dos nossos parentes:: do cachorro:: do gato:: eu até brinco com eles... então é como eu digo... por que que o surdo-mudo não fala? Porque ele não escuta... não é porque ele tem problemas... tem uns que têm mas a maior parte é por causa do ouvido não por causa da oralidade... porque a fala ela é inata...nós nascemos com essa fala... agora a linguagem não... é adquirida né... não... é adquirida... então é por isso que o Mowgli:: eu também falo pra eles e eles dão risada... porque se a gente (vive) com os lobos:: nós vamos falar a língua dos lobos:: se a gente nasce vive com os macacos que nem o tarzan:: nós vamos falar a língua dos macacos:: por que/porque nós estamos escutando aquilo... e eles gostam quando a gente fala isso ( ) O Mowgli fala inglês só no cinema (risos)... porque ele não fala nada né? ele gru/ ele uiva né...

((bom... essa idéia da apostila você concorda com a proposta... de trabalhar com a apostila?))

Sofia: concordo... com certeza... a apostila Homo Sapiens pro Médio/tem 3 anos que eu to aqui... mas aqui é diferente... a proposta é diferente... o conteúdo é diferente e como você vai passar pros alunos... porque o Homo Sapiens é a revisão de tudo...

((comparando o trabalho com o livro e com a apostila quais são as vantagens e quais são as desvantagens...?))

Sofia: quando eu estava indo com eles (com o livro) tava bárbaro... tinha esses projetos até ano passado... porque o Click-together tem um monte de projetos...

((gravação é interrompida momentaneamente))

Sofia: ((Sofia mostra alguns livros por ela utilizados)) então... você vai dar uma olhada e você vê que são ótimos... são bárbaros... porque tinha o texto:: eles liam:: ( ) eu nunca consegui pegar o som...

((por que não?)) 
Sofia: porque um dia tava com um:: um dia tava com o outro... a Stella:: ah... hoje não é dia... não pode... não dá... (tinha revisões... a cada duas lições tinha a revisão) e a cada bimestre tinha um projeto e eles adoravam porque tinha que apresentar...

((eles gostavam mais do livro do que da apostila na sua opinião? E você?))

Sofia: gostavam... e eu também... se bem que eu/eu acho que eu to conseguindo praticamente dar tudo né/passando por tudo... só que aí eu parei algumas coisas que eu fazia... pra fazer os projetos principalmente com a quinta série.

((e dá pra conciliar?))

Sofia: e eu tenho que seguir... aí é que está... eu tenho que seguir...e eles vêem assim/você vê que tem uns alunos ali que são devagar... o Márcio:: o Renan:: o Pedro:: o Pedro é repetente ( ) desde a primeira série eu já venho carregando isso e agora ele não podia ir pra quinta série...

((inglês não repete?))

Sofia: é a quarta matéria... se eles ficarem em três... no final do ano e a quarta (for inglês) ela vai ajudar:: vai somar:: e vai reter... mas eu não POSSO deixar o aluno por causa de inglês no final do ano... então aí que entra o Construtivismo também... por quê? o que que eu faço? naquelas médias todas que eu/que eu faço uma:: eu dou um acabamento naquilo tudo... então eu faço um trabalho tudo... eu (passo) os verbos:: o glossário:: então eu vou dando uma nota aqui outra ali mas aí eu VEJO também o que o aluno fez e não fez... no trabalho de cartolina que eles estavam montando... eu pedi o trabalho em seis... em grupo... então eles tiraram dois de média:: tinha que trazer fotografia:: eu expliquei sobre o que era...muitos alunos tiveram idéias brilhantes... (uma aluna falou) quer dizer que o papai noel daqui a pouco não vai mais estar no gelo? Já pensou o papai noel numa prancha de surf? ((Sofia refere-se ao trabalho sobre aquecimento global)) você sabe que outro dia eu fui ao shopping e quase que eu comprei... era um papai noel em cima de uma prancha de surf... só não comprei porque era muito caro... eu compraria se fosse mais barato... a Ana Carolina:: a Camila:: desde a primeira série é fantástico trabalhar com elas ((refere-se a algumas alunas))... só que numa escola com trinta:: quarenta alunos:: você não pode... você viu como ficaram as outras que brigaram comigo e disseram que eu não tinha falado?Ah mas você não falou... ( ) é uma rivalidade entre elas... na média entre tudo... quem traz o trabalho:: quem fez:: quem procurou:: quem trouxe:: eu não tenho que dar nota pra todos do grupo... ISSO É O PONTO PRIMORDIAL na minha avaliação em relação aos projetos... a esses trabalhos... que até o ano passado muitas mães vieram brigar.. eu tive que segurar as pontas... era difícil ((Sofia agora começa a tratar de um aluno especificamente))... ele não sabia nada... então ele vinha com o trabalho ele não trazia foto:: não trazia a pesquisa:: porque isso tudo faz parte também não só do aprendizado da língua inglesa... faz parte da aprendizagem do tema que nós estamos usando que é transversal... que é geografia:: história:: tudo misturado porque inglês trabalha tudo... é o COMPROMISSO... eles têm que começar a APRENDER que eles têm que ter RESPONSABILIDADE... quinta série não dá mais pra ficar brincando... eles têm isso do primário que a professora faz tudo... tudo bem eu acho isso ótimo/tudo bem... mas eu não me cobro (pra tanto) então no último bimestre ... então esse tipo de trabalho também é pra mexer um pouco com lógica:: com o discernimento deles... pra ver se eles também começam a ter um pouco de idéias sem a mão da gente... então a gente joga (pra explicar) mas é bom que eles tragam alguma coisa...com certeza eles são muito acomodados... um briga com o outro:: um xinga o outro:: não dá pra você falar pára... senta... você tem sempre que fazer uma barganha... tem que ter alguma coisa no meio que tem que mudar... então isso tudo faz parte na quinta série... agora eu acho que... essa lei de aula dada aula estudada eu acho ótimo... bate com tudo que eu acho certo porque eu estudei muito neurolingüística não só porque/pra dar aula... eu gosto dessas coisas... então além de eu fazer curso eu fui ler eu sempre fui em busca dessas coisas... então nos Estados Unidos/quando eu me formei:: eu casei:: eu fui morar lá... e eu fiz muito curso... eu não fiz propriamente a universidade... eu fiz um cursinho aqui outro cursinho ali... eu fui pra Philadelphia... eu ficava muito sozinha então eu procurei... eu queria fazer alguma coisa... ( ) aí eu voltei pro Brasil:: eu trabalhei:: eu dei aula:: ((Sofia fala um pouco sobre sua vida pessoal))

((Sofia conta um pouco da experiência de seu filho que, quando bebê e morando nos EUA, não falava absolutamente nada e depois de um bom tempo começou a falar... assistia a TV todos os dias, escutava as pessoas nas ruas e Sofia achava que ele não estava aprendendo nada)) 
Sofia: quer dizer... a gente até pode chamar isso de memória inconsciente talvez...ele nem sabia que ele sabia... é a língua adquirida (é ela que foi passada)... então é isso que eu passava na escola com trinta alunos:: quarenta alunos:: a oitava série tem quase quarenta eu acho que nem que eles escutassem UM POUCO que fossem duas horas por semana... porque ano passado a grade tinha três aulas de inglês por semana... ((Sofia acha que a atual coordenadora não dá prioridade ao inglês))

Sofia: e outra coisa... eu acho que Letras também ensina muito pra gente/você dá aula e você aprende a ser PROFESSORA... não só saber inglês... embora eu tenho estudado tudo isso aqui (durante muitos anos) eu escutei muito a coordenadora me falar que eu sou muito boa de inglês mas eu não sei dar aula... que eu não sei passar isso pros meus alunos... eu só quero comentar com você e eu já coloquei isso pra ela... se eu estou há tantos anos dando aula ( ) se você for comigo agora lá na terceira série... quarta série do primário... eles vão levantar todos da carteira e vão vir me beijar:: e vão falar teacher:: teacher:: teacher:: e vão falar em inglês isso e aquilo... pode ser que muitos/eu brigo/ às vezes eu brigo... eu acho que dá pra contornar...outras vezes/ às vezes eu falo ( ) mas eu brinco muito também... eu viro criança junto com eles...eu brigo:: depois eu vou conversar:: eu chamo:: mas eu fico sentida com algumas coisas... fico/eu fico sentida.. e eu falo pra eles... agora no segundo eu falei isso/porque tavam debochando da minha cara eu falei/ eu fico muito sentida com isso porque eu não acredito que/vocês se acham o máximo se acham amadurecidos... ( ) isso daí pra mim é a coisa mais difícil do mundo...

((Sofia refere-se à entrevista que concedeu a uma jornalista no dia do professor)):

Sofia: (e eu podia passar pra você copiar) porque a Cláudia ela foi muito gentil... nós ficamos conversando horas/primeiro ela assistiu uma aula da sétima... foi tudo sem querer... porque ela entrou na minha aula.. e aconteceu de ser... porque não tinha que ser professora de inglês... era por ser professores... (ela) queria ver a jornada do professor e eu tenho segunda e terça que eu saio daqui sempre correndo... nem almoço... já vou mastigando tomando um danone:: comendo uma maçã:: no trânsito... sexta feira foi um dia desses que caiu um helicóptero não sei aonde... não se saía daqui e eu tinha que chegar lá meio dia e meio... a coordenadora não quer saber porque que você... né::: ( )

((você gosta muito de dar aulas, né... dá pra perceber))

Sofia: eu fico muuuito... é assim... quando dizem que eu não sirvo pra ser professora... que eu não consigo... eu digo ( ) então eu acho assim é uma afronta pra mim... porque eu me dedico... o que eu fico demorando pra fazer todas essas provas...

((como que você gerencia isso, com tantas turmas?))

Sofia: é... não sei/eu acho que é uma coisa... eu admiro isso... eu não sei... eu demoro pra fazer mas eu gosto de fazer tudo limpinho arrumadinho... gosto de escrever... gosto de fazer letra caprichada:: ( )

((você tem essa motivação positiva assim, né?))

Sofia: embora em alguns lugares eles avaliam isso mas em outras não...

((avaliam de uma forma positiva e outras vezes negativa?))

Sofia: É... eu cheguei a pensar em... ai meu Deus...será que eu largo? será que eu fico só no Médio e tal? porque eu fiquei no começo/você ainda estava aqui... então sabe eu começo a ficar pressionada de uma coisa que eu perco a minha liberdade... ( ) então quando eu to muito desmotivada alguma coisa me pega...talvez eu saia daqui... você também é professor você vai saber o que que é isso.... ((Sofia agora comenta sobre a punição que levou da direção da escola num dia em que o professor do horário anterior havia deixado a sala de aula suja, inclusive com restos de cebola que só foram notados na aula de inglês. Sofia comenta que se recusou a assinar o termo da diretoria que a advertia pelo fato ocorrido))... eu levei uma advertência na sexta série porque estava suja... eu até acho que tem que ter... eu sou a primeira a achar... a catar as coisas:: não deixar/ mas o que me pegou fundo... primeiro porque não fui eu quem deixou TODA a sala suja... ( ) a sexta série está no auge dos hormônios...crescentes:: de tudo... sexuais:: criatividade:: de se auto-afirmar:: e você imagina/às vezes tem problemas psicológicos gravíssimos que a gente lida...hiperatividade:: o déficit em aprendizagem:: tem mais disso (do que a gente imagina) sabe aquele que ta sempre conversando? ( ) ele tá comigo desde a terceira série... (ele é superdotado... eu já falei pra coordenação) 
((como que a escola lida com esses alunos?))

Sofia: ( ) fica tudo junto... é tudo junto... é inclusão... você faz um curso e tem um atestado o curso é lá no SIESP... fiz dois meses eu e a professora da primeira série... a gente ia lá no SIESP... ainda tem... eu acho que vai ser até bom pra você... às vezes tem encontros de só um dia... sobre neurolingüística... um outro sobre psicologia ( ) agora eu acho que tem uma terapia... que é a TNL que é a terapia neurolingüística... que eu acho mais rápido:: mais evidente:: eu não sei se eu sou adepta a isso mas ela chama TNL... e ela/por que o que que acontece com a nerolingüística? é a parte psicológica do cérebro e a parte mecânica/é um computador... se a gente consegue pôr um disquete:: ligar:: colocar:: montar tudo:: organizar:: ou perder:: ou deletar:: não é... por que que você não pode fazer isso com a tua cabeça? porque é isso que se juntaram um psicólogo/eu não vou lembrar o nome agora... era um psicólogo e um:: digitador:: o:: o técnico em computação... eles se juntaram e descobriram a neurolingüística... aí os mais espertos como também o:: nosso amigo lá como é o nome dele aquele do computador? Bill Gates:: o que que ele fez? ele vê... pegou aquilo que ninguém entendeu e é isso que a gente tem que usar porque a inteligência é uma coisa/a inteligência é inata... tá lá tal... (você tem você não tem)... mas a competência é o único (lugar) da inteligência... se você não usa a competência atrofia tudo não é? que nem um músculo... ( )... eu queria que eles trouxessem/quando a Juliana a Daniela me falou/ ai a gente pode trazer/pode falar do papai Noel? ((no projeto sobre Global Warming)) eu falei CLARO que pode ele veio de lá... mas olhar como ela já FOI mais além... É ISSO que eu quero... o construtivismo É ISSO... então mesmo que ela tire zero numa prova eu nunca vou dar zero pra Daniela/por que? porque ela é talentosa... ela SABE TUDO... ela pode não tá indo/ela não foi bem nessa prova mas ela tem maturidade... como é que eu posso ignorar?... e aquele que/o Bruno... ele nunca faz nada... não fez o trabalho:: não veio:: eu não posso dar um dez mesmo que ele tenha tirado um dez nessa prova bimestral... isso é a avaliação construtivista... porque você um dia tá melhor outro dia você não tá:: você não tem dias que/eu pelo menos ... ah... faltou no outro dia:: não veio fazer a prova a avó morreu... como é que você pode lidar?... então se você lida/você tem que aceitar o aluno que você tem... tem problemas neurológicos:: psicológicos:: tem que tomar remédio e tal... então como que eu posso mudar o sentimento desse aluno? não dá...

((se você fosse resumir... você avalia o seu aluno pra quê?))

Sofia: ((Sofia parece não entender a pergunta que está voltada ao propósito, finalidade da sua prática avaliativa)) a nota?

((não... mas é... o que seria o avaliar né...))

Sofia: é (conceptismo) isso... ((Sofia parece referir-se ao conceito de cognitivismo/construtivismo, mas parece usar a palavra "conceptismo"))... porque a avaliação cognitiva né...veja bem... eu não vejo pela nota...de forma alguma... agora eu vejo como uma competição de mais de menos... porque aí o que que acontece/ tudo na vida da gente é uma competição né? e a gente foi criado/essa nota de ( ) é assim né?

((no caso, você avalia o aluno pra ou aprovar ou reprovar?))

Sofia: ( ) muito raramente...

((ou no caso avalia pra outro propósito... pra ajudar o aluno/olha você não foi bem nisso vamos fazer outra coisa?))

Sofia: ( ) pra incentivar né? porque eu vejo muito por aí... ( ) então por exemplo se ele tirou um e meio na prova bimestral que é peso dois com certeza não vai conseguir passar no geral... que é a junção da bimestral que é peso dois mais a média mensal e ainda tem aquela participação que eu te falei que é um ponto... que eu dou ou não dou

( ) mas aí... eu não vou negar pra você que eu olho pro aluno e falo/eu NÃO vou dar esse ponto pra ele...por que? porque aí eu tenho que ser... é IMPARCIAL... eu não posso dar um ponto pra... pra/ a Daniela fez o trabalho:: a Carol:: a Gabi:: fez o trabalho bonitinho:: arrumadinho::elas fizeram tudo ( ) com tudo o que você possa imaginar...elas já levaram pra casa até ficou aqui na feira... nem era pra aparecer mas acabou ficando de tão lindo que tava... eu posso dar a mesma nota pra aquele que (não fez)? NÃO POSSO... isso daí eu não vou dar mesmo...é isso que as mães às vezes vêm brigar...ai olha ela tirou dez... lá no grupo da Dani por exemplo você conhece mas tem outros também... eu vou dar dez pra 
aquela que veio:: fez na sala de aula TAMBÉM/não foi só em casa:: eu quero ver eles fazerem um relatório no final do trabalho que até vou pedir na próxima aula que falem sobre o trabalho que eles fizeram agora... então me fala? Quem trabalhou? Quem não trabalhou?

((é uma espécie de auto-avaliação?))

Sofia: é... eles me falam quem trouxe quem não trouxe... e eles falam mesmo (risos)... eles falam tudo... aí eles me entregam o papel... cada grupo né... ( ) e aí dá o maior rolo... o bochicho que dá... ( ) mas eu tenho que fazer isso...

((Há uma quebra na conversa aqui: pergunto se ela não quer parar para comer alguma coisa e Sofia diz para eu não ficar preocupada; Sofia comenta que também está dando aulas de Português, mas não entra em detalhes. Em seguida, em tom de desabafo, diz:))

Sofia: agora EU to aqui no seguinte sentido... eu me dôo totalmente eu acho que eu sou uma profissional muito empenhada então se eu tiver que ficar aqui eu fico... eu não vou cobrar nada... eu acho isso ridículo... tem umas coisas que eu fico muito sentida e magoada oh/eu não gosto de ( ) mas às vezes eu fico/só que eu acho que.. né? (fico) pra todos... o que tem que fazer... ta sempre educada ( ) no começo do ano eu não estava bem... ( ) assim mesmo eu devo ter faltado ao todo do ano umas quatro vezes... então eu tenho isso comigo... não é fácil levantar às cinco horas da manhã... adoro dormir...tem dias que eu venho muito mais animada...é óbvio... tem dias que eu to com vontade/não é brigar... mas eu to com vontade acho que até de contestar algumas coisas...não é... trocar idéias e tal... agora depende também do retorno senão a gente acaba perdendo a motivação... ((Sofia fala agora sobre a aula que acabou de dar no Ensino Médio)) na sala metade tava dormindo aí eu tenho que ficar chamando...tem que acordar... pedindo pra ele... então isso aí me deixa assim.../aí eu apresentei você pra Elaine:: ela tá dando aulas de inglês já:: pequenininhos... mas ela faz cultura né/ela já tá dando aula... ela lê gostoso... ela entrou agora... ela é nova... mas é bárbara.

\section{Depoimentos da professora no decorrer das aulas observadas:}

Sofia: No fundamental, a avaliação ela tem, são três atividades avaliativas de zero a nove e com mais um ponto de participação, né? E a prova bimestral que é (hum) marcada pela escola, todos sabem o dia, o horário, e é peso dois. Nós somamos essas três notas de mensal, dividimos por três e verificamos se vale (hum)... se o aluno merece o ponto ou não.

((Isso no Ensino Fundamental? Três provas por mês e uma...))

Sofia: ... e um ponto de participação. E uma bimestral, tá? A cada bimestre e... (hum) avaliando o todo, né? Toda a matéria. Porque às vezes a mensal eu faço meio separado, né? Primeiro eu dou uma matéria, dou alguma coisinha, e aí então eu avalio...

((Qual que é o peso da mensal?))

Sofia: peso 1 (um)... Divide por três, porque no final ela é uma média ponderada, então eu vou dividir tudo por três. Então a média que eu tiro das três notas da prova mensal eu divido por três e um ponto que eu vou discriminando. Por exemplo, um aluno tirou nove de média, se ele foi bem em todas as provinhas, nos trabalhos, nos projetos, em tudo o que eu faço, ele merece um ponto porque ele é bom aluno o tempo todo, ele vai com média dez na mensal... Só que aí ele tirou seis na prova bimestral, então eu multiplico o seis por dois, somo o dez que ele teve na mensal e divido por três. Aqui não (referindo-se ao Ensino Médio)... 


\section{Apêndice 4}

\section{Entrevista com a professora Beatriz}

DIA: 09 de novembro de 2005

HORA: 20h45

LOCAL: EMEF (Escola Municipal de Ensino Fundamental)

((a aula que eu estou assistindo é de inglês... você se formou em Letras - inglês?))

Beatriz: Eu sou titular de inglês... meu cargo é inglês... já estou aqui há 13 anos.... (transcrever depois essa parte) já estou indo pro décimo quarto ano... eu escolhi aqui em 1992... eu fiz Letras inglês se português, na Universidade de São Paulo, na USP... um curso muito bom...

((e aí você assume aulas aqui e numa outra escola você me falou que))

Beatriz: é... na outra escola eu sou diretora... lá eu não dou aula eu era professora também titular:: isso educação básica... pEB II que eles chamam né?... aí eu exonerei o cargo de PEB II pra ingressar como diretora também concursada em 2002... lá eu não dou aula... lá eu sou diretora... é um cargo MUITO difícil com muitas responsabilidades e toma muito tempo da gente... são oito horas de serviço mas tem dia que eu fico lá dez::doze horas...

((dez horas por dia?))

Beatriz: direto... eu já cheguei a trabalhar CATORZE horas num dia lá naquela escola...

((então... aqui é municipal e lá é estadual... a diferença eu não sei... parece que aqui só tem ensino fundamental não é isso?))

Beatriz: isso no ensino do município só existe ensino fundamental e educação infantil... e a creche... eles têm creche que é um curso que não é reconhecido assim pra escolaridade... é só pra tomar conta de criança mesmo:: as creches municipais:: depois tem o ensino de educação infantil que não tem certificação nenhuma mas é do município a responsabilidade de quatro a seis anos... obrigatório pras crianças nessa faixa etária... que é a EMEI que chama né?... e tem as escolas de ensino fundamental EMEF... que é esta daqui que é a rede municipal de ensino fundamental e aqui vai de primeira a oitava série...

((e aqui eu to assistindo aula na $6^{\mathrm{a}}$ série então aqui é seriado?))

Beatriz: é seriado... é contado ciclo mas nós continuamos seriado... nós fazemos paralelamente algumas nomenclaturas... no noturno ( ) a gente põe ciclo dois::; que é o fundamental... quarto termo... mas é oitava série.... por exemplo... não o ciclo 1 fundamental é de primeira a quarta série.... o ciclo dois é quinta sexta sétima e oitava... é de quatro em quatro... são dois ciclos de quatro séries.

((e aí eu estou estudando um pouco sobre avaliação e aqui não reprova?))

Beatriz: não... só na última série do ciclo... ou seja/ na quarta série e na oitava série...

((mas mesmo assim você continua dando avaliação?))

Beatriz: sim... eu não dou prova sem consulta/nada.... dou bastante exercício:: trabalho em grupo:: pesquisa::

((porque aí poderia até nem dar, né? por que você faz avaliação?))

Beatriz: porque o aluno precisa ta sempre estudando e ele tem que refletir... avaliar... passar o conhecimento pra uma nova situação.. por exemplo eu to trabalhando agora com perguntas e respostas... que é uma coisa DIFÍCIL pro estudante entender principalmente por causa do verbo auxiliar... olha já faz mais de um mês que eu to com esse verbo auxiliar e eles não entendem...porque é uma coisa que não 
existe em língua portuguesa né? mas perguntar e responder todo mundo fica perguntando toda hora... se você pergunta em português eles não têm problema nenhum/agora se começa tentar fazer a correspondência na tradução:: eles se perdem no verbo auxiliar... aí eu fico mostrando que não tem como traduzir... eu ponho a tradução na lousa eu ponho a flechinha/essa palavra é essa palavra... essa é essa... pra mostrar... ah...aí eles vão entendendo... tem alguns que já aprenderam já estão adiante... mas uns que ficam só brincando não tá conseguindo acompanhar...

((então você faz avaliação mais no sentido/pra...?))

Beatriz: pra que eles possam estar transferindo a situação.. então a gente estudou pergunta e resposta e agora eu to mudando as perguntas mas sempre com o verbo auxiliar no meio... do presente simples...

((e aí... não sei mas... os outros professores continuam fazendo avaliação... apesar de não reprovar mais?))

Beatriz: continuam fazendo... tem alguns que dão prova sem consulta... eu acredito que sem consulta não adianta nada porque se ele vai memorizar ele vai esquecer....eu não quero que ele memorize/eu quero que ele SAIBA fazer... por exemplo eu faço uma palavra cruzada pra eles fazerem do dia das bruxas... nós estudamos o vocabulário primeiro... as palavras... eu mostro umas fichinhas de cartolina com uns desenhos e vou falando o nome de cada um dos personagens... depois que falamos eles vão anotar as palavras... nós vamos escrever as palavras... aí nós vamos ler o que eles escreveram... porque muitos copiam errado também.. porque muitos da $6^{\mathrm{a}}$ série não têm uma alfabetização muito consolidada:: e só na cópia eles já cometem erros... na palavra cruzada eles falam... professora tá faltando quadradrinho... tá faltando quadradrinho... eu falo/não:: eu fiz o check-up igual ao McDonalds... duplamente checado... não falta nenhum quadradrinho... será que você não copiou errado no seu caderno? aí eu chego lá/posso olhar o seu carderno pra ver como você copiou? Dito e feito...olha copiou errado... porque não cabe no quadradinho... aí eu vou lá e falo essa palavra é assim que se escreve... aí ele arruma no caderno dele e escreve certo lá...

((agora... eu só assisti duas aulas...a primeira aula foi conteúdo né? e na segunda foi uma avaliação))

Beatriz: é... eu dei a avaliação... e eu não ia explicar nada eu tinha falado pra eles...

((eles ficaram mais quietos... foi por causa da avaliação?))

Beatriz: foi... foi por causa da avaliação... porque tem professor que pega pesado na avaliação... então eles já/

((então, mas aí o aluno sabe que não reprova....))

Beatriz: sabe...

((e mesmo assim ele leva a sério...))

Beatriz: mas é que nós falamos pra eles...a gente fala muito/EU pelo menos falo bastante... se você não fizer as atividades desta série como que você vai acompanhar na série seguinte? Vai ficar um pouco mais difícil:: vai tem mais conteúdo:: outras coisas novas:: tem coisa que você vai ver lá na frente que vai depender disso daqui que eu to falando... e se você não chegar na oitava série e não acompanhar você vai ficar tirando diploma de oitava série... vai ficar lá reprovando... reprovando... reprovando... reprovando.. que horas que você vai acabar o seu curso? Então a gente começa a pensar em dar uma pressão neles psicologicamente pra eles verem o futuro lá na frente... na sétima série é uma BELEZA porque a sétima série já é o ano seguinte...

((porque aí eles sabem que podem reprovar na oitava... é isso? E tem muita reprovação na oitava, tipo é comum... ))

Beatriz: tem... acontece... esse ano mesmo nós temos no período da manhã alunos que reprovaram o ano passado e tão correndo o risco de reprovarem de novo... já tão chamando os pais pra conversar...

((bom... não reprova... e aí se o professor percebe que o aluno tem uma dificuldade... por exemplo na sexta série tem alguns... aquele que sente no fundo...)) 
Beatriz: O Ademar... por exemplo.... tem MUITA dificuldade... e ele gosta de mudar de lugar o tempo inteiro...

((e o que que se faz com eles... porque eles têm dificuldade... tem recuperação?))

Beatriz: tem recuperação...

((e como que é... todo bimestre?))

Beatriz: é... o próprio professor dá outras avaliações né... e quando o aluno está com MUITA dificuldade tem aquela sala de apoio pedagógico... SAP... alguns alunos do ensino fundamental agora de quinta a oitava tão podendo participar também dessa sala de apoio pedagógico.

((é um horário extra classe?))

Beatriz: é um horário extra classe... tá funcionando bastante pras crianças de primeira a quarta né? eles vêm pela manhã pra ter um reforço escolar mais individualizado...

((mas é o mesmo professor que dá?))

Beatriz: não.. é um professor contratado especialmente pra isso... e agora tem alguns alunos do fundamental que também estão podendo participar/esses que estão com dificuldade de alfabetização por exemplo:: eles estão já freqüentando essas salas...

((e aí independe da faixa etária?))

Beatriz: independe... mas nós já tivemos alunos que tiveram essa oportunidade e resolveram começar a faltar... chamaram a família pra saber por que a família não justificou... e o aluno continuou faltando e acabou até reprovando de ano...e NÃO VEIO nesse reforço de apoio pedagógico.

((o aluno é convocado/é convidado?))

Beatriz: é convocado...tem um papel convocando com o dia e o horário que ele vai ter essa aula a mais... toda semana... se ele estuda à tarde ele vem de manhã.

((mas isso é só na escola municipal?))

Beatriz: só na municipal... na estadual existe um PROJETO de recuperação de reforço:: incluído na sexta aula da jornada do aluno... ele tem que ficar na escola e ele é convocado também por escrito... e ao invés de ir embora (como os outros alunos) ele fica nessa aula de reforço... porque a grade curricular no ensino estadual esse ano são vinte e:: seis aulas... não... (vinte e cinco...vinte e sete... são vinte e sete aulas... sobram três aulas... duas são pra reforço... uma de português e uma de matemática e uma é projeto da hora da leitura... são professores contratados pra darem essas aulas... mas tem que ser na SEXTA aula do aluno... eu acho TERRÍVEL colocar esse horário na sexta aula porque o aluno já está mais cansado naquele dia... não tá funcionando muito legal não... e tem uns alunos que fogem... escapam... vão embora... vai pra outra sala que não tem aula de reforço...

((mas engraçado... eu vi mesmo que eles ficaram mais quietos naquele dia...))

Beatriz: é a avaliação... eu dou nota de caderno também... eu passo dando visto... aquele dia da avaliação não/mas outro dia/eu tenho uma página pra cada sala...aqui por exemplo na $6^{\mathrm{a}} \mathrm{A}$ nesse $4^{\circ}$ bimestre aqui nós já estamos na quarta atividade... o Ademar ó...((Beatriz mostra lista para mim)) não fez nenhuma apesar de estar na classe... o Edson fez duas... deixou duas sem fazer... isso é o visto do caderno... ao passo que você vê que tem outros que fazem tudo ó ... então bimestralmente eu vou marcando e depois eu faço uma média... média de caderno... no outro bimestre eu já fechei ( ) aqui ó... terceiro bimestre:: no caderno:: o Ademar chegou a fazer metade das atividades... então quem tem (menos) uma até metade fica com $\mathrm{S}$ de caderno

((que é satisfatório?)) 
Beatriz: que é satisfatório... quem tem menos da metade como é o caso da Beatriz... fica com MS... eu só vou dar nota Beatriz se ele tiver completo... isso pro caderno... faltou uma só ele fica com S... isso é bimestral... olha o segundo bimestre deles... ó o Ademar aqui de novo... tava com MS de caderno... aqui é um termômetro... o Edson não estava aqui ainda... ele veio no segundo semestre... você vê/um:: dois:: três:: quatro:: olha quantos Ps... bastante né? então a parte do caderno é uma atividade que a MAIORIA tem em dia...

((agora além do caderno/tira a média do caderno e aí...))

Beatriz: olha nesse bimestre que eu dei mais avaliações de caderno ainda... o Ademar tava um pouquinho melhor ó... ((Beatriz mostra notas))...

((quer dizer não é toda aula.... é pra verificar se eles estão anotando:: copiando:: e seguindo a aula))

Beatriz: isso... isso... porque como a gente não tem o livro e nem caderno eu não tenho como tá avaliando... então eu tenho o diário deles aqui mas eu costumo marcar as atividades aqui... trabalho em grupo:: trabalho em dupla:: as frases:: e vou pondo aqui... exercício:: trabalho individual:: não é? nota de caderno:: auto-avaliação:: que é uma atividade que eu desenvolvo com eles que tem um ROTEIRO de perguntas:: que eles vão se dando uma pontuação...

((isso todo bimestre?))

Beatriz: todo bimestre... eu chamo de cidadania...

((todos os professores usam?))

Beatriz: não... olha... eu só tenho essa folha clarinha aqui se você quiser da pra ler...pode ficar com essa... acabaram as minhas cópias eu preciso fazer outro extenso... e aqui é onde eles respondem...

((o que que eles acham disso?))

Beatriz: tem alguns que falam... outra vez professora? que nós combinamos no início do ano que essa auto-avaliação que é CIDADANIA... que são os seus direitos e os seus DEVERES principalmente é feito por bimestre... então de manhã são quatro bimestres e no noturno são só dois... que é semestral... as perguntas são essas ó... freqüências às aulas... utiliza somente o limite permitido de cinco por cento?... então se ele utiliza ele vai se dar nota CINCO... se ele passa do limite das faltas... precisa compensação de ausência ele vai se dar nota dois...e se aquele aluno que falta muito além da compensação de ausência... ele tá bem estourado em falta... ele vai se dar nota zero porque ele nunca tá presente...aí na pergunta dois... o caderno contém as anotações BÁSICAS... resumos:: tabelas:: exemplos:: textos:: diálogos:: e eu falo pra eles... toda vez que eu vou fechar a MÉDIA do bimestre é pelo CADERNO que eu faço a média... se eu to na dúvida se o aluno merece nota $\mathrm{S}$ ou nota Beatriz na média do semestre... eu olho o caderno porque é o nosso único instrumento mesmo do dia-a-dia... porque não tem livro... pelo fato de não ter ...PNLD né? o programa nacional do livro didático... PNLD... o governo federal que fez esse programa pra distribuir os livros de português:: matemática:: história:: geografia:: e ciências pras escolas fundamentais... e agora eles estão fazendo pro ensino médio pra usarem o ano que vem... de português... e INGLÊS é esquecido totalmente...

((mas é uma disciplina ou prática...))

Beatriz: É uma disciplina...é disciplina do currículo... tá na grade curricular... na parte diversificada mas faz parte do currículo...é um componente obrigatório... e o professor tem que ser licenciado em inglês... então como não tem livro eu me apego no caderno... por isso que a gente faz todo esse trabalho com o caderno...( ) aí tem essas outras questões que você pode ler depois... permanecer na sala... evita sair da sala pra beber água:: ir ao banheiro:: telefonar:: etc? noturno tem muito disso... ah... preciso telefonar/preciso telefonar... diurno tem menos... mas alguns pedem pra telefonar também... agora ir no banheiro e beber água:: é direto... então quem evita sair:: nota maior... respeita aos colegas? a famosa brincadeira:: discussão:: apelido:: atenção e concentração:: exercício de pronúncia:: é uma coisa DIFÍCIL a gente conseguir atenção deles pra pelo menos ta lendo... pronunciando... 
((que que são esses exercícios?))

Beatriz: são as palavras:: as frases:: eu quero que eles lêem...

((aí você lê e eles repetem... é isso?))

Beatriz: isso... nas salas mais avançadas por exemplo sétima e oitava séries eu trabalho com diálogo... eles encenam o diálogo... primeiro eles trabalham a pronúncia depois ele vão lá e interpretam o diálogo...

((você comentou comigo que a sétima era melhor? A sexta é mais difícil?))

Beatriz: é... é bem melhor... sétima e oitava... sexta série é bem mais difícil.... é a idade deles mesmo...eles já estão deixando de ser crianças ainda não são bem adolescentes... é uma idade difícil... não tem muita MATURIDADE e muitos não têm o conhecimento suficiente pra você ir adiante... então você tem que dar coisa muito básica... é difícil... atividades mimeografadas que eu faço exercícios diversos né? ultimamente eu não to tendo muito tempo pra mimeografar... eu tenho feito pra eles copiarem da lousa mesmo e responderem... mas algumas coisas eu tenho feito mimeografada... pra ler um texto:: pra traduzir:: pra ter um vocabulário:: pra evitar fica perdendo tempo de pesquisar no dicionário que demora muito:: eu já passo tudo na folha...

((eles têm dicionário?))

Beatriz: eu levo emprestado da sala de leitura pra usar na sala... tem vinte dicionários que eu levo e trabalham em dupla... e atividade em dupla ou em grupo... ((retomando perguntas do roteiro da autoavaliação)) você faz SUA PARTE e não coloca apenas o seu nome no trabalho deixando aos outros toda a tarefa? Isso é muito típico né... não faz NADA::

((de onde você tirou essa idéia...?))

Beatriz: isso aqui eu peguei de um livro que tinha algumas idéias ( ) é sobre avaliação mesmo... eu não lembro qual era o autor... eu fiz umas adaptações pro inglês... esse tipo de pontuação eu peguei a idéia de lá... eles trabalhavam com sempre... às vezes... e nunca... aí eu transformei em número... e desses números eu fiz uma tabela pra virar pontos e virar letras depois...

((quer dizer... isso tudo o governo não te obriga a fazer... não é...))

Beatriz: não... eu to fazendo isso daqui porque eu quero ver se CRIA uma consciência pra melhorar enquanto estudante... pra eles CUMPRIREM os deveres deles... porque se você faz uma auto-avaliação e não dá um roteiro... eles vão escrever SÓ um monte de bobagens... por exemplo aqui... comentários... por que que você merece ficar com essa nota?... tem uns que escrevem assim... porque eu sou maravilhoso:: $(($ risos $))$

((mas a maioria se dá a nota que você considera justa?))

Beatriz: a maioria dá... (eu falo) eu acho que você ainda não está merecendo esta nota... porque nos itens tais:: tais:: tais:: você ainda não está tão bem... você ainda não tá tudo isso... eu escrevo assim com jeito pra não magoar ninguém né? deixa eu pegar algumas de uma outra série... da quinta série aqui... tem a auto-avaliação do quarto bimestre ainda... deixa eu pegar aqui... ó... aqui um exemplo.... eu mereço esta nota porque participo das aulas:: faço de tudo pra deixar o meu caderno organizado:: e adoro MUITO as aulas de inglês...

((e é mesmo?))

Beatriz: é... geralmente é... aí eu coloco uma observação ó... nesse caso eu pus assim... parabéns... você é um ótimo estudante de inglês... continue assim...

Beatriz: ((e aí você entrega pra eles?))

Beatriz: isso 
((e aí eles entregam de volta pra você?))

Beatriz: ó... esse aqui/o Ismael... ele estudava nessa sexta A da manhã e passou pra noite... melhorei muito desde eu ter de sair da parte da manhã... aí eu pus... concordo com você... mas você pode melhorar ainda mais... ESTUDE e verá... parabéns... eu já disse pra ele que realmente a mudança foi MUITO grande... ele era terrível de manhã... do tipo assim daquele que senta perto da porta... o Cleiderman... não pára quieto... mais ou menos daquele estilo... não parava no lugar:: só conversando:: não fazia:: não tinha caderno::

((e por que que será que ele mudou?))

Beatriz: o grupo leva mais a sério...( ) deixa eu ver aqui mais um... porque eu tento me esforço...em vez de esforçar né? (eu pus) parabéns... você está estudando bastante inglês... a Edilaine... realmente ela tá MELHORANDO... ((Beatriz, após ter explicado o funcionamento da auto-avaliação, mostra algumas atividades que já desenvolveu com suas turmas))... ó... aqui é uma palavrinha cruzada... essas são as atividades mimeografadas... essa aqui por exemplo... foi um trabalho com texto... tinha as frases:: eles tinham que fazer a tradução:: e eu já passei o vocabulário porque senão eles levariam muito tempo pra pesquisar mas já ensinei como se usa o dicionário... é só pra ir agilizando né? ...aí tem a segunda parte...pegar as mesmas frases em inglês e separar pelos personagens... são frases de cada um dos três personagens... só que antes de fazer a atividade eu mostrei figurar... eu arrumei figuras de mulher:: de homem:: uma mais nova:: uma de meia-idade:: um mais velho:: e arrumei figuras referentes aos empregos de cada um... o hospital:: o caminhão:: isso mostrando pra eles terem uma idéia do texto antes de trabalhar com a parte escrita...eu mostrei as figuras:: falei:: depois entreguei a folha:: e no final de tudo eu pus as frases na lousa pra nós lermos.

(( isso é na sexta?))

Beatriz: é... de manhã eu também fiz essa mesma atividade... tanto de manhã quanto à noite.

((esse foi o conteúdo já do...))

Beatriz: (do quarto bimestre)... trabalhamos também com presente simples... aqui tem o verbo to be e mais outros verbos... o verbo trabalhar:: falar:: viajar:: ter:: comentar:: vestir::

((então... esse conteúdo aí você que define?))

Beatriz: é... nós decidimos em conjunto aqui na escola... o que nós achamos mais convenientes estar passando pros alunos.. eu faço assim uma programação de tempos BÁSICOS pra quinta:: sexta:: sétima e oitava... então em conjunto com essa professora de inglês a gente dividiu o que era mais interessante ta passando...então na sexta série pra avaliar o presente simples... tudo o que é possível com o tempo presente... então profissões:: trabalho:: as várias situações... nós fizemos o personagem misterioso:: eu mostrei a figura do Garfield:: e eles tinham que (montar) uma série de frases que eram pra descobrir que o personagem era o Garfield... eh... dorme de manhã:: come lasanha... mora na casa do John... detesta a segunda-feira... então nós lemos as frases:: traduzimos:: e aí eles concluíram que o personagem era o Garfield aí eu mostrei a figura... olha o Garfield aqui... tudo presente simples... aí fiz com outros personagens... do Batman:: do Super-Homem... é... o conteúdo a gente que define... a gente escolhe o tempo verbal e vamos trabalhando o que pode causar interesse pra eles né...

((a respeito da conciliação do trabalho e da vida pessoal, como você concilia, arranja tempo pra fazer as atividades?))

Beatriz: sábado... domingo... feriado... e essa hora aula que eu tenho aqui...

((e eu ainda te atrapalhando...))

Beatriz: porque é uma coisa que sabe/ dá trabalho... eu tenho dez turmas... mas eu não me sinto bem fazendo qualquer coisa sabe? tem que preparar... olha aqui eu tava preparando uma atividade e nem deu tempo... eu ia passar no extenso... até to com o extenso aqui mas eu já passei algumas coisas já na lousa pra eles... adivinhações...perguntas e respostas de um jeito diferente pra associar... olha... ((Beatriz mostra exemplos pra mim)) how do you like school?... closed... como você gosta da escola? fechada... (risos) 
essa era pra sexta série também...no primeiro semestre eu trabalhei com a sexta série o jogo da memória... essa sexta série A... era um trabalho em grupo... pega uma cartolina e centímetros e eles tinham que colocar o objeto com uma cor... então por exemplo uma laranja:: uma maçã:: e colorir... no outro quadradinho eles tinham que escrever a cor e o nome do objeto... pra usar a inversão do adjetivo em relação ao substantivo... red apple... por exemplo... maça vermelha... black cat... gato preto... então a gente já tinha um (certo) vocabulário... e aí ou desenhava ou achava as figuras...e depois tinha que escrever em inglês o que que representava aquela figura por cor... e aí era um jogo da memória... eles embaralhavam e jogavam... leva quatro aulas... confecção e depois jogar... o mais difícil é lembrarem de trazer o material... aí pede socorro lá na secretaria/você pode me arrumar umas cartolinas?

$((\mathrm{e}$ tem?))

Beatriz: sempre tem... eles emprestam...

((você acha que nesse sentido a escola municipal é mais organizada que a estadual?))

Beatriz: não... não é questão de ser mais organizada... é a questão do tamanho da escola... porque às vezes você até quer ajudar o aluno dá materiais mas se a sua escola tem muitos alunos você não pode ficar fornecendo material toda hora.

((aqui tem quantos alunos?))

Beatriz: aqui nós temos dez salas... é uma escola pequena...lá onde eu trabalho são 23 classes de manhã.. 23 à tarde e... 15 à noite... mais de 2.000 alunos... aqui deve chegar uns 1.000 alunos... manhã... tarde e noite... dá pra gerenciar bem melhor.

((só mais uma coisa... qual que é a sua maior dificuldade?))

Beatriz: a maior dificuldade é conseguir a disciplina deles... mesmo que a gente traga uma atividade que é interessante... com figura:: com isso com aquilo:: tem uns que só querem brincar... e eles aí não se despertam... tem sala como essa daí que eu não consigo fazer nada... mesmo levando coisas... você trabalha com dificuldade... ah... mas eu não desisto uma hora dá certo... 